\title{
Money and mobility : migration and remittances
}

Citation for published version (APA):

Siegel, M. (2010). Money and mobility : migration and remittances. [Doctoral Thesis, Maastricht University]. Boekenplan. https://doi.org/10.26481/dis.20100521ms

Document status and date:

Published: 01/01/2010

DOI:

10.26481/dis.20100521ms

Document Version:

Publisher's PDF, also known as Version of record

\section{Please check the document version of this publication:}

- A submitted manuscript is the version of the article upon submission and before peer-review. There can be important differences between the submitted version and the official published version of record.

People interested in the research are advised to contact the author for the final version of the publication, or visit the DOI to the publisher's website.

- The final author version and the galley proof are versions of the publication after peer review.

- The final published version features the final layout of the paper including the volume, issue and page numbers.

Link to publication

\footnotetext{
General rights rights.

- You may freely distribute the URL identifying the publication in the public portal. please follow below link for the End User Agreement:

www.umlib.nl/taverne-license

Take down policy

If you believe that this document breaches copyright please contact us at:

repository@maastrichtuniversity.nl

providing details and we will investigate your claim.
}

Copyright and moral rights for the publications made accessible in the public portal are retained by the authors and/or other copyright owners and it is a condition of accessing publications that users recognise and abide by the legal requirements associated with these

- Users may download and print one copy of any publication from the public portal for the purpose of private study or research.

- You may not further distribute the material or use it for any profit-making activity or commercial gain

If the publication is distributed under the terms of Article $25 \mathrm{fa}$ of the Dutch Copyright Act, indicated by the "Taverne" license above, 


\section{Money and Mobility: Migration and Remittances}


C2010 Melissa Siegel

All rights reserved. No part of this publication may be reproduced, stored in a retrieval system, or transmitted in any form, or by any means, electronic, mechanical, photocopying, recording or otherwise, without the prior permission in writing, from the author.

ISBN 9789086661398

Cover picture and illustrations for each chapter by Ian Burkard Published by Boekenplan, Maastricht 


\title{
Money and Mobility: Migration and Remittances
}

\author{
PROEFSCHRIFT
}

To obtain the degree of Doctor at Maastricht University, on the authority of the Rector Magnificus Prof. dr. G.P.M.F. Mols in accordance with the decision of the Board of Deans to be defended in public on 21 May 2010, at 12:00 hours.

by

Melissa Siegel 
Promoter:

Prof. Dr. C. De Neubourg

Assessment Committee: Prof. Dr. J. Muysken (chairman)

Dr. H. de Haas (Oxford University)

Dr. K. Koser (Geneva Centre for Security Policy)

Prof. Dr. V. Mazzucato

Prof. Dr. H. Schneider 


\section{Acknowledgements}

This dissertation is the result of the support of so many, all of whom I will not even attempt to mention. First and foremost, I would like to thank my family for all of their love and support during my extended education. To my parents (Jeff and Terri Siegel) for all that they have given me also my thanks to my mom for proof reading parts of this work. To my brothers (Joe and Ben), for coming to support me in Europe and for doing what brothers do best, always keeping me in check.

To Mormor and Morfar, I appreciate the support for my first real taste of Europe, which made me fall in love with this continent and for wonderful Swedish country side moments, perfect for writing. A special appreciation goes to my Morfar who always truly understands what I do.

To my loving Floalicious for being understanding, kind, loving, considerate and many other adjectives through my many stressed days (and for reading my entire dissertation)....now it is your turn.

To Chris ( my promoter, co-author, mentor, boss and so much more), I cannot thank you enough for having confidence in me and supporting me all the way and giving me the freedom to research what interested me and promoting me through my career. To the School of Governance more generally (Franziska, Mindel, Annemarie and the ladies down stairs), I appreciate you putting up with my hyperactivity and often overenthusiastic behaviour.

To the fist cohort (you know who you are), thank you for making this $\mathrm{PhD}$ experience one I will always remember and friendships for a lifetime. Jessica, thank you for all of the support through the PhD, the much joint work and many conferences spent together and for being my hero. No one can combine work and family like you. Britta, you had to share an office, house, runs and so many more things with me. Thank you for always being a great example in work and sport. To the famous "governance girls" (Denisa, Zina, Lina, Paty, Jessica, Britta, Frieda, Metka and many more), you made this $\mathrm{PhD}$ process more fun and memorable than I could have ever hoped. Thank you to all of the amazing governance friends for all of the wonderful memories, for fantastic destination weddings in Mexico (and honeymoon with my favourite Mexicans) and Egypt, for writing camps, races and travelling around the world.

To the other people that had to put up with working with me....Matthias Lücke, thank you for first introducing me to Moldova and working together with me.

To Stephanie Wheeler (an old friend and life path parallel), who made me go down a path I did not want to travel, but from which I gained much knowledge. Thank 
you to Britta and Metka who put up with writing with me, when it wasn't even for my $\mathrm{PhD}$. To Sarah Hays for reading my drafts and not only being a fantastic friend and supporter since before my PhD days but also now as a colleague and to Josh for always supporting my continued schooling and allowing my constant crazy visits.

To the many people who I made suffer through sport along the way...Pascal, Robert, Eze (thanks for teaching me how to play squash) and Bas, thank you for tolerating forced running (and other sporting) as well as to all the other people who I managed to coerce into moving more than they wanted to.

Thank you to the many people from my Utrecht days (Groote Crew, Despi, Alexey, Gar Yein, Hannah, Ana, etc.) you knew me when this all started and my struggle to get to this point.

To my fantastic and numerous flatmates (Britta, Metka, Frieda, Ana, Christiane, Flo and many more), living with you and the constant flow of people through the house made everything more enjoyable.

Thank you to Sonja Fransen for the Dutch translation, I couldn't have done it without you. To my long time friend, Ian Burkard, I am so happy that I was able to have your lovely illustrations in my PhD. Thank you to Michaella for editing parts of this dissertation.

Thank you to my reading committee (Joan Muysken, Hildegard Schneider, Valentina Mazzucato, Hein de Haas and Khalid Koser) who not only had to read my dissertation but whom also had to work with me often.

To all of the other family and friends in the United States and the rest of the world, you mean the world to me and I couldn't have done this without you. 


\section{TABLE OF CONTENTS}

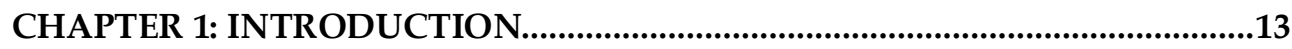

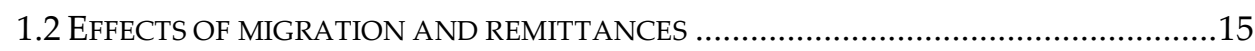

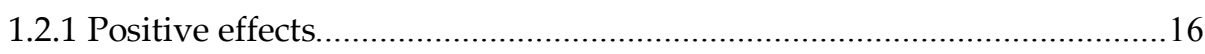

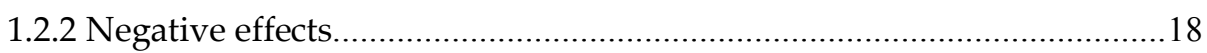

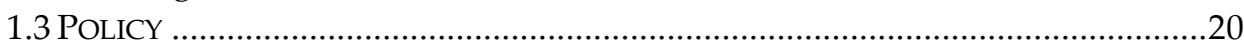

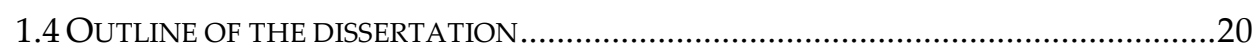

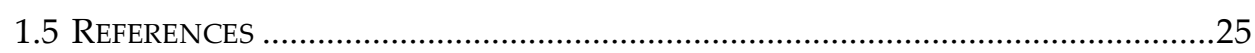

CHAPTER 2: A LIVELIHOOD PORTFOLIO THEORY OF MIGRATION...........28

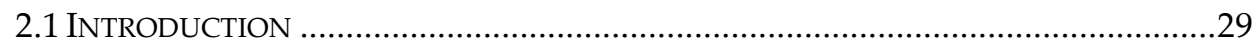

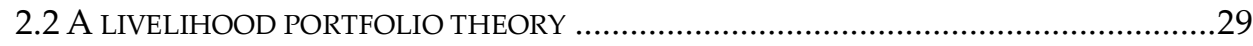

2.2.1 Livelihood portfolio decisions within the welfare pentagon....................29

2.2.2 Migration as a livelihood portfolio decision ..............................................34

2.2.4 The receiving country welfare pentagon ................................................... 38

2.3 EMPIRICAL EXPLORATION OF THE LIVELIHOOD PORTFOLIO THEORY OF MIGRATION:

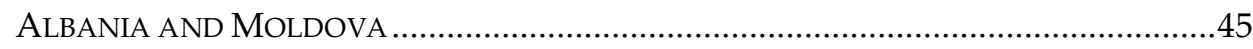

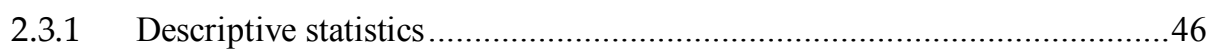

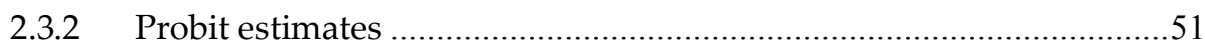

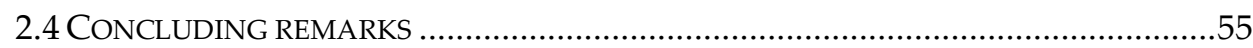

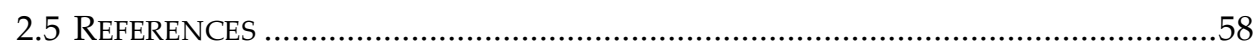

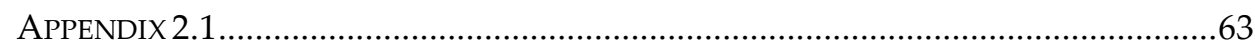

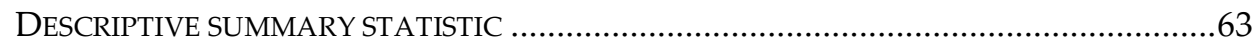

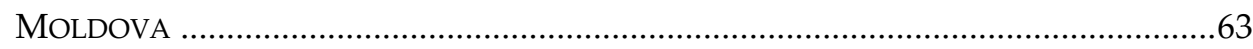

CHAPTER 3: A CRITICAL DISCUSSION OF THE MOTIVATIONS TO REMIT

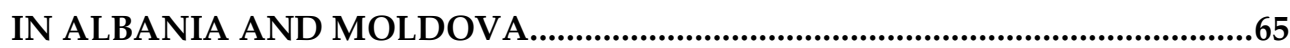

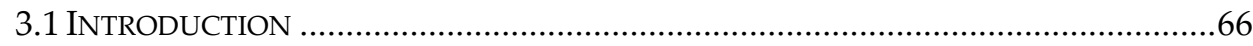

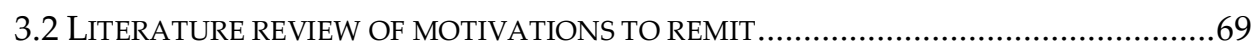

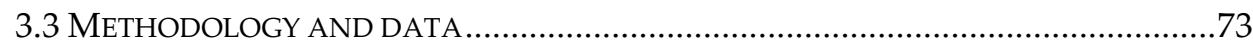

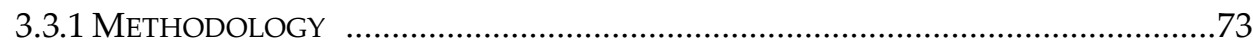

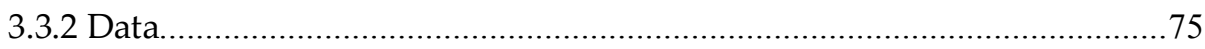

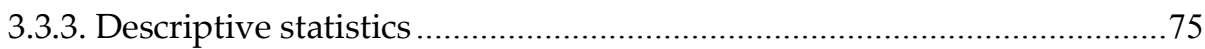

3.4 EMPIRICAL MOTIVATIONS TO REMIT IN ALBANIA AND MOLDOVA ........................79

3.4.1 Measuring altruism and self-insurance (of the migrant) motives in

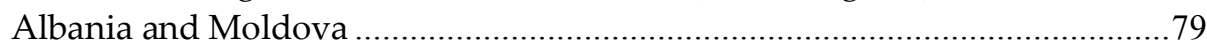

3.4.2 Measuring the bequest and co-insurance motive in Albania.....................85

3.4.3 Measuring loan repayment in Moldova.................................................90

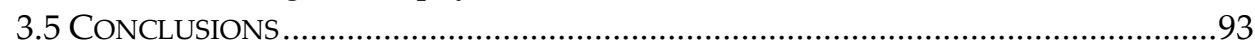

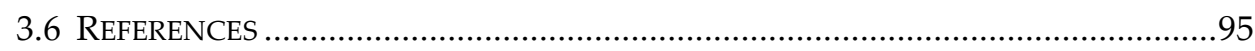

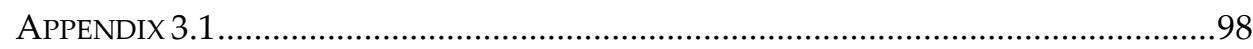




\section{CHAPTER 4: WHAT DETERMINES THE CHOICE OF TRANSFER CHANNEL}

FOR MIGRANT REMITTANCES? THE CASE OF MOLDOVA …………...........100

4.2 LABOR MIGRATION AND REMITTANCES IN MOLDOVA SINCE 1999 ......................103

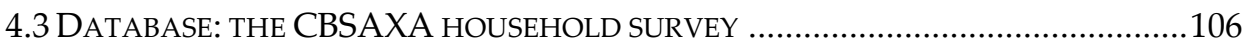

4.4 TRANSFER CHANNEL CHOICE, MIGRANT AND HOUSEHOLDS CHARACTERISTICS .108

4.5 ECONOMETRIC MODEL ........................................................................113

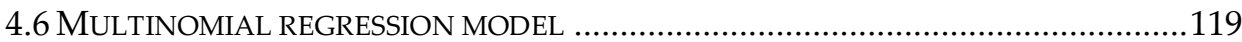

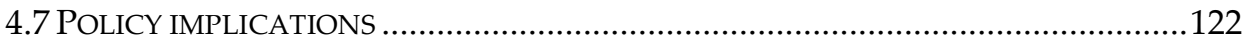

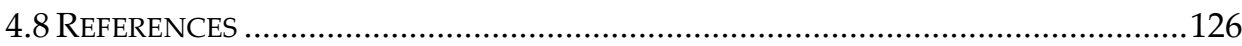

CHAPTER 5: IMMIGRANT INTEGRATION AND REMITTANCE CHANNEL

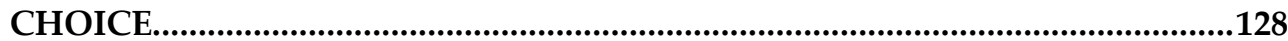

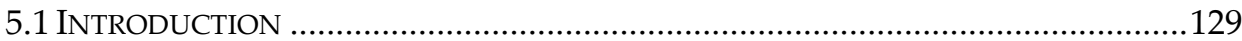

5.2 IMMIGRATION AND REMITTANCES IN THE NETHERLANDS ................................131

5.3 AN INDEX OF IMMIGRANT INTEGRATION IN THE NETHERLANDS ........................135

5.4 REMITTANCE CHANNEL CHOICE ................................................................... 140

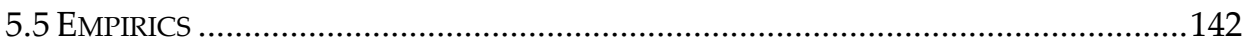

5.5.1 Formal vs. informal remittances ....................................................... 143

5.5.2 Bank vs. MTO remittances .............................................................. 145

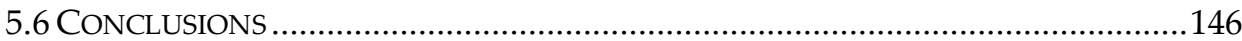

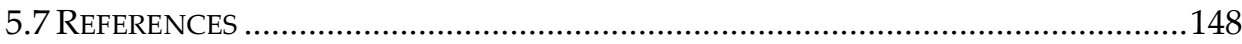

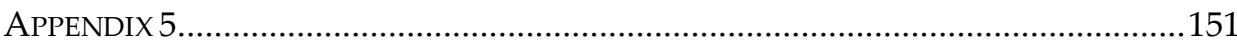

CHAPTER 6: MIGRATION EFFECTS ON HEALTH EXPENDITURE: THE

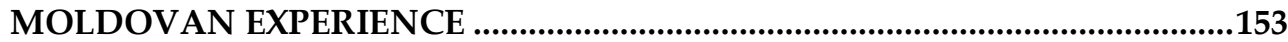

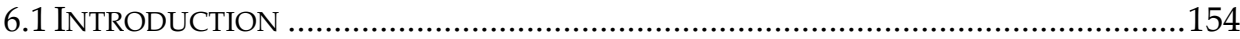

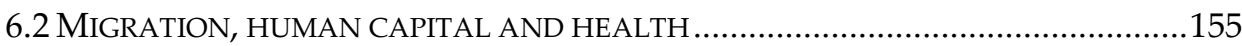

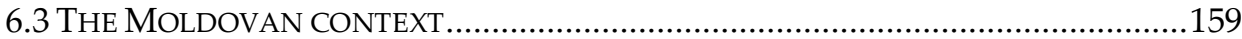

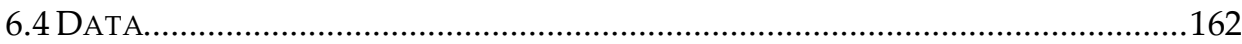

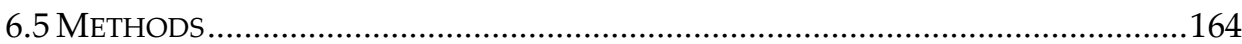

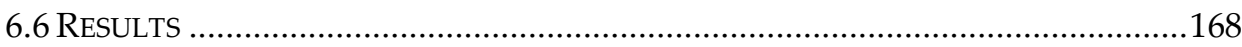

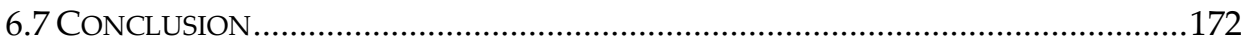

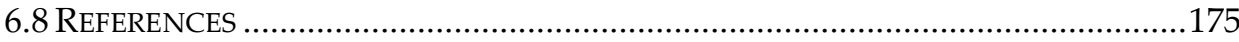

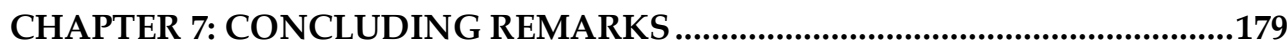

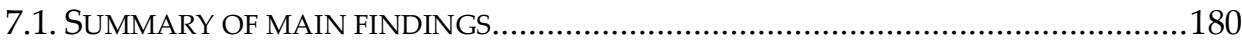

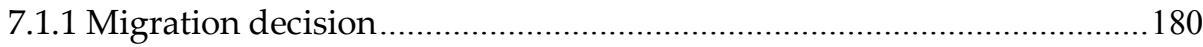

7.1.2 Remittance decision (in Albania and Moldova) .................................. 182

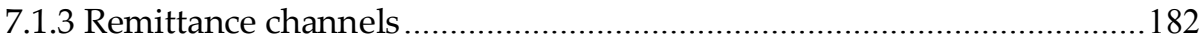

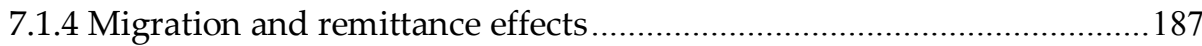

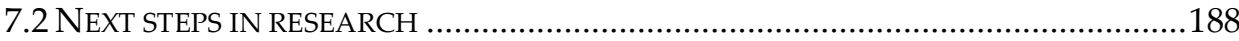


7.2.1 Migration. 188

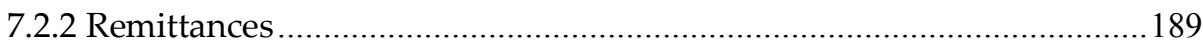

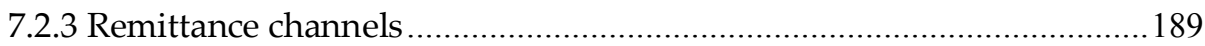

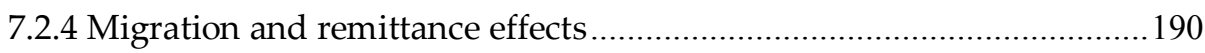

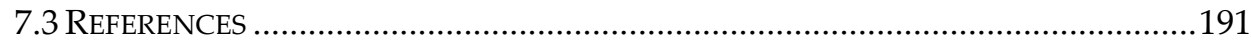




\section{List of tables}

Table 2.1 Consumption smoothing channels for migration decision to move Table 2.2 Differences between households with migrants and without migrants: Control variables

Table 2.3 Differences between households with migrants and without migrants: Family institutions

Table 2.4 Differences between households with migrants and without migrants: Market institutions

Table 2.5 Differences between households with migrants and without migrants: Social network institutions

Table 2.6 Differences between households with migrants and without migrants: Membership association institutions

Table 2.7 Differences between households with migrants and without migrants: Public authority institutions

Table 2.8 Probit analysis estimating the probability of households to not have a migrant

Table 2.9 Probit analysis on the probability to be a migrant: Albania only with extensive list of variables

Table 3.1 Theoretical motivations to remit

Table 3.2 Average amount remitted during the past year by remitter characteristics in PPP US\$

Table 3.3 Variables and expected effects for combined model

Table 3.4 Results of Tobit regression for combined model

Table 3.5 Variables and expected effects for Albania model

Table 3.6 Results of Tobit regression for Albania model

Table 3.7 Variables and expected effects for Moldova model

Table 3.8 Results of Tobit regression for Moldova model

Table 4.1 Descriptive statistics for variables in multinomial logit regression Table 4.2 MTO services offered by commercial banks, Moldova, January 2008

Table 4.3 Regression results (multinomial logit): Transfer channel choice

Table 5.1 Immigrant Integration Index

Table 5.2 Immigrant group and remittance channel usage in percentages

Table 5.3: Immigrant group and bank usage in percentage

Table 5.4 Probit for sending money formally

Table 5.5 Probit for the decision to transfer through a Bank 
Table 6.1 Descriptive statistics among sampled households (from CBSAXA survey)

Table 6.2 Probit and IV probit results for predictors of any health expenditure Table 6.3 OLS and IV Two-stage least squares estimation results for predictors of amount of health expenditure, among households reporting any health expenditure 


\section{List of figures}

Figure 2.1 The Welfare Pentagon

Figure 2.2 The livelihood portfolio decision

Figure 2.3 The migration decision making process

Figure 3.1 Albania emigration and remittances

Figure 3.2 Moldova emigration and remittances

Figure 3.3 Amount of remittances by expenditure quartiles

Figure 3.4 Number of years remitter has been abroad

Figure 4.1 Labour migrants 1999-2008

Figure 4.2 Migrants Remittances 2000-2008

Figure 4.3 Average balance on bank accounts, by type, 1999-2008

Figure 5.1 Total people of foreign nationality in the Netherlands

Figure 5.2 Remittances sent from the Netherlands

Figure 5.3 Population of foreign origin 2005

Figure A5.1 Working share of labor force by ethnic group 2003

Figure A5.2 Education level attained by 15-64 yr old non-school-goers 2002

Figure 6.1 Labour migrants 1999-2008 (thousands, 199-2005 adjusted)

Figure 6.2 Migrant remittances from National Bank estimates, electronic transfers and money transfer operators, 2000-2008 (US\$ million; 2008 estimated) 


\section{Chapter 1: Introduction}

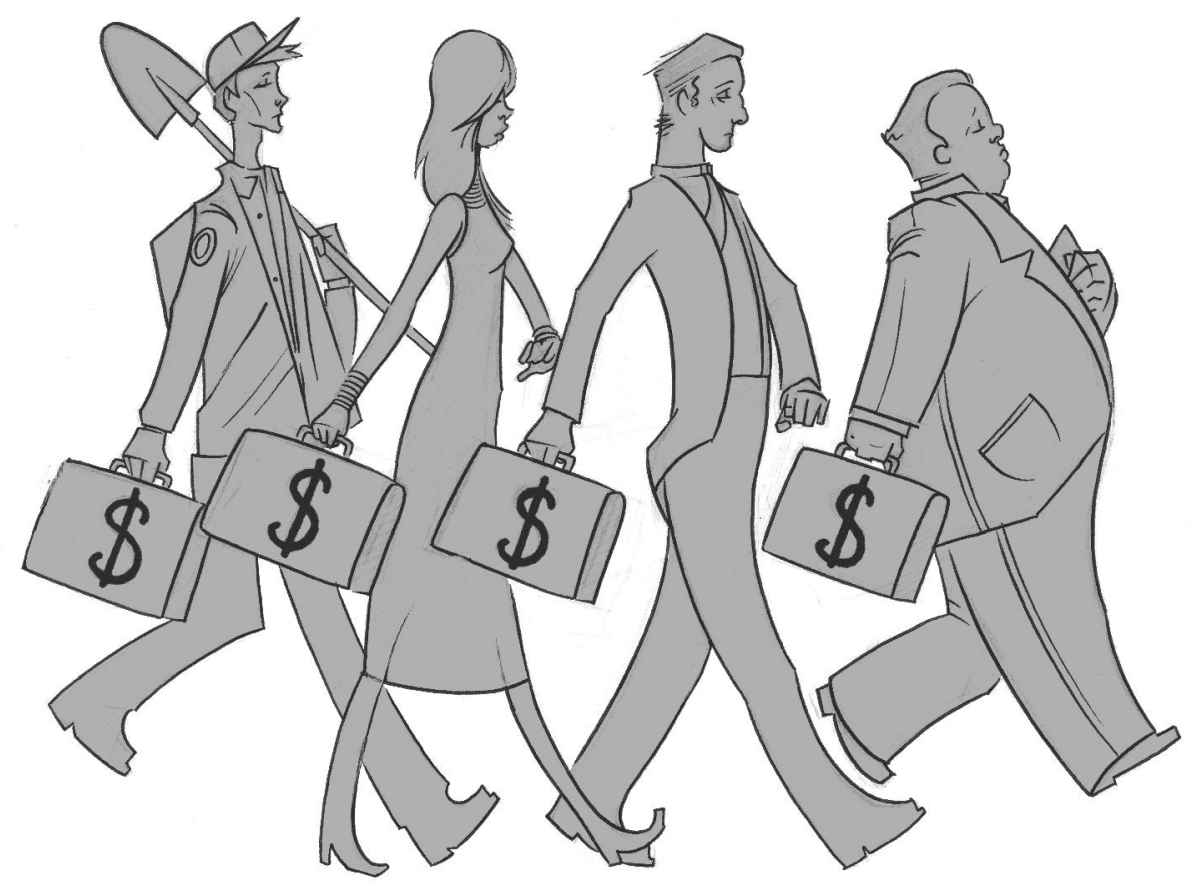




\subsection{Introduction}

In recent years, migration has increased rapidly and become a more prominent feature of the world economy and the public policy debate. According to the United Nations, there are estimated to be more than 200 million international migrants in $2010,{ }^{1}$ a number which constitutes three percent of the world's population. To put this number in perspective, this figure would amount to the fifth most populous country in the world. Remittances, the money that the migrants send back to their home countries, have reached extraordinary levels in the last years: with the increase in migration, there has also been an increase in the amount of money sent home by migrants. It was estimated in 2008 that $\$ 328$ billion in formal ${ }^{2}$ remittances were sent by migrants abroad back to their countries of origin (Ratha, Mohapatra, and Silwal, 2009). It is approximated that at least another $50 \%$ of remittances are sent informally3. The amount of remittances flowing into countries has surpassed the money given for official development aid (ODA) and, in many countries, foreign direct investment (FDI). According to the Migration and Remittances Factbook (Ratha et al. 2008), in more than 40 countries, migrant remittances account for $10 \%$ or more of GDP, and in some countries remittances account for $30 \%$ or more. The impact of these flows have macro implications for both the migrant-sending and migrant-receiving country as well as implications on the micro (individual or household) and meso (community) level. Migration and remittance-sending process and trends have enormous implications for national economies, individuals, households, communities, and the public policy that is crafted to govern them. It is thus imperative to understand these processes as they evolve to contribute to the creation of better informed and responsive policy initiatives.

This dissertation primarily focuses on processes and consequences of economic migration and more specifically on the processes and consequences of remittance sending/receiving. By focussing on economic migration, we largely ignore refugee flows and forced migration. Although there are approximately 13.5 million refugees world wide, this number amounts to only a small portion $(7.1 \%)$ of the total migrant population (Ratha et al., 2008). Most people still migrate for economic

\footnotetext{
${ }^{1}$ Source: United Nations, Department of Economic and Social Affairs, Population Division (2009). Trends in International Migrant Stock: The 2008 Revision (United Nations database, POP/DB/MIG/Stock/Rev.2008).

${ }^{2}$ Formal remittances are those remittances which are registered and accounted for by governing bodies such as Central Banks. Formal remittances are sent through formal channels such as banks or money transfer operators (MTOs) that are usually licensed or registered.

${ }^{3}$ Informal remittances are those that are sent through channels that are not licensed or formally regulated. These channels can include the migrant simply carrying the money themselves or sending it with someone else as well as transfers sent through underground banking operations or informal money transfer agents, to name a few.
} 
reasons, which can manifest themselves through family reunification or marriage migration schemes as well as traditional migration for purely economic reasons. Although this publication will specifically address issues of remittances, it pays substantial attention to migration in general, especially in the first and the second chapter. Chapter Two focuses on the determinants of migration that prompt economic migrants to leave their countries of origin. This chapter addresses the questions of why people migrate and what allows them to do so. After gaining more understanding of why people move and what makes them able to do so, we turn to why people send money once they have moved. Chapters Three, Four, and Five focus on remittances that could be sent by any type of migrant. Chapter Three assesses determinants of remittances, how remittances are currently empirically measured, and whether current measurement methods are appropriate. It uses a case study of Moldovan migrants (most of whom are economic migrants) to illustrate these principles. Chapter Four further elaborates on the discussion of remittances by testing how migrants send remittances once they have decided to do so. The main topic this chapter covers the determinants of remittance channel choice, and it uses the case of Moldovan economic migrants to explore channel availability and choice. Chapter Five looks at remittances sent from the Netherlands by all types of migrants. This chapter continues on the remittance channel choice topic but asks the question of whether immigrant integration has an effect on the remittance channel decision. Chapter Six returns to the case of Moldovan migrants to assess the manifest effects of migration on particular indicators. From the determinants of migration to the determinants of remittances and then remittance channel choice, the last empirical chapter looks at effects of migration on health care spending in the sending country. This chapter assesses if there is a difference between migrant and non-migrant households with regard to household health care expenditure.

\subsection{Effects of migration and remittances}

The literature on the effects of migration and remittances is extensive and growing at steady pace as the developed world is wondering about the function, impact and future of immigration in their countries, while the developing and emerging economies want to estimate the positive and negative impact of migration out of their countries. Theories are refined and data bases collected and explored. Despite the fact that we will argue in chapter two that still quite some efforts have to be made in order to integrate insights from various disciplines and to collect and analyse data that allows us to test sophisticated hypotheses, past research has generated a rich set of insights and conclusions. We discuss these conclusions in the rest of this chapter, emphasizing the positive and negative effects of migration and remittances for the migrant's sending and host country. 


\subsubsection{Positive effects}

According to previous studies, migration produces a number of positive as well as negative effects for both the migrants' home and host countries. We will first assess the positive effects which migration creates for the migrant-sending country.

The members of the diaspora of a particular country can sent remittances to their home (sending) country and these remittances can be seen as increased financing available to reducing poverty and sustaining and improving livelihoods of households (Acosta et al., 2007; Adams, 1991; Adams, 2004; Adams, 2006a; Adams et al,. 2003; Adams et al., 2005; Itzigsohn, 1995; Taylor et al., 2005). Remittances can reduce poverty, help smooth household consumption (especially during adverse shocks like crop failure or job loss), ease working capital constraints on farms and small-scale entrepreneurs, and lead to an increase in household expenditure (World Bank, 2006). Acosta et al. (2007) find in a survey across 11 Latin American countries that remittances lower poverty in most recipient countries despite the fact that their estimated impact is not large. They also find significant country heterogeneity with regard to the impact of remittances on poverty reduction. In Adams (1991), the comparison is made beween expenditure behaviour of migrant and non-migrant households in Egypt. He finds that only a relatively small amount of money goes into consumption (12\%) and a relatively large amount is used for housing (54\%). Migrants also have a higher propensity to invest than nonmigrants. In another study by Adams (2006b), he uses a nationally-representative household survey to analyze the impact of internal and international remittances on poverty in Ghana. With one exception, he finds that both types of remittances reduce the level, depth, and severity of poverty, and international remittances reduce the severity of poverty more significantly. Similarly, Adams (2006a) finds that both internal and international remittances reduce the level, depth, and severity of poverty in Guatemala. In an earlier study of low-income household subsistence strategies in the Caribbean basin, Itzigsohn (1995) shows that migrant remittances constituted an important source of income.

Remittances can also increase investment in education by loosening capital constraints (Cox-Edwards et al., 2003; Acosta et al., 2007), can increase health outcomes, (Hildebrandt et al., 2005; Mansuri, 2007) and can help reduce inequality. Acosta et al. (2007) in the same study previously mentioned also find that remittances tend to have a positive impact on education and health, although this is only for particular parts of the population. In addition to being more effective in reducing poverty as migration increases, Taylor et al. (2005), using data from Mexico, find that remittances for international migrants become more equalizing 
(creating less inequality). The problem is that, although migration loosens capital constraints, it also tightens labor constraints in household activity (including farm activity, child and elderly care, etc.) (e.g. Cox-Edwards and Ureta, 2003). De Brauw and Giles (2006), find that for those approaching school-leaving age, the opportunity cost of schooling increases as migration becomes more common because migration becomes available as an outside option. This has been found to be a negative incentive (especially for males) for continued education in some parts of Mexico.

Another important issue for welfare gains is that of "brain gain". In countries where migration is uncertain, some brain drain could increase average productivity (Mountford, 1997). Stark and Wang (2002) require a social return to education to show that migration may induce additional human capital investment by raising the expected returns to additional schooling when there are social returns to schooling. Schiff (2005), however, shows the gains are much smaller in a different setting. Brain gain can occur from skills acquired while abroad if migrants return. Dustmann and Kirchkamp (2002) show brain gain occurring in Turkey due to the return of migrants from Germany while Gang, Co, and Yun (2000) show positive returns to migration among female (but not male) migrants returning to Hungary.

Migration can also positively affect sending-country economies via remittances. The money that is sent through formal channels can be used by the home country's central bank to securitize against future loans, allowing them to borrow money in the international arena. Remittances are a source of foreign exchange and thus affect the balance of payments (BOP). Foreign exchange can alleviate the BOP burdens and pay for imports (Bugamelli et al., 2005; Ratha, 2003; Ratha, 2006). Ratha (2006) explains that remittances can improve a receiving countries' credit worthiness, and securitization can help countries raise external financing. At a macro level, remittances are considered to be a stable source of external financing and are often countercyclical. For instance, Clarke and Wallsten (2004) observed an increase in remittance flows after natural disasters; Yang (2005) showed that remittances to the Philippines increased following the 1997 financial crisis.

Furthermore, migration can lower unemployment rates when so many workers have left the country, which also increases wages. All of this has the potential to help increase economic growth in the country. The remittances that are used for consumption can help meet everyday needs and stimulate the economy. Remittances that are used for investment have an even greater multiplier effect, which creates more economic growth. There is a large debate over remittances used for consumption or investment in the literature, but it is clear that both consumption and investment of remittances have a multiplier effect, although this 
effect is estimated to be of different magnitudes (Adams, 1998). The highly-skilled circulation is another important benefit of migration for both the home and host country (Batista et al., 2007). Migration and remittances can increase development through the many positive effects stated above (Agunias, 2006; De Haas, 2005).

For the migrant receiving country (destination or host country), the migrant labor can increase productivity, reduce scarcity of labor, and help to increase labor-force dependency ratios that can help alleviate some of the problems associated with aging populations in host countries. The expected decline in the labor force in high-income countries due to aging populations and low birth rates will increase dependency ratios, and migration could play a key role in easing this burden (World Bank., 2006). Since there is an increased return to capital, wages of native populations are likely to increase. All of these factors can spur economic growth (World Bank, 2006). A much-overlooked benefit to host countries is the increased cultural diversity that comes along with migration. There are mixed results on the impact of migration on natives' wages (in high-income countries) but natives do enjoy a rise in income as returns to capital increase, which offsets the possible decline in wages (World Bank, 2006).

Overall, migration can generate a large increase in global welfare even though the relative number of migrants compared to the native labor forces is small (World Bank, 2006). The global income gains alone could be $\$ 356$ billion (a 0.6 percent increase in global income) with the percentage gain to low income countries even greater at 1.8 percent. If migration increases significantly, these gains could be even greater. Although migration can generate significant economic gains for those involved (migrants, origin countries and destination countries), migration can also have important political and social consequences (World Bank, 2006).

\subsubsection{Negative effects}

Although there are numerous positive effects for both migrant-sending and receiving countries, there are also possibilities for negative effects of migration and remittances. For the home country, it is possible that the most productive people in the society (the brains) are the ones that leave, causing a "brain drain" that hinders development (Özden et al., 2006; Schiff et al., 2008). The sending of remittances may cause moral hazard (Chami et al., 2003) and Dutch disease, and large remittance flows can lead to exchange rate appreciation and lower export competitiveness, (Amuado-Dorantes et al., 2004; Bourdet et al., 2006). Moral hazard can happen when the people left behind have less incentive to work and leave the labour market due to the money sent home. A rise in remittances reduced the labour force participation in Managua, Nicaragua, but also increased selfemployment (Funkhouser, 1992). In several Caribbean countries, Itzigsohn (1995) 
found that remittances reduced the participation rates of the remaining household heads. Yang (2004) puts a more positive spin on the reduction of labour force participation. He finds that remittances reduce child labour and increase adult labor. As Yang (2004) points out, not all labour reduction in bad. In some cases, remittances allow for more education instead of work, which will have increased positive effects in the future. Dutch disease happens when new large flows of money enter the country, raising the value of the local currency and making domestic products more expensive to importers, which can lower export competitiveness. While remittances can decrease inequality, depending on who is sending and receiving remittances, they can also increase inequality (Barham et al., 1998).

One must also remember the social and emotional costs of a member of a family being abroad. For instance, parents sometimes leave children to be cared for by grandparents or in some areas, all the men have left, which leaves an unfamiliar social set-up. There could be lasting negative social effects of so many children being left behind (sometimes to care for themselves) in countries like Moldova.

For the host country, it is possible that the immigrant population may push wages down since there is an added supply of labor (Borjas, 1999). Immigration can also be difficult for social cohesion since there is an inflow of people from different cultures. These different cultures can cause problems for integration. More immigrants can also be a strain on the receiving-country infrastructure, some institutions, and public finance.

"Brain drain" or "brain waste" are other important negative aspects of migration. "Brain drain" occurs when highly skilled workers leave a country and usually do not return, taking all of their knowledge with them. This is particularly problematic in settings where their skills are scarce and/or where public funds have been used to educate them. Adams (2003) shows how pervasive this issue is and how it has led to shortages of specific workers in specific countries. A clear example of this problem is in Guyana, where 89 percent of skilled workers have migrated (Docquier and Marfouk, 2005). These shortages are particularly pervasive in the public sector and in the medical field. Small island nations are among those most affected by brain drain. Brain drain is particularly problematic in countries where people attain higher education just as a way to leave the country. "Brain waste", on the other hand, can occur in two different ways. If a small country over-invests in a specific type of human capital (for example, doctors) and also does not allow emigration, unemployment rates will be relatively high among workers who have that type of human capital. If people are not allowed to leave or do not leave when given the choice, then brain waste will occur. Brain waste can also occur (and often does) when highly-skilled migrants cannot find employment 
in line with their skills after migrating. Mattoo, Neagu, and Ozden (2008) show that highly-skilled immigrants to the United States from Eastern Europe and Latin America tend to be unable to find employment in the area in which they are trained. Brain waste occurs, then, when migrants could use their human capital more effectively if they were employed in the sector for which they are trained.

\subsection{Policy}

The myriad of possible effects migration and remittances can reek on both home and host country have transformed them into an important polity area. Migration and remittances overlap several policy areas in both home and host country, but two of the main areas in which migration and remittances are addressed are in immigration and development policy. According to Carling (2008), for Europe the remittances alone are highly relevant in four overlapping policy areas: (1) there are countries in Europe that are heavily dependent on remittances and need policies to increase the developmental impact of remittances (like Moldova and Albania highlighted in this dissertation); (2) remittances are relevant for overall migration management (which includes the global competition for the highly skilled, the prevention of unwanted migration, and development in the country of origin); (3) remittances are part of many regulatory and law enforcement issues; (4) remittances play a role in immigrant integration.

There are continuously large debates over where or not to open countries to more immigration. Policies to further liberalize (open) migration flows into developed countries are often faced with hard opposition. Proponents of liberalization tend to argue that increased migration offers opportunities to further the economic development of both sending and receiving countries, while opponents emphasize economic, political, and social drawbacks (Carling, 2008).

There is a prohibitive lack of quality information about how various policies affect migration, remittances, and the households who participate in migration. The first step in bridging this gap is simply in better understanding the phenomena that inform the policy development process. The lack of information is most marked in two main dimensions: (1) in terms of information about the size and character of migration flows and migrants themselves, (2) and in terms of the relationship between migration, its potential effects on source communities, and policy (de Brauw and Carletto, 2008). This dissertation adds a substantial body of new information to the knowledge of these processes.

\subsection{Outline of the dissertation}

This dissertation covers a pivotal range of issues that are necessary to understand and appropriately frame migration and remittances within the context of 
unprecedented magnitude and impact. Using case studies to test theoretical frameworks created to explain the mechanisms and processes involved in both migration and remittance transmission, this dissertation rigorously analyses the explanatory factors used in theoretical frameworks to demonstrate their usefulness and utility in predicting migration and remittance trends.

Chapter Two begins with a discussion of the reasons that prompt migration. This chapter takes an innovative approach to migration causation theory by applying the Welfare Pentagon theoretical framework, which has been used before in social risk management, for explaining migration patterns and trends. The Welfare Pentagon, when applied to the context of migration, maps the reasons that an individual is inclined to move by assessing their ability to access the five different parts of the Welfare Pentagon. The Pentagon indicates the possible access a household has to the market, the state, the family, social networks, and membership institutions. In this case of migration causation, access to these five realms are then used to explain how individuals are enabled to migrate if they so desire. After mapping this theoretical framework, the chapter goes on to test the framework with the cases of Albania and Moldova. Both countries have experienced remarkable levels of out migration, and the application of the Welfare Pentagon as an explanatory framework yields considerably richer predictive value. The chapter finds evidence that the framework is a valuable and novel approach that can be analytically useful for the migration studies field in total: the chapter will demonstrate that not only money matters when it comes to the ability to migrate, but access to the whole range of areas covered by the Welfare Pentagon is highly relevant to the decision and ability to migrate.

Remittances are often sent to the families left behind in the home country following the migration of a household member, but determinants of remittance-sending patterns and behaviour are still crudely understood. Chapter Three lends new clarity to this topic by specifically asking the question: what determines the sending of remittances? This question incites a review of the existing theories of why migrants send money, and the assessment ranges from theories positing pure altruism to those proposing pure self-interest and carefully documents the range of theories in between. The chapter then takes a critical view of the testing of these theories in the current literature and uses data from Albania and Moldova to illustrate the difficulty with empirically testing these motives. Many of the variables used to test remittance-sending motives generate conflicting results, and it is extremely difficult to pull results apart to differentiate between motives. This chapter gives a cautionary note about drawing too many conclusions from current empirical research on the topic, and it reiterates the need for better empirical understanding of differentiated motives that inform migrants' choices to remit. 
Remittances are sent to individuals all around the world in societies with varying degrees of infrastructural development, thus the manner in which remittances travel to their final destinations is highly variable. Given the large amount of money sent as remittances and dramatic impact on the lives of recipients and nonrecipients alike, it is important to understand ways that remittances can be made easier and less expensive to send to ensure that more of the money reaches the final destination. Recently, international organizations such as the World Bank and the International Monetary Fund have made it a priority to encourage the sending of remittances through formal channels. There are two main reasons for this. One reason is the strong concern after the terrorist attacks of September 11, 2001, that money travelling through informal channels is more susceptible to money laundering and terrorist financing, and there is thus a greater need to regulate and encourage transparency in money flows in general. The other reason is to increase the developmental impact of remittances due to large multiplier effects. When remittances are sent through the formal sector and, banks in particular, the money helps strengthen the financial sector in the home country. More money flowing through banks means that there is more money available for use in finance loans. The money that is sent through the formal sector can be counted and can be used by the country's central bank to securitize future flows to gain loans from international donors, which can also be used to spur further growth and development. If remittances are sent through formal financial institutions, those institutions can offer a range of other banking products that help to create more financial literacy and consequently help "bank the unbanked."

Chapter Four investigates this developmental approach to understand why Moldovan migrants send money through the different channels they do. The chapter looks at the explicitly-stated motives Moldovan migrants declare for sending money through specific channels such as cost, speed, convenience, security, accessibility, familiarity and trust in the service provider. It also includes explanatory variables such as the destination country, level of education of the remitter, the remitter's time abroad, etc. The regression analysis has identified several important reasons why approximately one half of the Moldovan migrants and their families in the sample do not use formal transfer channels. Migrants who primarily use informal services are more likely to be in high-income countries (mostly the EU), reside in the host country illegally, remain abroad for periods longer than one year, do not have a bank account, and list cost of the transfer (rather than speed, convenience, security, or familiarity) as the most important factor in choosing a money transfer service. Migrants who rely mostly on personal transfers are more likely to work in CIS countries, remain abroad for less than one year, send remittances irregularly, and care primarily about the cost of the transfer (rather than speed, convenience, or security). 
Some of these determinants suggest the presence of distortions that can potentially be reduced through appropriate policy measures. Other determinants reflect migration patterns such as seasonal or irregular migration that will probably cause some migrants to use personal transfers or informal services irrespective of the wider institutional and policy environment.

Chapter Five continues assessment of the remittance channel decision, but this time it approaches the issue from the remittance sending country perspective. The case of the Netherlands is used to explicitly tackle the question: Does immigrant integration make a difference in the remittance channel decision, and what other factors could be influencing this decision? The specific migrant groups analyzed are the Turks, Moroccans, Surinamese, Antilleans, Ghanaians, and Somalis. The chapter finds mixed evidence for the hypothesis that migrants who are more integrated are more likely to send money through formal institutions (especially banks.) Instead, the chapter finds that policies and institutions matter in connecting migrant populations to different remittance channels. Those countries that have taken a specific interest in migrants sending remittances back to the home country through banks (like Turkey) and have set up the necessary infrastructure have a much higher degree of remittances sent through banks than countries that have failed to set up a similar infrastructural framework.

Once remittances reach their destination, they can have varying effects on households in the home country. Chapter Six concentrates on the effects of remittances on those left behind. This chapter explores the difference between migrant and non-migrant households as well as remittance-receiving and nonremittance receiving household with regard to their health care expenditure in a given year. Moldova is used as the case for this empirical work. Interestingly, the chapter shows that non-migrant households spend more money on health care than migrant households.

This dissertation makes contributions to the vast research area of migration and remittances. Each chapter uniquely augments the existing literature and critically assesses the commonly-accepted approaches to migration and remittance theory. Chapter Two's application of a novel and inventive theoretical framework to migration causation theory expands on the existing literature and provides another lens through which the analysis of the reasons a person migrates can be approached. Chapter Three takes a critical view of the current literature on the empirical testing of the motives to remit and identifies the current weaknesses in empirical testing. In doing so, the chapter explores the difficulties inherent to empirical testing of motives and provides a more critical discussion of the dubious reliability of derived results. Chapters Four and Five add considerable bulk to the sparse literature on remittance channel choice. While the study of remittances has 
dramatically increased in the past few years, systematic investigation into remittance channel choice and the impact those channels can have on the development potential of remittances has seldom taken place. This dissertation has been particularly instrumental in filling that gap. Finally, Chapter Six's exploration of the effect of migration and remittances on health care expenditure investigates a link between migration and development that has been largely ignored by previous literature. The impact of migration on health care expenditure as an indicator of development can be extremely telling of the development potential migration has within particular country contexts, and this chapter adds an additional layer of richness to the assessment of the migration-development relationship.

The chapters in this dissertation are written as separate publications and most of them are published or about to be published in journals and edited volumes (see first footnotes within each chapter). This means that smaller parts of the chapters show some overlap which is necessary to turn each of them in a stand-alone article. We tried to reduce overlapping paragraphs to a minimum, but the remaining overlaps are unavoidable. 


\subsection{References}

Acosta, P., P. Fajnzylber, et al. (2007). The Impact of Remittances of Poverty and Human Capital: Evidence from Latin America Household Surveys. International Migration, Economic Development and Policy. Ç. Özden and M. Schiff. Washington, D.C., World Bank.

Adams, R. H. (1991). The Effects of International Remittances on Poverty, Inequality and Development in Rural Egypt. Washington, D.C., International Food Policy Research Institute.

Adams, R. H. (1998). "Remittances, investment and rural asset accumulation in Pakistan." Economic Development and Cultural Change 47(1): 155-173.

Adam, R. H. (2003) "International Migration, Remittances and the Brain Drain: A Study of 24 Labor-Exporting Countries", World Bank Policy Research Working Paper 3069.

Adams, R. H. (2004). "Remittances and poverty in Guatemala." World Bank Policy Research Working Paper 3418.

Adams, R. H. (2006a). Remittances, Poverty, and Investment in Guatemala. International Migration, Remittances and the Brain Drain. Ç. Özden and M. Schiff. Washington, D.C., World Bank.

Adams, R. H. (2006b) Remittances and Poverty in Ghana. World Bank Policy Research Working Paper No. 3838.

Adams, R. H. and J. Page (2003). "International migration, remittances and poverty in developing countries." World Bank Policy Research Working Paper 3179.

Adams, R. H. and J. Page (2005). "Do international migration and remittances reduce poverty in developing countries?" World Development 33(10): 1645-1669.

Agunias, D. R. (2006). Remittances and Development: Trends, Impacts and Policy Options: A review of the Literature. Washington, D.C., Migration Policy Institute.

Amuado-Dorantes, C. and S. Pozo (2004). "Workers' remittances and the real exchange rate: A paradox of gifts." World Development 32(8): 1407-1417.

Barham, B. and S. Boucher (1998). "Migration, remittances, and inequality: estimating the net effects of migration on income distribution." Journal of Development Economics 55(2): 307-331.

Batista, C., A. Lacuesta, et al. (2007). "Brain Drain or Brain Gain? Micro Evidence from an African Success Story." IZA Discussion Paper 3035.

Borjas, G. (1999). Heaven's Door: Immigration Policy and the American Economy. Princeton, Princeton University Press, 
Bourdet, Y. and H. Falck (2006). "Emigrants' remittances and Dutch Disease in Cape Verde." International Economic Journal 20(3): 267-284.

Bugamelli, M. and F. Paterno (2005). "Do Workers' Remittances Reduce the Probability of Current Account Reversals?" Wold Bank Policy Research Working Paper 3766.

Carling, J. (2008) “The Determinants of Migrant Remittances", Oxford Review of Economic Policy.

Chami, R., C. Fullenkamp, et al. (2003). "Are Immigrant Remittance Flows a Source of Capital for Development?" IMF Working Paper WP/03/189.

Clarke, G. and S. Wallsten (2004) "Do Remittances Protect Households in Developing Countries Against Shocks? Evidence from Natural Disasters in Jamaica", World Bank.

Cox-Edwards, A. and M. Ureta (2003). "International migration, remittances, and schooling: evidence from El Salvador." Journal of Development Economics 72(2): 429-461.

De Brauw, A. and G. Carletto (2008) "Improving the measurement and policy relevance of migration information in multi-topic household surveys", World Bank.

De Haas, H. (2005). "International migration, remittances and development: myths and facts" Third World Quarterly 26(8): 1269-1284.

Doquier, F. and A. Marfouk (2005) "International Migration by Educational Attainment, 1990-2000, " in M. Schiff and C. Ozden, International Migration, Remittances and Brain Drain. Washington, D,C., World Bank

Dustmann, C. And O. Kirchkamp (2002) “The Optimal Migration Duration and Economics Activities after Return Migration." Journal of Development Economics, 67: 351-372.

Gang, I., Co, C. and M. Yun (2000) "Returns to Returning," Journal of Population Economics 13:57-80.

Hildebrandt, N. and D. J. McKenzie (2005). "The Effects of Migration on Child Health in Mexico." World Bank Policy Research Working Paper 3573.

Itzigsohn, J. (1995). "Migrant Remittances, Labor Markets and Household Strategies: A Comparative Analysis of Low-Income Household Strategies in the Caribbean Basin." Social Forces 74: 633-655.

Mansuri, G. (2007). Does Work Migration Spur Investment in Origin Communities? Entrepreneurship, Schooling, and Child Health in Rural Pakistan. International Migration, Economic Development and Policy. Ç. Özden and M. Schiff. Washington, D.C., World Bank.

Mattoo, A., Neagu, I. And C. Ozden (2008) “Brain Waste? Educated Immigrants in the US Labor Market," Journal of Development Economics.

Mountford, A. (1997) "Can Brain Drain be Good for Growth in the Source Economy?" Journal of Development Economics 53 (2): 287-303. 
Özden, Ç. and M. Schiff (2006). International Migration, Remittances and the Brain Drain. Washington, D.C., World Bank.

Ratha, D. (2003). Workers' Remittances: An Important and Stable Source of External Development Finance. Global Development Finance. Washington, D.C., World Bank.

Ratha, D. (2006). Trends, Determinants and Macroeconomic Effects of Remittances. Global Economics Prospects 2006: Economic Implications of Remittances and Migration. Washington, D.C., World Bank.

Ratha, D., Mohapatra, S., \& Silwal, A. (2009). “Outlook for Remittance flows 20092011". Migration and Development Brief 11, World Bank.

Ratha, D. and Z. Xu (2008). Migration and Remittances Factbook 2008. Washington, D.C., World Bank.

Schiff, M. (2005) "Brain Gain: Claims about Its Size and Impact on Welfare and Growth are Greatly Exaggerated," IZA Discussion Paper No. 1599.

Schiff, M. and Y. Wang (2008). "Brain Drain and Productivity Growth: Are Small States Different?" IZA Discussion Paper 3378.

Stark, O. And Y. Wang (2002) "Inducing Human Capital Formation: Migration as a Substitute for Subsidies," Journal of Public Economics 86:29-46.

Taylor, J. E., J. Mora, et al. (2005). Remittances, Inequality and Poverty: Evidence from Rural Mexico. American Agricultural Economics Association Annual Meeting. Providence, Rhode Island.

World Bank (2006). Global Economics Prospects: Economic Implications of Remittances and Migration 2006. Washington, D.C.

Yang, D. (2005) "Coping with Disaster: The Impact of Hurricanes on International Financial Flows 19970-2001", Research Program on International Migration and Development, World Bank. 


\section{Chapter 2: A livelihood portfolio theory of migration}

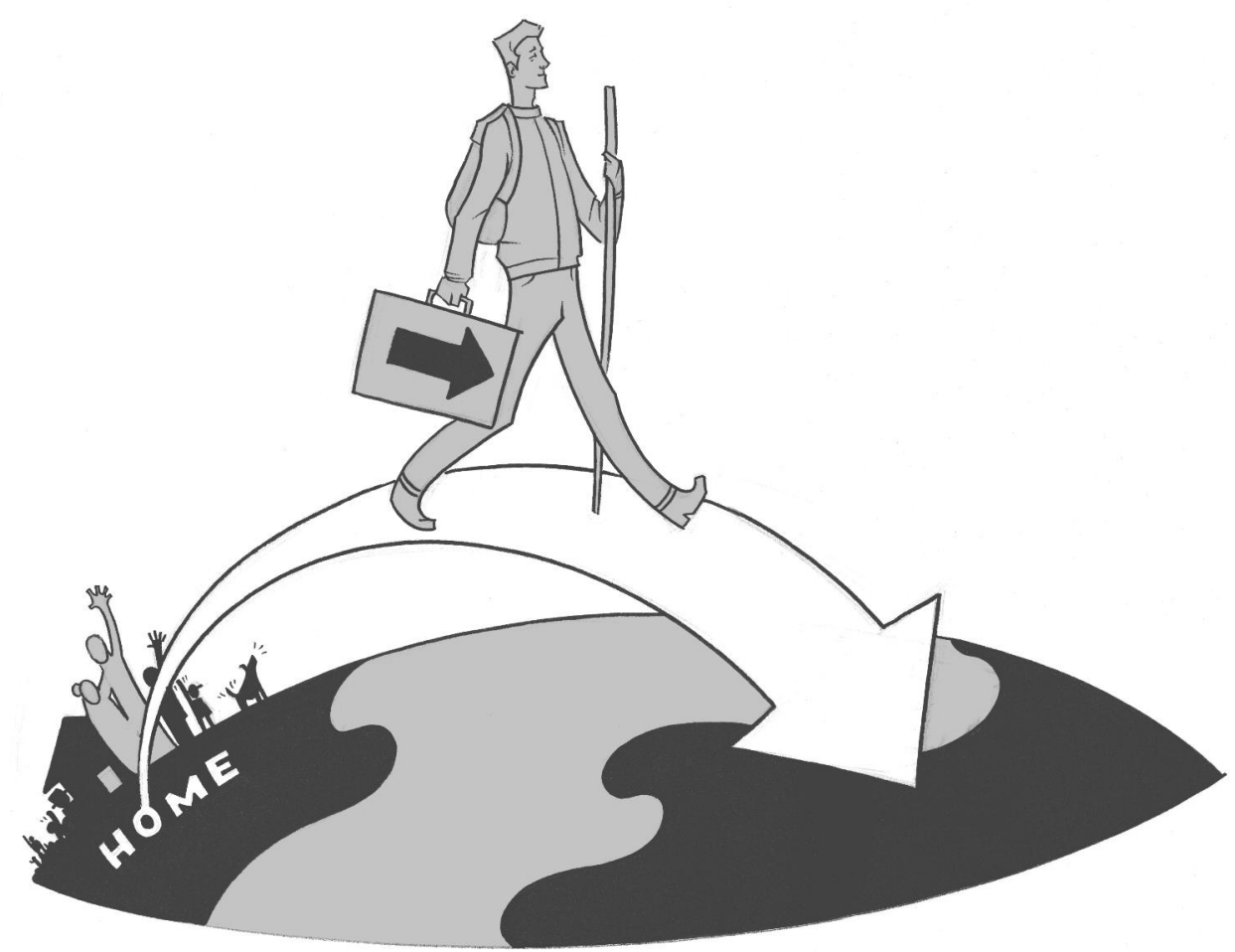




\subsection{Introduction ${ }^{45}$}

This paper presents a theoretical framework that intends to integrate a noteworthy part of the empirical findings in earlier studies explaining why people migrate and how decisions on destination countries are made. The paper ends with exploring existing data sets for Albania and Moldova to study whether standard data bases could be used to test the theory. The theoretical framework wants to contribute to our understanding of what drives migrants to move out of their country of origin, what makes them choose for a particular destination country and which incentive(s) finally will play a crucial role in deciding whether they will settle in the destination country or whether they would return to the sending country (or eventually move on to a third country).

The theoretical framework, on which the analysis is based links the incentives and the impediments to migration to institutional constraints and the lack of (household- and individual) assets necessary to use migration as an income generating or consumption smoothing strategy for households and individuals.

\subsection{A livelihood portfolio theory}

\subsubsection{Livelihood portfolio decisions within the welfare pentagon}

We make use of the basic economic assumption that individuals and households ${ }^{6}$ maximize income under constraints. Furthermore we assume that all households face the risk of becoming poor at a certain point in the future. In other words, households are assumed to face the risk that they are not (no longer) able to fulfill the needs of their members, today as well as tomorrow. To prevent this risk from

\footnotetext{
${ }^{4}$ This chapter is based on the forthcoming article Strings Attached: The Impediments to Migration in the Journal of South-East European and Black Sea Studies (December issue) co-authored with Jessica Hagen-Zanker and Chris de Neubourg.

${ }^{5}$ Thanks to the participants at the Advanced Academic Update on Economic Migration, Maastricht, $18^{\text {th }}-19^{\text {th }}$ March 2008, participants at the Conference Migration and Development in Albania and the Western Balkans: Remittances, Return and Diaspora, Dũrres, 26-27 September 2008, George Borjas and an anonymous referee for helpful comments on an earlier draft of this paper.

${ }^{6}$ We juxtapose individuals and households in the explanation of the theory; in the end individuals can be regarded as single person households. When individual behavior is part of a household strategy, the theory becomes more complicated as the relationship between the household members have to be taken into account. The theoretical framework does not ignore that this might be the case and is even an important element when migration is considered, but we do not want to complicate the theoretical explanation at this stage.
} 
materializing, households smooth their consumption over time, setting aside part of their resources to finance future consumption. Additionally, when it becomes clear that income does (will) not suffice, households can seek alternative funding for the expenditures. When these measures are effective, households are able to maintain a particular welfare level, even when income falls short. Being able to generate income (wealth - "income" in this context is not limited to monetary resources) reflects the most important dimension of well-being since it reflects households' capacity to satisfy the needs of their members "today". Being able to smooth consumption reflects another important dimension of well being as it reflects people's capacity to satisfy their (basic) needs "tomorrow", despite the existence of risks and the occurrence of shocks'. In this section we argue that migration is an income generating as well as consumption smoothing strategy.

The welfare pentagon represents the five core institutions that households use to satisfy current and future needs in a given society: family, markets, social networks, membership institutions and public authorities (see Figure 2.1). ${ }^{8}$ Even though historical and geographical appearances differ, these institutions are found in all societies across time and locations. The relevance of each institution and the exchanges between households and these institutions though may differ by society and over time. It is assumed that households make decisions on their income generation and consumption smoothing activities by choosing a specific "production point" in the 5-dimensional space defined by the welfare pentagon.

\footnotetext{
${ }^{7}$ Studies analyzing the relationship between income and consumption show that, over time, household consumption is considerably smoother than income; a reduction (increase) in household income is not accompanied by a similarly large decline (increase) in consumption. Although there is considerable evidence that consumption smoothing takes place in both developed and developing countries, the underlying smoothing strategies actually used by households in different societies are highly context dependent, but basically follow a similar pattern. Mechanisms that work for one group, country or region do not work for others or are not accessible for other groups or to people living in a particular area. The economic literature typically analyzes consumption smoothing behaviour following two approaches; the first approach models household behaviour using a permanent income model or risk-sharing model and focuses on the overall smoothness of consumption vis-à-vis income flows (see Deaton, 1992 for an overview). The second approach models and tests particular consumption smoothing mechanisms for specific groups of households or regions (see for instance Dubois et al, 2006; Hoogeveen, 2001; Dercon, 1998, Ligon 1998, Udry 1994 and 1995; Rosenzweig, 1988; Rosenzweig and Wolpin, 1993; Kochar, 1999 and 2004, Alessi and Lusardi, 1997).

${ }^{8}$ The Welfare pentagon is a central and distinctive element in the 'Social Risk Management' approach as developed by de Neubourg (2002) and de Neubourg \& Weigand (2000). The Social Risk Management framework is formulated to analyze the role and scope of public interventions and foremost, but not exclusively, that of public social protection policies.
} 


\section{Figure 2.1: The Welfare Pentagon}

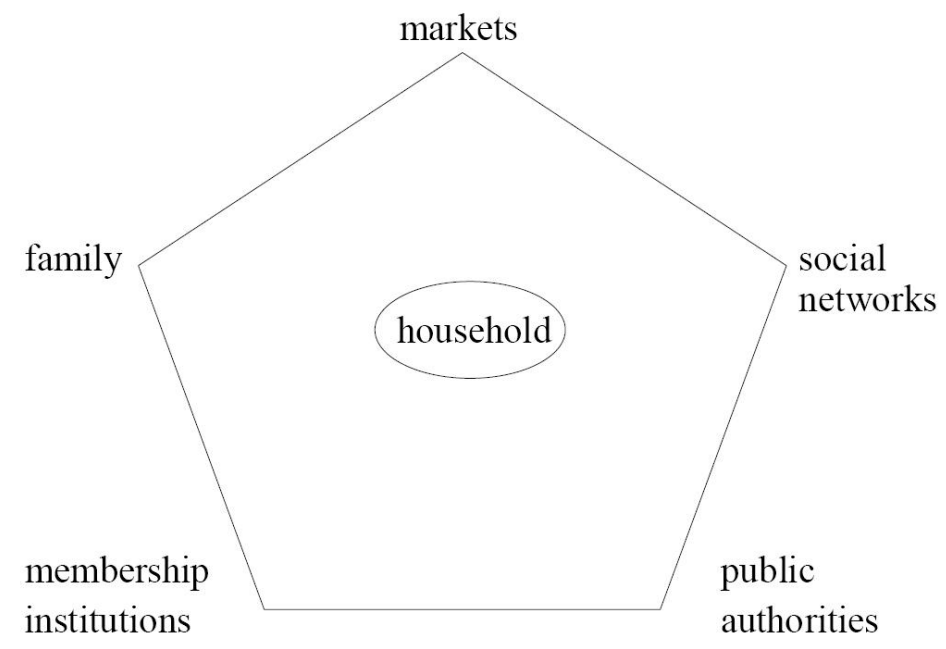

Source: de Neubourg (2002a)

Households use the institutions of the welfare pentagon in their livelihood strategy in order to generate income but also to smooth consumption; labor markets, product markets and capital markets allow households to trade and exchange in order to secure resources to satisfy the main needs at a certain moment. On the labor market households exchange effort for a (future) wage; on product markets households trade effort (producing a product or service) for a (future) profit (or in exchange of another good or service); on the capital market households trade current income for future income by investments, savings, insurances, borrowings and the like. Families, social networks and membership institutions help to address the livelihood risk by means of various (and different) mechanisms of solidarity (and exchange). Membership institutions are institutions of which individuals can become a "member" and from which they can resign (households or individuals enter and exit membership institutions). Examples of such institutions are unions, mutual insurance companies, religious organizations, co-operatives or neighborhood associations. As the fifth corner of the welfare pentagon, public authorities can assist households directly by means of public social protection (pension schemes, child benefits, unemployment insurance and other forms of social insurance) but also indirectly by enforcing contracts through a judicial system, introducing legislation aimed at correcting market failures (such as minimum reserve requirements for banks so that the savings of the households are guaranteed) and many other public actions. Although it is hard and unusual for households to go without the institutions of a welfare pentagon, households can 
also internalize income generating activities and consumption smoothing by autarchic home production, accumulating physical assets or holding cash savings.

In order to be able to follow a particular income generating and consumption smoothing strategy, households and individuals need access to the relevant institutions of the welfare pentagon. Obtaining a social security benefit requires access to the public authorities that control the social benefit; obtaining a (legal) wage depends on your access to the (legal) labor market; getting support from a family member implies having access to a family. In addition to access to a particular institution, specific income generating and consumption smoothing strategies typically also require some kind of asset or capital. Assets (capital) can be financial (cash, money on a bank account, savings, stocks, a credit line), physical (land, house, life stock, machines, jewelry), human (education, skills, time), social (family ties, acquaintances, trust) or collective (citizenship, contribution record). For instance, households can buy insurance against certain risks on financial markets using part of their financial assets to pay the insurance premium. Alternatively, households can be insured for certain risks by public authorities through paying taxes or social insurance contributions or simply by being a citizen or a legal resident. On the other hand, they can rely on social networks or family to generate income or compensate them after a shock occurs. Depending on the characteristics of these arrangements a social input is required. This input can take the form of a promise of reciprocity, a 'good' reputation or a family relation. The need for assets or capital that can be mobilized when income generation or consumption smoothing is sought, brings us to a very peculiar aspect of the welfare pentagon. The institutions of the welfare pentagon are present but their role in income generation or consumption smoothing can only be effectively "requested" when the individual or the household has a certain amount of capital available: human capital is required to enter the labor market, social capital is needed for making use of families and networks, political capital is needed to use public services, etc.

The amount of all forms of capital available to a person or a household, however, is neither fixed nor equal between individuals and households. The amount of capital available by individuals (households) is endowed or acquired by investments.

Individuals (households) differ in their initial (capital) endowments due to two main reasons. Firstly, they are not equal in their capacity to generate wealth. This originates, in turn, in two types of differences between them: on the one hand, they differ in intrinsic productivity, in age, in health and in other personal characteristics; on the other hand, they differ in immediate constraints such as household composition (e.g. single parents may have less opportunities to earn a living in the formal labor market). Secondly and at least as important, individuals are "born in an income distribution" (allowing for endowed wealth to be passed 
from past generations to present ones). These are important differences because their existence implies that households differ in the access to the institutions and in the endowed capital available related to each of the institutions of the welfare pentagon. This means that individuals (households) differ in their income generating opportunities and in their access to the consumption smoothing channels. In other words, individuals (households) differ in their initial capacity to follow a successful livelihood strategy (that means a strategy that allows them to fulfill their needs and to smooth consumption to a degree that needs can always be fulfilled).

The necessary capital to use one of the institutions (channels) of the welfare pentagon can, however, also be acquired. This is done by making investments and thus acquiring capital to be used to mobilize an institution of the welfare pentagon to generate income or to smooth consumption. This means that availability of all forms of capital is co-defined by various forms of investments that the individuals (household members) have made previously into the various types of capital; the returns on these investments are the collaterals that are implicitly or explicitly used when a welfare pentagon channel is activated to generate income or to smooth consumption. The institutions of the welfare pentagon are thus not only used to generate wealth or smooth consumption but the effectiveness of the welfare pentagon institutions in providing individuals (households) with income generating opportunities or consumption smoothing options, is a function of the investments made by the same individuals (households) into building all forms of capital with each of these institutions ${ }^{9}$ and by the initial endowment available to each individual (household).

Households also differ in their exposure to risks (meaning that some households are plagued by more "bad luck" than others) and in their preferences. Two sets of preferences are important in this respect: the preferences defining the "needs" of the household members and the preferences regarding the degree of risk aversion they find acceptable.

As a result of the differences spelled out above (initial endowment, risk exposure, needs definition and degree of risk aversion), households adopt different income generating and consumption smoothing strategies or in other words, households differ in their livelihood portfolio or in their particular place in the 5-dimensional space defined by the welfare pentagon. The theoretical framework allows

\footnotetext{
${ }^{9}$ A exception may be some charity institutions (a special form of membership institutions); to some charity institutions access is provided without building up capital prior to using the services of the charity organization. Remark that this does not hold for all charity organizations since some of them may require membership for some time or the promise of membership in the future (as is for example the case for some religiously inspired charity organizations).
} 
households to choose many "points of welfare production within the 5dimensional welfare space" all leading to the satisfaction of their needs. As already indicated, several institutions are active in providing assistance with income generating activities or consumption smoothing strategies. A part of the population may not have access to a particular income generating activity or consumption smoothing channel because it lacks the required capital/assets to establish an exchange relationship with the institutional counterpart related to that channel (institution). Figure 2.2 illustrates the livelihood portfolio decision and the different factors affecting it.

\section{Figure 2.2: The livelihood portfolio decision}

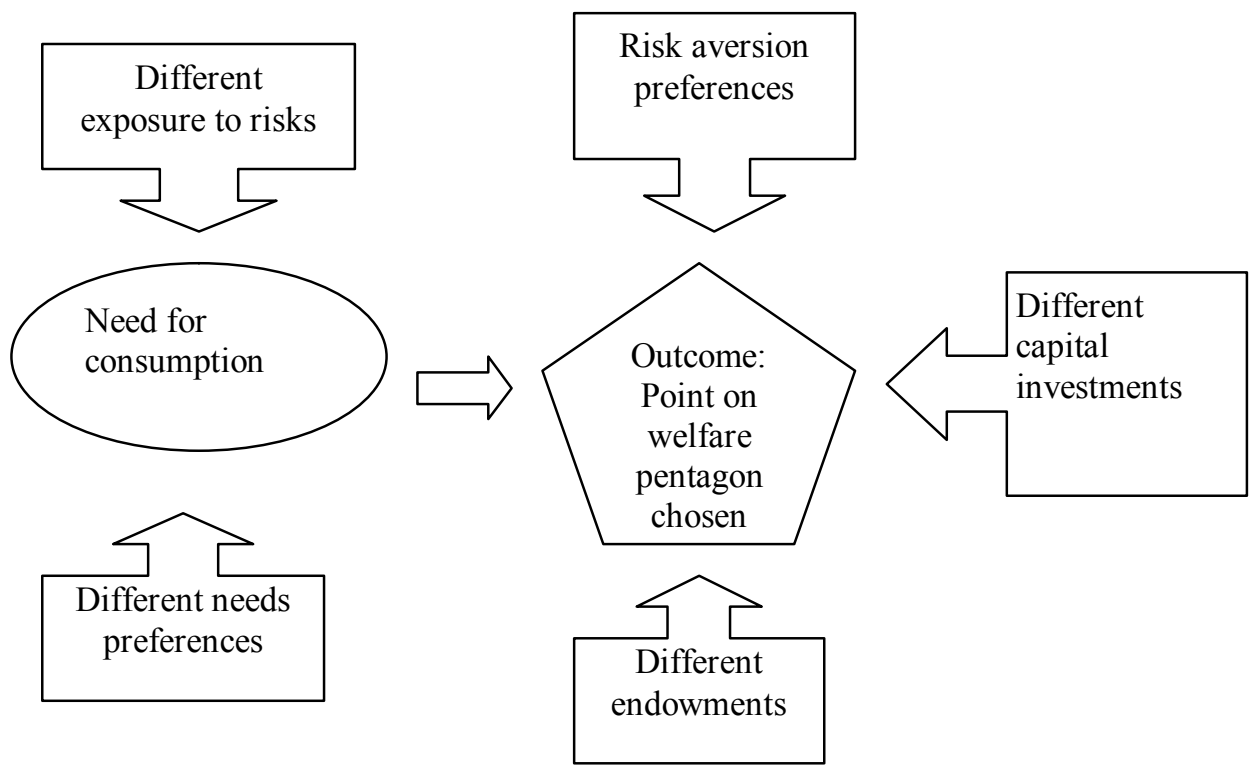

The results of the differences in the economic activities of households (production points in the welfare pentagon space) lead to an income distribution and a corresponding income distribution. In that distribution, some households can satisfy their needs and smooth consumption and some others are "poor" in the sense that they have not enough means to guarantee that their needs are always satisfied.

\subsubsection{Migration as a livelihood portfolio decision}

Within the above framework, "migration" is one of the options in the livelihood portfolio decisions of households. It should be, however, noted that it is a very peculiar one, since it implies that individuals or households (at least partially) 
change from one welfare pentagon to another one: they literally move from the institutions of one welfare pentagon to the institutions of another one. Given what has been said about all forms capital to be built up in order to be able to mobilize an institution within a given welfare pentagon, the migration decision is of a very specific nature within the livelihood portfolio options. Depending on the physical and social distances to be traveled to realize the migration, the shifts from one welfare pentagon to another may be dramatic or marginal. At least the analysis should take the existence of 2 welfare pentagons into consideration: the welfare pentagon in the sending country and the one in the receiving country.

The sending country welfare pentagon

When it comes to understanding why some people migrate and others do not, we now have defined a first element: people living in "poor" households (meaning not able to generate income or to smooth consumption in order to fulfill needs) have an incentive to consider moving from one place to another area or country. In that sense we follow classic economic migration theories that predict that "differences in net economic advantages ... are the main cause of migration" (Harris \& Todaro, 1970; Hicks, 1932; Mincer, 1978). Our theoretical framework is richer in the sense that it relates migration not only to maximizing earning capacities in various geographical contexts but interprets migration as part of livelihood portfolio decisions which also takes into consideration endowments and investments (and the resulting assets) into more than one welfare pentagon channel (this brings the framework closer to Sjastaad's human capital theory; 1962).

However, a lot of people might have the incentive to migrate in economic terms, but actually do not. Many publications in migration studies point to the observation that there seems to be a general preference for staying in the location in which the person lives (DaVanzo, 1981; Faist, 1997; Fischer, Martin, \& Straubhaar, 1997; Haug, 2000). In the framework presented here, this preference (or "the value of immobility linked to the accumulation of location specific advantages" as Fischer et al., 1997, called it) is explained by the access to the institutions that enable a household to generate income and smooth consumption in their home location. Access to (welfare pentagon) institutions are in turn explained by initial endowments at home and location-specific investments in economic, human and especially social capital (and its related sunk costs) that guarantee access to the channels of the welfare pentagon at home (DaVanzo, 1981). Thus the more capital endowments and capital investments are location specific, the less likely an individual or a household will migrate. This provides an additional explanation of why a relatively small number of people migrate compared to the number of people that might economically gain from migration.

The argument above can also be expressed in other terms: if the endowment-based access to the institutions of the welfare pentagon and the investments made into 
the channels of the welfare pentagon are interpreted as a measure for the degree of social inclusion of households, it can be said that the relatively high degree of social inclusion (at home) prevents most people from migrating. The more people are successfully embedded in their societies, the less likely they will migrate. As we will argue below, this does not imply that those who are socially excluded automatically have a higher propensity to migrate.

The self-selection of migrants is often linked to arguments explained in our framework as having access to the institutions and the assets within the welfare pentagon. The theory provides a systematic treatment of Kothari's contribution that explores the relationships between migration, staying put and poverty, especially emphasizing the role of social relations, processes of exclusion and "poverty-related capitals", (Kothari, 2003)10.

The welfare pentagon in the sending (home) country of households that we discussed so far provides potentially the first drive towards migration. Considering migration is triggered by a shortfall in income generating and consumption smoothing strategies for a household (in the sending country) leading to a negative gap between the needs that have to be fulfilled and the actual potential of the household to fulfill the needs immediately or in the future. Especially the argument that optimizing consumption smoothing possibilities rather than net immediate income differences are equally important, which is consistent with the New Economics of Labor Migration wherein riskdiversification arguments are prominent (Stark \& Bloom, 1985). The latter theory states that migration is not just aimed at maximizing income but rather at diversifying risks. This fits the consumption smoothing hypothesis: given household risk aversion and their endowment and investment possibilities in smoothing channels and assets, households cover the risk of future income shortage by seeking income generation in geographical areas wherein the shocks

\footnotetext{
${ }^{10}$ There is a large strand of literature specifically dealing with migrant selection, which is founded in the Roy Model (1951) tradition. Borjas's (1987) negative selection hypothesis based on the Roy Model discusses the selectivity of migrants and their sorting across destinations depending on cross-country differences in the returns to skills, hence in returns on investment made in human capital - the asset necessary to use the (labour) market channel to generate income. Many works have followed in this specific transition (Borjas, 1991, 1999; Borjas, Bronars, \& Trejo, 1992; Chiquiar \& Hanson, 2005; Grogger \& Hanson, 2008; McKenzie \& Rapoport, 2008; Moragas, 2008). Many selection studies have focused particularly on immigration to the United States, from Mexico (Caponi, 2006; Ibarraran \& Lubotsky, 2007; Mishra, 2007). Our theory complements this work by approaching the phenomenon of migrant selection from a different angle (the Welfare Pentagon).
} 
and the opportunities are uncorrelated to shocks and opportunities in their "home" area. $^{11}$

Paradoxically enough, embeddedness into the institutions of the welfare pentagon at home also provide the explanation for the fact that the poorest households seldom migrate ${ }^{12}$. In order to consider migration as a viable livelihood portfolio option some assets and some forms of capital are indeed needed. Households that are deprived of these assets or do not have enough capital relevant to the institutions cannot consider migration as a livelihood portfolio strategy. The assets needed for actively seeking to migrate are, among others, access to the travel options, funds to cover the costs of travel, time and human capital to be valued in labor markets, networks to help to select a destination and to assist integration in the destination country and the like (see table 1 for an elaboration). In general it can be said that households considering migration need trust and collaterals as forms of social capital to turn the option into a viable possibility.

Paying for the travel and documents assumes either having the money yourself or having access to the capital market where the funds can be borrowed: alternatively, having access to family members or network members who are able and prepared to give or lend money is a substitute (such as physical assets). Access to social capital in the form of membership organizations and networks that can provide information on how to arrange the documents and travel may play a role as well as. So do the sending country public authorities since they can impede, stimulate or facilitate the emigration (by providing legal documents and information). This means that households will only migrate when they have migration-efficient access to welfare pentagon channels that allow them to pay for the costs (formally or informally) and to provide assistance in deciding where to go, how to arrive and how to survive after arrival. Note that this applies to both legal (documented) and illegal (undocumented or irregular) migration. Assuming that access to social and financial capital and to markets (legal travel market, human trafficking market) are positively related to household endowments, it can be understood why less well endowed families ("poor" households) are less likely to migrate. This is consistent with the self-selection process assumed in some theories (Chiswick, 1999, 2000).

${ }^{11}$ The gains from migration are not defined in absolute terms but are defined by the consumption smoothing standards defined by the household itself. This assumption has to be made to allow high skilled migration and relates to the relative deprivation motives that underlie the New Economics of Labor Migration theory (Stark, 1991; Stark \& Bloom, 1985).

12 In poor and migration-prone Albania for example, the very poor do not migrate; the poorest $20 \%$ of the population in Albania are least likely to consider migration (Reilly, Litchfield, \& Castaldo, 2005)(see also Hagen-Zanker et al. 2009 for details). 
Discrimination in the sending country can act as a incentive to leave, but at the same time, it can also deprive the discriminated group of the essential capital/assets related to the welfare pentagon channels that allows them to migrate or even to consider migration as an option (e.g. because they cannot get the necessary documents or they lack access to the capital market or a sympathetic network - social capital). Access to social capital and the availability of family and friends also reduces the transaction costs of migration.

This is clearly only one part of the story; within the livelihood portfolio framework at least another welfare pentagon should be considered; that of the migrant in the receiving country. The latter is important since it plays a role in shaping the decisions (where) to move and the decisions to stay, move on or return.

\subsubsection{The receiving country welfare pentagon}

The perception of the income generating possibilities and the consumption smoothing potentials in the receiving country is of crucial importance when explaining whether people actually migrate. The analysis of the livelihood portfolio options within the welfare pentagon of households, once they have migrated into the receiving country, is also necessary to explain why people remain in the receiving country or why they eventually return to the original sending country (or migrate to a third country).

The simultaneous relevance of the welfare pentagon in the sending and the receiving country is an element that is found (at least implicitly) in an important part of the migration literature. Already in early contributions of Sjastaad (1962) and Lee (1966) and even Ravenstein (1885) this link is found but also more recent studies point in that direction: Doreen Massey's (1993) "power-geometry", King's (1995) "social relations across space" and Harvey's (1989) "friction of distance" all need the linkage between the two pentagons.

While the (relative ${ }^{13}$ ) position of a household in the welfare pentagon of the sending country is important in providing both the incentives and the means to migrate, the expected position of the migrants in the welfare pentagon of the receiving country is important as it is expected that the household can be integrated into the new welfare pentagon. Household (members) will only migrate if their potential place in the welfare pentagon of the receiving country can at least be assessed. All migrants understand that immediately after migration the need for income generation and consumption smoothing in the new society will be extreme. This means that they either need to have direct access to the labor market (having a job) or access to other forms of funding provided by their own savings or by family- and network-members in either the sending and/or the receiving country.

\footnotetext{
${ }^{13}$ (Stark \& Taylor, 1991)
} 
Expectations about income generation possibilities and the consumption smoothing options open to the migrating households are positively influenced by the formal access to all the markets in the receiving country ranging from the labor market to the capital-, housing-, education-, health services- and insurance markets and by the availability of family members, networks and membership organizations open to migrants (including NGO's serving migrants). The public authorities in the receiving country play an important role as well; they define the legal access to the markets and the public goods but also to social protection arrangements. Families, networks, membership institutions and the public authorities provide the economic and social capital that is urgently needed by migrants immediately after migration to generate income and/or to smooth consumption. Informal welfare pentagon channels are often especially important; they reduce the migration risks, counteract information asymmetries and provide direct and indirect access to legal and illegal markets. There is a vast literature on the role of networks in shaping migration decisions all pointing in that direction ${ }^{14}$.

\section{Summarising}

To summarise there are three main mechanisms that influence the decision to migrate:

- the individual (household) is constrained in its ability to generate income and to smooth consumption below a level that it deems necessary to fulfill its needs in the sending country;

- the individual (household) has access to the welfare pentagon institutions and assets that allows it to consider migration and to overcome the costs related to leaving the sending country;

- the individual (household) perceives to have access to the welfare pentagon institutions and assets in the receiving country that will enable it to generate income and smooth consumption after having migrated.

The combination of these mechanisms can explain why some (members of) households migrate while others do not. Figure 2.3 summarizes the migration decision process as depicted in the previous sections. Table 2.1 summarizes the assets and forms of capital needed in the 2 welfare pentagons.

\footnotetext{
${ }^{14}$ See (Bauer, Lofstrom, \& Zimmermann, 2000; Bauer, Pereira, Vogler, \& Zimmermann, 2002; Boyd, 1989; Faist, 1997, 2000; Fawcett, 1989; Gurak \& Caces, 1992; Heering, Van Der Erf, \& Van Wissen, 2004; Koser, 1997; Koser \& C.Pinkerton, 2002; Martin \& Taylor, 1996; Douglas Massey, 1988, 1990; Douglas Massey et al., 1993; Ritchey, 1976; Wilpert, 1992). See also see: (Dolfin \& Genicot, 2006 and Orrenius, 1999).
} 


\section{Figure 2.3: The migration decision making process}

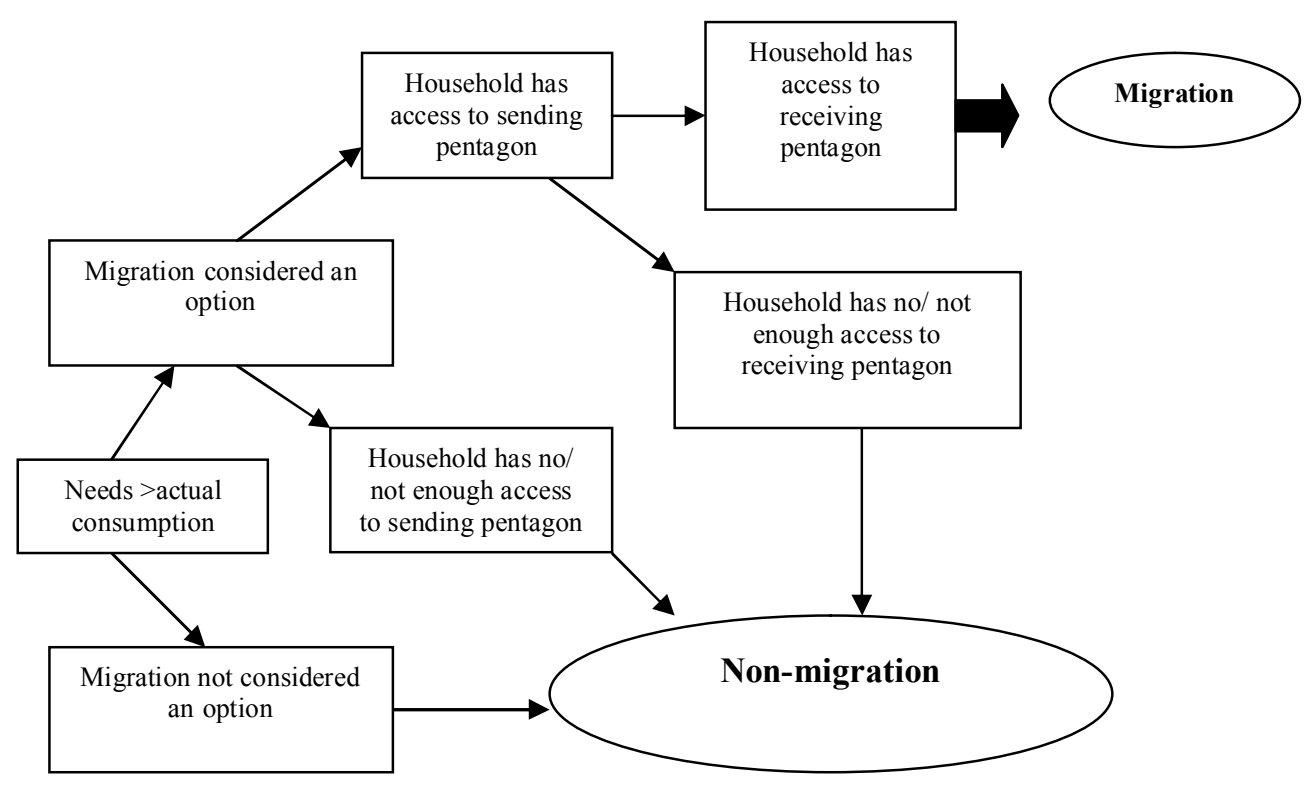

\subsubsection{Return migration or beyond initial migration}

The decision to migrate is only partially discussed when looking at the initial decision only ${ }^{15}$. For the analysis of the decision to stay in the receiving country, to return to the original sending country or to migrate to a third country, the livelihood portfolio - welfare pentagon framework is useful as well. The channels, institutions, assets and mechanisms involved in these decisions mirror their equivalents in the initial decision to migrate, but are not exactly the same.

After having arrived in the destination country every migrant or migrant household has permanently the choice to stay, to return to their country of origin or the move on to a third country. Again the welfare pentagons in at least 2 countries and the related institutions and assets play an important role. The first issue is of course whether the migrated household can satisfy its basic needs. These are again the basic needs as defined by the household itself. Nevertheless, an

\footnotetext{
${ }^{15}$ This is especially important when exploring the feasibility of public policy regarding migration (especially intentions to stimulate circular migration): the analysis of the decision to stay in the receiving country or to return to the sending country should be taken into consideration.
} 
absolute element plays a role in the decisions as well in the sense that migrants and their families should at least be able to survive in the receiving country. There is, however, a complicating issue. Migration might have been undertaken not only to improve the (relative) income position of the migrating person/household but also to improve the living conditions of the children/family/friends that were left behind in the country of origin. Many migrants are expected to send remittances back to the sending or home country. This implies de facto that the earnings or the income generated in the receiving country have to satisfy both the needs of the migrant him/herself in the receiving country and the expected remittances to be sent to the country of origin.

Whether a migrant is able to satisfy this total need depends on his/her own definition of what is needed in the receiving country and what needs to be sent home. If a migrant is not able to satisfy both parts of the need, he or she would have a strong incentive to leave the receiving country.

However, a big role is played by the receiving community in the receiving country. This community provides (temporary) support to migrants in order to make ends meet (not necessarily by money transfers, but also by assistance in kind). Moreover, the network of the migrant in the receiving country may also reduce the emotional costs of being abroad and living far away from the family and the place/country where one is born. The network of the migrant community will also provide support in bureaucratic ways or by arranging access for the migrant to banks, loans and most importantly public goods such as health services, school for the children, etc. However, there is also an additional element related to the behavior of the migrants towards the institutions of the welfare pentagon in the receiving country. As was the case in the home country, migrants have to build up all sorts of capital and assets in the new receiving welfare pentagon in order to maximize their income generating capacity and to optimize their consumption smoothing abilities. By doing that, they will get more socially included into the receiving country and thus on the one hand create better opportunities but on the other hand making also sunk costs reducing their incentives to (re)migrate again. In the end, embeddedness in the receiving country welfare pentagon provides incentives to stay, raises opportunity costs to leave and create the same inertia that explained while most people in the end do not migrate to begin with. 


\section{Table 2.1: Consumption smoothing channels for migration decision to move}

\begin{tabular}{|c|c|c|}
\hline \multirow{2}{*}{$\begin{array}{l}\text { Institutional } \\
\text { counterpart }\end{array}$} & \multicolumn{2}{|c|}{ Assets needed in } \\
\hline & $\begin{array}{l}\text { Sending country } \\
\text { Pentagon } 1\end{array}$ & $\begin{array}{l}\text { Receiving country } \\
\text { Pentagon } 2\end{array}$ \\
\hline Markets & $\begin{array}{l}\text { Access to } \\
\text { - Traffic market (legal, illegal) } \\
\text { - Financial markets (assets) } \\
\text { - Labor (time, skills, competences) }\end{array}$ & $\begin{array}{l}\text { - Access to labor market } \\
\text { Legal and illegal } \\
\text { - Access to capital market } \\
\text { - Access to housing } \\
\text { - Access to insurance } \\
\text { - Integration } \\
\text { - Cultural market }\end{array}$ \\
\hline Families & $\begin{array}{l}\text { Access to family ties (social capital) } \\
\text { for } \\
\text { - Informal borrowing } \\
\text { - Support } \\
\text { - Representing family }\end{array}$ & $\begin{array}{l}\text { Social capital for } \\
\text { - Informal borrowing } \\
\text { - Support }\end{array}$ \\
\hline Networks & $\begin{array}{l}\text { Access to social capital for } \\
\text { - Informal borrowing } \\
\text { - Information } \\
\text { - Support }\end{array}$ & $\begin{array}{l}\text { - Access to social capital } \\
\text { - Support to start } \\
\text { - Facilitate access to markets } \\
\text { - Friendship, } \\
\text { - community }\end{array}$ \\
\hline $\begin{array}{l}\text { Membership } \\
\text { organizations }\end{array}$ & $\begin{array}{l}\text { Access to social capital in migration } \\
\text { organizations }\end{array}$ & $\begin{array}{l}\text { - Access to social capital } \\
\text { - Access to cultural capital } \\
\text { - Religion } \\
\text { - Cultural life }\end{array}$ \\
\hline Public Authorities & $\begin{array}{l}\text { - Permission to leave } \\
\text { - Legal documents } \\
\text { - Incentives to leave } \\
\text { - Information }\end{array}$ & $\begin{array}{l}\text { - Permission to enter and or to work } \\
\text { - Access to public goods } \\
\text { - Access to social security } \\
\text { - Taxes } \\
\text { - Social security contributions }\end{array}$ \\
\hline
\end{tabular}

Again this is not the end of the story: even when migrants decide to go back to the country of origin, they will have to take their expected integration into the welfare pentagon of the original home country into consideration. Whether a migrant actually has the option to go back is dependent on the remaining richness of his or her endowment in the welfare pentagon of the original sending country and on the investments in all sort of capital made in the originally sending country made while being abroad. The more the migrant still has a family, a social network and membership organizations, not to speak of access to the labor market (and other markets), the more he or she has the option to go back one day. The weaker the network ties and the lower his or her social, human, political and other capital that is available (invested) in the home country, the less likely people will want to go back, even if the economic incentive is high by the fact that basic needs cannot be satisfied in the receiving country or by the fact that their new potential income position in the home country would be more favorable then before the initial 
migration. Of course, migrant households or individuals are not just subject to degrading social inclusion into their sending country welfare pentagons, they are active participants in that process. Migrant households not only have to invest in social and economic capital in their new receiving welfare pentagons, but can also decide to build up or maintain capital and assets in their original sending countries. By doing so they increase their options for returning to their home country. This introduces more recent considerations that focus on the transnational activities of migrants and try to analyze the impact of modern communication- and transport technologies on the (investment) behavior of migrants (Vertovec (2009), Mazzucato (2008) and Khagram and Levitt (2008)). Given the theoretical considerations explained in this paper, it is clear that investment in this context in all types of capital and assets are important.

In short, the degree of embededness in the welfare pentagon of the receiving country and the related sunk costs will act as an impediment to remigrate; the degree of embededness in the home country welfare pentagon act as an incentive to return. The net-outcome is of the two counteracting forces is an empirical question and depends on the public policies and the economic prospects in both the receiving and the home (initially sending) country and on the investment behavior in the originally sending country. Policy makers who strongly believe in the possibility of controlling migration implicitly believe that public policy can change the incentives in all or in some the stages of the process. At the stage of the initial migration from the sending country, the optimistic policy maker aiming for selective migration into the receiving country assumes that public policy in the receiving country can set the incentives for certain groups in the sending country to encourage migration while discouraging other groups. The equally optimistic policy maker in the receiving country aiming at stimulating return and circular migration, assumes that the incentives can be set to stimulate people to emigrate out of the receiving country back to the home (initially sending) country. Whether this policy view is overoptimistic depends on not only on economic incentives (including the relevant economic prosperity of the two countries involved ${ }^{16}$ ) but

\footnotetext{
${ }^{16}$ It should be noted that the theoretical framework can and should be studied in its dynamic properties. It is clear that over time economies grows and it is likely that the economy of some of the sending countries will catch up. This implies that economic growth prospects in the sending country may become relative better than in the receiving country thus providing an incentive for migrants to return. It is also clear that relative position in the (income) distribution of the migrants in the welfare pentagon institutions of the receiving countries gets better as they stay longer and get better integrated. This may act as a disincentive to re-migrate; on the other hand higher income in the receiving country would mean an even relative higher position in the sending country after return thus acting as incentive to move back to the country of origin. As said above, the net effect of all this forces is an empirical question that deserves further research.
} 
also on the relative degrees of embededness of the migrants in the four relevant welfare pentagons: the pentagon in the sending country prior to the initial migration, the pentagon in the receiving country at the time of the initial migration decision, the pentagon of the receiving country after the initial migration and the pentagon of the home (initial sending) country at the time of the eventual remigration decision.

We do not have sufficient data to answer the empirical questions raised above; we even do not have enough detailed data to allow the full empirical analysis of the initial migration decisions along the lines depicted in the first part of this paper ${ }^{17}$. In the second part of the paper, we use available data for 2 countries (Albania and Moldova) to explore to what extent we can find the empirical indications that support or contradict the theoretical framework as explained above ${ }^{18}$.

${ }^{17}$ At the Maastricht Graduate School of Governance a large research projects has been recently (2009) started in collaboration with the Ministry of Foreign Affairs in the Netherlands aiming at collecting the data to analyze the mechanisms depicted in this framework.

${ }^{18}$ For simplicity's sake, we ignore in this paper problems of endogeneity relating livelihood portfolio options and choices to inequalities between individuals in initial endowments in all forms of capital. It is far from excluded, however, that constraints met by individuals and choices made by individuals are related to their position in the income distribution (or in the distribution of capitals in the welfare pentagons channels). The degree of risk exposure of households might not just be randomly distributed among households in a particular society but may be positively biased towards the "poorly endowed" households, meaning that poor households run higher risks to be confronted with "bad luck" for example because they are concentrated in neighborhoods with a higher than average propensity to e.g. crime, physical damage due to earthquakes, flooding, drought, bad harvests and health hazards due to "bad conditions" in general. As indicated, individuals and households set their needs level themselves; besides the basic conditions to survive, household can choose the need level that needs to be realized at time " $t$ " and guaranteed by consumption smoothing in the future. Moreover, individuals and households define themselves the actual degree of risk aversion deemed acceptable. If the definition of needs and levels of risk aversion are related to one's position in the income distribution, than households with a low level of endowment in terms of access to the welfare pentagon channels may adopt a behavior that traps them into this low welfare level in two ways. Firstly, they choose an ambition level which is lower than potentially could be reached and secondly they choose consumption smoothing strategies that are less effective. Moreover, they may be confronted with higher risks exposure and with more investment constraints in all forms of capital. The endogeneity in terms of channel choices, investment constraints and risk exposure do not change the theory, but complicates it and make both empirical analyses and policy interventions more troublesome.

In terms of migration, the endogeneity is consistent with the theoretical and empirical findings that the poorest households in a society do not migrate, that the relative position of a household in the income distribution rather than the absolute income position of households defines the propensity to migrate (Doreen Massey, 1993; Stark \& Taylor, 1991) and that the poorest countries of the world are not responsible for the largest migration flows. 


\subsection{Empirical exploration of the livelihood portfolio theory of migration: Albania and Moldova}

This section uses data from standard households surveys for Albania and Moldova $^{19}$ to explore the relevance of the welfare pentagon institutions in explaining differences between migrants or more correctly households with migrants and households without migrants. It is clear that these data are not collected to test the livelihood portfolio theory. Many variables that would reflect the access to, endowment in- and investments in the institutions of the welfare pentagon are simply not available. The following sections therefore explore the data as they are available with two underlying questions: firstly, what are the straightforward relationships between the indicators for embeddedness into the welfare pentagon and the migration status of a household?; and secondly, what can be learned from the analysis in order to design a survey instrument that would enable the researcher to test the theoretical framework. The section uses simple methodologies (descriptive statistics and probit).

19 We use data from household surveys in the migrant sending country as the basis of our
empirical analysis. For Albania, we use the Living Standards Measurement Survey (LSMS)
collected by Albania's statistical agency INSTAT in 2005, with technical assistance of the
World-Bank, which is representative on a national level and has a sample of 3640
households. This is a standard household survey and includes extensive modules on
education, migration, consumption, labour etc. We compliment the household level data
with information from a detailed community questionnaire in the communities of the
households, which was collected at the same time. A migrant is defined as anyone who has
been abroad for at least one month.

For Moldova we use the CBSAXA 2006 Survey. The opinion research company CBSAXA conducted this migration household survey for the International Organization for Migration in Moldova. One important purpose of the CBSAXA survey is to compare households with migrants to those without. Therefore, the survey was designed to be representative of Moldovan households at the national level (excluding Transnistria), for each major geographic region (North; Center; South; Chisinau), and for each major type of locality (large cities: Chisinau and Balti; other towns; villages). The total number of households interviewed was close to 4,000, resulting in a sampling error of approximately 3 percentage points for the share of households with migrants. A migrant is defined as anyone who has been abroad for at least three months since 1991. Member ship of the migrant in the household is defined by the household answering the questionnaire. 


\subsubsection{Descriptive statistics}

The following tables show whether there are significant differences in access to the different parts of the Welfare Pentagon for households that have migrants among their members and those that do not. First, Table 2.2 explores the differences between households with migrants and households without in variables with no direct relationship to the welfare pentagon channels; these variables will be used later as control variables in the probit regressions ("yes" means there is a migrant in the household and "no" means there is no migrants in the household, while "total" is the average of the variables for both categories). According to table 2.2, differences in age are significant; households with migrants are younger than average age in general. There are also significantly more males and married individuals represented in the migrant population than in the non-migrant population. There are significanlty more urban households with migrants in Moldova, while this difference is not significant in Albania. Most households are headed by males in both countries, slighly more households are headed by male migrants than non-migrants in Albania while, this is the oposite case in Moldova. The age of the household head is also slightly lower for migrant housholds and more household heads are maried in migrant households and have more children.

Table 2.2 Differences between migrants and non-migrants: non- welfare pentagon or control variables

\begin{tabular}{|c|c|c|c|c|c|c|}
\hline \multirow[b]{2}{*}{ Migrant } & \multicolumn{3}{|c|}{ Albania } & \multicolumn{3}{|c|}{ Moldova } \\
\hline & Yes & No & Total & Yes & No & Total \\
\hline \multicolumn{7}{|l|}{ Individual level variables } \\
\hline Age & $39.84^{* * *}$ & $42.71^{* * *}$ & 42.42 & $35.76^{* * *}$ & $42.49^{* * *}$ & 41.44 \\
\hline Age squared & $1717.12^{* * *}$ & $2169.67^{* * *}$ & 2125.31 & $1390.47^{* * *}$ & $2140.92^{* * *}$ & 2085.05 \\
\hline Male & $0.88^{* * *}$ & $0.42^{* * *}$ & 0.46 & $0.60^{* * *}$ & $0.44^{* * *}$ & 0.46 \\
\hline Married & $0.85^{* * *}$ & $0.67^{* * *}$ & 0.69 & $0.70^{* * *}$ & $0.63^{* * *}$ & 0.64 \\
\hline \multicolumn{7}{|l|}{$\begin{array}{l}\text { Household level } \\
\text { variables }\end{array}$} \\
\hline Urban & 0.48 & 0.47 & 0.47 & $0.38^{* * *}$ & $0.28^{* * *}$ & 0.36 \\
\hline Household head male & $0.95^{* * *}$ & $0.93^{* * *}$ & 0.93 & $0.80^{* * *}$ & $0.83^{* * *}$ & 0.80 \\
\hline Household head age & $50.04^{* * *}$ & $53.15^{* * *}$ & 52.84 & $47.40^{* * *}$ & $52.54^{* * *}$ & 51.75 \\
\hline & 0.92 & 0.91 & 0.91 & $0.84^{* * *}$ & $0.79^{* * *}$ & 0.80 \\
\hline $\begin{array}{l}\text { Number of children in } \\
\text { household }\end{array}$ & $1.23^{* * *}$ & $1.02^{* * *}$ & 1.04 & $0.81^{* * *}$ & $0.55^{* * *}$ & 0.59 \\
\hline $\begin{array}{l}\text { Number of obs for } \\
\text { individulas }\end{array}$ & 996 & $10,, 748$ & 11,740 & 1,798 & 9,785 & 11,583 \\
\hline
\end{tabular}

Stars indicate whether the mean for each group is statistically different across groups ( ${ }^{*}$ significant at $10 \%$; ${ }^{* *}$ significant at $5 \%{ }^{* * *}$ significant at $1 \%$ )

Source: Own calculation based on ALSMS 2005 and CBSAXA 2006 
In the next set of tables we explore the differences between households with- and households without migrants in the light of the five corners/channels whitin the welfare pentagon. This exploration is obviously limited by the data that are available in the household surveys for the two countries under study.

Table 2.3 provides the results for proxies that reflect family institutions. The variables tell us something about family size, the scope of the extended family members network and about the wealth of the household in terms of the Morris index ${ }^{20}$. Families with migrants are significantly smaller in Albania and Moldova. Families without migrants in Albania also have larger extended families (difference not significant). So on the one hand this is unexpected, because one would expect that these households can rely on their extended families for consumption smoothing and so do not need to migrate. On the other hand, extended families give access to migration as a consumption-smoothing strategy through network effects. It is hotly debated in the migration literature whether higher wealth or income are a cause or an effect of migration. With descriptive statistics we will not be able to draw any conclusions on causality but just give an initial look at the variable. The household's Morris score index, which should be unaffected by migration (see footnote below) is significantly lower for migrants. This could mean that migrants can again not rely on their families as much as nonmigrants or that there is more need for them to go abroad.

Table 2.3 Differences between migrants and non-migrants: Family institutions

\begin{tabular}{l|ccc|ccc}
\hline & \multicolumn{3}{|c|}{ Albania } & \multicolumn{3}{c}{ Moldova } \\
\hline Migrant & Yes & No & Total & Yes & No & Total \\
\hline Household size & $4.60^{* *}$ & $4.71^{* *}$ & 4.7 & $3.69^{* * *}$ & $4.28^{* * *}$ & 3.79 \\
Number of extended family members (siblings, & & & & & & \\
adult children) & 8.8 & 8.84 & 8.84 & & & \\
Morris score index reference & $0.46^{* * *}$ & $0.56^{* * *}$ & 0.55 & $0.65^{* * *}$ & $0.82^{* * *}$ & 0.68 \\
\hline Number of observations & 996 & 10,748 & 11,740 & 1803 & 9899 & 11702 \\
\hline
\end{tabular}

Stars indicate whether the mean for each group is statistically different across groups ( ${ }^{*}$ significant at $10 \%$; ${ }^{* *}$ significant at $5 \%$; ${ }^{* * *}$ significant at $1 \%$ )

Source: Own calculation based on ALSMS 2005 and CBSAXA 2006

When trying to explore the differences between households with a migrant and those without in their access to market institutions, we use per capita household consumption, the level of education of the migrant, employment, farm activities and the availability of a bank in the community (Table 2.4). It should be noted that

\footnotetext{
${ }^{20}$ The Morris score index is a weighted asset index that weighs each asset owned by the household by the reciprocal of the number of households that own the asset (see Morris et al. 1999). For Albania we use the index for the year 1990, which means that it is unaffected by migration. In Moldova migration occurred very rapidly, so we assume that assets are still unaffected by migration.
} 
per capita consumption can be regarded as 'outcomes' of market processes rather than an indication of access to the market institution. However, the variable also reflects in the end whether access has been realised. Moreover, the direction of causality cannot be concluded from the table. In Albania we see that household expenditures of non-migrants are lower; it could be that households with migrants are richer (thus financing the costs of migration and providing access to a larger range of resources) and that non-migrants do not have access to funds to finance migration. It may also be the case that the migrant households are wealthier because they receive remittances from the migrant household member. In Moldova, on the other hand, we see that non-migrants come from significantly higher incomes, maybe because they had better access to market institutions at home and therefore did not need to migrate; that is to say, the degree of embeddedness of higher income household members in the markets at home made migration as a livelihood strategy less attractive.

We cannot draw clear conclusions on the selection patterns of migration with respect to the level of education. In Albania, individuals with secondary and vocational education are more likely to migrate and in Moldova it is people with primary and higher education. It is clear that people with higher and primary education do not seem to be well connected to the local labour market in Moldova, but for Albania the message is less clear. In that latter country, the highly educated are probably well connected at home, and it could be that lower-educated do not migrate due to other reasons, e.g. poverty. In Moldova, we see that non-migrants live in households with higher employment ratio. This could be an indication that members of migrant households did not have access to the domestic labour market and thus choose to migrate as a livelihood strategy. It could also be the case that migrant households do not work due to preferences (e.g. the wife left behind) and/or do not need to work on the labour market due to remittances received. In Albania, however, we see the opposite picture. Non-migrant household heads are less likely to be employed in agriculture in Albania; this implies that they have more access to other employment options. ${ }^{21}$ Albanian migrants are significanlty more likely to live in communities with a bank. Banks can play a role in financing migration, but also in transfering remittances to households. It is remarkable that the findings for Albania and Moldova are so different when it comes to access to market institutions. Moreover, it is not easy to interpret the differences in a meaningfull unidirectional way. This indicates that either the data are not

\footnotetext{
${ }^{21}$ This finding seemingly contradicts Miluka et al. (2007) who, also using the ALSMS dataset, find that migration of a household member has a negative impact on agricultural effort, measured by total hours spent on agriculture by all family members. However, we look at whether the household head works in agriculture and find that household heads of migrant families are more likely to be employed on a farm. This result is compatible with households as a whole working less on farms due to remittances received.
} 
sufficiently precise to allow firm conclusions or that the theory is not sufficiently specified (or both). We will come back to that later.

Table 2.4 Differences between migrants and non- migrants: Market institutions

\begin{tabular}{|c|c|c|c|c|c|c|}
\hline \multirow[b]{2}{*}{ Migrant } & \multicolumn{3}{|c|}{ Albania } & \multicolumn{3}{|c|}{ Moldova } \\
\hline & Yes & No & Total & Yes & No & Total \\
\hline \multicolumn{7}{|l|}{ Individual leve l variables } \\
\hline Primary education & $0.42^{* * *}$ & $0.57^{* * *}$ & 0.56 & $0.14^{* * *}$ & $0.10^{* * *}$ & 0.13 \\
\hline Secondary education & 0.22 & 0.20 & 0.20 & $0.34^{* * *}$ & $0.39^{* * *}$ & 0.35 \\
\hline Vocational education & $0.27^{* * *}$ & $0.14^{* * *}$ & 0.16 & $0.29^{* * *}$ & $0.32^{* * *}$ & 0.29 \\
\hline University education & 0.09 & 0.08 & 0.08 & $0.21^{* * *}$ & $0.18^{* * *}$ & 0.2 \\
\hline Household head employed & $0.73^{* * *}$ & $0.67^{* * *}$ & 0.68 & $0.17^{* * *}$ & $0.41^{* * *}$ & 0.21 \\
\hline \multicolumn{7}{|l|}{ Household level varibles } \\
\hline $\begin{array}{l}\text { Monthly per capita } \\
\text { consumption US\$ }\end{array}$ & $76.57^{* * *}$ & $67.49^{* * *}$ & 68.38 & $98.12^{* * *}$ & $154.34^{* *}$ & 106.78 \\
\hline Household work ratio & $0.55^{* * *}$ & $0.50^{* * *}$ & 0.5 & $0.16^{* * *}$ & $0.38^{* * *}$ & 0.2 \\
\hline $\begin{array}{l}\text { Whether hhh working on } \\
\text { farm }\end{array}$ & $0.34^{* *}$ & $0.38^{* *}$ & 0.38 & & & \\
\hline $\begin{array}{l}\text { Whether bank is a possible } \\
\text { source of credit in this } \\
\text { community }\end{array}$ & $0.66^{* * *}$ & $0.61^{* * *}$ & 0.61 & & & \\
\hline Number of obs & $688-996$ & $\begin{array}{l}6,868- \\
10,748\end{array}$ & $\begin{array}{l}7,556- \\
11,744\end{array}$ & 1802 & 9,863 & 11,665 \\
\hline
\end{tabular}

Household work ratio looks at the employment status of all adult household members, including migrants

Stars indicate whether the mean for each group is statistically different across groups (* significant at $10 \% ;{ }^{* *}$ significant at $5 \%{ }^{* * *}$ significant at $1 \%$ )

Source: Own calculation based on ALSMS 2005 and CBSAXA 2006

Looking now at social networks, members of migrant households seem to be better connected in some ways: they have more friends and socialize more often (Table 2.5). The fraction of migrants in the local community is significantly higher for migrant- than non-migrant households in Albania. All in all, members of migrant households (at least in Albania) are significantly more likely to have access to migrant social networks. 
Table 2.5 Differences between migrants and non-migrants: social network institutions

\begin{tabular}{l|ccc|ccc}
\hline & \multicolumn{3}{|c|}{ Albania } & \multicolumn{3}{c}{ Moldova } \\
\hline Migrant & Yes & No & Total & Yes & No & Total \\
\hline Number of friends & $2.07^{* * *}$ & $1.79^{* * *}$ & 1.81 & & & \\
Number of times joined other people & $1.61^{* * *}$ & $1.29^{* * *}$ & 1.33 & & & \\
People can be trusted & 0.18 & 0.19 & 0.18 & & & \\
Fraction of individuals in community & & & & & & \\
who are international migrants (non- & & & & $0.06^{* * *}$ & $0.08^{* * *}$ & 0.07 \\
selfconstructed) & $0.12^{* * *}$ & $0.11^{* * *}$ & 0.11 & & & \\
Participated in communal activities & 0.1 & 0.1 & 0.1 & & & \\
Can get credit from friends etc in & & & & & & \\
emergency & 0.47 & 0.46 & 0.46 & & & \\
\hline Number of obs & 996 & 10,748 & 11,740 & 1,803 & 9,899 & 11,702 \\
\hline
\end{tabular}

Fraction of individuals in community who are international migrants is non-selfconstructed

Stars indicate whether the mean for each group is statistically different across groups ( ${ }^{*}$ significant at $10 \%$;** significant at $5 \%$; *** significant at $1 \%$ )

Source: Own calculation based on ALSMS 2005 and CBSAXA 2006

So far we have looked at social network institutions, which measure informal connections. Next, we look at membership of associations; this measures more formal networks and may have higher entry thresholds and thus be less accessible. Only the Albanian dataset has variables that may be used as indicators for the access of the households and individuals to membership institutions and to public authorities, illustrated in Tables 2.6 and 2.7 below. Table 2.6 shows that Albanian migrants belong to households that belong to more groups and live in communities with a higher number of membership associations, indicating that they have more access to formal and informal migration networks.

Table 2.6 Differences between migrants and non-migrants: Membership association institutions

\begin{tabular}{l|ccc}
\hline & \multicolumn{3}{|c}{ Albania } \\
\hline Migrant & Yes & No & Total \\
\hline Number of groups household belongs to & $0.38^{* *}$ & $0.33^{* *}$ & 0.34 \\
Number of community organisations in community & $5.47^{* * *}$ & $4.98^{* * *}$ & 5.03 \\
\hline Number of obs & 947 & 10,207 & 11,154 \\
\hline
\end{tabular}

Stars indicate whether the mean for each group is statistically different across groups ${ }^{*}$ significant at $10 \%{ }^{* *}$ significant at $5 \%$; $^{* * *}$ significant at $1 \%$ )

Source: Own calculation based on ALSMS 2005 and CBSAXA 2006

From Table 2.6 it can be seen that migrants live more often in communities with public lighting, public phones, mail, a police station. From a welfare pentagon perspective, one would expect that migrants from non-functioning communities 
would be more likely to migrate, but this does not seem to be the case, at least in terms of infrastructure. In terms of receiving a public transfers, migrants are more likely to come from households that do not receive public transfers, i.e. they need to smooth income in other ways.

Table 2.7 Differences between migrants and non- migrants: Public authority institutions

\begin{tabular}{l|ccc}
\hline & \multicolumn{3}{|c}{ Albania } \\
\hline Migrant & Yes & No & Total \\
\hline Household receives public transfers & $0.50^{* * *}$ & $0.59^{* * *}$ & $0.50^{* * *}$ \\
Community has public lighting & $0.60^{* *}$ & $0.56^{* *}$ & $0.60^{* *}$ \\
Community has piped water & 0.8 & 0.78 & 0.8 \\
Community has sewage/ drains & 0.6 & 0.58 & 0.6 \\
Community has garbage collection & 0.59 & 0.56 & 0.59 \\
Community has public phones & $0.52^{* *}$ & $0.49^{* *}$ & $0.52^{* *}$ \\
Community has mail & $0.55^{* *}$ & $0.51^{* *}$ & $0.55^{* *}$ \\
Community has police station & $0.45^{* *}$ & $0.41^{* *}$ & $0.45^{* *}$ \\
\hline Number of obs & 994 & 10,724 & 11,718 \\
\hline
\end{tabular}

Stars indicate whether the mean for each group is statistically different across groups $\left({ }^{*}\right.$ significant at $10 \% ;{ }^{* *}$ significant at $5 \%{ }^{* * *}$ significant at $1 \%$ )

Source: Own calculation based on ALSMS 2005 and CBSAXA 2006

Summarizing the information in tables $2.2-2.7$ is nearly impossible. It should be noted that the data are largely defective in measuring what the welfare pentagon channels are trying to capture. Moreover, when data are available to point in many different directions when it comes to interpretation; we will discuss this at the end of this chapter again. In the next section we first look at the combined effect of the most important variables just discussed.

\subsubsection{Probit estimates}

We ran two probit estimations on the probabilty to be a migrant. One regression includes the same variables for Albania and Moldova and the results are listed in Table 2.8 below. The second regressions includes a wider range of explanatory variables for Albania only, since we have more detailed data available for that country (Table 2.9). Our variables of interest are proxies that could represent some of the corners of the welfare pentagon. We also include some variables to control for demographic differences between the individuals (age, gender, marital status, urban/ rural location of household, etc.). 
Table 2.8 Probit analysis on the probability to be a migrant: Albania and Moldova

\begin{tabular}{|c|c|c|c|c|c|}
\hline & & \multicolumn{2}{|c|}{ Albania } & \multicolumn{2}{|c|}{ Moldova } \\
\hline $\begin{array}{c}\text { Welfare } \\
\text { pentagon } \\
\text { corner }\end{array}$ & & Coefficient & $\begin{array}{c}\text { Robust } \\
\text { standard error }\end{array}$ & Coefficient & $\begin{array}{c}\text { Robust } \\
\text { standard } \\
\text { error }\end{array}$ \\
\hline \multirow[t]{9}{*}{ Control } & Age & $0.12^{* * *}$ & 0.02 & $0.143^{* * *}$ & 0.024 \\
\hline & Age2 & $-0.00^{* * *}$ & 0 & $-0.002^{* * *}$ & 0 \\
\hline & Gender male & $1.25^{* * *}$ & 0.06 & $0.408^{* * *}$ & 0.032 \\
\hline & Married & $0.45^{* * *}$ & 0.1 & -0.046 & 0.057 \\
\hline & $\begin{array}{l}\text { HH lives in urban } \\
\text { area }\end{array}$ & -0.04 & 0.06 & $-0.121^{* * *}$ & 0.037 \\
\hline & $\mathrm{HHH}$ age & 0 & 0 & -0.001 & 0.002 \\
\hline & HHH male & 0.19 & 0.17 & $-.136^{* *}$ & .054 \\
\hline & HHH married & $-0.29^{*}$ & 0.16 & $-0.092^{*}$ & 0.051 \\
\hline & \# Children in $\mathrm{HH}$ & $0.05^{*}$ & 0.03 & -0.029 & 0.025 \\
\hline \multirow[t]{3}{*}{ Family } & $\mathrm{HH}$ size & $-0.08^{* * *}$ & 0.03 & $0.075^{* * *}$ & 0.013 \\
\hline & Morris score index & 0.15 & 0.21 & $0.055^{* *}$ & 0.024 \\
\hline & Morris score index 2 & 0.19 & 0.24 & -0.004 & 0.005 \\
\hline \multirow[t]{5}{*}{ Market } & Secondary education & 0.04 & 0.06 & $0.112^{*}$ & 0.070 \\
\hline & Vocational education & $0.15^{* * *}$ & 0.06 & $0.212^{* * *}$ & 0.072 \\
\hline & Higher education & -0.08 & 0.09 & 0.084 & 0.078 \\
\hline & HH work ratio & $0.17^{*}$ & 0.1 & $1.410^{* * *}$ & 0.075 \\
\hline & HHH employed & $-0.17^{* *}$ & 0.07 & 0.028 & 0.047 \\
\hline \multirow[t]{8}{*}{$\begin{array}{c}\text { Social } \\
\text { networks }\end{array}$} & $\begin{array}{l}\text { Community's migrant } \\
\text { share } 11-20 \%\end{array}$ & $0.24^{* * *}$ & 0.05 & $0.156^{* * *}$ & 0.040 \\
\hline & $\begin{array}{l}\text { Community's migrant } \\
\text { share }>21 \%\end{array}$ & $0.49^{* * *}$ & 0.08 & $0.388^{* * *}$ & 0.073 \\
\hline & Constant & $-4.21^{* * *}$ & 0.38 & $-4.181^{* * *}$ & 0.378 \\
\hline & $\begin{array}{l}\text { Number of } \\
\text { observations }\end{array}$ & 10393 & & 11334 & \\
\hline & Pseudo R2 & 0.2391 & & 0.2000 & \\
\hline & $\begin{array}{l}\text { McKelvey \& } \\
\text { Zavoina's R2 }\end{array}$ & 0.239 & & 0.536 & \\
\hline & Loglikelyhood ratio & 1479.862 & & 1966.450 & \\
\hline & $\begin{array}{l}\text { Loglikelihood } \\
\text { probability }\end{array}$ & 0.000 & & 0.000 & \\
\hline
\end{tabular}

Albania: results clustered by households

Base: Migrant has primary school education; community has a migrant share $0-10 \%$

${ }^{*}$ significant at $10 \%$;* significant at $5 \%$; ${ }^{* *}$ significant at $1 \%$ 
The first interesting result is that signs and significance of different Welfare Pentagon explanatory variables differ quite considerably between Albania and Moldova. The measure of fit variables indicate that the regression for Albania seems to be a slightly better fit.

In Albania we see some evidence for the family-, market- and social network institutions playing a role in migration decisions. Migrants from larger households are less likely to migrate, while the Morris index is insignificant (family corner). Only migrants with vocational education are more likely to migrate, as already shown in the descriptive statistics; migrants with secondary and higher education seem to have some access to the domestic labour markets. More household members being employed also means that someone in the household is more likely to be a migrant, while individuals living in households with an employed head are less likely to migrate. The higher the share of migrants in the community, the more likely someone is to be a migrant, highlighting the importance of migrant networks. This last result is also shared by Moldova.

For Moldova, we also see that people coming from larger and wealthier households are more likely to be a migrant. In Moldova migrants with secondary and vocational education, are more likely to become migrants than people with primary education. Even more surprising, if more adults in the household are employed, a person is significantly more likely to become a migrant. Table 2.9 below gives the results of the probit regression of the probability to be a migrant using a wider range of variables that represent more corners of the Welfare Pentagon using Albanian data. 
Table 2.9 Probit analysis on the probability to be a migrant: Albania only with more extensive list of variables

\begin{tabular}{|c|c|c|c|}
\hline $\begin{array}{l}\text { Welfare pentagon } \\
\text { corner }\end{array}$ & & Coefficient & $\begin{array}{c}\text { Robust } \\
\text { Standard error }\end{array}$ \\
\hline \multirow[t]{9}{*}{ Control } & Age & $0.12^{* * *}$ & 0.02 \\
\hline & Age2 & $-0.00^{* * *}$ & 0 \\
\hline & Gender male & $1.25^{* * *}$ & 0.06 \\
\hline & Married & $0.42^{* * *}$ & 0.1 \\
\hline & $\mathrm{HH}$ lives in urban area & -0.12 & 0.1 \\
\hline & $\mathrm{HHH}$ age & 0 & 0 \\
\hline & HHH male & 0.21 & 0.17 \\
\hline & HHH married & $-0.31^{*}$ & 0.16 \\
\hline & \# Children in $\mathrm{HH}$ & $0.06^{* *}$ & 0.03 \\
\hline \multirow[t]{4}{*}{ Family } & HH size & $-0.09^{* * *}$ & 0.02 \\
\hline & Number of extended family members & 0 & 0.01 \\
\hline & Morris score index & 0.11 & 0.22 \\
\hline & Morris score index 2 & 0.2 & 0.24 \\
\hline \multirow[t]{6}{*}{ Market } & secondary education & 0.04 & 0.06 \\
\hline & vocational education & $0.15^{* * *}$ & 0.06 \\
\hline & higher education & -0.1 & 0.1 \\
\hline & HH work ratio & $0.20^{* *}$ & 0.1 \\
\hline & HHH employed & $-0.16^{* *}$ & 0.07 \\
\hline & $\begin{array}{l}\text { Whether bank is a possible source of credit in } \\
\text { this community }\end{array}$ & 0.03 & 0.06 \\
\hline \multirow[t]{6}{*}{ Social networks } & Number of friends & 0.02 & 0.01 \\
\hline & Number of times joined other people & $0.02^{* *}$ & 0.01 \\
\hline & Community's migrant share $11-20 \%$ & $0.28^{* * *}$ & 0.05 \\
\hline & Community's migrant share $>21 \%$ & $0.55^{* * *}$ & 0.09 \\
\hline & Participated in communal activities & -0.1 & 0.08 \\
\hline & Can get credit from friends etc in emergency & -0.04 & 0.05 \\
\hline \multirow[t]{2}{*}{$\begin{array}{l}\text { Membership } \\
\text { organisations }\end{array}$} & & -0.01 & 0.03 \\
\hline & $\begin{array}{l}\text { Number of community organisations in } \\
\text { community }\end{array}$ & $0.02^{*}$ & 0.01 \\
\hline \multirow[t]{9}{*}{ Public authorities } & Household receives public transfers & 0.08 & 0.05 \\
\hline & Community has public lighting & $0.17^{*}$ & 0.1 \\
\hline & Community has phone & $-0.26^{* *}$ & 0.13 \\
\hline & Community has mail & 0.02 & 0.09 \\
\hline & Community has police station & 0.12 & 0.08 \\
\hline & Constant & $-4.44^{* * *}$ & 0.39 \\
\hline & Number of observations & 9917 & \\
\hline & Pseudo R2 & 0.2455 & \\
\hline & McKelvey \& Zavoina's R2 & 0.246 & \\
\hline
\end{tabular}




\begin{tabular}{|l|l|c|c|} 
& Loglikelyhood ratio & 1445.170 & \\
& Loglikelyhood probability & 0.000 & \\
\hline
\end{tabular}

Base: Migrant has primary school education; community has a migrant share $0-10 \%$ Results clustered by household

${ }^{*}$ significant at $10 \% ;{ }^{* *}$ significant at $5 \%$; ${ }^{* *}$ significant at $1 \%$

The above results are mostly consistent with the descriptive statistics and the previous result with the reduced variable list. However, the measures of fit are barely improved, despite considerably more variables being included in the regression. This is because two corners of the welfare pentagon that are now included with some proxies do not seem to explain differences in the migration behaviour of houshold members.

None of the public provision variables are significant in explaining why people migrate (and public transfer switched sign compared to the descriptive statisics) once the family, market and social network corners of the welfare pentagon are taken into account. The same holds for the membership organisation variables.

For the family variables we again see that larger families are less likely to send a migrant, but the number of extended family members does not seem to influence this decision. The wealth of the household is again insignificant.

We again see that individuals with vocational education are more likely to migrate, apparently having higher employment posibilities abroad. However, a higher work ratio of household members and the household head working on a farm, now leads to more migration of the individual. Especially the former result is puzzeling, since one would expect a lower need to migrate, if the employment possibilities in Albania are good.

Finally, for the significant social network variables we see that individuals with stronger social networks (meeting people more often, having more migrants in the community) are more likely to migrate.

\subsection{Concluding remarks}

The livelihood portfolio theory of migration provides a rich framework that allows integrating a substantial number of the partial findings of previous empirical migration studies. It explains how variations in the levels of embeddedness (social inclusion) of individuals in the local economies explain why people migrate and why others do not. However, the comprehensive character of the theory is exactly 
its weakness when it comes to empirical testing. The theory assumes that very many variables may enter the equation, but exact predictions on the type of combinations of levels of embeddedness in the various institutions of the welfare pentagon that are important when triggering migration or when impeding migration, are complicated for three reasons.

Firstly, embeddedness in the various corners/channels of the welfare pentagon can be substitutes for each other; a lack of embeddedness in social networks for example may be counteracted by more embeddedness in family networks. The theory so far does not specify the combinations that are important, the critical levels that trigger behavior and the substitutions that lead to similar results in behavior.

Secondly, the relationship between the level of embeddedness in each channel of the welfare pentagon and the decision to migrate (in whatever direction) is neither necessarily linear nor monotonous; lower levels of embeddedness may lead to a lack of minimal integration that refrain people from migrating; much higher levels of embeddedness may lead to a level of integration in the local economy and community that makes migration equally unlikely; it may be exactly only critical values in the middle levels of embeddedness that leads to migration. Although the theory provides the flexibility in the specification, it does not (yet) provide predictions on the values of these critical parameters.

Thirdly, the empirical analysis requires a data set which exactly measures what the theory requires to be measured: namely observations and indicators on the level of embeddedness of individuals in the various institutions of the channels of the welfare pentagon. These data do not exist and should be collected for these purposes. The empirical exploration as offered in this chapter is not very satisfactory when trying to judge the plausibility of the theoretical framework; on the one hand some welfare pentagon institutions are found relevant, but on the other hand, others are clearly not. The data that are available are not really fit to the exercise. As part of the Dutch IS-Academy research project at the Maastricht Graduate School of Governance, data on the four relevant welfare pentagons (see above) will be collected. These data can be used as a source of inspiration to refine the theory by specifying the combination of the values of the parameters deemed important for explaining migration behavior. On the other hand, the data will also allow to test alternative hypotheses. The data limitations usually met in migration research are limiting the possibilities to test full structural models; many research outcomes are at best reduced form estimates often using proxy variables rather than adequate measurement. It is unlikely that a single new data base will solve all the related problems, but at least it will make the formulation of more precise predictions on migration behavior possible. The data limitations faced in this 
chapter are not different from those encountered in previous research based on partial theories; drawing conclusions, however, either on the old theories or on the new framework presented here, should be done with great care. 


\subsection{References}

Alessi, R. and A. Lusardi (1997). "Saving and income smoothing: Evidence from panel data." European Economic Review 41: 1251-1297

Bauer, T., M. Lofstrom, et al. (2000). "Immigration Policy, Assimilation of Immigrants and Natives' Sentiments towards Immigrants: Evidence from 12 OECD-Countries." Swedish Economic Policy Review, 7: 11-53.

Bauer, T., P. T. Pereira, et al. (2002). "Portuguese Migrants in the German Labor Market: Performance and Self-Selection." International Migration Review 36(2): 467-491.

Beegle, K., J. d. Weerdt, et al. (2008). "Migration and Economic Mobility in Tanzania: Evidence from a Tracking Survey." World Bank Policy Research Working Paper 4798.

Borjas, G. (1987). "Self-Selection and the Earnings of Immigrants." American Economic Review 77(4): 531-553.

Borjas, G. (1991). Immigration and Self-Selection. Immigration, Trade, and the Labor Market. J. Abowd and R. Freeman. Chicago, Chicago University Press: 29-76.

Borjas, G. (1999). The Economic Analysis of Immigration. Handbook of Labor Economics. O. C. Ashenfelter and D. Card. Amsterdam, North Holland: 1697-1760.

Borjas, G., S. G. Bronars, et al. (1992). "Self-Selection and Internal Migration in the United States." Journal of Urban Economics 32: 159-185.

Boyd, M. (1989). "Family and Personal Networks in International Migration: Recent Developments and New Agendas." International Migration Review 23(3): 638-670.

Caponi, V. (2006). "Heterogeneous Human Capital and Migration: Who Migrates from Mexico to the U.S.?" IZA Discussion Paper 2446.

Carletto, C., B. Davis, et al. (2006). "A Country on the Move: International Migration in Post-Communist Albania." International Migration Review 40(4): 767-785.

Carling, J. (2002). "Migration in the age of involuntary immobility: theoretical reflections and Cape Verdean experiences." Journal of Ethnic and Migration Studies 28(1): 5-42.

Chiquiar, D. and G. H. Hanson (2005). "International Migration, Self-Selection and the Distribution of Wages: Evidence from Mexico and the United States." Journal of Polical Economy 113: 239-281.

Chiswick, B. (1999). "Are immigrants favorably self-selected?" American Economic Review: 181-5. 
Chiswick, B. (2000). “Are Immigrants Favorably Self-Selected?” An Economic Analysis Migration Theory: Talking Across Disciplines. C. D. Brettel and J. F. Hollifield. New York, Routledge.

Coulon, A. D. and M. E. Piracha (2005). "Self-Selection and the Performance of Return Migrants: The Case of Albania " Journal of Population Economics 18(4): 779-807.

DaVanzo, J. (1981). "Repeat migration, information costs, and location-specific capital." Population \& Environment 4(1): 45-73.

Deaton, A. (1992). Understanding Consumption. Oxford University Press, Oxford.

Dercon, S. (1998) "Wealth, risk and activity choice: Cattle in western Tanzania." Journal of Development Economics 55:1-42

Dercon, S. (2005). Insurance Against Poverty. Oxford, Oxford University Press.

Dolfin, S. and G. Genicot (2006). "What do networks do? The role of networks on migation and 'coyote' use." Georgetown University Working Paper.

Dubois, J.-Y. and A. Araar (2006). Poverty and equity: Measurement, policy and estimation with DAD. Springer, New York.

Faist, T. (1997). The Crucial Meso-Level. International Migration, Immobility and Development. T. Hammer, G. Brochmann, K. Tamas and T. Faist. Oxford, Berg Publishers

Faist, T. (2000). The Volume and Dynamics of International Migration and Transnational Social Spaces. Oxford, Clarendon Press.

Fawcett, J. T. (1989). "Networks, Linkages, and Migration Systems." International Migration Review 23(3): 671-680.

Fischer, P. A., R. Martin, et al. (1997). Should I Stay or Should I Go? International Migration, Immobility and Development. T. Hammer, G. Brochmann, K. Tamas and T. Faist. Oxford, Berg Publishers

Foster, A. D. and M. R. Rosenzweig (2001). "Imperfect Commitment, Altruism, and the Family: Evidence from Transfer Behaviour in Low-Income Rural Areas." The Review of Economics and Statistics 83(3): 389-407.

Grogger, J. and G. H. Hanson (2008). "Income Maximization and the Selection and Sorting of International Migrants." NBER Working Paper 13821.

Gurak, D. T. and F. Caces (1992). "Migration Networks and the Shaping of Migration Systems." International Migration Systems: A Global Approach: 150-76.

Hagen-Zanker, J. (2008). "Why do people migrate? A review of the theoretical literature." MGSoG Working paper 2008/002.

Harris, J. and M. Todaro (1970). "Migration, Unemployment and Development: A

Two-Sector Analysis." The American Economic Review 60: 126-142.

Harvey, D. (1989). The Condition of Postmodernity. Oxford, Blackwell.

Hatton, T. J. and J. G. Williamson (2002). "What Fundamentals Drive World Migration?", NBER Working Paper 8124, National Bureau of Economic Research, Cambridge, MA." 
Haug, S. (2000). "Klassischere und neuere Theorien der Migration (Classical and newer theories of migration)." Arbeitspapiere- Mannheimer Zentrum fuer Europaeische Sozialforschung(30).

Heering, L., R. Van Der Erf, et al. (2004). "The Role of Family Networks and Migration Culture in the Continuation of Moroccan Emigration: A Gender Perspective." Journal of Ethnic and Migration Studies 30(2): 323-338.

Hicks, J. R. (1932). "Marginal Productivity and the Principle of Variation." Economica(35): 79-88.

Ibarraran, P. and D. Lubotsky (2007). Mexican immigration and self-selection: New evidence from the 2000 Mexican Census. Mexican Immigration to the United States. G. Borjas. Chicago, University of Chicago Press.

Khagram, S. and P. Levitt (2008). The Transnational Studies Reader: Intersections and Innovations, New York, Routledge.

King, R. (1995). "Migrations, globalisation and place." A Place in the World. D. Massey and P. Jess. Oxford, Oxford University Press.

Kochar, A. (2004). "Ill-health, savings and portfolio choices in developing economies." Journal of Development Economics 73:257-285.

Koser, K. (1997). "Social Networks and the Asylum Cycle: The Case of Iranians in the Netherlands." International Migration Review 31(3): 591-611.

Koser, K. (2007). International Migration: A Very Short Introduction. Oxford, Oxford University Press.

Koser, K. and C.Pinkerton (2002). The Social Networks of Asylum Seekers and the Dissemination of Information about Countries of Asylum, Great Britain, Home Office, Research, Development and Statistics Directorate.

Kothari, U. (2003). "Staying put and staying poor?" Journal of International Development 15(5): 645-657.

Lee, E. (1966). "A Theory of Migration." Demography 3(1): 47-57.

Ligon, E. (1998) "Risk sharing and information in village economics." Review of Economic Studies 65:847-864.

Martin, P. L. and J. E. Taylor (1996). "The anatomy of a migration hump." Development Strategy, Employment, and Migration: Insights from Models. Paris: Organization for Economic Cooperation and Development: 43-62.

Massey, D. (1988). "Economic Development and International Migration in Comparative Perspective." Population and Development Review 14(3): 383-413.

Massey, D. (1990). "Social Structure, Household Strategies, and the Cumulative Causation of Migration." Population Index 56(1): 3-26.

Massey, D. (1993). Power-geometry and a progressive sense of place. Mapping the Futures: Local Cultures and Global Change. J. Bird, B. Curtis, T. Putman, G. Robertson and L. Tickner. London, Routledge: 59-69. 
Massey, D., J. Arango, et al. (1993). "Theories of International Migration: A Review and Appraisal." Population and Development Review 19(3).

Massey, D., J. Arango, et al. (1998). Worlds in Motion. Oxford, Clarendon Press.

Mazzucato, V. 2008. “The double engagement: Transnationalism and integration Ghanaian migrants' lives between Ghana and the Netherlands." Journal of Ethnic and Migration Studies 34 (2): 199-216.

McKenzie, D. and H. Rapoport (2008). "Self-Selection patters in Mexico-U.S. migrations: The role of migration networks." World Bank Policy Research Working Paper 4118.

Miluka, J., C. Carletto, et al. (2007). "The Vanishing Farms: The Impact of International Migration on Albanian Family Farming " World Bank Policy Research Working Paper 4367.

Mincer, J. (1978). "Family Migration Decisions." Journal of Political Economy 86(5): 749-773.

Mishra, P. (2007). "Emigration and Wages in Source Countries: Evidence from Mexico." Journal of Development Economics 82(1): 180-99.

Moragas, J. F.-H. (2008). "New Evidence on Emigrant Selection." UFAE and IAE Working Papers 742.08.

Morris, S., C. Carletto, et al. (1999). "Validity of Rapid Estimates of Household Wealth and Income for Health Surveys in Rural Africa." Food and Consumption Division Discussion Paper No. 72.

Neubourg, C. d. (2002). The welfare pentagon and the social management of risks. Social security in the global village R. Sigg and C. Behrendt. New Brunswick, Transaction publishers. 8: 313-331.

Neubourg, C. d., P. Beckers, et al. (2008). Burning Bridges, Building Ships; Changes in Immigration in the Netherlands: Trends, Policies and Incentives, Maastricht Graduate School of Governance.

Neubourg, C. d. and C. Weigand (2000). "Social Policy as Social Risk Management." Innovation: The European Journal of Social Sciences 13(4): 401-12.

Orrenius, P. M. (1999). "The Role of Family Networks, Coyote Prices, and the Rural Economy in Migration from Western Mexico:1965-1994." Federal Reserve Bank of Dallas Working Paper 9910.

Ravenstein, E. G. (1885). "The Laws of Migration." Journal of the Statistical Society of London 48(2): 167-235.

Reilly, B., J. Litchfield, et al. (2005). "Who is most likely to migrate from Albania." Development Research Centre on Migration, Globalisation \& Poverty Briefing No. 2.

Ritchey, P. N. (1976). "Explanations of Migration." Annual Review of Sociology 2: 363-404.

Rosenzweig, M. (1988). "Risk, implicit contracts and the family in rural areas of low-income countries." The Economic Journal 98:1148-1170. 
Rosenzweig, M. and K. Wolpin (1993). “Credit market constraints, consumption smoothing, and the accumulation of durable production assets in lowincome countries: Investments in bullocks in India." The Journal of Political Economy 101:223-244.

Roy, A. D. (1951). "Some Thoughts on the Distribution of Earnings." Oxford Economic Papers 3: 135-46.

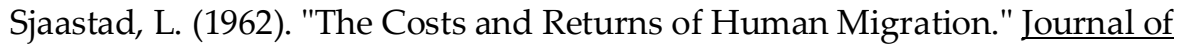
Political Economy 70(5): 80-93.

Stark, O. (1991). The Migration of Labour. Oxford, Blackwell Publishers.

Stark, O. and D. E. Bloom (1985). "The New Economics of Labour Migration." American Economic Review 75: 173-178.

Stark, O. and R. E. B. Lucas (1988). "Migration, Remittances, and the Family." Economic Development and Cultural Change 36(3): 465-481.

Stark, O. and E. Taylor (1991). "Migration Incentives, Migration Types: The Role of Relative Deprivation " The Economic Journal 101.

Udry, C. (1994) "Risk and insurance in a rural credit market: An empirical investigation in northern Nigeria." Review of Economic Studies 61: 494526.

Udry, C. (1995) “Risk and saving in northern Nigeria." The American Economic Review 85: 1287-1300.

United Nations Development Programme (2007). 2007 Human Development Report.

Vertovec, S. (2009) Transnationalism, New York, Routledge.

Wilpert, C. (1992). The use of social networks in Turkish migration to Germany. Immigrant associations in Europe. J. Rex, D. Joly and C. Wilpert. Gower, Aldeshot: 177-189. 


\section{Appendix 2.1}

\section{Descriptive summary statistic}

Moldova

\begin{tabular}{|l|r|r|r|r|r|}
\hline Variable & \multicolumn{1}{|l|}{ Obs } & \multicolumn{1}{l}{ Mean } & Std. Dev & Min & Max \\
\hline migrant & 11702 & 0,154076 & 0,361037 & 0 & 1 \\
\hline age & 11583 & 41 & 18 & 16 & 100 \\
\hline age squared & 11583 & 2024 & 1631 & 256 & 10000 \\
\hline male & 11671 & 0,464485 & 0,498758 & 0 & 1 \\
\hline married & 11663 & 0,638086 & 0,480575 & 0 & 1 \\
\hline Household head male & 11702 & 0.804 & .396 & 0 & 1 \\
\hline Household head age & 11702 & 51,74 & 13,65 & 16 & 100 \\
\hline Houehold head married & 11700 & 0,8 & 0,4 & 0 & 1 \\
\hline \# Children in household & 11702 & 0,588446 & 0,871446 & 0 & 8 \\
\hline primary & 11457 & .1367 & .343 & 0 & 1 \\
\hline secondary & 11457 & 0,354019 & 0,478236 & 0 & 1 \\
\hline vocational & 11457 & 0,301126 & 0,458767 & 0 & 1 \\
\hline university & 11457 & 0,208082 & 0,405954 & 0 & 1 \\
\hline Urban & 11702 & 0,361391 & 0,480424 & 0 & 1 \\
\hline HH size & 11702 & 3,785336 & 1,56512 & 1 & 13 \\
\hline asset index & 11702 & 0,676644 & 1,172616 & 0 & 13,26787 \\
\hline Asset index squared & 11702 & 1,832757 & 6,036085 & 0 & 176,0363 \\
\hline $\begin{array}{l}\text { Adults employed in the } \\
\text { hh ratio }\end{array}$ & 11702 & 0,196037 & 0,259339 & 0 & 1 \\
\hline $\begin{array}{l}\text { Household head } \\
\text { employed }\end{array}$ & 11665 & 0,206087 & 0,404511 & 0 & 0 \\
\hline $\begin{array}{l}\text { Community's migrant } \\
\text { share }\end{array}$ & 11702 & .0660 & .0483 & & 0 \\
\hline
\end{tabular}


Albania

\begin{tabular}{|c|c|c|c|c|c|}
\hline & Obs & Mean & St dev. & Min & Max \\
\hline Migrant & 11744 & 0.085 & 0.279 & 0 & 1 \\
\hline Age & 11744 & 41.009 & 18.289 & 15 & 105 \\
\hline Age2 & 11744 & 2016.185 & 1668.536 & 225 & 22025 \\
\hline Gender male & 11744 & 0.461 & 0.498 & 0 & 1 \\
\hline Married & 11744 & 0.648 & 0.477 & 0 & 1 \\
\hline HH lives in urban area & 11744 & 0.553 & 0.497 & 0 & 1 \\
\hline HHH age & 11744 & 52.520 & 12.504 & 16 & 96 \\
\hline HHH male & 11744 & 0.929 & 0.257 & 0 & 1 \\
\hline HHH married & 11744 & 0.906 & 0.291 & 0 & 1 \\
\hline \# Children in $\mathrm{HH}$ & 11744 & 1.100 & 1.178 & 0 & 7 \\
\hline HH size & 11740 & 4.828 & 1.858 & 1 & 16 \\
\hline Number of extended family members & 11744 & 8.782 & 3.588 & 0 & 22 \\
\hline Morris score index & 11744 & 0.381 & 0.301 & 0 & 1.342 \\
\hline Morris score index 2 & 11744 & 0.241 & 0.274 & 0 & 1.80 \\
\hline Primary education & 11744 & 0.508 & 0.491 & 0 & 1 \\
\hline secondary education & 11744 & 0.211 & 0.411 & 0 & 1 \\
\hline vocational education & 11744 & 0.154 & 0.361 & 0 & 1 \\
\hline higher education & 11147 & 0.091 & 0.288 & 0 & 1 \\
\hline HH work ratio & 11744 & 0.469 & 0.291 & 0 & 1 \\
\hline HHH employed & 11648 & 0.649 & 0.477 & 0 & 1 \\
\hline $\begin{array}{l}\text { Whether bank is a possible source of } \\
\text { credit in this community }\end{array}$ & 11121 & 0.632 & 0.482 & 0 & 1 \\
\hline Number of friends & 11744 & 1.901 & 1.777 & 0 & 40 \\
\hline Number of times joined other people & 11744 & 1.381 & 2.998 & 0 & 31 \\
\hline Community's migrant share & 11744 & 0.103 & 0.063 & 0 & 0.511 \\
\hline Participated in communal activities & 11744 & 0.104 & 0.306 & 0 & 1 \\
\hline $\begin{array}{l}\text { Can get credit from friends etc in } \\
\text { emergency }\end{array}$ & 11744 & 0.441 & 0.496 & 0 & 1 \\
\hline $\begin{array}{l}\text { Number of groups household belongs } \\
\text { to }\end{array}$ & 11744 & 0.24 & 0.696 & 0 & 6 \\
\hline $\begin{array}{l}\text { Number of community organisations in } \\
\text { community }\end{array}$ & 11154 & 5.398 & 3.433 & 0 & 13 \\
\hline Household receives public transfers & 11718 & 0.589 & 0.492 & 0 & 1 \\
\hline Community has public lighting & 11744 & 0.606 & 0.489 & 0 & 1 \\
\hline Community has phone & 11744 & 0.548 & 0.498 & 0 & 1 \\
\hline Community has mail & 11744 & 0.562 & 0.496 & 0 & 1 \\
\hline Community has police station & 11744 & 0.478 & 0.500 & 0 & 1 \\
\hline
\end{tabular}


Chapter 3: A critical discussion of the motivations to remit in Albania and Moldova

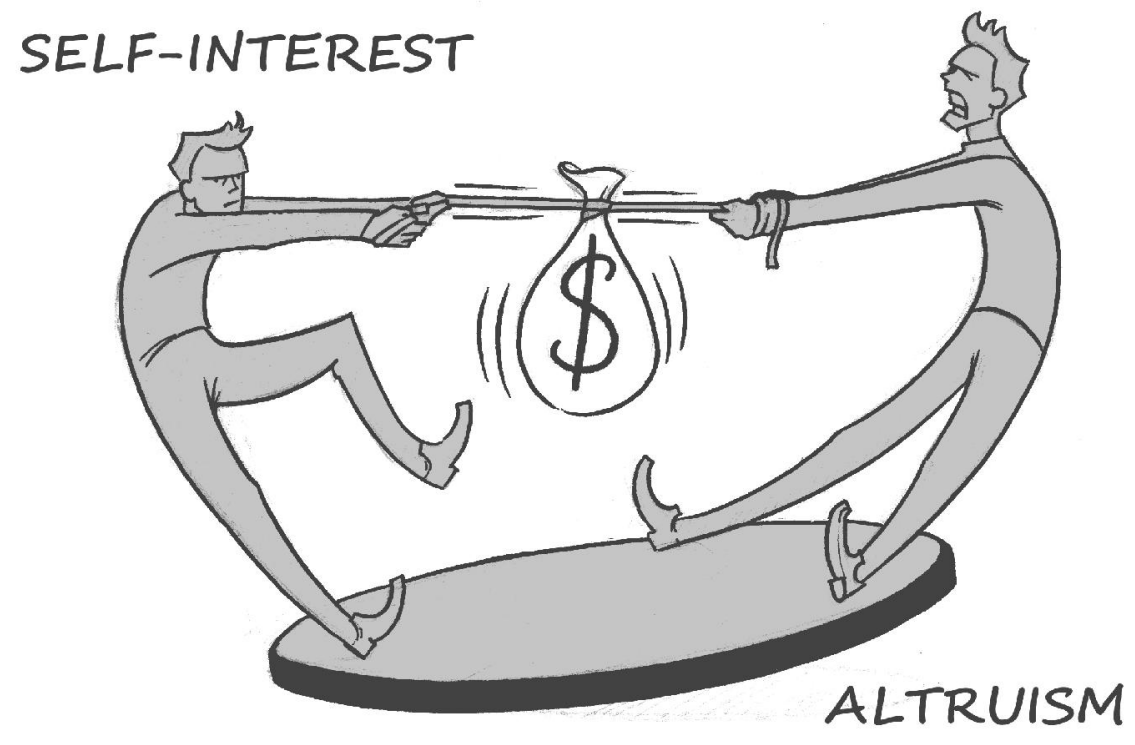




\subsection{Introduction 22}

Since the 1980s, the theoretical and empirical literature on the motivations to remit has grown steadily. In this chapter, we review the microeconomic literature and show that the theoretical motivations to remit are overlapping while competing. We argue that in most cases this differentiation is unnecessary and makes the subsequent empirical applications weak. We apply the theories in Albania and Moldova, two countries that experience high migration and remittance flows, using household survey data. We focus on finding evidence for the theoretical motivations to remit such as altruism, loan repayment, co-insurance and the bequest motive and use a similar methodology and approach as previous empirical research to show inconsistencies. As in other empirical papers, the analysis leads to doubtful and multi-interpretable results. We argue that this problem is caused by weak operationalisation and inseparability of motives, compounded by data problems. Furthermore we argue that the decision to remit should not be looked at in isolation. It is apparent that the causes and patterns of migration in Albania and Moldova influence the remitting behaviour and that many economic migrants migrate in order to remit. It is, thus, vital to link the decision to migrate with the decision to remit and to broaden the focus beyond the economic literature and consequently provide a more relevant and clearer answer to the question why remittances are sent.

Albania and Moldova have both experienced high migration outflows and remittance inflows in recent years. Both countries are major remittance recipients with remittances making up a significant fraction of GDP. Both countries share a communist past and their current economic situation is similar; they are two of the poorest countries in Europe, with weak social protection systems and weak financial sectors. They are also highly dependent on remittances for foreign exchange and poverty reduction. Remittances have financed the growing trade deficit in both Albania and Moldova. Therefore, it is relevant and interesting to study the motivations to remit in these countries.

Albania has experienced dramatic, sudden and intense migration outflows since the end of the communist era in 1991(King, 2005). Figure 3.1 shows the cumulative

\footnotetext{
22 This paper is based on the paper Hagen-Zanker, Jessica and Melissa Siegel (2009) "A critical discussion of the determinants of remittances in Albania and Moldova", the Romanian Journal of European Studies (RJES) No. 7-8/2009. Forthcoming

*Thank you to Jorgen Carling, Chris de Neubourg, Carlo Azzarri, Denis de Crombrugghe, Britta Augsburg, Pawel Kaczmarczyk, Julie Vullnetari, Erik de Regt, Catalina AmuedoDorantes and two anonymous referees for their helpful comments on an earlier draft of this paper. Thank you to INSTAT and the World Bank for the 2003 LSMS data for Albania and the IOM and Matthias Luecke for the CBS-AXA database on Moldova.
} 
stock of emigrants. According to the 2001 census, 710,000 people out of a population of 3.07 million have migrated, which constitutes $23 \%$ of the population (INSTAT, 2004). Including seasonal migration more than a million people are estimated to have migrated since 1990, mostly to Greece and Italy (Vullnetari, 2007). Political factors and the desire for personal liberation and self-expression are a motivation for emigration, but the desperate economic situation was an important factor from the beginning. Most of the early migrants were young and relatively well-educated, but from large and poor households (Konica, 2006). Seasonal and short term migration is especially common at the Albania-Greece border (Barjaba \& King, 2005). In recent years, migrants often stay abroad for longer periods of time and bring their families over (Zwager, Gedeshi, Germenji, \& Nikas, 2005), many becoming legalised.

Figure 3.1 gives an overview of remittances as a percentage of Albanian GDP. Remittances have grown from \$150 million in 1992 to \$1 billion in 2004. In 2004 remittances made up 13.7\% of GDP (Zwager, Gedeshi, Germenji, \& Nikas, 2005), five times more than foreign direct investment and three times more than official development aid. In 2005, approximately one in five households received remittances and $68.6 \%$ of the migrants sent remittances home to their families (Zwager, Gedeshi, Germenji, \& Nikas, 2005).

\section{Figure 3.1 Albania emigration and remittances}

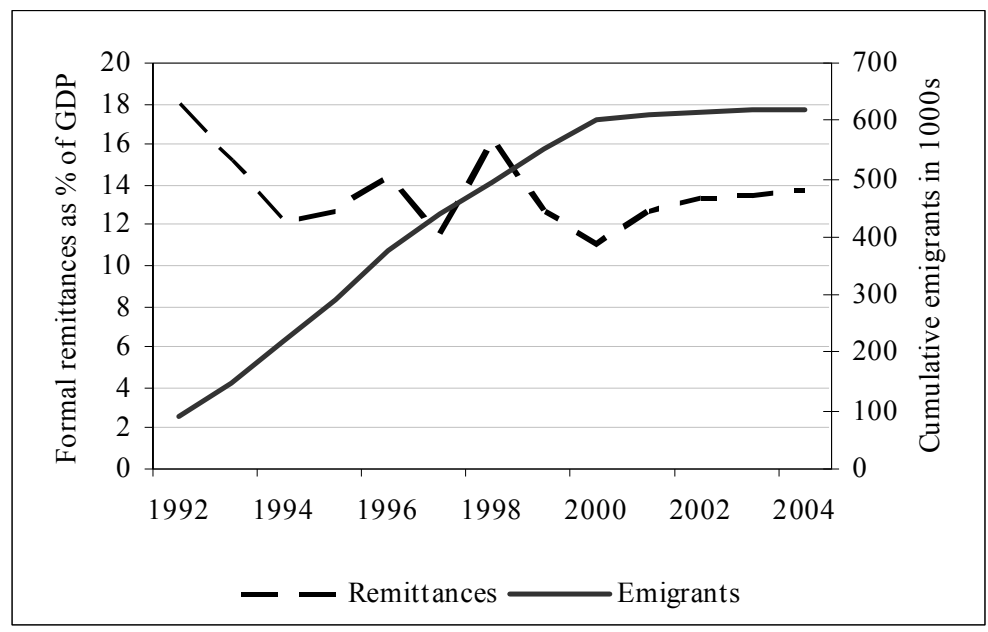

Source: IMF (2006)

Moldova also entered transition from central planning to free markets at the beginning of the 1990s. Because of Moldova's dependence on Russia, the breakdown of the Russian economy in the early 1990s threw Moldova into an extreme collapse that was worse than in other Soviet Republics. Therefore, 
migration in Moldova was mainly driven by poverty. In such serious economic conditions, much of the population tried to find employment abroad to mitigate the difficult situation at home. Figure 3.2 shows the migration trends of labour migrants from Moldova between 1999 and 2003. There were almost 400,000 Moldavians living abroad by 2004. Remittances began to increase noticeably in 1998 during the regional crisis, which encouraged continued large-scale migration. The recovery of the economy after 1999 was primarily driven by remittances (Cornea et al., 2005). By 2005, emigrants accounted for about $28 \%$ of the working population and about $18 \%$ of the population of Moldova (Government of the Republic of Moldova, 2006).

Moldovan migrants keep a strong attachment to their home and remit large portions of their income. However, while in Albania family reunification in the host country is quite frequent, Moldova experiences more temporary migration of both men and women. The bulk of remitters are short-term migrants, many of whom are seasonal (working in agriculture or construction in Russia). In contrast to Albania, $70 \%$ of all remittances received are from temporary workers who stay abroad only part of the year (IMF, 2006). By 2004, formal remittances had grown to $\$ 700$ million, constituting the equivalent of $27 \%$ of GDP (CBS-AXA, 2005), which is almost eight times more than foreign direct investment and seven times more than official development aid.

\section{Figure 3.2 Moldova emigration and remittances}

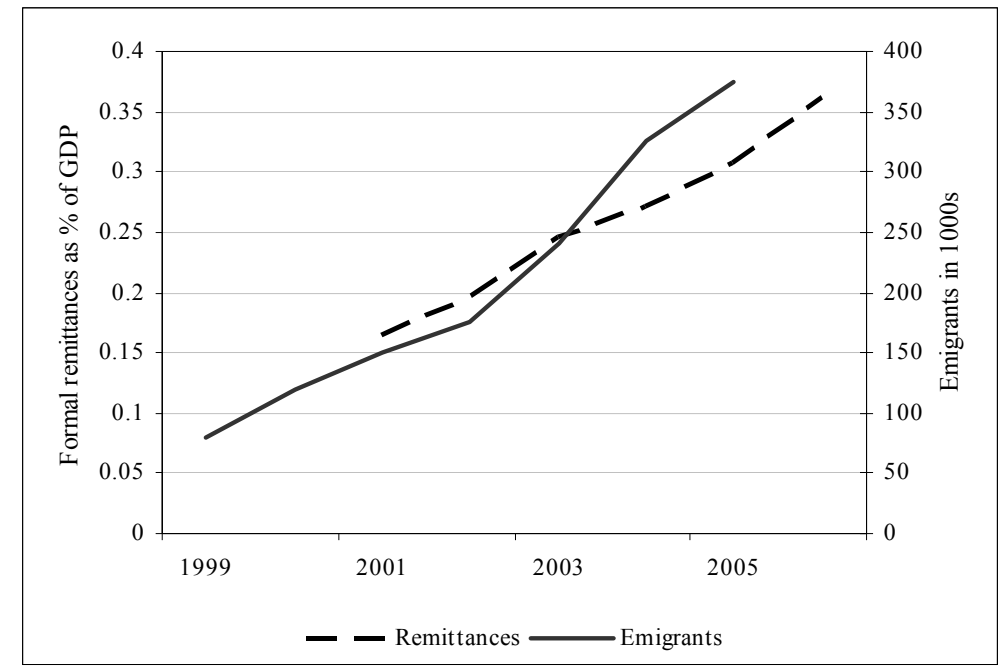

Source: Worldbank (2007) and Moldova Department of Statistics and Sociology in Cuc et al (2005) 
As was shown above, remittances play an important role for both Albania and Moldova, both at the macroeconomic and microeconomic level. In this chapter we investigate the motivations to remit and characteristics of remittance-receiving households. These driving forces are of major interest to policy makers wishing to attract more remittances as well as to researchers focusing on the determinants of private transfers.

This chapter builds on the growing theoretical and empirical literature on the motivations to remit that explains the sending of remittances between household members with motives such as altruism, co-insurance, loan repayment and the bequest motive. We critically review the literature, point out the main problems and illustrate them with an empirical application for Albania and Moldova that goes beyond previous studies on Albania and Moldova (see Germenji, Beka, \& Sarris (2001) for Albania and for Moldova (Craciun, 2006; Görlich, Mahmoud, \& Trebesch, 2007; Görlich \& Trebesch, 2008). We use household survey data from Albania and Moldova for the years 2003/ 2004. Finally, we discuss which elements are missing in the current literature and suggest a way forward.

Section two critically discusses the theoretical literature on the determinants of remittances. Section three covers the methodology and data used. Section four reports, analyses and discusses the results in light of the other empirical literature on the motivations to remit and section five concludes.

\subsection{Literature review of motivations to remit}

In this section we briefly review and critically discuss the current state of theoretical literature on the motivations to remit. While the decision to remit is clearly linked to the causes of migration, the majority of the economic literature on the motivations to remit focuses exclusively on remitting. The empirical literature will be discussed in section 4 together with our empirical application. ${ }^{23}$

The theoretical debate on the motivations to remit was triggered by Lucas and Stark (1985) with their ground-breaking paper "Motivations to remit: Evidence from Botswana". They investigate remittances on a household level and argue that remitting migrants are influenced by different motivations, namely "pure altruism", "pure self-interest" and "tempered altruism or enlightened selfinterest". Any kind of contractual arrangements between the migrant and the household left behind can be in the latter category; for example, co-insurance, exchange motives and loan repayment. The theoretical motives and their effects on the level of remittances are summarised in table 3.1.

\footnotetext{
${ }^{23}$ See Hagen-Zanker \& Siegel (2007) for a more extensive review of the empirical literature.
} 
Table 3.1 Theoretical motivations to remit

\begin{tabular}{|c|c|c|c|c|c|}
\hline $\begin{array}{c}\text { Effect of ... on level of } \\
\text { remittances }\end{array}$ & \begin{tabular}{|c|} 
Pure \\
altruism
\end{tabular} & $\begin{array}{c}\text { Pure self- } \\
\text { interest }\end{array}$ & $\begin{array}{c}\text { Co- } \\
\text { insurance }\end{array}$ & $\begin{array}{c}\text { Loan } \\
\text { repayment }\end{array}$ & $\begin{array}{c}\text { Exchange } \\
\text { motives }\end{array}$ \\
\hline $\begin{array}{l}\text { household income } \\
\text { (home country) }\end{array}$ & - & + & - & $+/-$ & $+/-$ \\
\hline $\begin{array}{l}\text { migrant income } \\
\text { (host country) }\end{array}$ & + & + & - & + & + \\
\hline $\begin{array}{l}\text { shock occurring to } \\
\text { household (home } \\
\text { country) }\end{array}$ & + & & + & & \\
\hline risk level of migrant & & & + & & \\
\hline $\begin{array}{l}\text { education level of } \\
\text { migrant }\end{array}$ & & & & + & + \\
\hline intent to return & & + & & & \\
\hline no. of migrants in $\mathrm{HH}$ & - & & & & \\
\hline time & - & & & + , later - & \\
\hline
\end{tabular}

A basic motivation of a remitting migrant may be altruistic feelings towards the family left behind. In the literature, this is modelled so that the migrant derives positive utility from the consumption of the family. The migrant, thus, cares about poverty, shocks, etc. of the family and consequently sends remittances to alleviate negative pressures. In this case, there is a positive relationship between adverse conditions of the receiving household and remittances sent. Remittances should increase with migrant income (the migrant has more to share) and strength of altruism and decrease or stay the same with recipient income (Funkhouser, 1995). ${ }^{24}$ This result has to do with there being less need to send remittances so fewer remittances will be sent. With regard to the altruism motive, it is also hypothesized that remittances will decrease from a sender when there are more migrants (remittance senders) in the receiving household. With more people sending, there is the possibility for the same needs to be met with less sending from each person. Time is another factor discussed in the literature on remittance behaviour. Time is usually seen to be negatively correlated with remittances from an altruism standpoint. The idea is that as time passes, the ties between the remitter and the receiver grow apart and then there is less utility gained from sending money. There is a wide academic discussion on how to measure altruism, but most authors

${ }^{24}$ However, income does not necessarily have a linear effect. As Cox, Jimenez, \& Okrasa (1997) demonstrate, income may have a different effect at different points of the receiving household income distribution. 
agree that measuring altruism by only looking at the effect of giver and receiver income is controversial. It is very abstract and perhaps too rational an operationalisation of decision making and, additionally, captures other effects.

The second remitting motive discussed in the literature is self-interest. In this case, a migrant sends remittances with the aspiration to inherit, to demonstrate laudable behaviour as an investment for the future or with the intent to return home. If a migrant wants to invest at home, the household can be a trustworthy and wellinformed agent. If a migrant intends to return home, he may already invest in housing, livestock etc. and will ask the family to be the agent. The migrant may also send remittances to invest in his reputation at home. Furthermore, a migrant may remit in order to be ranked highly in the (implicit) will of his family. With a bequest motive, remittances increase with the household's assets and income, the probability of inheriting (dependent on the age of parents, number of siblings, etc.), the migrant's wealth and income, and decreases with risk aversion. In the case of a bequest motive, self-interest can be distinguished from altruism using conventional explanatory variables, where larger income and/or wealth of the household in the home country should lead to more remittances.

The first contractual arrangement that may be the result of tempered altruism is coinsurance between households and migrants, as highlighted in the New Economics of Labour Migration (NELM). According to the NELM, a household member migrates to a non-correlated labour market due to market failures in the source country (for example poorly developed financial markets), entering a type of coinsurance agreement with the household left behind. These contracts are selfenforcing when mutual altruism is present or in patriarchal societies (Sana \& Massey, 2005). Remittances are sent home when the household in the home country experiences shocks and to enable the household to invest in new technology. At the same time, the household also supports the migrant, e.g. by paying for the migrant's living expenses during spells of unemployment. Remittances consequently increase when the household experiences a (income) shock (like for altruism), but also when the risk-level of the migrant increases. When income is decreased in either the home or host country, the other will compensate. Table 3.1 refers to remittances going both directions for this motive. The NELM is the only economic theory that explicitly links the motive to remit to the decision to migrate. This is crucial since the intent to send remittances is likely to be a major consideration in the decision to migrate. ${ }^{25}$

\footnotetext{
${ }^{25}$ The omission of this link is not only a theoretical gap but is likely to also affect the empirical results because there are two sample biases amongst the group of remitters: The selectivity of migrants among the general population (ignored and not taken account of in the literature) and the selectivity of remitters amongst migrants (generally corrected in the literature).
} 
Another type of contractual agreement between the household and family is loan repayment, for example, repaying of human capital investment or the cost of migration. According to this theory, a household finances a potential migrant's education which enables him to find a better-paid job in the city or abroad (Poirine, 1997). During the next time period the migrant will send remittances to repay the family for the initial investment ("payback-phase"). At this stage the migrant might also become a lender, by financing other family member's education, which increases overall remittances ("loan phase"). In practice, only paying-back can be measured and there should be a positive link between the migrant's education level and remittances. However, this could also be interpreted as altruism or another motive due to the close link between education and income. The household back home also often finances the initial migration, so remittances are sent back to replay this loan.

A final contractual arrangement is the exchange motive (Cox, 1987). Here, transfers in the wider sense are paid to the household at home for services provided. The theory can also be applied to remittances, whereby remittances buy various types of services (e.g. child care), usually by temporary migrants (Rapoport \& Docquier, 2005). If the migrant's income increases, remittances increase. If the household's income increases, thus making the services more expensive, remittances can decrease or increase depending on the migrant's elasticity of demand. Higher unemployment in the home country should lead to fewer remittances since less money is then needed to make the household members perform their service (the opposite effect is found for altruism).

While the above motives are considered to be separate and different, they overlap (for example in the reaction to shocks) and are essentially all the same motive, namely an increase in welfare for the remitter. All motives can be included in a general individual welfare maximisation function where the individual maximises welfare that includes different elements including own income and household welfare (altruistic motive), possibly over several time periods (loan repayment, insurance or bequest motive). The fact that these motives overlap and are already difficult to measure separately in theory, makes it even more difficult to test the motives empirically, as our empirical application will show.

While the economic literature focuses on strategic motivations that were freely chosen, more social motivations, like prestige and responsibility are not considered. Furthermore, the economic literature neglects the fact that migrants may be willing, but not able to send remittances due to unexpected averse conditions in the host country ${ }^{26}$. Moreover, family dynamics and the question of

\footnotetext{
${ }^{26}$ Al-Ali, Black, \& Koser (2001) differentiate between the capacity and the desire of refugees to send remittances. This is an important nuance that should also be considered for economic migrants.
} 
which family member in particular migrates, has not been discussed much in the economic literature even though they are likely to influence remitting behaviour. When a migrant goes abroad or forms a new family abroad, the structure of the family left behind changes. Who migrates abroad affects the motives for remitting and, thereby, the amount remitted. For example, a husband might be altruistic and send as much as possible to his wife and children back home, while a son might feel it is a duty to remit occasional amounts ${ }^{27}$.

As was shown above, the theoretical literature is not able to clearly separate the different motives of remitting. This is a major obstacle from the start in the empirical applications and affects the strength of the conclusions that can be drawn ${ }^{28}$, but it has inspired some authors (e.g. Amuedo-Dorantes \& Pozo (2006)) to measure the motives more creatively. In section 4 we measure the motivations to remit in Albania and Moldova in different ways and compare and contrast our results with other empirical applications to demonstrate the difficulty of measuring the motivations to remit, when the different theories overlap and compete.

\subsection{Methodology and data}

\subsubsection{Methodology}

Early papers on the motivations to remit used Ordinary Least Squares (OLS) (for example Lucas \& Stark (1985)) to model the remittance decision. We now know that using such a method leads to biased and inconsistent estimates, since a substantial fraction of the migrants does not remit. In recent papers, the main methodological distinction is made between modelling the motivations to remit as a one-stage decision (Tobit) where the decision to remit and the amount of remittances are made together or as a Heckmann two-stage approach (Probit and corrected OLS) where the model separates the decision to remit and the subsequent decision of how much to remit. The advantage of the latter approach is that it allows a regressor to differently affect the decision to remit and the level of remittances. Amuedo-Dorantes \& Pozo (2006), on the other hand, argue that using a two-part selection model leads to identification problems, i.e. it is hard to say which variables would matter for one decision and not the other.

\footnotetext{
${ }^{27}$ A very interesting empirical application is Sana \& Massey (2005) who show that sons and daughters from the Dominican Republic have very different remitting behaviour and clearly make the link between changes in family dynamics and remittances.

${ }^{28}$ Liu \& Reilly (2004) is one of the few papers that explicitly discusses the difficulty of drawing clear conclusions on remittance motives from multi-interpretable results.
} 
An alternative to the two-stage approach is to assume that there is only one remittances decision in which the two stages occur simultaneously. This one-stage decision can be modelled as a single equation estimated by Tobit analysis, using both remitting and non-remitting migrants. Each regressor has the same effect on the probability of being a remitter and on the level of remittances. The convenience of this approach is that it enables the identification of a set of variables that are most significant in influencing "remittance behaviour". It can be argued that a Tobit model is over-restrictive in forcing the regressors to have the same effect on both the decision to remit and how much to remit. Hoddinott (1992) has noted, however, that in none of the theoretical literature on migration and remittances has a distinction been made between factors influencing the decision whether to remit and the level of remittances. We, therefore, assume that the remittance decision is a one-stage process and will model it using a Tobit model.

The Tobit model is specified as in equation 1 below:

$$
R_{i}^{*}=\beta^{\prime} X_{i}+u_{i} \quad u_{i} \sim N\left(0, \sigma^{2}\right)
$$

where

$$
R_{i}=\left\{\begin{array}{c}
R_{i}^{*} i f R_{i}^{*}>0 \\
0 i f R_{i}^{*} \leq 0
\end{array}\right.
$$

$X_{\mathrm{i}}$ is a vector of explanatory variables

$\mathrm{R}_{\mathrm{i}}$ is the actual observed value of remittances

$\mathrm{R}^{*} \mathrm{i}$ is the latent dependent variable

The Tobit model is used for censored data, where the dependant variable $R^{*_{i}}$ is latent. In the following analysis, $R^{*}$ is observed for values that are higher than zero and it captures the i-th individual's propensity to remit. It has a normal, homoskedastic distribution with a linear conditional mean. $R_{i}$ is the actual observed value of remittances remitted by individual i. It can be either positive or zero and it is positive for those migrants that do remit.

A disadvantage associated with the Tobit approach is that the assumption of normally and homoskedastic distributed errors might not hold. If households have more than one remitter, remittances of both remitters partially depend on the same unobservable household characteristics and this results in error terms that are correlated across observations. ${ }^{29}$ Since most households in our datasets only have

\footnotetext{
${ }^{29}$ For a further discussion of this problem see (Gubert, 2002).
} 
one remitter we assume that this problem is minimal. We do the analysis at the individual level but also include characteristics of the receiving household.

\subsubsection{Data}

We use data from household surveys in the migrant sending country as the basis of our empirical analysis. For Albania, we use the Living Standards Measurement Survey (LSMS) collected by Albania's statistical agency INSTAT in 2005, with technical assistance of the World-Bank, which is representative on a national level and has a sample of 3640 households. This is a standard household survey and includes extensive modules on education, migration, consumption, labour etc. We compliment the household level data with information from a detailed community questionnaire in the communities of the households, which was collected at the same time.

For Moldova we use the CBSAXA 2006 Survey. The opinion research company CBSAXA conducted this migration household survey for the International Organization for Migration in Moldova. One important purpose of the CBSAXA survey is to compare households with migrants to those without. Therefore, the survey was designed to be representative of Moldovan households at the national level (excluding Transnistria), for each major geographic region (North; Center; South; Chisinau), and for each major type of locality (large cities: Chisinau and Balti; other towns; villages). The total number of households interviewed was close to 4,000 , resulting in a sampling error of approximately 3 percentage points for the share of households with migrants.

\subsubsection{Descriptive statistics}

We now discuss some descriptive statistics to gain a broad overview of the characteristics of senders and receivers in our Albanian and Moldovan samples. We first look at the characteristics of the households that receive remittances and then at the characteristics of the migrants that send remittances. We only look at households that have migrants since this is the basis of our empirical analysis.

Figure 3.3 shows the amount of remittances received. The first quartile represents the poorest quarter of the sample population and the last quartile represents the richest quarter of the sample population. In this table we see the average amount of remittances by expenditure quartile. A clear picture emerges for Albania; richer households receive higher remittances. In Moldova, the poorest households receive the most remittance. Those in the second quartile receive the least and then the $3^{\text {rd }}$ and $4^{\text {th }}$ quartiles receive close to the same amount. 


\section{Figure 3.3 Amount of remittances by expenditure quartiles}

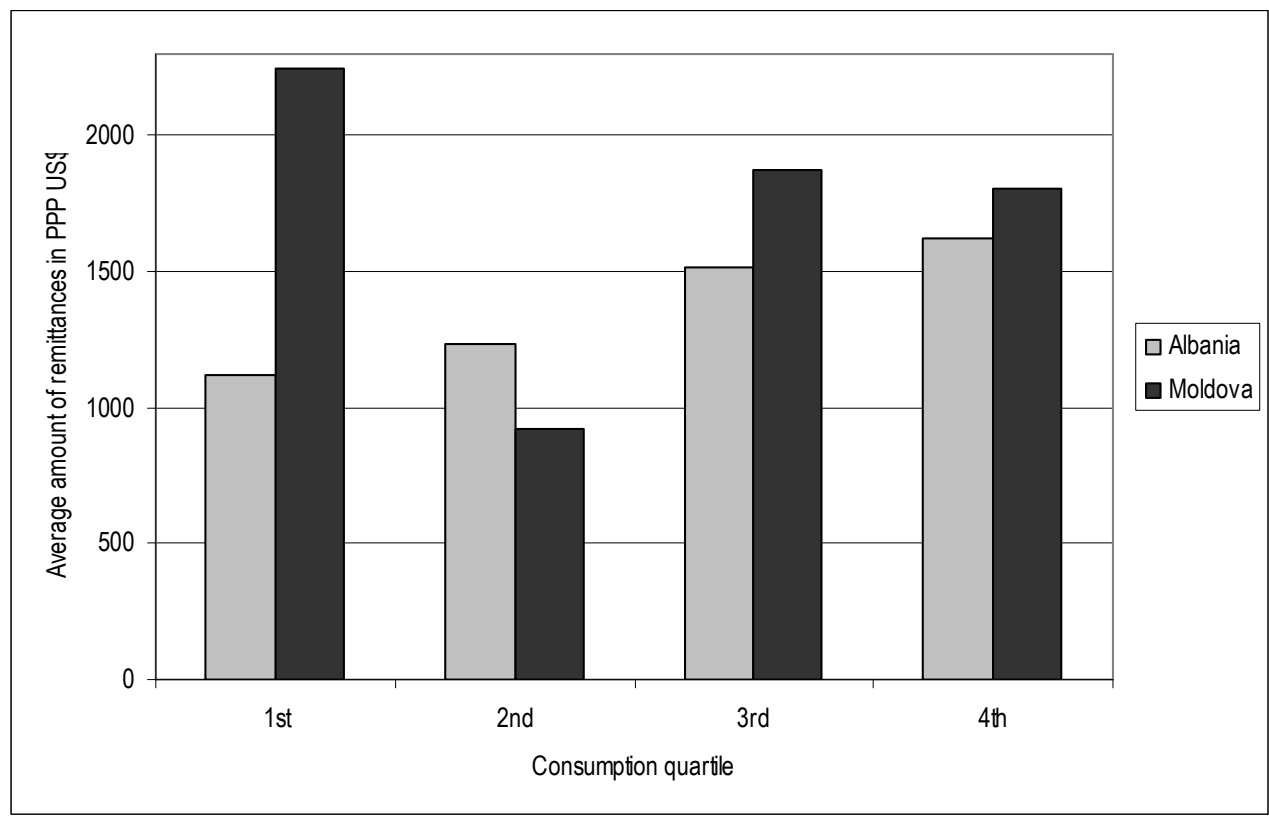

Source: Own calculations using ALSMS 2005 and CBS-AXA 2006

In both Albania (73\%) and Moldova (60\%), male migrants make up the majority of the remitting population (largely due to the fact that it is mostly males who migrate). In Albania, men also send higher amounts of remittances on average (\$1059, which is more than three times what women (\$239) remit on average), while in Moldova, women send higher amounts of remittances on average $\$ 475$, while men send \$434). In Albania traditional gender roles mean that it is the duty of the sons to look after their parents, much more so than for their sisters, especially if the sisters are married (King, Dalipaj, \& Mai, 2006). Over 60\% (Albania $87 \%$, Moldova 62\%) of the remitters in both Albania and Moldova are of working age between the ages of 25 and 45 and the majority of remitters in both countries are married and predominantly migrate to two countries: Italy and Greece for Albania $^{30}$ and Russia and Italy for Moldova. Moldovan migrants generally travel much larger distances for migration that Albania migrants.

Figure 3.4 shows the average number or years the remitter has been abroad. For both groups, short-term (usually seasonal migrants) remit less that migrant who have been abroad for longer. This trend is strong in Albania and increases with

${ }^{30}$ In our dataset $45 \%$ of the remitters were in Greece, which is understated compared to the Albanian migrant population as a whole. 
years abroad where as in Moldovan remittances start to decrease after 5 years but still remain relatively high.

\section{Figure 3.4 Number of years remitter has been abroad}

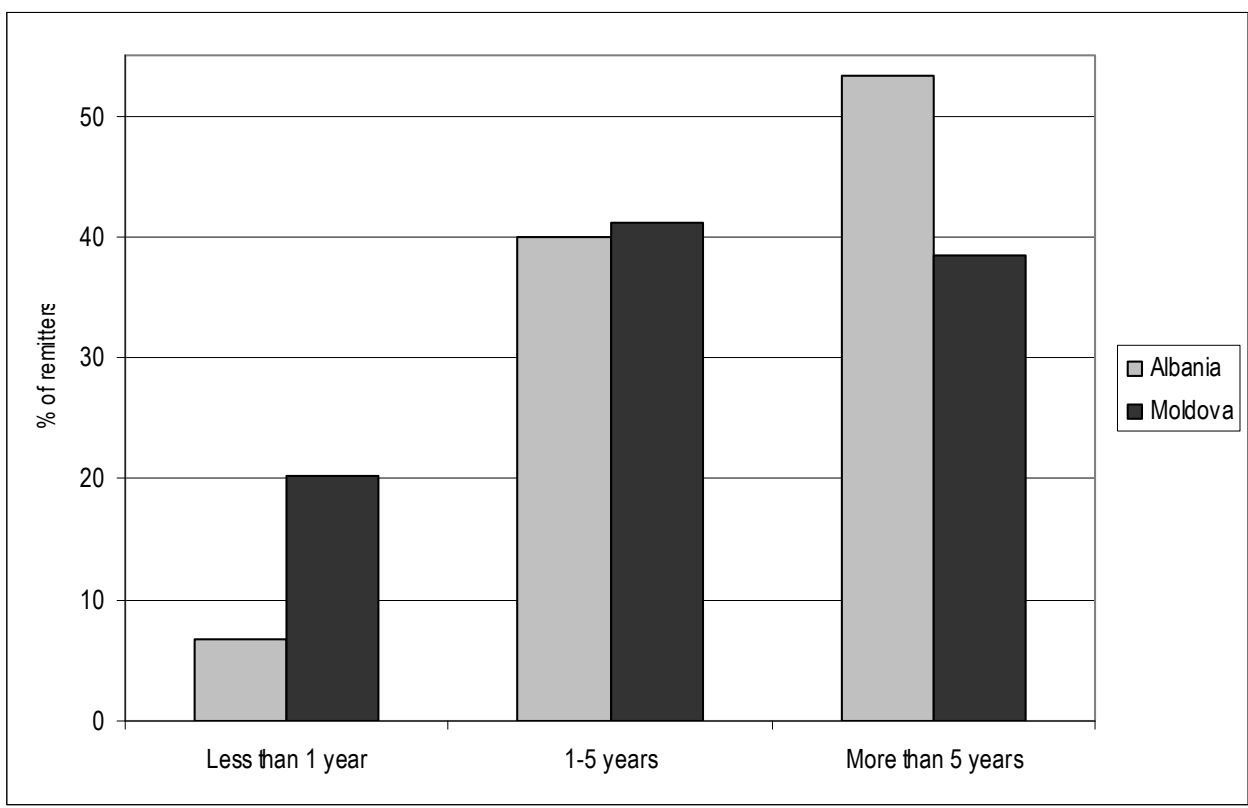

Source: Own calculations using ALSMS 2005 and CBS-AXA 2006

We continue to assess the individual characteristics of remitters by looking at the link between education of the remitter, the number of years abroad and their most important destination countries and the average amount of remittances sent home by remitters of each group. In Albania the distinction between level of education and remittances sent is less clear that for Moldova. In Albania, primary and secondary educated migrants send about the same amount (\$780). Migrants with vocational education send the most (\$815) and those with the highest education send the least (\$631). In Moldova the amount of money sent increases with education. 
Table 3.2 Average amount remitted during the past year by remitter characteristics in PPP US\$

\begin{tabular}{ll|c|c}
\hline & & Albania & Moldova \\
\hline \multirow{3}{*}{ Gender } & Female & $239.22^{* * *}$ & 475.24 \\
& Male & $1058.85^{* * *}$ & 434.27 \\
& Total & 772.35 & 450.5 \\
\hline \multirow{3}{*}{ Education } & Primary or less & 780.34 & $255.20^{*}$ \\
level & Secondary & 780.45 & 436.79 \\
& Vocational & 815.17 & 457.95 \\
& Higher & 631.36 & $559.90^{*}$ \\
& Total & 772.35 & 454.71 \\
\hline \multirow{4}{*}{ Years } & Less than 1 year & $426.23^{* * *}$ & 371.8 \\
& 1-5 years & 832.56 & 477.09 \\
& More than 5 years & 785.41 & 456.45 \\
\multirow{3}{*}{ Destination } & Total & 772.35 & 447.78 \\
\hline & Other & $918.19^{* *}$ & $651.85^{* * *}$ \\
& Greece/Russia & $611.18^{* * *}$ & $335.62^{* * *}$ \\
& Italy & $859.07^{* *}$ & $732.71^{* * *}$ \\
\hline Number of observations & 772.35 & 468.35 \\
\hline
\end{tabular}

Source: Own calculations using ALSMS 2005 and CBS-AXA 2006

As shown in Table 3.2, it is clear that those Moldovan and Albanian migrants who are away for short periods of time remit less than those away for longer periods. Both countries have two major destination countries for migration in which approximately 80 percent of the migrating population goes. Migrants from both countries that migrate to Italy remit more on average, than those going to the other important destination country, although this is much more pronounced in the case of Moldova. The Albanian remitters in Italy and Greece probably remit less than their Moldovan counterparts due to the nature of the remitters in our dataset.

The next section applies the theoretical motivations to remit in Albania and Moldova in order to give a more detailed picture of the motivations to remit in those countries and to demonstrate the problems associated with the literature. 


\subsection{Empirical motivations to remit in Albania and Moldova}

As was shown in section 2, even theoretically it is difficult to distinguish between different motivations to remit. These complications are exacerbated by data limitations (only having data on either the remitter or remittance receiver) and consequently the empirical applications are often weak. Below, we attempt to measure the motivations to remit in Albania and Moldova and discuss the results in relation to other empirical papers. Our starting point is a common model that has the same variables for both the Albanian and Moldovan datasets. For this model we measure the motivations to remit with regard to altruism versus insurance of the migrant. Due to the different nature of the two datasets, we specify two further models for just one of the countries. For Albania we use the data on a household and community level to model the bequest motive, coinsurance and to search for evidence for the NELM theory. As shown previously, the main group of remitters in Albania is the children group, so testing for the bequest motive is highly relevant. Our final model tests the loan repayment motive using only Moldovan data since we have relevant variables in that dataset.

\subsubsection{Measuring altruism and self-insurance (of the migrant) motives in Albania and Moldova}

In each of the following models, we have split the independent variables into migrant characteristics, household characteristics and specific variables that are used to test a number of theoretical motivations to remit. We describe the expected effects of the variables based on the theoretical motivations to remit, previous papers and the specific situations in Albania and Moldova.

In the first model, we test for altruism and insurance of the migrant. The model is outlined in equation 2 below:

$$
R_{i}^{*}=\alpha+\beta_{1} M_{i}+\beta_{2} H_{i}+\beta_{3} R i_{i}+\varepsilon_{i}
$$

\section{Where}


Table 3.3 Variables and expected effects for combined model

\begin{tabular}{|l|l|}
\hline Variable & $\begin{array}{l}\text { Expected } \\
\text { effect }\end{array}$ \\
\hline $\begin{array}{l}\text { R=amount of remittances received by the household } \\
\text { per sender over the last } 12 \text { months }\end{array}$ & n.a. \\
\hline M (Migrant variables) & control \\
\hline Age of migrant at departure & control \\
\hline Gender of migrant & control \\
\hline Marital status of the migrant & control \\
\hline Education of migrant & control \\
\hline Country of migrant destination & \\
\hline H (Household variables) & + \\
\hline Household size & - \\
\hline $\begin{array}{l}\text { Per capita income/expenditures of household in } \\
\text { quintiles }\end{array}$ & - \\
\hline Other migrants in household & control \\
\hline Household lives in urban/ rural area & \\
\hline Ri (Risk variables) & + \\
\hline Unemployment rate of country of destination & - \\
\hline Duration of migration, in categories & + \\
\hline $\begin{array}{l}\text { Distance between Albania/ Moldova and capital of } \\
\text { destination }\end{array}$ & - \\
\hline Migrant stock in destination country & - \\
\hline Legal entrance in country of destination & \\
\hline
\end{tabular}

To test the altruism motive, we look at the following variables: per capital household expenditures, number of other migrants in the household and the duration of migration. ${ }^{31}$ The coefficient for household income should have a negative sign for altruism, indicating more remittances for households with greater need. We use expenditure splines with two equally-spaced cut-off levels to allow remittances to have a different effect for poorer or richer households. The coefficient for number of migrants in the household should have a negative sign since more migrants means, more people to remit, which lowers the burden on the individual remitter. If family ties have weakened, often approximated by length of time abroad, fewer remittances should be sent ("remittance-decay"). A larger

${ }^{31}$ Due to data limitations, we had to omit migrant's earnings, which would be an important variable to include. We have checked the household variables for inter-correlation and found no problematic correlation between any of the variables. 
household at home can be an indication of need; we thus, expect a positive relationship with remittances in the case of altruism. ${ }^{32}$

Instead of focusing on household risks that make it difficult to differentiate between altruism and self-insurance, we focus on migrant employment risks. Therefore we test whether the migrant insures himself by looking at the effect of employment risk variables on the amount of remittances sent..$^{33}$ The basic idea is that the migrant sends more remittances (i.e. a higher "insurance premium") when the labour market situation is more risky to ensure reverse remittances in times of need or the support of the family if the migrant has to return home due to lack of work. The indirect measures of risk we use are the unemployment rate in the host country (due to non-availability of data on migrant unemployment), the duration of migration, the distance between the migrant sending, host country and stock of Albanian/ Moldovan migrants in the host country as a measurement of networks and legal entrance in the country of destination.

If the unemployment rate in the host country is higher, then it is expected that there is a higher labour market risk..$^{34}$ The shorter the duration of migration, the more money should be sent, as the migrant is less acquainted with the labour market and probably has not found stable employment yet. The greater the distance between the countries the higher the risk for the migrant, for example, financially, as the migration costs are higher, and the more money should be sent. A greater migrant stock should mean less risk, as networks are used by migrants to find jobs, housing, etc. If the migrant has entered the country legal, we consider them in a less risky situation, meaning that they will send less remittances than if they had entered illegally. Since we cannot control for migrant income, we measure the migrant's desire to take up insurance, but not his capacity.

\footnotetext{
${ }^{32}$ A higher number of household members can be an opportunity for the household if they are adults potentially earning an income or a risk if the members are children or elderly. Therefore, we tried different specifications also using the children or elderly ratio instead of household size, but generally household size gave us the best fit.

33 For a similar analysis see also Amuedo-Dorantes \& Pozo (2006) and Lianos \& Cavoundis (2004)

${ }^{34}$ The most popular migration destination countries of Albanian and Moldovan migrants do not include illegal migrants in unemployment insurance schemes.
} 
Table 3.4 Results of Tobit regression for combined model

\begin{tabular}{|c|c|c|c|c|}
\hline & \multicolumn{2}{|c|}{ Albania } & \multicolumn{2}{|c|}{ Moldova } \\
\hline & $\begin{array}{l}\text { Marginal } \\
\text { effects coeff. }\end{array}$ & st. error & $\begin{array}{l}\text { Marginal } \\
\text { effects coeff. }\end{array}$ & st. error \\
\hline Migrant variables & Jointly sign ${ }^{* * *}$ & & Jointly sign ${ }^{* *}$ & \\
\hline Age of migrant & 2.67 & 2.72 & $10.39^{* * *}$ & 2.69 \\
\hline Gender of migrant & $439.88^{* * *}$ & 45.09 & 35.44 & 57.89 \\
\hline Marital status of the migrant & $-166.87^{* * *}$ & 48.19 & -36.38 & 62.48 \\
\hline Migrant secondary education & $78.27^{*}$ & 43.74 & 194.77 & 125.64 \\
\hline Migrant vocational education & $129.02^{* *}$ & 58.44 & 176.28 & 126.42 \\
\hline Migrant higher education & -6.63 & 77.10 & $229.83^{*}$ & 133.82 \\
\hline Migrant in Italy (A)/ CIS (M) & -317.61 & 503.37 & 535.31 & 761.20 \\
\hline Migrant in Greece (A)/ EU (M) & -257.00 & 733.68 & -2.79 & 141.78 \\
\hline HH variables & Jointly sign ${ }^{* * *}$ & & Jointly sign ${ }^{* *}$ & \\
\hline HH size & $28.74^{* *}$ & 11.40 & 0.26 & 21.52 \\
\hline Income/Expenditure quartile 1 & $-89.66^{* *}$ & 21.04 & $-122.90^{* *}$ & 57.87 \\
\hline Income/Expenditure quartile 2 & $-86.38^{* * *}$ & 19.23 & $-31.34^{* * *}$ & 10.09 \\
\hline Income/Expenditure quartile 3 & $-81.86^{* * *}$ & 18.44 & -4.38 & 4.38 \\
\hline Income/Expenditure quartile 4 & $-73.61^{* * *}$ & 17.95 & 1.92 & 2.59 \\
\hline Income/Expenditure quartile 5 & $-60.12^{* * *}$ & 17.00 & 0.02 & 0.80 \\
\hline Other migrants in household & -186.68 & 40.59 & $-129.74^{* *}$ & 64.11 \\
\hline HH lives in urban area & -61.91 & 39.86 & $-135.44^{* *}$ & 63.19 \\
\hline Risk variables & Jointly sign ${ }^{* * *}$ & & Jointly sign ${ }^{* * *}$ & \\
\hline $\begin{array}{l}\text { Distance between } \mathrm{A} / \mathrm{M} \text { and } \\
\text { capital of destination }\end{array}$ & -223.62 & 218.56 & $281.62^{* * *}$ & 105.60 \\
\hline Migrant stock in destination & -0 & 0 & -0.00 & 0.00 \\
\hline Migrant entered legally & -12.37 & 39.16 & $-190.82^{* * *}$ & 62.90 \\
\hline $\begin{array}{l}\text { Unemployment rate of country } \\
\text { of destination }\end{array}$ & -74.36 & 79.71 & 2.86 & 42.05 \\
\hline Migrant abroad 1-5 years & $389.85^{* *}$ & 170.63 & $129.91^{*}$ & 68.60 \\
\hline Migrant abroad $>5$ years & $532.99^{* * *}$ & 170.29 & $138.21^{*}$ & 72.05 \\
\hline Constant & 2493.13 & 2328.95 & $-2349.20^{* * *}$ & 786.22 \\
\hline $\begin{array}{l}\text { Number of observations } \\
\text { Number of censored } \\
\text { observations }\end{array}$ & $734(36 \%)$ & & $\begin{array}{c}1029 \\
535(52 \%)\end{array}$ & \\
\hline Pseudo R2 & 0.11 & & 0.08 & \\
\hline McKelvey \& Zavoinas' R2 & 0.16 & & 0.14 & \\
\hline Log-likelihood ratio & 299.88 & & 121.34 & \\
\hline Log-likelihood probability & 0.00 & & 0.00 & \\
\hline
\end{tabular}

Base: migrant primary education or less, migrant location other, migrant abroad 0-1 year

${ }^{1}$ The income is used for Albania and expenditure is used for Moldova. Quartiles are equally spaced over the range of income/expenditures per capita, with 4 cut-off points with quartile 1 as the poorest households and quirtile 5 the richest households.

${ }^{*}$ significant at $10 \%$;* significant at $5 \%$; ${ }^{* * *}$ significant at $1 \%$ 
Most papers find some evidence for altruism, as defined by the theory. As predicted theoretically (see table 3.1) most papers find a positive relationship for the effect of the migrant's income on remittances ${ }^{35}$ and a negative relationship for the effect of the household's income on remittances ${ }^{36}$. For Albania we also find a positive and significant coefficient for the two lowest household expenditure splines (2 and 3). There is also a greater marginal effect for the poorest spline (3). Germenji, Beka, \& Sarris (2001) in an earlier study on Albania also find a positive relationship between remittances and migrant income using a tobit specification and a negative relationship between household income and remittances. Household size is also significant and positive for Albania, so larger households receive more remittances (which may show need). The household living in an urban area has a negative sign but is only significant in Moldova.

There are mixed results in Albania and Moldova with regard to education of the migrant. In Albaina, greater remittance sending is associated with secondary or vocational education (although only vocational is significant) and negative and insignificant for higher education. This is because more highly educated migrants (as compared to the base group with primary education) have a higher earnings capacity. In Moldova, all groups send more than primary education migrants but only secondary and higher are significant.

Still, the results of expenditure and education do not exclude other motives (like insurance and loan repayment). However, another variable that is often tested is the presence of other migrants in the household. More migrants in the household means that the migrant is not solely responsible for the wellbeing of the household and most papers do find this negative relationship ${ }^{37}$. We also find a negative and significant coefficient for both countries. Nevertheless, the value of such a result is doubtful as it can also be interpreted completely differently, as evidence for the bequest motive, see section 3.4 .2 below.

The significant variable married (which takes on the value 1 when the remitter is married) confirms for Albania what descriptive statistics already showed: married Albanian remitters remit less to their parents, as they also support their own families. In Moldova, married remitters remit more, as they migrate in order to remit to their wives and children back home. Other papers also find that married migrants remit more, while migrants whose spouses have joined them remit less. Apart from these common sense conclusions, it would be interesting to measure

\footnotetext{
${ }^{35}$ The sole exception is Lianos \& Cavoundis (2004)

${ }^{36}$ Exceptions are Lucas \& Stark (1985) and Itzingsohn (1995)

37 The following authors found positive relationships: Germenji, Beka, \& Sarris (2001), Hoddinott (1994) and Pleitez-Chavez (2004)
} 
changes in family dynamics, for example, the change in behaviour towards parents when a child gets married. Due to the scarcity of panel data this type of remitting behaviour has not been studied.

Length of stay in the host country is often used to measure (weakening) altruism. We find a positive effect for both Albania and Moldova. Most papers do not find evidence for remittance decay ${ }^{38}$, which shows that migrants generally keep links to their families and communities. Again, this non-surprising result can be interpreted in terms of more self-interested theories, for example, as investment at home due to future plans to return.

To succeed in measuring self-insurance only, Amuedo-Dorantes \& Pozo (2006) look at the risk level of the migrant only. The first measure of the migrant's risk level that we use is length of stay. As mentioned above, length of stay generally has a positive effect on remittances. This means that lower risk is accompanied with more remittances (so more insurance), which is some evidence against remittances as insurance Although few papers find a significant relationship for other measures of migrant risk (e.g. illegal employment), almost all of those that did, find a positive relationship. ${ }^{39}$ This means that migrants sent more remittances as insurance. For Albania, we find that the risk variables are jointly significant but that none of the risk variables other than duration of stay are significant by themselves. Lianos \& Cavoundis (2004) also find that Albanian migrants in more unstable employment remit higher amounts.

In Moldova, the risk variables are again jointly significant but more of the individual variables are also significant. Distance to the destination country is both positive and significant. The farther away a country is, the more it costs to get there so we assume that there is more risk of having to spend a lot of money to come home if the migration project fails. This is in line with the theory. If a migrant has entered the country legally, this is also associated with fewer remittances which give more evidence for the risk and insurance. That means that those migrants who have entered their destination countries illegally are sending more money home.

We have shown that when using the current straight-forward economic approach it is difficult to measure altruism as a separate motive because it overlaps with other motives and most authors have not been able to find good operators. It is possible to distinguish self-insurance, however, if good proxies for migrant risk are found, as these variables have opposite effects to altruism. We were only able to find moderate proxies for migrant risk, as our remittance receiving household

\footnotetext{
${ }^{38}$ The exceptions are: Banerjee (1984) and Funkhouser (1995)

${ }^{39}$ Only Durand, Kandel, Parrado, \& Massey (1996) and Konica (2006) find that those migrants with stable jobs are more likely to remit.
} 
database has little information on the remittance senders. This is a problem many authors face and that aggravates the theoretical problems.

\subsubsection{Measuring the bequest and co-insurance motive in Albania}

Next we use data on a household and community level to test for the bequest motive, co-insurance and the NELM theory in Albania. The model is described in equation 4.

$R_{i}^{*}=\alpha+\beta_{1} B_{i}+\beta_{2} C_{i}+\beta_{3} N_{i}+\varepsilon_{i}$

Where

Table 3.5 Variables and expected effects for Albania model

\begin{tabular}{|l|l|}
\hline Variable & Expected effect \\
\hline $\begin{array}{l}\text { R=amount of remittances received by the household over the } \\
\text { last } 12 \text { months }\end{array}$ & n.a. \\
\hline$M$ (Migrant variables) & control \\
\hline Age of migrant at departure & control \\
\hline Gender of migrant & control \\
\hline Marital status of the migrant & control \\
\hline Education of migrant & \\
\hline B (Bequest/ household variables) & $-/+$ \\
\hline Per capita income of household & $-/+$ \\
\hline Other migrants in household & + \\
\hline Age of household head & + \\
\hline Wealth index & + \\
\hline House inherited & \\
\hline House recently constructed & control \\
\hline Number of children in household & \\
\hline C (Co-insurance variables & + \\
\hline Adverse general household shocks & + \\
\hline $\begin{array}{l}\text { Adverse health shock experienced by household head or } \\
\text { spouse }\end{array}$ & - \\
\hline Whether household is borrowing money & \\
\hline$N$ (NELM variables) & control \\
\hline Household lives in urban/ rural area & + \\
\hline Community infrastructure index & + \\
\hline Credit possibility index & + \\
\hline Informal credit is a source of borrowing in this community & + \\
\hline Lack of employment opportunities in community & \\
\hline & \\
\hline
\end{tabular}


To measure the bequest motive, we look at the income of the household, if there are other migrants in the household, the age of the household head, the wealth of the household and whether the house was inherited by the current household. According to the theoretical literature, if the coefficient of income of the household has a positive sign this could show evidence for the bequest motive, since there is more to gain in inheritance. If remittances increase with the wealth of the household, then there is additional evidence for the bequest motive. If there are other migrants in the household, then sending more remittances could be a sign of trying harder to win the bequest; if the coefficient is negative, then it could be a sign of altruism or the fact that the migrant does not think they will inherit, so they do not send more remittances. If the higher age of the household head coincides with higher remittances, this could be evidence for the bequest motive, because the probability of the death is higher (Brown, 1997).

Many of the variables trying to measure the bequest motive are abstract and farfetched. Therefore, we include some more specific variables. If the house has been inherited in previous generations, then the migrant can assume that this will happen again, which would mean greater remittances. Some migrants build houses for their parents, which they expect to inherit, therefore, we also included a dummy for newly constructed house.

To test co-insurance of a household, we look at adverse shocks to the household (e.g. loss of crops), health shocks experienced by the household head and or spouse during the past month and whether the household has loans. If either of the coefficients for the variables for shocks have a positive sign, then there is evidence for insurance or altruism. If the coefficient for the borrowing money variable is negative then the household has other means to insure in case of a shock, so coinsurance (i.e. remittances) is not necessary. If the sign is positive it could be an indication of altruism, as the loan could be a sign of household need.

To test the more general hypothesis of the NELM, we use the variables community infrastructure, formal and informal credit possibilities, the population of the community, employment possibilities in the community and whether or not the household is in a rural or urban community, thus following the approaches of Durand et al (1996) and Sana \& Massey (2005) as much as possible. If the coefficient of community infrastructure has a positive sign, this is evidence of the NELM, since there needs to be a basic infrastructure if the household wants to invest. If it is negative, then it shows altruism because of need. If the coefficient of formal credit possibility has a negative sign this is evidence against NELM. There are possibilities to obtain money elsewhere, so there is less need for a co-insurance arrangement. If the coefficient of informal credit has a positive sign, then this shows an underdeveloped financial sector, i.e. there is need for co-insurance and evidence for the NELM. As in a larger community, there are more opportunities 
for investments and jobs other than through migration so fewer remittances will be sent as part of a co-insurance arrangement. The sign for the coefficient for lack of employment possibilities should be positive for NELM and altruism. As can be seen from the above explanation, NELM variables mostly test investment possibility variables; so NELM also tests for the investment motive in some respect. 
Table 3.6 Results of Tobit regression for Albania model

\begin{tabular}{|c|c|c|}
\hline & Marginal effects coeff. & std. error \\
\hline Migrant variables & Joinlty significant ${ }^{* * *}$ & \\
\hline Age of migrant & $12.63^{* * *}$ & 3.09 \\
\hline Gender of migrant & $456.32^{* * *}$ & 45.12 \\
\hline Marital status of the migrant & $-159.53^{* * *}$ & 49.55 \\
\hline Migrant secondary education & 45.21 & 46.10 \\
\hline Migrant vocational education & 80.60 & 61.29 \\
\hline Migrant higher education & -24.08 & 76.25 \\
\hline HH variables (bequest) & Joinlty significant*** & \\
\hline Income/Expenditure quartile 1 & $-76.92^{* * *}$ & 21.42 \\
\hline Income/Expenditure quartile 2 & $-76.26^{* * *}$ & 19.55 \\
\hline Income/Expenditure quartile 3 & $-70.40^{* * *}$ & 18.70 \\
\hline Income/Expenditure quartile 4 & $-63.54^{* * *}$ & 18.25 \\
\hline Income/Expenditure quartile 5 & $-52.98^{* * *}$ & 17.18 \\
\hline Morris score index & $148.65^{* * *}$ & 35.56 \\
\hline Age of HH head & $-9.85^{* * *}$ & 2.75 \\
\hline HH owns house & $-169.17^{*}$ & 88.21 \\
\hline Other migrants in $\mathrm{HH}$ & $-146.62^{* * *}$ & 41.80 \\
\hline Number of elderly in $\mathrm{HH}$ & -10.62 & 30.40 \\
\hline Co-insurance variables & Not jointly significant & \\
\hline HH has property shock & 26.48 & 224.78 \\
\hline HH has job shock & -76.34 & 201.29 \\
\hline HH has illness shock & 110.81 & 131.50 \\
\hline NELM variables & Jointly significant* & \\
\hline Household lives in urban/ rural area & $-106.49^{*}$ & 60.86 \\
\hline Community infrastructure index & -30.33 & 105.37 \\
\hline Credit possibility index & -24.37 & 30.51 \\
\hline $\begin{array}{l}\text { Informal credit is a source of borrowing in this } \\
\text { community }\end{array}$ & 24.77 & 58.86 \\
\hline Lack of employment opportunities in community & $117.86^{* *}$ & 47.54 \\
\hline Constant & -529.98 & 257.11 \\
\hline Number of observations & 1935 & \\
\hline Number of censored observations & $708(37 \%)$ & \\
\hline Pseudo R2 & 0.12 & \\
\hline McKelvey \& Zavoinas' R2 & 0.16 & \\
\hline Log-likelihood ratio & 294.65 & \\
\hline Log-likelihood probability & 0.000 & \\
\hline
\end{tabular}

Base: migrant primary education or less

${ }^{*}$ significant at $10 \%$; ${ }^{* *}$ significant at $5 \%$; ${ }^{* * *}$ significant at $1 \%$ 
In theory, migrants with a bequest motive should be more likely to send remittances and send greater sums of remittances if their parents are wealthy (e.g. they own land) and have a higher income. ${ }^{40}$ Lucas \& Stark (1985) do find evidence for the bequest motive: sons in Botswana remit more to families that have larger herds and if the household has a larger income (as predicted by the theory). In our regression the household bequest variables are highly significant as a group. Germenji, Beka, \& Sarris (2001) in an earlier study on Albania find a negative relationship between household wealth and remittances but with new data we find the opposite, the poorest are remitting the most. As Brown (1997) argued, the positive and highly significant sign for age of household head could also indicate a bequest motive. The older the household head is, the closer he is to death and the sooner a potential inheritance. A migrant, thus, remits more to be on favourable terms with the household head. This could also be a sign of altruism because the household head is elderly and needs more support. Unfortunately, we find the opposite result which does not support the bequest motive.

Whether remittances are sent as part of a co-insurance contract between migrants and households can be measured by analysing the effect of household shocks and migrant (income, employment and living) risk on remittances. According to most studies that included household shocks, shocks of the household (e.g. illness) lead to a higher probability of remittances and larger sums of remittances.41 Unfortunately, this cannot be distinguished from altruistic behaviour. In our regression the co-insurance variables are not significant as a group. This means that the household has other means to insure in case of a shock, so co-insurance (i.e. remittances) is not necessary. ${ }^{42}$

Durand, Kandel, Parrado, \& Massey (1996) find that migrants are more likely to remit to economically dynamic and entrepreneurial communities, which suggests that remittances are sent as co-insurance under the right conditions. Since the migration and remitting decision are highly linked, we expected the NELM to be highly significant since they also influence the migration decision. The joint NELM variables are significant at the $10 \%$ level. The main significant NELM variable is lack of employment opportunities in the community which has a positive sign.

\footnotetext{
${ }^{40}$ Some papers do find this relationship (Briere, Janvry, Lambert, \& Sadoulet, 1997; Hoddinott, 1994; Lucas \& Stark, 1985; Pleitez-Chavez, 2004; Schrieder \& Knerr, 2000), but others do not (Durand, Kandel, Parrado, \& Massey, 1996; Germenji, Beka, \& Sarris, 2001; Holst \& Schrooten, 2006; Osaki, 2003).

${ }^{41}$ Only Halliday (2005) finds that for an earthquake shock, less remittances are sent, unlike for an agricultural shock. He attributes this to the fact that households cope with the earthquake by retaining family members at home to help with rebuilding.

${ }^{42}$ As a similar test of other types on insurance we included social security income in an earlier regression but it was not significant.
} 
Again we find that most variables used to measure the different motives are too general and therefore multi-interpretable. Only the NELM accounts for the origin community development and more research should be done in this direction as it influences both the decision to migrate and the decision to remit, which are interlinked for economic migrants.

\subsubsection{Measuring loan repayment in Moldova}

In the final analysis we use only Moldovan data and test for another theoretical motive to remit, namely loan repayment. We estimate the following model:

$$
R_{i}^{*}=\alpha+\beta_{1} M_{i}+\beta_{2} H_{i}+\beta_{3} L_{i}+\varepsilon_{i}
$$

Where

Table 3.7 Variables and expected effects for Moldova model

\begin{tabular}{|l|l|}
\hline Variable & $\begin{array}{l}\text { Expected } \\
\text { effect }\end{array}$ \\
\hline $\begin{array}{l}\text { R=amount of remittances received by the household } \\
\text { over the last } 12 \text { months }\end{array}$ & n.a. \\
\hline$M$ (Migrant variables) & \\
\hline Age of migrant at departure & control \\
\hline Gender of migrant & control \\
\hline Marital status of the migrant & control \\
\hline Country of migrant destination & control \\
\hline Duration of migration, in categories & control \\
\hline H (Household variables) & \\
\hline Household size & + \\
\hline Per capita expenditures of household & - \\
\hline Other migrants in household & - \\
\hline Household lives in urban/ rural area & control \\
\hline L (Loan repayment variables) & \\
\hline Education of migrant & + \\
\hline Education of household head & + \\
\hline Motivation to remit debt & + \\
\hline Cost of migration & + \\
\hline
\end{tabular}


Loan repayment here refers to the repaying of education or the repayment of the financing of migration. The main variables we consider when testing this motive are: education of the household head, education of the migrant, whether debt is the motivation to remit and the cost of migration. The higher the education of the household head, the better the enforcement of loan repayment (see Hoddinott (1992)). If the migrant is highly educated, then the remittances sent by the migrant should be higher due to the greater cost of his education (Poirine, 1997). One of the motivations to remit can be to pay back a loan. For this we use the variable, whether debt repayment was a main motivation to remit. 
Table 3.8 Results of Tobit regression for Moldova model

\begin{tabular}{|c|c|c|}
\hline & $\begin{array}{l}\text { Marginal } \\
\text { effects coeff. }\end{array}$ & Std.error \\
\hline \multicolumn{3}{|l|}{ Migrant variables } \\
\hline Age of migrant & $11.73^{* * *}$ & 3.40 \\
\hline Gender of migrant & 109.30 & 74.28 \\
\hline Marital status of the migrant & -35.44 & 81.92 \\
\hline Migrant secondary education & -148.46 & 193.39 \\
\hline Migrant vocational education & -142.81 & 191.00 \\
\hline Migrant higher education & -54.47 & 202.68 \\
\hline Migrant in CIS & -166.78 & 121.19 \\
\hline Migrant in EU & 47.73 & 130.90 \\
\hline Migrant abroad $1-5$ years & 47.36 & 90.92 \\
\hline Migrant abroad $>5$ years & 108.53 & 96.21 \\
\hline \multicolumn{3}{|l|}{ Household variables } \\
\hline $\mathrm{HH}$ size & -13.81 & 27.12 \\
\hline Income/Expenditure quartile 1 & -72.87 & 74.16 \\
\hline Income/Expenditure quartile 2 & $-25.55^{*}$ & 13.31 \\
\hline Income/Expenditure quartile 3 & -3.50 & 5.85 \\
\hline Income/Expenditure quartile 4 & 2.35 & 3.21 \\
\hline Income/Expenditure quartile 5 & -.051 & 1.01 \\
\hline Other migrants in hh & $-235.16^{* * *}$ & 80.82 \\
\hline $\mathrm{HH}$ lives in urban area & $-202.05^{* *}$ & 78.91 \\
\hline \multicolumn{3}{|l|}{ Loan repayment variables } \\
\hline $\begin{array}{l}\text { Household head secondary } \\
\text { education }\end{array}$ & $425.12^{* * *}$ & 148.07 \\
\hline $\begin{array}{l}\text { Household head vocational } \\
\text { education }\end{array}$ & $311.18^{* *}$ & 144.42 \\
\hline Household head higher education & 173.76 & 170.96 \\
\hline Cost of migration & $0.09^{* * *}$ & 0.03 \\
\hline Motive to remit (debit) & 413.00 & 849.94 \\
\hline Constant & -227.76 & 294.77 \\
\hline Number of observations & 723 & \\
\hline Number of censored observations & $231(32 \%)$ & \\
\hline Pseudo R2 & 0.08 & \\
\hline McKelvey \& Zavoinas' R2 & 0.13 & \\
\hline Log-likelihood ratio & 84.79 & \\
\hline Log-likelihood probability & 0.000 & \\
\hline
\end{tabular}

1 The income is used for Albania and expenditure is used for Moldova. Quartiles are equally spaced over the range of income/expenditures per capita, with 4 cut-off points with quartile 1 as the poorest households and quirtile 5 the richest households..

* significant at $10 \%$ level

** significant at 5\% level

*** significant at $1 \%$ level 
Loan repayment can be measured by looking at migration costs and the education level of the migrant. Migrants with a higher education level could be sending remittances to repay the investment their parents have made in their education. Even from a sociological perspective this motive seems justified, as the contract may be implicit and based on a feeling of duty. However, this variable could also measure income effects. Almost all authors find a positive relationship between the migrant's education level and remittances ${ }^{43}$ and we find a non-significant relationship for Moldova, but due to the weak operationalisation the evidence for the education loan repayment motive is not convincing. The education of the household head is also not directly in line with the theory for loan repayment. Households with household heads with secondary or vocational education receive more remittances than those with heads that only have primary education. Higher educated household heads are no significant.

It is possible that those migrants that received help from their family in financing migration send more remittances as a loan repayment. This is confirmed by all empirical studies that find a significant relationship. The cost of migration is significant and positive, so destinations that were more expensive to reach mean higher remittances sent back. The main motive to remit (debt) variable is positive but not significant. The loan repayment variables in our analysis are, however, jointly significant. Overall we do not have only modest evidence for loan repayment.

\subsection{Conclusions}

We have shown that migration and remittances are important for both Albania and Moldova, but that they differ in terms of migration and remitting patterns. Males are the majority of migrants in both countries and remittances are sent to all income groups. In Albania, higher amounts are sent to the richer households. Albanian men send higher amounts of remittances, probably due to cultural practice, while in Moldova women send higher amounts. In Albania, migration is longer term, especially compared to Moldova, where migration is often seasonal and in the direction of Russia. In both countries, migrants who have been abroad longer send more remittances. Education has a clear pattern in Moldova, the more educated send more remittances but there is a more mixed situation in Albania (the first three quartiles all send similar amounts but the richest sends the least).

To investigate the different theoretical motives to remit more closely, we applied three different econometric models, following the theoretical and empirical

\footnotetext{
${ }^{43}$ Only two papers find a negative relationship between the migrant's education level and the probability of sending remittances: Durand, Kandel, Parrado, \& Massey (1996) and Osaki (2003).
} 
literature on the motivations to remit. While we are able to find evidence for some motivations, the analysis resulted in inconclusive results, very much in line with the literature.

It is clear that the causes and patterns of migration in Albania and Moldova influence the remitting behaviour. Geographical location, economic possibilities and family situations determine where, for long and under which circumstances a migrant can migrate and send remittances. It is exactly the effect of the selectivity of migrants on remittance behaviour that needs to be studied further. Migrating and remitting are joint decisions in many cases and looking at the motivations to remit exclusively biases the results and leaves out vital explanatory factors. Furthermore, we need to differentiate between the desire and the capacity to remit.

The literature finds some significant individual and household characteristics that influence remitting patterns. Migrant age, sex, marital status, education, household income, wellbeing and migration patterns are influential in determining the amount of remittances received. While there is agreement on some (common sense) remitting motives, e.g. altruism towards spouses, many of the results remain ambiguous due to a number of methodological problems. First, the decision to remit is often linked to the decision to migrate, which comes with its own methodological problems, for example selection bias. This is completely neglected in the motivations to remit literature. Furthermore, due to the overlapping theories and data limitations, most authors were not able to find solid variables to measure the different motives. Consequently, in most cases the results are weak and multi-interpretable.

We have shown that one needs to be careful in declaring migrant's motives to remit and to draw conclusions from a few variables that can be interpreted in different ways. It is not possible to give a satisfying answer to this question on a general level and even on a country-specific level problems arise, as it is difficult to test these motives empirically. Not only do the definitions of the motivations to remit overlap, but in real life behaviour the dichotomy altruism versus self-interest is not as sharply defined as in theory. Furthermore, a migrant might have more than one motive in mind. We, therefore, need to revise economic theories of motivations to remit to include the social context and acknowledge the full complexity of a migrant's decision to remit. 


\subsection{References}

Al-Ali, N., R. Black, et al. (2001). "The limits to 'transnationalism': Bosnian and Eritrean refugees in Europe as emerging transnational communities." Ethnic and Racial Studies 24(4): 578-600.

Amuedo-Dorantes, C. and S. Pozo (2006). "Remittances as insurance: evidence from Mexican immigrants." Journal of Population Economics 19(2): 227254.

Banerjee, B. (1984). "The probability, size and uses of remittances from urban to rural areas in India." Journal of Development Economics 16(3): 293.

Barjaba, K. and R. King (2005). Introducing and theorizing Albanian migration. New Albanian Migration. R. King, N. Mai and S. Schwandner. Brighton, Sussex Academic Press: 1-28.

Briere, B. d. 1., A. d. Janvry, et al. (1997). "Why do migrants remit? An analysis for the Dominican Sierra." FCND Discussion Paper 37.

Brown, R. P. C. (1997). "Estimating remittance functions for Pacific Island migrants." World Development 25(4): 613-627.

CBS-AXA, C. (2005). Migration and Remittances in Moldova. Chisinau.

Cornea, G. A., F. Izman, et al. (2005). Economics Policies for Growth, Employment and Poverty Reduction: Moldova in Transition, United Nationals Development Program Bureau for Development Policy.

Cox, D. (1987). "Motives for Private Income Transfers." Journal of Political Economy 95(5).

Cox, D., E. Jimenez, et al. (1997). "Family Safety Nets and Economic Transition: A Study of Worker Households in Poland." Review of Income \& Wealth 43(2): 191-209.

Cox, D. and O. Stark (1994). "Intergenerational transfers and the demonstration effect." Boston College Working Papers in Economics 329.

Craciun, C. (2006). Migration and Remittances in the Republic of Moldova: Empirical Evidence at Micro Level. Economics, National University "KyivMohyla Academy". Master of Arts in Economics.

Durand, J., W. Kandel, et al. (1996). "International migration and development in Mexican communities." Demography 33(2): 249-264.

Funkhouser, E. (1995). "Remittances from International Migration: A Comparison of El Salvador and Nicaragua." The Review of Economics and Statistics 77(1): 137.

Germenji, E., I. Beka, et al. (2001). Estimating Remittance Functions of Rural-Based Albanian Emigrants Phare ACE project P97-8158-R Micro-economic Analysis of Farm Restructuring in Central and Eastern Europe. 
Görlich, D., T. O. Mahmoud, et al. (2007). "Explaining Labour Market Inactivity in Migrant-Sending Families: Housework, Hammock, or Higher Education " Kiel Working Paper 1391.

Görlich, D. and C. Trebesch (2008). "Mass Migration and Seasonality: Evidence on Moldova's Labour Exodus." Review of World Economics 44(1): 107-133.

Government of the Republic of Moldova (2006). Annual Evaluation Report on the Implementation of the Economic Growth and Poverty Reduction Strategy, 2005. Chisinau, Government of the Republic of Moldova.

Gubert, F. (2002). "Do migrants insure those who stay behind? Evidence from the Kayes area (Western Mali)." Oxford Development Studies 30(3): 267-287.

Hagen-Zanker, J. and M. Siegel (2007). "The determinants of remittances: A review of the literature." MGSOG Working Paper 2007/3.

Halliday, T. (2005). "Migration, Risk and Liquidity Constraints in El Salvador." University of Hawaii at Manoa, Department of Economics Working Paper 05-11.

Hoddinott, J. (1992). "Modeling remittance flows in Kenya." Journal of African Economies 1(2): 206-232.

Hoddinott, J. (1994). "A Model of Migration and Remittances Applied to Western Kenya." Oxford Economic Papers 46(3): 459-476.

Holst, E. and M. Schrooten (2006). "Migration and money- What determines remittances? Evidence from Germany." Institute of Economic Research, Hitotsubashi University, Discussion Paper Series 477.

IMF (2006). Albania: Selected Issues. IMF Country Report No 06/285. Washington, D.C.

INSTAT (2004). Migration in Albania- Population and Housing Census 2001. Tirana.

Itzigsohn, J. (1995). "Migrant Remittances, Labor Markets, and Household Strategies: A Comparative Analysis of Low-Income Household Strategies in the Caribbean Basin." Social Forces Vol. 72(No. 2).

King, R. (2005). "Albania as a laboratory for the study of migration and development." Journal of Southern Europe and the Balkans 7: 133-155.

King, R., M. Dalipaj, et al. (2006). "Gendering Migration and Remittances: Evidence from London and Northern Albania." Population, Space and Place 12: 409434.

Konica, N. (2006). The Emigration Experience and its Impact on the Albania Economy in Early Transition Period. On Eagle's Wings: The Albanian Economy in Transition. D. Bezemer. New York, Nova Science Publishers.

Lianos, T. P. and J. Cavounidis (2004). Immigrant remittances, stability of employment and relative deprivation. New Perspectives on Albanian Migration and Development, Korçë, Albania.

Liu, Q. and B. Reilly (2004). "Income transfers of Chinese rural migrants: some empirical evidence from Jinan." Applied Economics 36: 1295-1313. 
Lucas, R. E. B. and O. Stark (1985). "Motivations to Remit: Evidence from Botswana." The Journal of Political Economy 93(5): 901-918.

Osaki, K. (2003). "Migrant remittances in Thailand: Economic necessity or social norm." Journal of Population Research 20(2): 203-222.

Pleitez-Chavez, R. A. (2004). Remittances as a strategy to cope with systemic risk: panel results from rural households in El Salvador. Agricultural, Environmental and Development Economics. Ohio, Ohio State University. Doctor of Philosophy.

Poirine, B. (1997). "A theory of remittances as an implicit family loan arrangement." World Development 25(4): 589-611.

Rapoport, H. and F. Docquier (2005). "The Economics of Migrants' Remittances." IZA Discussion Paper Series No.1531.

Sana, M. and D. S. Massey (2005). "Household Composition, Family Migration, and Community Context: Migrant Remittances in Four Countries." Social Science Quarterly 86(2): 509-528.

Schrieder, G. and B. Knerr (2000). "Labour Migration as a Social Security Mechanism for Smallholder Households in Sub-Saharan Africa: The Case of Cameroon." Oxford Development Studies 28(2): 223-236.

Vullnetari, J. (2007). "Albanian migration and development: state of the art review." IMISCOE Working Paper 18.

Zwager, N. d., I. Gedeshi, et al. (2005). Competing For Remittances, International Organisation for Migration Tirana. 


\section{Appendix 3.1}

Summary statistics table Moldova

Variable

Migrant remittances USD

Age of migrant

male

married

secondary migrant

Vocational migrant

University migrant

CIS

EU

Household size

Expenditure per cap USD

(Spline 1)

Expenditure per cap USD

(Spline 2)

Expenditure per cap USD

(Spline 3)

Other migrants in the hh

Urban

Between 1 and 5 years

abroad

More than 5 years abroad

migration cost

loan repayment

Secondary hhh

Vocational hhh

University hhh

Distance log

Migrant stock at destination

Migrant entered legally

Unemployment rate of

country of destination
Obs

1843

1843

1843

1842

1820

1820

1820

1843

1843

1843

1843

1843

1843

1843

1843

1607

1481

1327

1022

1822

1822

1822

1770

1770

1282

1770
31.99

Mean

450

36

0.60

0.69

0.38

0.37

0.18

0.63

0.23

4.29

0.37

0.02

0.25

0.28

0.41

0.42

728.08

0.00

0.36

0.38

0.14

7.06

181,884

0.77

7.59
Std. Dev. Min Max

$\begin{array}{rrr}1274 & 0 & 75348 \\ 11 & 6 & 99 \\ 0.49 & 0 & 1 \\ 0.46 & 0 & 1 \\ 0.49 & 0 & 1 \\ 0.48 & 0 & 1 \\ 0.39 & 0 & 1 \\ 0.48 & 0 & 1 \\ 0.42 & 0 & 1 \\ 1.49 & 1 & 12\end{array}$

$\begin{array}{lll}41.26 & 0.78 & 277.81\end{array}$

$\begin{array}{lll}8.14 & 0 & 277.09\end{array}$

0.79

0.43

0.45

0.49

0.49

1331.38

0.03

0.48

0.48

0.34

0.38

127,273

0.42

0.89

4.6

11.1 
Summary statistics table Albania

\begin{tabular}{|c|c|c|c|c|c|}
\hline & Obs & Mean & Std. dev. & Min & Max \\
\hline Migrant remittances in USD & 2034 & 772.35 & 1525.60 & 0 & 24907.8 \\
\hline Age of migrant & 2034 & 31.12 & 8.34 & 16 & 69 \\
\hline Gender of migrant & 2034 & 0.65 & 0.48 & 0 & 1 \\
\hline Marital status of the migrant & 2034 & 0.66 & 0.47 & 0 & 1 \\
\hline Migrant secondary education & 2034 & 0.31 & 0.46 & 0 & 1 \\
\hline Migrant vocational education & 2034 & 0.13 & 0.34 & 0 & 1 \\
\hline Migrant higher education & 2034 & 0.08 & 0.28 & 0 & 1 \\
\hline Migrant in Italy & 2034 & 0.39 & 0.49 & 0 & 1 \\
\hline Migrant in Greece & 2034 & 0.40 & 0.49 & 0 & 1 \\
\hline Expenditure spline 1 & 2032 & 4.16 & 0.12 & 3.36 & 4.20 \\
\hline Expenditure spline 2 & 2032 & 0.50 & 0.40 & 0 & 1.39 \\
\hline Expenditure spline 3 & 2032 & 0.00 & 0.04 & 0 & 0.90 \\
\hline Morris score index & 2034 & 2.60 & 0.59 & 0.04 & 3.48 \\
\hline Age of $\mathrm{HH}$ head & 2034 & 61.46 & 9.83 & 22 & 96 \\
\hline HH owns house & 2034 & 0.95 & 0.21 & 0 & 1 \\
\hline Other migrants in $\mathrm{HH}$ & 2034 & 0.71 & 0.45 & 0 & 1 \\
\hline Number of elderly in $\mathrm{HH}$ & 2034 & 2.39 & 1.44 & 0 & 10 \\
\hline HH has property shock & 2034 & 0.01 & 0.08 & 0 & 1 \\
\hline HH has job shock & 2034 & 0.01 & 0.09 & 0 & 1 \\
\hline HH has illness shock & 2034 & 0.02 & 0.14 & 0 & 1 \\
\hline $\begin{array}{l}\text { Household lives in urban/ rural } \\
\text { area }\end{array}$ & 2034 & 0.53 & 0.50 & 0 & 1 \\
\hline $\begin{array}{l}\text { Community infrastructure } \\
\text { index }\end{array}$ & 1937 & 0.69 & 0.30 & 0 & 1 \\
\hline Credit possibility index & 1937 & 0.76 & 0.63 & 0 & 2 \\
\hline $\begin{array}{l}\text { Informal credit is a source of } \\
\text { borrowing in this community }\end{array}$ & 1935 & 0.88 & 0.32 & 0 & 1 \\
\hline $\begin{array}{l}\text { Lack of employment } \\
\text { opportunities in community }\end{array}$ & 1935 & 0.78 & 0.42 & 0 & 1 \\
\hline $\begin{array}{l}\text { Distance between } \mathrm{A} / \mathrm{M} \text { and } \\
\text { capital of destination }\end{array}$ & 2034 & 6.63 & 0.71 & 3.21 & 8.91 \\
\hline Migrant stock in destination & 2034 & $233,726.2$ & $148,239.2$ & 6281 & 403,856 \\
\hline Migrant entered legally & 2034 & 0.55 & 0.50 & 0 & 1 \\
\hline $\begin{array}{l}\text { Unemployment rate of country } \\
\text { of destination }\end{array}$ & 2034 & 8.55 & 1.24 & 5.1 & 11.1 \\
\hline Migrant abroad 1-5 years & 2034 & 0.38 & 0.49 & 0 & 1 \\
\hline Migrant abroad >5 years & 2034 & 0.61 & 0.49 & 0 & 1 \\
\hline
\end{tabular}


Chapter 4: What Determines the Choice of Transfer Channel for Migrant Remittances? The Case of Moldova
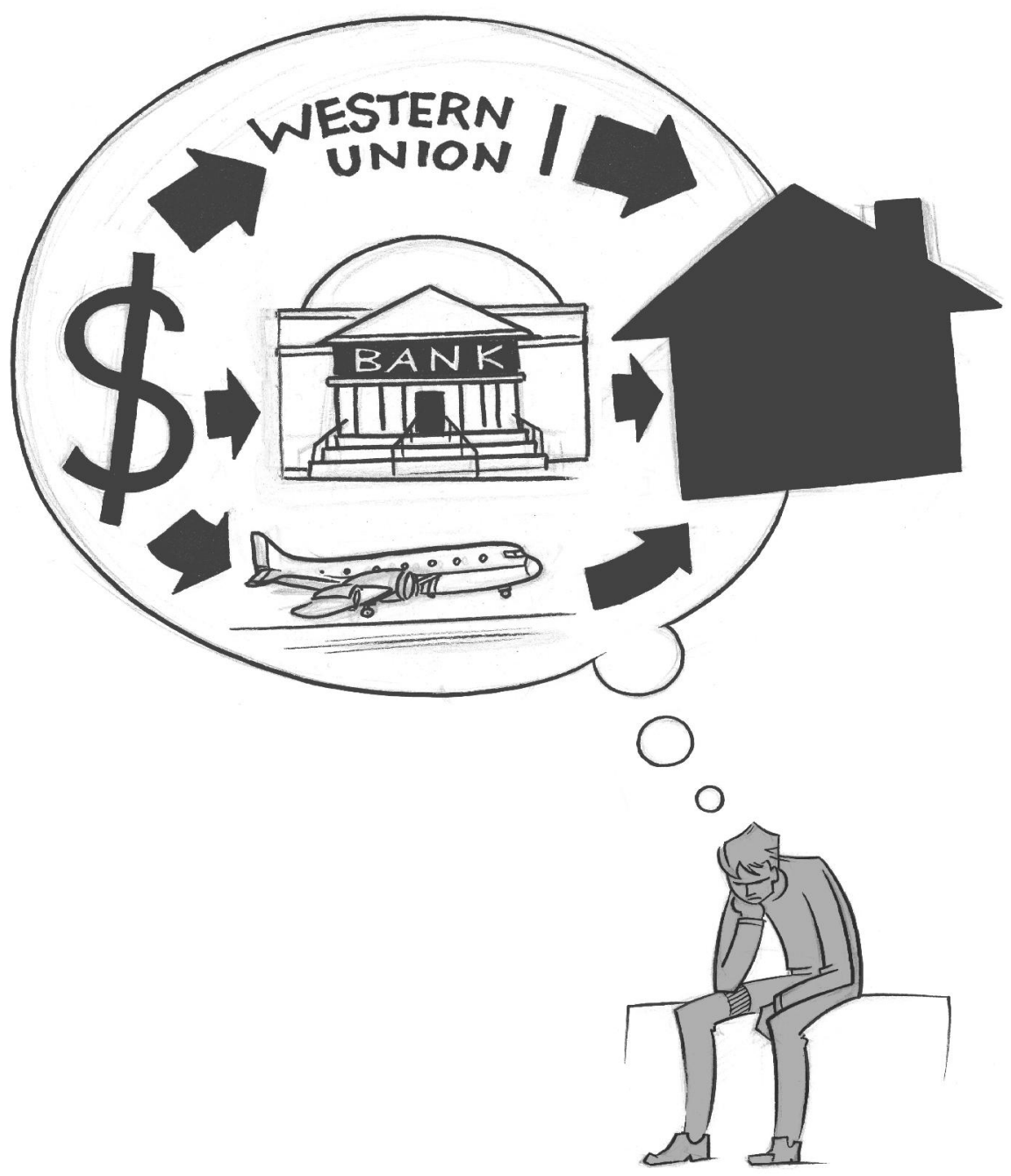


\subsection{Introduction ${ }^{4 *}$}

In many developing and transition economies, remittances from labor migrants constitute a large share of households' disposable incomes. Economy-wide, remittances are often a major source of external finance that surpasses official development assistance and foreign direct investment. Nevertheless, cross-country studies of the combined impact of migration and remittances on domestic GDP growth find ambiguous effects (for a recent survey see Chami, Barajas et al., 2008). Clearly, migration and remittances sustain consumption but do not automatically lead to higher investment and output growth. Therefore, national governments, international financial institutions and other donors are now searching for policies that will harness remittances for the sustainable economic development of migrants' home countries.

The transfer channels used by migrants to send remittances are one important area on which policy debates have focused. Globally, a large share of remittances is transferred not through the banking system or established money transfer operators, but through various informal channels. At the same time, there are several reasons why remittances sent through formal financial institutions (particularly banks) are more likely than informal transfers to promote economic development.

First, if recipients have remittances deposited into bank accounts or at least collect remittances from bank offices, a growing number of individuals and households are brought into regular contact with the formal financial sector (Spatafora, 2005). A range of banking services will be offered to the formerly unbanked and the availability of loanable funds will increase economy-wide, promoting financial development.

Second, greater use of formal transfer channels is likely to help reduce transfer fees. The provision of international payment services in developing countries with

\footnotetext{
${ }^{44}$ This chapter is based on joint work with Matthias Lücke by the same name.

* This chapter has benefited from comments by Jorgen Carling and seminar participants at the Remittances and transnational livelihoods $\mathrm{PhD}$ course, International Peace Research Institute (PRIO) Oslo, Norway, October 31-November 3, 2007.; $3^{\text {rd }}$ IMISCOE PhD Workshop in Hamburg at the Hamburg Institute of International Economics (HWWI), Germany, February 6-8, 2008.; Harvard University, Wiener Center for Social Policy and Inequality Work in Progress Seminar, February 28, 2008.; 5th Annual IMISCOE Conference, Bilbao, Spain, 9-12 September 2008 and the Lille EQUIPPE 1 economics seminar January 20, 2009. Research assistance by Ulrike Zirpel at the Kiel Institute is gratefully acknowledged. The household survey data used in this paper are available for purposes of research from the International Organization for Migration, Moldova Office.
} 
limited public infrastructure is bound to be subject to economies of scale and scope. Therefore, a larger number of formal remitters would reduce the cost per transaction, permitting fees to be reduced as competition among suppliers intensifies.

Third, several commercial banks in developing countries have been able to securitize either future flows of remittances or their fee income from such transactions, allowing the banks to attain investment grade ratings, reduce borrowing costs, and expand lending (OECD, 2007). Such operations further promote financial sector development.

Finally, informal international transfer networks such as the Hawala system have at times been suspected of providing cover for money laundering or the financing of terrorism (Jost \& Sandhu, 2000). Whatever the factual basis of such suspicions, authorities are likely to respond in ways that will disrupt the transfer of remittances. By contrast, transfers through established money transfer operators are transparent and therefore not subject to wholesale charges of criminal involvement.

In spite of the benefits derived from the use of formal transfer channels and a variety of government and donor policies encouraging their use, informal transfers are still prominent in many remittance-receiving countries. These include organized transfer services by third parties, such as the hawala system or other unregistered or unlicensed operators (minibus drivers, train conductors, etc.), as well as cash (foreign exchange) transported personally by migrants themselves, relatives, friends, etc. The persistence of informal transfers raises the questions of (i) what drives the choice of transfer channel by migrants and their families and (ii) whether policy interventions can or should be designed to promote the use of formal transfers.

In this chapter, we study the choice of transfer channels by households in Moldova. Migration is a mass phenomenon in Moldova; up to one in three households receives remittances, mostly from a current household member working abroad. The government is encouraging the use of formal transfer channels, including not taxing remittances and keeping the necessary paperwork for money transfers to individuals (as opposed to businesses) manageable. Nevertheless, in our 2006 data from a nationally representative household survey, only about one half of remitter-recipient pairs report that they use formal transfers as their predominant channel. Around one third rely on personal delivery of foreign exchange cash by the migrants themselves or other trusted individuals, while the remainder use informal services such as minibus drivers and train conductors. 
We conduct a multinomial logit analysis of the determinants of the choice of the predominant transfer channel for each remitter-recipient pair, focusing on three groups of explanatory variables: (i) socioeconomic characteristics of the migrant and the recipient household, including education, gender, urban vs. rural, consumption level, migration networks at household location; (ii) characteristics of the migration process, such as the host country, legal residence status, and for how long the migrant stays abroad; and (iii) financial information, such as whether the household has a current bank account, whether remittances are sent regularly, and the primary motivation for choosing a particular channel (cost, speed, convenience, etc.). Depending on which variables are found to dominate the choice of transfer channel, the next steps are to determine whether market failures or external effects have a large impact on household decisions and whether appropriate policy interventions can be designed.

This chapter is structured as follows. In Section 2, we review broad trends in migration and remittances in Moldova, explain characteristic features of our dataset, and provide descriptive statistics on key groups of migrants and their remittance behavior. Section 3 explains the database we use. In Section 4, we summarize previous studies on the choice of transfer channels and describe our empirical approach. In Section 5, we present our econometric model and in Section 6 we emphasis our empirical findings. Section 7 draws out the policy implications of our results.

\subsection{Labor migration and remittances in Moldova since 1999}

Although labor migration from Moldova is a mass phenomenon today, it is a fairly recent development. A good measure of the prevalence of migration is the number of Moldovans who work abroad while still belonging to a household in Moldova (Figure 4.1). The best information available suggests that there were roughly 50,000 Moldovans working abroad in 1999 at any given point in time, while in 2007 there were close to $350,000 .{ }^{45}$ Since seasonal migration is substantial, the total number of migrants abroad within any 12-month-period is at least one third higher. According to balance of payments statistics, remittances have grown along with the number of migrants to more than one third of Moldova's GDP in 2007 (Figure 4.2). Also according to balance of payments statistics, somewhere between one half and two thirds of remittances are transmitted through formal channels (see

\footnotetext{
45 The Labor Force Survey, on which these estimates are based, was thoroughly revised starting from 2006, leading to a lower estimate of the number of migrants. To present an internally consistent picture in Figure 1, we have revised pre-2006 figures downward in line with the discrepancy between the "old" LFS and the 2004 Census on which the "new" LFS estimates from 2006 are based.
} 
Luecke, Mahmoud \& Pinger, 2007 for a more detailed discussion of data quality and coverage). ${ }^{46}$

Figure 4.1 Labour migrants, 1999-2008 (thousands; 1999-2005 adjusted)

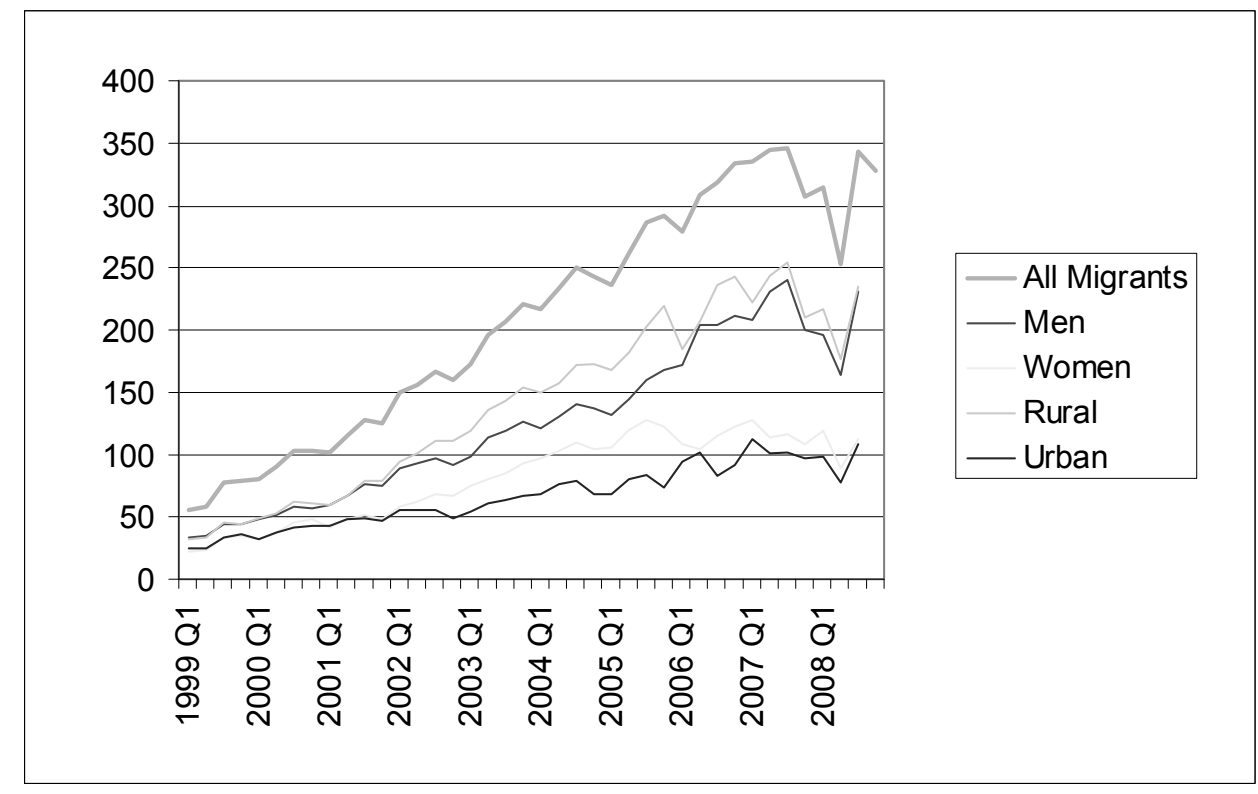

${ }^{46}$ These balance of payments data correspond to the sum of credit items in the compensation of employees and workers' remittances accounts. The totals reflect electronic transfers through the banking system, including payments through money transfer operators (MTOs) according to the methodology of the National Bank of Moldova, as well as estimates of informally transmitted remittances. 
Figure 4.2 Migrant remittances, 2000-2008 (US\$ million; 2008 estimated)

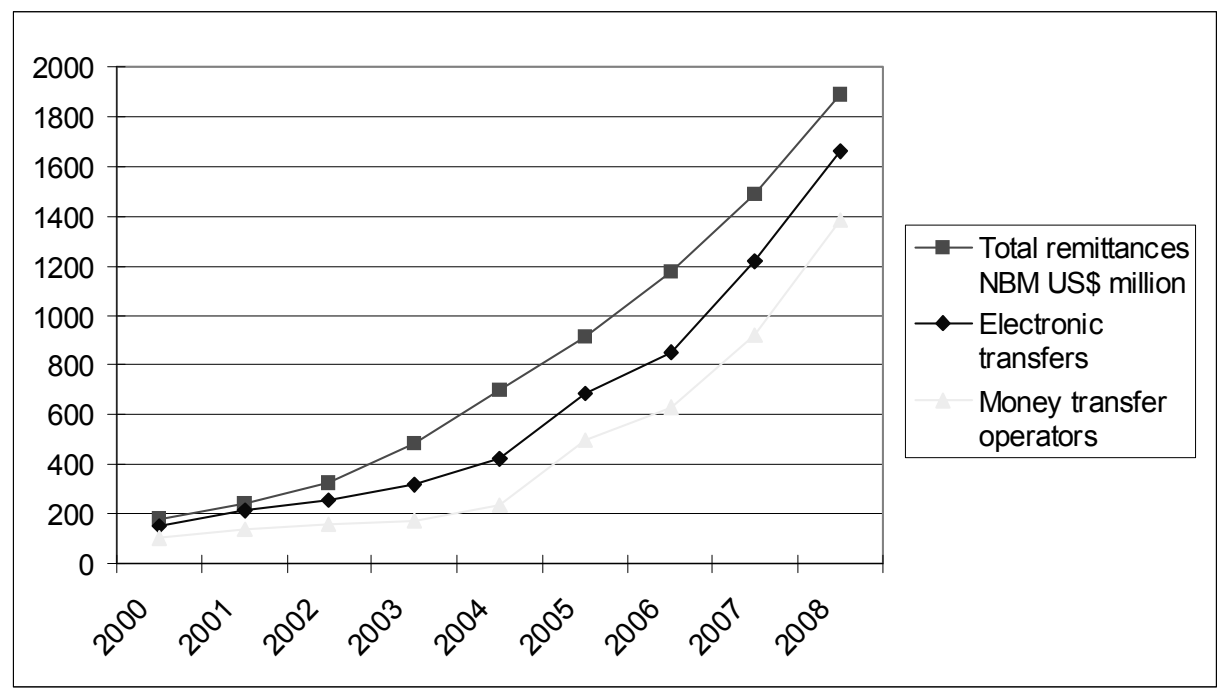

The migration literature distinguishes loosely between push factors (such as worsening living conditions at home) and pull factors (such as a growing awareness of migration opportunities) as possible determinants of the migration decision. In Moldova, mass labour migration was initiated by push factors. Moldova's GDP reached rock bottom in 1999, after a steep decline due to the disintegration of the former Soviet Union in 1991 and the 1992/1993 civil war in Moldova. Several developments came to a head around this time. Externally, the Russian crisis of 1998 caused demand for Moldova's agricultural exports to collapse. Domestically, a run-away government deficit became unsustainable and was eliminated through painful expenditure cuts. Furthermore, collectivised agriculture was finally privatised, leading to job losses at communal farms and a wide-spread return to small-scale and subsistence agriculture.

While most CIS countries registered an output collapse during the 1990s and a gradual recovery from 2000 onwards, structural change was particularly severe in Moldova. Under the Soviet planning system, the Moldovan economy had been heavily specialised in agriculture, enjoying both a protected market for its exports and subsidised energy imports. As a result, the share of agriculture in Moldovan GDP and employment was far higher in the mid-1990s than could possibly be sustained under market economy conditions. When Moldova's terms of trade finally did decline and stop-gap measures by the government were no longer effective, it quickly became clear that Moldovan agriculture could no longer provide gainful employment for a large proportion of the people in rural areas. 
Between 2000 and 2006, the agricultural labour force declined from more than 700,000 individuals to less than 400,000. Conversely, middle-aged men from rural areas with limited educational attainment became a prominent category of migrants during the early 2000s. They are typically employed, often seasonally, by the construction industry in CIS countries which accounted for 34 percent of all Moldovan migrants in 2006 (Luecke, Omar Mahmoud and Pinger 2007: Figure 3.2).

More recently, the profile of migrants has changed to include more women and younger adults. For many of these, pull factors, such as higher incomes and a broader range of employment opportunities abroad, are the primary motivation to migrate. They are also more likely to come from urban areas within Moldova and to plan to live abroad permanently. Apart from CIS countries, where 20 percent of Moldovan migrants were employed in sectors other than the construction industry in 2006, EU countries such as Italy and Portugal (30 percent) and other (relatively) high-income countries such as Turkey and Israel (12 percent) have become important destinations. Migration spells in EU countries tend to be longer than elsewhere because many Moldovan migrants first arrive through irregular channels and seek to stay put in the destination country until their status has been regularised (Luecke, Omar Mahmoud and Pinger, 2007).

Thus, the Moldovan migrant population is highly diverse in terms of socioeconomic characteristics, migration patterns (seasonal vs. long-term), legal status at destination, and access to formal financial services. This makes Moldova an interesting case to study the determinants of transfer channel choice at the household level.

\subsection{Database: the CBSAXA household survey}

The broad trends in migration and remittances since 1999 are captured fairly well by official data sources such as the Labor Force Survey and the balance of payments. However, national policymakers and the donor community have long perceived the need for richer data on the causes and effects of migration and the living conditions of migrants. In response, the Moldova offices of several international organisations (IOM, EU Food Security Program, IMF) commissioned the CBSAXA opinion research firm, in 2004, to conduct a nationally representative household survey that focused on the determinants and the welfare effects of migration and remittances at the household level. Under IOM auspices and with donor funding, the CBSAXA survey was repeated in a comparable format in 2006. In this chapter, we use information on transfer channel choice as well as migrant and household characteristics from the 2006 survey (henceforth: 2006 IOMCBSAXA survey). 
With a total sample size of close to 4,000 households, the survey was designed to be representative of Moldovan households at the national level (excluding the secessionist region of Transnistria), for each major geographic region (North; Center; South; Chisinau), and for each major type of locality (large cities: Chisinau and Balti; other towns; villages). The households to be interviewed were selected according to a systematic sampling scheme (for details, see Luecke, Omar Mahmoud and Pinger, 2007: Box 2.1). Compared with a stratified random sampling scheme, this quasi-random approach has the advantage of being cheaper to implement while generating results that are normally very similar to true random sampling. Due to resource restrictions and practical limitations (for example, poor households often have no telephone), households were selected according to the sampling procedure and interviewed on the spot, without advance information about the interview request. Nevertheless, the overall response rate was very high, with fewer than one in ten selected households not agreeing to be interviewed.

The questionnaire was designed with a view to avoiding sensitive questions as much as possible, for example by asking for qualitative information rather than exact data on income. This concern appears justified: When asked the inevitable question about the amount of remittances, only just over one half of those households that received remittances were willing to indicate an amount (Lücke, Omar Mahmoud and Pinger, 2007). The questionnaire was available in Romanian ("State Language of the Republic of Moldova") and Russian and may be obtained from the authors. 


\subsection{Transfer channel choice, migrant and households characteristics}

This section identifies household-level determinants of transfer channel choice in the existing literature and then presents descriptive information from our dataset on our dependent and explanatory variables. Unfortunately, the existing literature provides only limited guidance regarding the choice of explanatory variables for our regression analysis. Most papers are case studies of particular transfer corridors that informally discuss a wide variety of determinants, including the role of the macroeconomic environment (for example dual exchange rates), political instability, or a weak banking system (for example Buencamino and Gorbunov, 2002). Since our analysis is based on household data for a single country at a single point in time, however, we cannot consider such variables that affect all Moldovan households in the same way. Furthermore, the few existing quantitative studies (including ours) have to contend with the lack of important information in most datasets such as cost estimates for each household for the use of different transfer channels. Instead, proxy variables such as rural vs. urban location are typically used to capture, for example, the relative ease of physical access to banks.

In large descriptive studies of the US-Mexico and Canada-Vietnam remittance corridors, Hernandez-Coss (2005; 2005a) classifies determinants under the headings of personal incentives, customer service incentives, and economic incentives. Personal incentives include anonymity/secrecy, cultural familiarity and personal contacts. For example, the anonymity or secrecy offered by informal services will matter to migrants who fear that formal channels may be connected with law enforcement or immigration authorities in the host country or transmit information to home country tax authorities. Customer service incentives include dispute resolution, accessibility, discrimination and reliability versatility/resilience. Economic incentives include speed, cost, secondary benefits and legal or regulatory environment.

Most other studies come up with less detailed lists of potential determinants. Based on a review of country experiences, Orozco (2003) asserts broadly that, among other factors, access to information, cultural practices, and educational and income status of the recipient and sender influence the choice of transfer method. In an econometric analysis, Amuedo-Dorantes and Pozo (2005) identify the migrant's legal status, sector of employment, family networks in the host country, and length of stay in the host country as important determinants. Not surprisingly, many studies find a strong role for household preferences regarding key attributes of alternative transfer channels such as cost, convenience, speed, security, trust and familiarity (Buencamino and Gorbunov, 2002; Orozco, 2002; El Qorchi, Maimbo et 
al., 2003; Bazenguissa-Ganga, 2005; Freund and Spatafora, 2005; Higazi, 2005; Pieke, Hear et al., 2005) .

Our 2006 IOM-CBSAXA dataset covers 1139 bilateral relationships between a migrant and a recipient household (Table 4.1). Migrants in our sample are either current or former household members. While some households receive remittances from other migrants, these are typically one-off payments linked to life-cycle

Table 4.1: Descriptive statistics for variables in multinomial logit regression

\begin{tabular}{|c|c|c|c|c|}
\hline Variable & $\begin{array}{c}\text { Formal } \\
\text { remittances }\end{array}$ & $\begin{array}{c}\text { Informal } \\
\text { services }\end{array}$ & $\begin{array}{c}\text { Personal } \\
\text { transfers }\end{array}$ & Total \\
\hline Total & 544 & 220 & 375 & 1139 \\
\hline \multicolumn{5}{|l|}{ Education level of migrant (number) } \\
\hline less than secondary compl. & 24 & 8 & 20 & 52 \\
\hline secondary completed & 183 & 70 & 140 & 393 \\
\hline vocational & 218 & 82 & 138 & 438 \\
\hline university & 115 & 50 & 67 & 232 \\
\hline \multicolumn{5}{|l|}{ Socioeconomic characteristics } \\
\hline male migrant (number) & 309 & 83 & 240 & 632 \\
\hline urban household (number) & 164 & 62 & 123 & 349 \\
\hline average hh expenditures (MDL) & 545 & 450 & 510 & 515 \\
\hline migration prevalence at loc. (percent) & 15,2 & 15,9 & 15,2 & 15,3 \\
\hline \multicolumn{5}{|l|}{ Destination country (number) } \\
\hline high income & 204 & 131 & 41 & 376 \\
\hline other non-CIS & 47 & 16 & 47 & 110 \\
\hline CIS & 265 & 61 & 264 & 590 \\
\hline \multicolumn{5}{|l|}{ Migration attributes (number) } \\
\hline Former household member & 146 & 67 & 86 & 299 \\
\hline Legal residence in dest. & 392 & 92 & 244 & 728 \\
\hline Abroad for $<1$ year & 245 & 59 & 237 & 541 \\
\hline \multicolumn{5}{|l|}{ Payment information } \\
\hline household has bank account & 96 & 18 & 28 & 142 \\
\hline remittences sent regularly & 354 & 151 & 157 & 662 \\
\hline \multicolumn{5}{|l|}{ imputed remittances over previous } \\
\hline 12 months (US\$) & 1180 & 1077 & 930 & 1077 \\
\hline \multicolumn{5}{|l|}{ Primary motive in channel choice (number) } \\
\hline cost & 12 & 48 & 35 & 95 \\
\hline speed & 167 & 6 & 7 & 180 \\
\hline convenience & 135 & 77 & 61 & 273 \\
\hline security & 188 & 27 & 131 & 346 \\
\hline trust/ familiarity & 40 & 60 & 132 & 232 \\
\hline
\end{tabular}

Note: figures may not add up to totals because of missing values for some variables.

Source: 2006 IOM-CBSAXA survey; authors' calculations. 
events such as baptisms, weddings, or funerals. Whatever transfer channels are used on such occasions would be of little relevance for the lion's share of remittances that come from current or former household members.

For each bilateral relationship we know the transfer channel that is predominantly used to send remittances. While the IOM-CBSAXA survey identifies approximately ten transfer channels in some detail, we group them into three broad categories:

i. formal services: bank transfer into a Moldovan bank account, money transfer operator (MTO), transfers through the Post office;

ii. informal (third-party) services: train conductor, minibus operator;

iii. personal transfers through migrants themselves, relatives, friends, or acquaintances.

According to the IOM-CBSAXA survey, formal services constitute the primary channel for just under one half of the migrant-recipient pairs (544 out of 1139). In value terms, the share of remittances to Moldova going through formal services is even higher because those migrant-recipient pairs who mainly use formal services report higher remittances (Table 4.1). Imputed remittances over the 12 months before the survey are US\$ 1180 for households that mainly use formal services vs. US\$ 1077 for informal services and US\$ 930 for personal transfers.

Our two remaining categories of transfer channels both relate to informal transfers, rather than the transmission of foreign exchange cash without official registration. In the case of informal services, a third party (such as a train conductor or minibus driver) delivers the payment for a fee. Informal services are the primary transfer channel in one fifth of cases in our sample. Policies that seek to promote formal transfer services will presumably target primarily such informal services provided by third parties.

Our third category is termed "personal delivery" and accounts for the remaining third of cases in our sample. Either migrants themselves, or relatives, friends, close acquaintances etc. deliver cash to the recipient. Obviously, personal delivery only works for those migrants who travel home frequently or have access to a social network that spans their home region and destination country. At the same time, where personal delivery is feasible, it may be difficult to induce migrants and recipients to move to using formal services, given the low cost and convenience of personal delivery.

Our category of formal transfer services could be criticised on the grounds that it lumps together bank transfers and transfers through money transfer operators (MTO). Specifically, it might be argued that a bank transfer, which typically requires the use of bank accounts by both migrant and recipient, implies a higher level of financial sophistication and financial sector development than a transfer 
through an MTO. However, in Moldova, bank and MTO transfers are almost indistinguishable on the ground. Because of licensing requirements, foreign currency transactions are limited to commercial banks; MTOs must offer their services through commercial banks and, conversely, nearly all commercial banks offer the services of more than one MTO (Table 2). In fact, respondents in the IOMCBSAXA survey were often unable to distinguish clearly between bank transfers; this is evident from the fact that many respondents without a bank account claimed that they used bank transfers as their primary transfer channel, which is plainly impossible.

From the point of view of promoting banking services and financial sector development, the Moldovan regulations that require MTO transfers to go through banks may have important advantages. Even without a bank account, recipients are in regular contact with commercial bank staff when they collect payments. For many, this may be a stepping-stone towards using a wider range of banking services, if and when the need arises. Therefore, our broad definition of formal services also makes sense from a policy point of view.

Drawing on the literature on the determinants of transfer channel choice, we identify three broad groups of variables from the CBSAXA dataset that we expect to contribute to an explanation of how migrants and recipients choose between formal services, informal services, and personal delivery:

(i) socioeconomic characteristics of the migrant and other household members;

(ii) the pattern of migration, for example destination country, legal status, duration;

(iii) financial information such as the amount and frequency of payments, financial sophistication as expressed through the use of banking services, preferences for key features of the various channels.

The descriptive statistics for our sample suggest that the choice of transfer channel is strongly correlated with the destination country and the resulting pattern of migration (Table 4.1). Migrants in high-income countries (mostly Italy and other EU member states) are more likely than others to use formal services: 54.3 percent of migrants in high-income countries use this channel (204 out of 376 migrantrecipient pairs), vs. less than 45 percent for the remaining countries. Migrants in high-income countries are also disproportionately frequent users of informal services: 34.8 percent of migrant-recipient pairs (131 out of 376), vs. less than 15 percent for the remaining countries. Migrants in CIS and other non-CIS countries, by contrast, rely much more on personal transfers (more than 40 percent, vs. 10.9 percent in high-income countries). 


Name of bank $\quad \begin{gathered}\text { Balance sheet } \\ \text { (MDL millior } \\ \text { 2006) }\end{gathered} \quad \begin{aligned} & \text { Number of } \\ & \text { locations }^{\mathrm{a}}\end{aligned} \quad$ MTO services offered

\begin{tabular}{|c|c|c|c|}
\hline Agroindbank & 4830 & 91 & $\begin{array}{l}\text { Travelex, Private Money, Anelik, } \\
\text { Western Union }\end{array}$ \\
\hline Banca de Economii & 3470 & 512 & Western Union \\
\hline Victoriabank & 2629 & 16 & $\begin{array}{l}\text { Money Gram, Interexpress, Posta } \\
\text { Rapida, Blizko, MIGOM, Contact }\end{array}$ \\
\hline Mobiasbanca & 1950 & 71 & $\begin{array}{l}\text { Western Union, Swift, Contact, } \\
\text { Anelik }\end{array}$ \\
\hline Moldindconbank & 1800 & 50 & $\begin{array}{l}\text { Western Union, RUS-Express, } \\
\text { Leader-VMT, STRADA ITALIA }\end{array}$ \\
\hline Banka Sociala & 1576 & 23 & $\begin{array}{l}\text { Western Union, Anelik, } \\
\text { Unistream, Posta Rapida, Migom }\end{array}$ \\
\hline Eximbank & 1376 & 50 & $\begin{array}{l}\text { Money4family, Western Union, } \\
\text { Posta Rapida, Privat Money, } \\
\text { Getmoney to family, Xpress } \\
\text { Money, UNISTREAM, Anelik, } \\
\text { Leader, MIGOM, Contact }\end{array}$ \\
\hline FinComBank & 1182 & 31 & $\begin{array}{l}\text { SWIFT, WESTERN UNION, } \\
\text { Anelik }\end{array}$ \\
\hline BC Romana Chisinau & 815 & 2 & Travelex, Anelik, Posta Rapida \\
\hline Investprivatbank & 648 & 32 & $\begin{array}{l}\text { Unistream, Anelik, Posta Rapida, } \\
\text { Western Union, MIGOM }\end{array}$ \\
\hline Energbank & 597 & 57 & $\begin{array}{l}\text { Western Union, Contact, Anelik, } \\
\text { Unistream, Posta Rapida, } \\
\text { Migom, Leader-VMT, } \\
\text { InterExpress }\end{array}$ \\
\hline Unibank & 596 & 19 & $\begin{array}{l}\text { Western Union, Anelik, } \\
\text { Unistream, Migom }\end{array}$ \\
\hline Comertbank & 292 & 1 & Western Union \\
\hline Universalbank & 292 & 7 & $\begin{array}{l}\text { Anelik, Unistream, Money Gram, } \\
\text { Leader, Interexpress, Posta } \\
\text { Rapida, Uno Money Transfer }\end{array}$ \\
\hline EuroCreditBank & 180 & 23 & $\begin{array}{l}\text { Western Union, Anelik, Coinstar, } \\
\text { Contact, UNIStream, Bystraya } \\
\text { Pochta, Migom, Leader, Blizko }\end{array}$ \\
\hline
\end{tabular}

a Branches, representative offices, agencies. 
These findings reflect the prevailing pattern of migration. Migrants in CIS countries are often abroad seasonally; personal transfer is therefore a feasible option for them, and they use it extensively. In fact, of the 541 migrants who staid abroad for less than one year, 237 (or 43.8 percent) use personal transfers. By contrast, migrants in high-income countries often have illegal residence status (EU) and therefore stay away from Moldova for years on end; therefore, they need to send money through third parties rather than carry it home themselves, and they often end up using informal services because of their undocumented status.

These patterns are closely related to the cost of reaching the destination country: in 2006, first-time migrants to the EU paid up to $€ 4,000$ for transport to their destination where they would typically live for several years as undocumented residents; by contrast, travel from Moldova to Moscow (visa-free for Moldovan citizens) could be as cheap as US\$ 100 (Luecke, Omar Mahmoud, Pinger 2007). However, Moldovan migrants in the EU also tend to view their living conditions abroad more favourably than migrants in the CIS; they enjoy higher earnings and send larger remittances.

In the IOM-CBSAXA survey respondents were also asked to indicate the main reason for choosing their primary transfer channel. The answers provide insights into the preferences that underlie the decision-making by migrants and other household members. Of those who use formal services (542 migrant-recipient pairs), 30.8 percent (167 cases) cite speed as their main reason for this choice, vs. less than 3 percent of those using other channels. Users of informal services stress cost advantages (22 percent vs. less than 10 percent of those using other channels) and convenience ( 35.3 percent vs. less than 25 percent). Similarly, personal transfers are chosen especially often for reasons of trust and familiarity. Conversely, relatively few migrant-recipient pairs choose formal services because of their cost or familiarity, or informal services because of speed or security, or personal transfers because of speed or convenience.

While this descriptive information is suggestive, it does not allow us to identify systematically the impact of each potential determinant on the choice of the transfer channel. In the following section, we use a multinomial logit regression model to conduct a more thorough analysis.

\subsection{Econometric model}

The purpose of our econometric analysis is to explain the choice of transfer channel (formal services or informal services or personal transfers) on the basis of migrant and household characteristics. Thus, our dependent variable (the chosen transfer channel) is categorical and standard regression techniques are not applicable. 
Furthermore, we are dealing with a nominal dependent variable because our categories follow no natural order (as opposed to, say, size classes for a particular product which run from smallest to largest). As discussed in the preceding section, our potential explanatory variables are all case-specific, rather than for each migrant-recipient pair, the variables take the same value for all three possible choices. For example, we know the migrant's level of education and can assess its impact on the choice of transfer channel. However, we do not know the cost that the particular migrant-recipient pair would incur using each of the three channels, which will often differ across households. Thus we have no alternative-specific data for each case, but only case- (migrant-recipient-pair) specific data.

The appropriate regression model under these circumstances is the multinomial logit or probit model. Formally (Amuedo-Dorantes, Pozo 2005; Long and Freese 2006), the model may be described starting from the notion that a migrant-recipient pair $(i=1 \ldots . n)$ derives utility $U_{i j}$ from using a given transfer channel $j(j=1$ for formal services, $j=2$ for informal services, $j=3$ for personal transfers). $U_{i j}$ depends deterministically on a set of explanatory variables $X_{i}$ and coefficients $\beta_{j}$ as well as on a random component:

$$
U_{i j}=V_{i j}+\varepsilon_{i j}=\beta_{j}^{\prime} X_{i}+\varepsilon_{i j},
$$

where $V_{i j}$ is the deterministic and $\varepsilon_{i j}$ the random component of the utility function.

The probability of migrant $i$ choosing transfer channel $j$ is equal to the probability of $U_{i j}$ being the largest among $U_{i 1}, \ldots U_{i 3}$. Hence

$$
P_{i j}=\operatorname{Prob}\left(Y_{i}=j\right)=\operatorname{Prob}\left(U_{i j}>U_{i k}\right)=\operatorname{Prob}\left(\varepsilon_{i j}-\varepsilon_{i k} \leq \beta_{j}{ }^{\prime} X_{i}-\beta_{k}{ }^{\prime} X_{i}\right),
$$

where $k=1 \ldots 3$ and $k \neq j$.

The specific form of the model depends on the distribution of the error terms. If we assume that the error terms are distributed according to a Type I extreme value distribution and are independent across alternatives $j$, the multinomial logit model results. For normally distributed error terms, which may be correlated across alternatives, the multinomial probit model is obtained. In our analysis, we use the multinomial logit model because (i) the multinomial probit model is computationally burdensome and the estimates are typically very similar to the multinomial logit model (Long and Freese, 2006: 276) and (ii) we find that the 
assumption of uncorrelated error terms across alternatives (also known as IIA: independence of irrelevant alternatives; see below) is not rejected by our data. ${ }^{1}$ When the multinomial logit model is estimated, one alternative needs to be chosen as the base outcome and coefficient estimates are calculated in relation to that base outcome (for a detailed discussion, see Long and Freese, 2006: 228). However, the choice of the base outcome affects only the parameterisation of the model, not the predicted probability of migrant-recipient pair $i$ choosing channel $j$ :

$$
P_{i j}=\operatorname{Pr} o b\left(Y_{i}=j\right)=\frac{\exp \left(\beta_{j}^{\prime} x_{i}\right)}{\sum_{k=1}^{3} \exp \left(\beta_{k}^{\prime} x_{i}\right)} .
$$

In our analysis, we choose formal services as the base outcome because we are particularly interested in finding out what renders individuals more likely to choose transfer channels other than formal services. Formal services are arguably the most desirable from the point of view of fostering financial development. Once we understand why some individuals do not use them, we can consider the benefits and costs of possible policy interventions to strengthen incentives to use formal services.

As the coefficients from multinomial logit regressions are difficult to interpret, we present our regressions results in the form of relative risk ratios between for unit changes in each explanatory variable:

$$
\frac{P_{i j}}{P_{i k}}=\exp \left(\beta_{j}^{\prime} x_{i}\right),
$$

where $j=k$ is the base outcome (formal services in our case). For example, a relative risk ratio of 0.5 for the male migrant dummy variable $($ male $=1$, female $=0$ ) and informal services implies the following (cf. Table 3 below): if the migrant is male rather than female, this reduces the ratio of the probabilities that informal services vs. formal services (base outcome) are used by one half.

As noted above, the multinomial logit model assumes independence of irrelevant alternatives (also known as the red bus/ blue bus problem; cf. Long and Freese, 2006: 243). This assumption implies that adding or deleting alternatives does not affect the odds among the remaining alternatives. For example, the odds of using formal vs. informal services are assumed to be the same independent of whether there exists a third option, rather than personal transfers. This is equivalent to stating that if personal transfers were (hypothetically) eliminated, those individuals who previously used personal transfers would use formal and informal services in the same proportion as all other migrant-recipient pairs in the 
sample. This assumption may be plausible if the alternatives are defined to be sufficiently different in the views of the decision-makers. In our hypothetical example, the use of personal transfers is feasible if a migrant either travels to Moldova often enough or has access to a network of other migrants from the same region in Moldova. Now if personal transfers were somehow eliminated, there is no strong reason why those who previously used them would shift overwhelmingly to either formal or informal transfers; they might well make this choice in similar proportions as the rest of the population.

For the IIA assumption to hold, it has to be possible to eliminate (hypothetically) any one option without affecting the odds between the remaining alternatives. Accordingly, the validity of the IIA assumption for a given dataset and definition of alternatives can be assessed through a Hausman specification test in which one alternative is dropped at a time and the results of each such restricted model are compared to the full model (Table 4.3 below). Long and Freese (2006: 244) discuss several implementation issues with the Hausman test and a similar Small-Hsiao test; in our analysis, we use a robust procedure recently implemented under the Stata "suest" command that takes care of these issues. The test statistics confirm that we can safely assume IIA for our model (bottom of Table 4.3). 
Table 4.3 Regression results (multinomial logit): Transfer channel choice

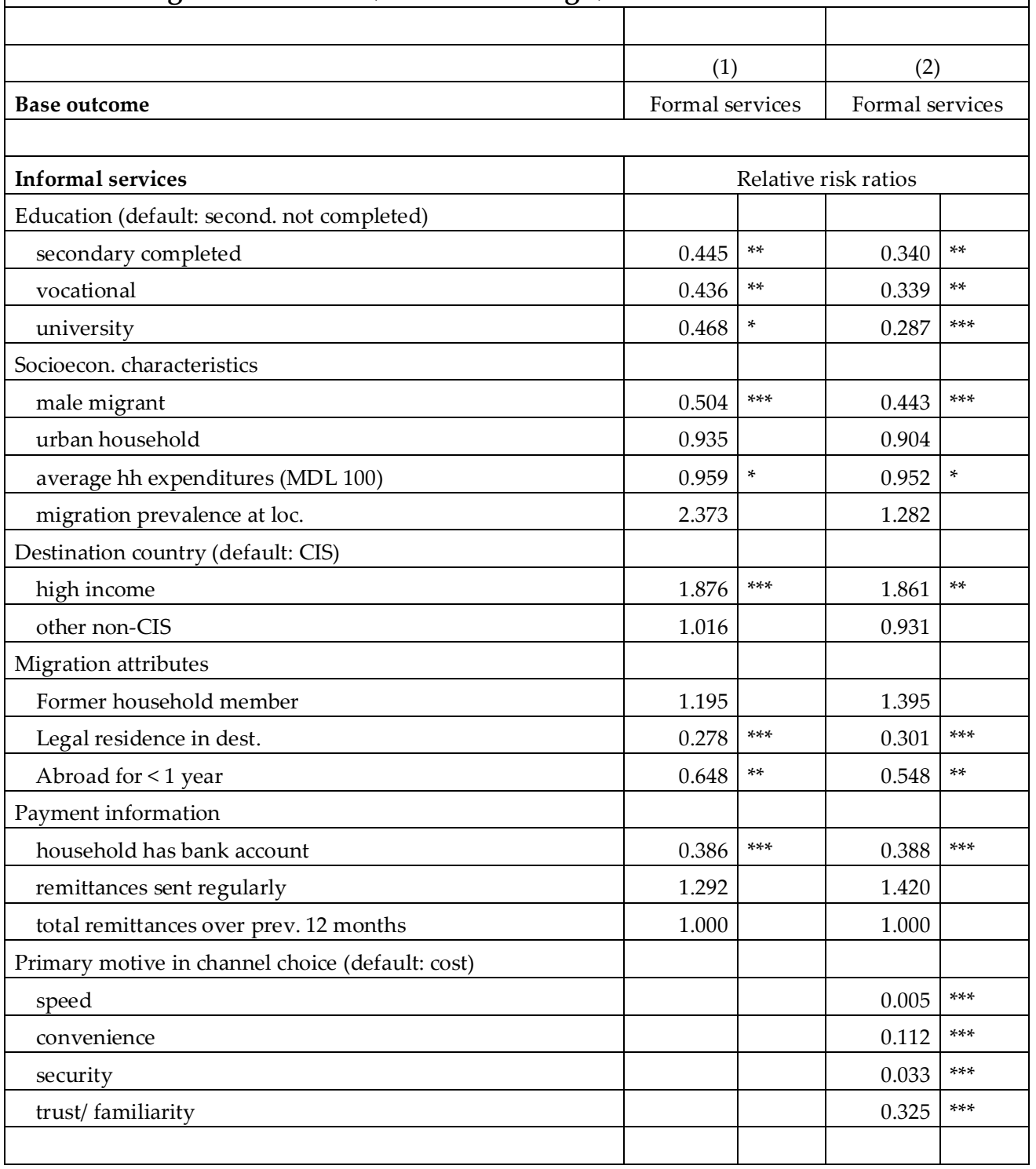




\begin{tabular}{|c|c|c|c|c|c|c|}
\hline \multirow[b]{2}{*}{ Personal transfers } & \multicolumn{3}{|c|}{$(1)$} & \multicolumn{3}{|c|}{$(2)$} \\
\hline & \multicolumn{6}{|c|}{ Relative risk ratios } \\
\hline \multicolumn{7}{|l|}{ Education (default: second. not completed) } \\
\hline secondary completed & & 0.592 & & & 0.396 & $* *$ \\
\hline vocational & & 0.606 & & & 0.403 & $* *$ \\
\hline university & & 0.693 & & & 0.386 & ** \\
\hline \multicolumn{7}{|l|}{ Socioecon. characteristics } \\
\hline male migrant & & 0.990 & & & 0.884 & \\
\hline urban household & & 1.104 & & & 1.041 & \\
\hline average hh expenditures (MDL 100) & & 1.011 & & & 1.013 & \\
\hline migration prevalence at loc. & & 0.264 & & & 0.099 & * \\
\hline \multicolumn{7}{|l|}{ Destination country (default: CIS) } \\
\hline high income & & 0.238 & $* * *$ & & 0.271 & $* * *$ \\
\hline other non-CIS & & 0.890 & & & 1.003 & \\
\hline \multicolumn{7}{|l|}{ Migration attributes } \\
\hline Former household member & & 0.736 & & & 0.753 & \\
\hline Legal residence in dest. & & 0.692 & $* *$ & & 0.878 & \\
\hline Abroad for $<1$ year & & 1.683 & $* * *$ & & 1.557 & $* *$ \\
\hline \multicolumn{7}{|l|}{ Payment information } \\
\hline household has bank account & & 0.693 & & & 0.625 & \\
\hline remittences sent regularly & & 0.310 & $* * *$ & & 0.310 & $* * *$ \\
\hline total remittances over prev. 12 months & & 1.000 & & & 1.000 & \\
\hline \multicolumn{7}{|c|}{ Primary motive in channel choice (default: cost) } \\
\hline speed & & & & & 0.015 & $* * *$ \\
\hline convenience & & & & & 0.131 & $* * *$ \\
\hline security & & & & & 0.200 & $* * *$ \\
\hline trust/ familiarity & & & & & 0.956 & \\
\hline Number of observations & & 1034 & & & 1034 & \\
\hline Pseudo R² & & 0.161 & & & 0.307 & \\
\hline \multicolumn{7}{|l|}{ Hausman test of IIA assumption (Ho) } \\
\hline \multicolumn{7}{|c|}{ based on SUR model (STATA command: suest) } \\
\hline Degrees of freedom & 16 & & & 20 & & \\
\hline Omitted alternative & $\mathrm{Chi}^{2}$ & $\mathrm{P}>\mathrm{Chi}^{2}$ & Evidence & & $\mathrm{P}>\mathrm{Chi}^{2}$ & Evidence \\
\hline Formal services & 14.4 & 0.566 & for Ho & 25.9 & 0.170 & for Ho \\
\hline Informal services & 16.4 & 0.425 & for Ho & 24.2 & 0.236 & for Ho \\
\hline Personal transfers & 16.7 & 0.403 & for Ho & 25.8 & 0.173 & for Ho \\
\hline Legend: ${ }^{*} p<.1 ;{ }^{* *} p<.05 ;{ }^{* * *} p<.01$ & & & & & & \\
\hline
\end{tabular}




\subsection{Multinomial regression model}

Our multinomial regression model explains the choice of transfer channel (formal services, informal services, personal transfers) through the independent variables described in Section 4 (Table 4.3). Our first specification (1) uses all explanatory variables introduced in Section 4, except the primary motive for choosing the transfer channel; our second specification (2) adds the dummy variables that describe the primary motive. We report relative risk ratios (as explained in Section 5 above) along with the significance levels of the associated coefficients.

We consider the impact of the "primary motive" variables separately to account for a possible ambiguity in the phrasing of the corresponding survey question. The survey asks "What do you think has been the main reason for (...) to use this channel?" with the answer options given in Table 2. We take the response to indicate the primary motive that has guided the decision on the transfer channel. However, from the phrasing of the question, we cannot exclude the possibility that some respondents in fact indicated what they saw as the main advantage of the chosen channel.

A comparison of specifications (1) and (2) shows that adding the "primary motive" variables adds considerably to the explanatory power of the model, with the Pseudo $\mathrm{R}^{2}$ going from 0.161 to 0.307 . Relative risk ratios for informal services and the "primary motive" dummies such as speed, convenience, etc. are all significantly below 1 . To interpret these relative risk ratios, recall that the default for the "primary motive" dummy variables is cost. For example, a unit increase in the "speed" dummy variable (to which the relative risk ratio refers) implies that speed, rather than cost, is now the primary motive. Given the relative risk ratio (rrr) of 0.005 , the likelihood that informal services are chosen, relative to the likelihood that formal services are chosen, is now only 0.5 percent of its former level when cost was the primary motive.

Less formally speaking, in choosing between informal services and formal services (our base outcome), migrants and their families are more likely to opt for informal services if they are primarily concerned about cost, rather than speed, convenience, security or trust/ familiarity. Similarly, in choosing between personal transfers and formal services (second part of Table 4.3), they are more likely to opt for personal transfers if they are primarily concerned about cost, rather than speed, convenience or security (rrr below 0.2 ). If they are primarily concerned about trust/ familiarity rather than cost, this does not affect the relative probabilities of choosing personal transfers vs. formal services (rrr close to 1 ). 
Overall then, of the possible primary motives for choosing the transfer channel, only concern about the cost of transfers will draw migrants and their families away from formal services towards either informal services or personal transfers. A preference for speed, convenience, and security will all draw migrants and their families towards using formal services. If they are primarily concerned about trust/familiarity, this will draw them away from informal towards formal services, but will not affect their decision as between personal transfers and formal services. In assessing possible policy conclusions from these findings (see Section 7 below), we will take into account that of 1126 migrant-recipient pairs with data on "primary motive", only 95 were primarily concerned about cost (Table 4.1).

A comparison of Specifications (1) and (2) shows that that the relative risk ratios for the remaining explanatory variables are fairly robust to the inclusion of the "primary motive" variables. Although some magnitudes and significance levels change, the broad picture does not. Turning to the role of education first, if the migrant has at least completed secondary school (which some rural migrants have not), informal services and personal transfers are less likely to be used (rrr below 0.5 for informal services and equal to 0.4 and lower for personal transfers under Specification 2). Apparently the least educated migrants are reluctant to use formal financial institutions, which appears plausible. At the same time, this effect is limited to migrants who have not completed secondary school; among those who have at least completed secondary school, there is no effect of a higher education level on transfer channel choice (the rrr are almost the same for completed secondary school, vocational and university education). Also, since only 52 out of 1115 migrants in the sample had not completed secondary school, this effect is limited to a small group of mostly old, rural migrants.

Regarding other socioeconomic characteristics of the migrant and the household, only a few relative risk ratios reflect statistically significant coefficients. In particular, male migrants are only half as likely as female migrants to use informal services relative to formal services (rrr close to 0.5 ), with no such effect for personal transfers relative to formal services. It is difficult to see how gender as such could have such a large impact on transfer channel choice. As gender is correlated with other explanatory variables, particularly the pattern of migration, there may be collinearity among explanatory variables which causes the seeming gender effect. Specifically, informal services are widely used in the EU where the share of women among Moldovan migrants is higher than in the CIS. In part, this probably reflects the illegal residence status of many Moldovan migrants in the EU. Furthermore, the cost of formal transfer services tends to be higher in the EU than in the CIS where competition among money transfer operators serving Moldovan (and other) migrants has intensified in recent years and fees have been cut. Many of the MTOs listed in Table 4.2 are active mostly in CIS countries. 
As expected, being a migrant in a high-income country (typically the EU) rather than in the CIS almost doubles the likelihood of using informal services, relative to formal services (rrr around 1.9). By contrast, the likelihood of using personal transfers, relative to formal services, is reduced by more than two thirds (rrr below 0.3). The very limited use of personal transfers, which is also apparent from Table 1 , probably reflects (i) the lower density of Moldovan migrants in the destination cities (compared to, say Moscow) and the consequent absence of networks of friends and relatives from the same region in Moldova; and (ii) the need for migrants, especially with illegal residence status, to stay in the host country for long periods without being able to return.

Also as expected, legal residence in the destination country (rather than illegal residence) reduces by about two thirds the likelihood of using informal services relative to formal services (rrr equal to 0.3 or lower). At the same time, legal residence status has no strong effect on the use of personal transfers relative to formal services.

Those who are abroad for less than one year, often as seasonal workers, are less likely than those who are abroad for longer periods to use informal services, relative to formal services (rrr equals 0.65 or less). At the same time, they are more likely to use personal transfers, relative to formal services, presumably because many will be able to carry remittances back home themselves (rrr equals 1.6 or higher).

Thus the explanatory variables that are related to the migration pattern show plausible and expected effects that coincide in large measure with the genderbased travel and work patterns. This may explain the large gender effect on the use of informal vs. formal services.

Among the finance-related explanatory variables, households with (rather than without) a bank account are much less likely to use informal relative to formal channels (rrr below 0.4). This variable raises a possible simultaneity problem because households may open a bank account precisely to use formal transfer services. However, we have not been able to find good instrumental variables that would enable us to deal with this issue formally. Those who send money regularly (at least four times per year) are two thirds less likely to use personal transfers (rrr equals 0.3). 


\subsection{Policy implications}

Our regression analysis has identified several important reasons why approximately one half of the Moldovan migrants and their families in our sample do not use formal transfer channels. Migrants who mostly use informal services are more likely to be in high-income countries (mostly the EU), reside in the host country illegally, remain abroad for periods longer than one year, not have a bank account, and care primarily about the cost of the transfer (rather than speed, convenience, security, or familiarity). Migrants who rely mostly on personal transfers are more likely to be in CIS countries, remain abroad for less than one year, not send remittances regularly, and care primarily about the cost of the transfer (rather than speed, convenience, or security).

Some of these determinants suggest the presence of distortions that can potentially be reduced through appropriate policy measures. Other determinants reflect migration patterns such as seasonal or irregular migration that will probably cause some migrants to use personal transfers or informal services irrespective of the wider institutional and policy environment. The main starting points for policy interventions are the cost of money transfers, the treatment of irregular migrants in host countries, and the linkage between remittances and financial sector development.

Although the fees for international money transfers have declined substantially in recent years, transfer costs continue to play a large role in the choice of the transfer channel. According to Sander et al. (2005), fees paid by Moldovan migrants varied widely between 1 percent and 20 percent of the amount sent, with substantially lower fees for informal channels in many cases. As fees often include a fixed pertransaction component, smaller amounts incur a relatively higher fee. The IOMCBSAXA survey includes only limited information that refers to the fees actually paid for the selected transfer channel, rather than for a wider range of options that might be available to the particular migrant-recipient pair.

The recently established World Bank database "Remittance Prices Worldwide" lists mid-2008 fees including exchange rate premiums for many remittance corridors, including Russia to Moldova but no other flows to Moldova. ${ }^{2}$ However, fees for transfers from Italy and elsewhere in Western Europe to Eastern Europe are probably broadly representative of the options available to Moldovan migrants. Typically, transfer fees from Western Europe are much higher than from Russia to Moldova ( 5 to 15 percent vs. 1.5 to 5 percent). This observation probably explains why informal channels are used widely from high-income countries to Moldova but not from CIS countries. 
Furthermore, across corridors originating in Western Europe, the fee level seems to be lower if specialised service providers (say, those active only in a particular region) compete with the established market leaders (Western Union and MoneyGram). Competition appears to be even more lively in the market for transfers from Russia. Even though information in the World Bank database is not fully representative, the fee differences across providers within particular corridors as well as across corridors with (presumably) similar cost structures are astonishing. These observations suggest that by fostering competition in high-cost locations, transfer fees could be brought down and the recipients' welfare gains from remittances enhanced. Recent initiatives in several remittance sending countries to increase the transparency of fee structures and enhance competition are therefore highly appropriate.

Within Moldova, the large number of active money transfer operators (MTOs) suggests that there is a fair degree of competition in the market for international transfers which has helped to bring down transfer fees (cf. Table 2). MTOs are obliged to operate through commercial banks. While this rule makes it easier to offer other banking services to recipients of remittances and may thereby facilitate financial sector development, there is an inherent risk that it may limit competition in the market for international transfers.

That risk is enhanced by the fact that the one commercial bank that controls more than half the banking presence in the country (branches, representative offices, agencies) cooperates only with a single $\mathrm{MTO}$, in contrast to most other commercial banks. Presumably the restrictions on the independent conduct of international transactions by non-bank entities such as MTOs or even credit unions reflect a desire for tight prudential control in a country where financial markets are not yet mature and the legal order is only emerging. However, the desire for close oversight should be balanced against the need, on welfare grounds, to enhance competition in the oligopolistic commercial banking sector and in the market for international transfers in particular.

Our regression analysis shows that irregular residence status makes it less likely that migrants will use formal transfer channels. While it is now an established principle that financial institutions have to "know their customers", it is not clear that this should prevent them from serving irregular immigrants whose presence is nevertheless tolerated by host country authorities, to the point where many such immigrants may qualify for legal residence after a few years in the host country. Regulations that allow irregular immigrants to identify themselves using home country documents without fear of deportation might attract migrants away from informal transfer services which are, by their very nature, less transparent than formal channels. 
Regarding the linkage between remittances and financial development, Rios Avila and Schlarb (2008) show through an econometric analysis based on the 2006 IOMCBSAXA survey that remittances provide an incentive to use more banking services; in particular, households with migrants are significantly more likely to own a bank account. At the same time, the share of "banked" households at 11 percent of all households is much lower than the share of households that receive remittances. As remittances will often not be spent immediately and many migrant households have considerable amounts of savings, there would appear to be room for households to be offered more financial services, starting with current and savings accounts. The fact that money transfer operators in Moldova have to work exclusively through commercial banks should make it easier for banks to reach migrants and their families. As recipients come to pick up their remittances, they become more familiar with their bank and are exposed to the marketing of banking services. While internationally comparable data are scarce, the limited information available (Claessens, 2006) suggests that in many developing and transition countries, the share of households using formal financial institutions is similarly low.

While more can and should be done to promote formal transfer services for remittances, both in remittance-sending countries and in Moldova, the fact that just under half of all migrant-recipient pairs use formal channels represents an important achievement. In value terms, the market share of formal services is probably even higher because higher payments are more likely to go through formal channels (which is not fully reflected in the dataset because higher remittances in particular are under-reported). The wide-spread use of formal transfer services is mirrored by the financial deepening that has occurred in Moldova since 1999 (Figure 3). Although most Moldovans had their savings wiped out in the aftermath of the dissolution of the Soviet Union and the level of financial literacy remains low, confidence in banks is returning and the ratio of bank account balances to GDP has quadrupled from 1999 to 2008, with especially strong increases for individual (rather than business) accounts. 
Figure 4.3 Average balance on bank accounts, by type, 1999-2008 (per cent of GDP)

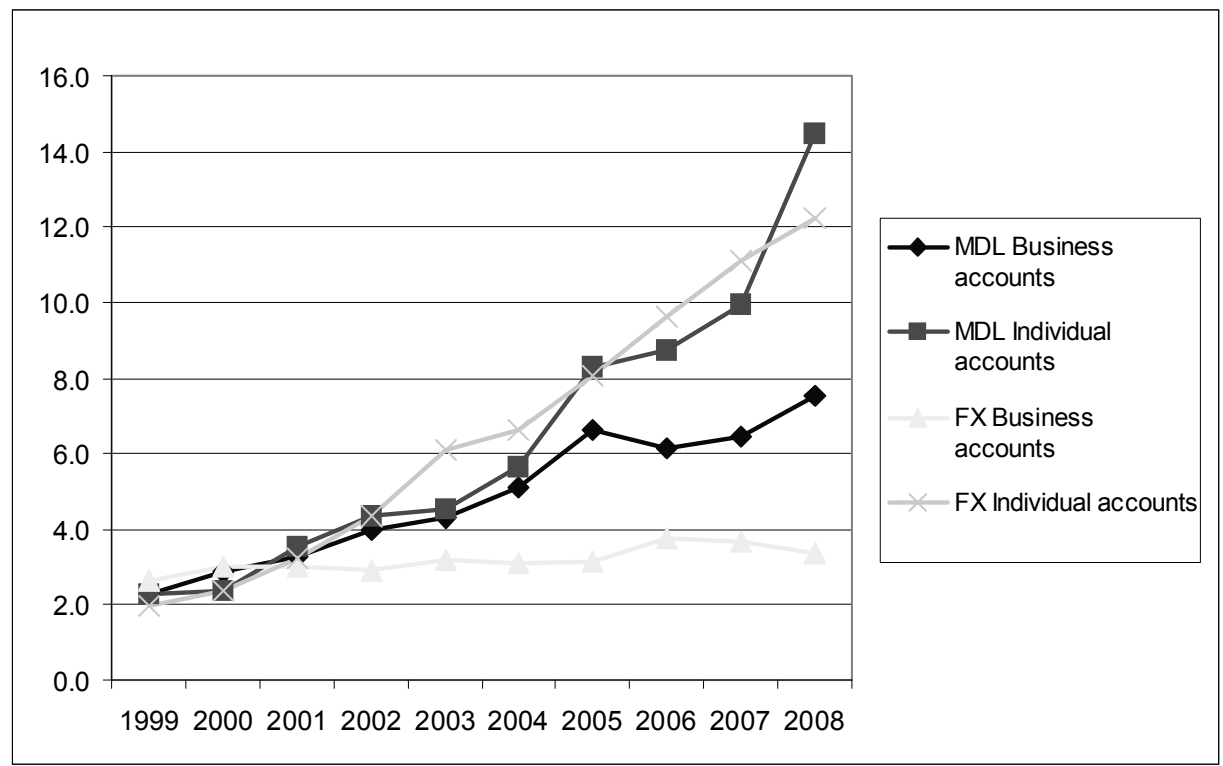

Source: $\quad$ National Bank of Moldova; National Bureau of Statistics; authors' calculations. 


\subsection{References}

Amuedo-Dorantes, C. (2005). "On the Use of Differing Money Transmission Methods by Mexican Immigrants." International Migration Review 39(3): 554-576.

Bazenguissa-Ganga, R. (2005). Democratic Republic of Congo (Congo-DRC) and Republic of Congo (Congo) Country Study: A part of the report on Informal Remittance Systems in Africa, Caribbean and Pacific (ACP) C. o. M. P. a. S. (COMPAS), University of Oxford

Buencamino, L. and S. Gorbunov (2002). "Informal Money Transfer Systems: Opportunities and Challenges for Development Finance." Discussion paper of the United Nations Department of Economic and Social Affairs 26.

Chami, R., A. Barajas, et al. (2008). "Macroeconomic Consequences of Remittances." International Monetary Fund Occasional Paper 259.

Claessens, S. (2006). "Access to Financial Services: A Review of the Issues and Public Policy Objectives." World Bank Research Observer 21: 207-240.

El-Qorchi, M., S. M. Maimbo, et al. (2003). Informal Funds Transfer Systems: An Analysis of the Informal Hawala System. T. I. M. F. a. T. W. Bank. Washington, D.C.

Freund, C. and N. Spatafora (2005). "Remittances: Transaction Costs, Determinants, and Informal Flows." World Bank Policy Research Working Paper 3704.

Hernández-Coss, R. (2005). "The Canada-Vietnam Remittance Corridor: Lessons on Shifting from Informal to Formal Transfer Systems." World Bank Working Paper 48.

Hernández-Coss, R. (2005). "The U.S.-Mexico Remittance Corridor: Lessons on Shifting from Informal to Formal Transfer Systems." World Bank Working Paper 47.

Higazi, A. (2005). Ghana Country Study: A part of the report on Informal Remittance Systems in Africa, Caribbean and Pacific (ACP) C. o. M. P. a. S. (COMPAS), University of Oxford.

Long, J. S. and J. Freese (2006). Regression Models for Categorical Dependent Variables Using Stata. 2nd edition. College Station, Texas, Stata Press.

Lücke, M., T. O. Mahamoud, et al. (2007). Patterns and Trends of Migration and Remittances in Moldova. Chisinau, International Organization for Migration.

OECD (2007). Policy Coherence for Development. Paris.

Orozco, M. (2002). Remittances and Markets: New Players and Practices. Sending Money Home: Hispanic Remittances and Community Development. R. O. d. 1. Garza and B. L. Lowell, Rowman and Littlefield Publishers. 
Orozco, M. (2003). "Worker Remittances: A International Comparison." Working Paper of the Multilateral Investment Fund of the Inter-American Development Bank.

Pieke, F. N., N. V. Hear, et al. (2005). Synthesis Study: A part of the report on Informal Remittance Systems in Africa, Caribbean and Pacific (ACP) countries C. o. M. P. a. S. (COMPAS), University of Oxford.

Rios-Avila, F. and E. Schlarb (2008). "Bank Account and Savings - The Impact of Remittances and Migration: A Case Study of Moldova." Kiel Advanced Studies Working Paper 448.

Sander, C., D. Nistor, et al. (2005). Migrant Remittances and the Financial Market in Moldova. BASIS CRSP, Madison: University of Wisconsin

Spatafora, N. (2005). Two Current Issues Facing Developing Countries. World Economics Outlook. Washington, D.C., IMF. 


\section{Chapter 5: Immigrant Integration and Remittance Channel Choice}

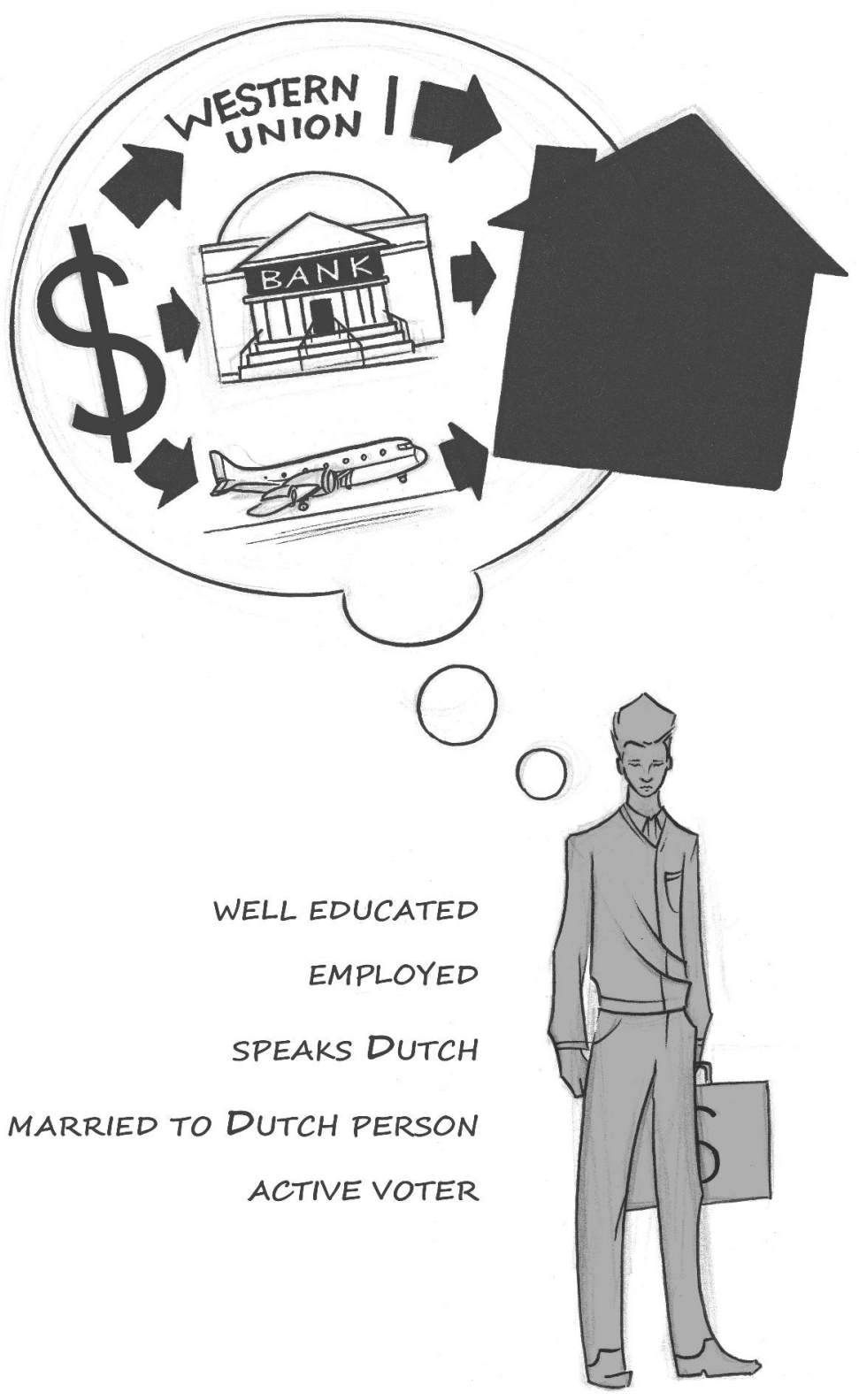




\subsection{Introduction ${ }^{47}$}

This chapter empirically assesses the effect of immigrant integration on the channel chosen to send remittances, migrant money transfers, between countries. In recent years, the World Bank, the IMF and international policy makers have pushed to formalize remittances. Formalization would require a shift from sending remittances informally, via cash couriers, underground banking and postal delivery to sending money transfers formally through banks and regulated money transfer operators such as Western Union. There are two main arguments in favor of the formalization: 1) increased transparency in money transfers which helps counter money laundering and terrorist financing, and 2) favorable developmental effects of remittances moving through formal institutions, in terms of increased capital and guaranteed secured funds for borrowing at the macro level (World Bank, 2005). There is a greater multiplier effect of remittances when they are transferred through banks since the money can be used to finance other productive investments. Banks can also use remittance transfers as a way to "bank the unbanked" by coupling other financial services with remittance transfers. It is reasonable to assume that immigrants who are more integrated in their host society are more comfortable and familiar with the host society's institutions, including banks and money transfer operators. It is also possible that integrated migrants feel more empowered to utilize formal financial agencies for services they need, including the transferring of funds internationally. Finally, integrated migrants may have better access to social capital including linguistic skills, transportation, and cultural competency, which may facilitate the use of formal channels for remittances and particularly banks. Because the formalization of remittances is increasingly important in international policy, it is important to understand the effect immigrant integration can have on remittance channel choice. Such understanding could inform economic policy with respect to migrant populations.

There is a new emerging area of literature in cultural economics. Recent studies have examined the impact of culture on development (Tabellini, 2006), trade (Guiso, Sapienza, \& Zingales, 2006), growth (Barro \& McCleary, 2003; McCleary \&

\footnotetext{
${ }^{47}$ This chapter is based on the Maastricht Graduate School of Governance working paper MGSoG Working paper 2007/09. I would like to thank The Fourth Challenge Training School on Integration, Immigration and Citizenship, Center for European Policy Studies, Brussels, Belgium, November, 2007; Harvard University, Migration and Immigrant Incorporation Workshop, 2008; IMISOE PhD Summer Workshop, Lisbon, Portugal, 2008; International conference on immigration, consumption and markets, Lille, France, May, 2009 and Hein de Haas and Stephanie Wheeler for their helpful comments on an earlier draft of this paper.
} 
Barro, 2006), living arrangements (Giuliano, 2007), fertility and female labor force participation (Fernández \& Fogli, 2005), firms and employment (Bertrand \& Schoar, 2006) and economic behavior and attitudes (Alesina \& Giuliano, 2007). This chapter contributes to the existing literature by examining the relationship between culture (immigrant origin) and remittance channel choice, a topic which has been left unexplored in the literature thus far.

The term integration may be interpreted in different ways, but for the purpose of this chapter, the term is used as the degree to which immigrants become part of Dutch society. Favell (2005) describes integration as: " a 'middle way' between coercive conformism to national norms and values, on the one hand, and the threat of separatism, seen as latent in the excessive preservation of non-European cultures, on the other." This chapter looks at both socio-economic integration (usually measured by structural aspects including labor market position and education level) and socio-cultural aspects of integration. Socio-economic measures of integration usually include structural aspects of integration, such as labor market participation and education level. Not surprisingly, it is more difficult to measure variables which affect sociocultural integration than those related to socio-economic integration, although, empirical research has shown that they are strongly correlated (Snel, Engbersen, \& Leerkes, 2006).

In this chapter, integration is considered at two different levels: the individual level and the immigrant group level. It is important to test both the individual and group level integration to determine which factors are most important with respect to remittance channel choice and to be able to draw conclusions at both levels. At the individual level, this chapter hypothesizes that the more integrated an individual is, the more likely that person will be to remit formally, and particularly through banks. The specific variables used as a proxy for individual integration are (1) whether or not the person was born in the Netherlands (assuming that those born in the country will be more integrated because of growing up in the society), (2) length of time the person has lived in the Netherlands (assuming that the longer the person has lived in the Netherlands, the more integrated they will be) and (3) the individual level of education (assuming the greater the education, the more integrated ${ }^{48}$ ). Tubergen, Maas, et al. (2004) found that education, work experience, language skills, age at time of migration and length of stay in the host country are important factors affecting economic (socio-economic) integration. Additionally, migrants who move at a young age (or were born in the country), who have been living in the host country for many years, those with higher education, more work experience and better language skills usually attain a better economic position in the host society.

\footnotetext{
${ }^{48}$ Age at migration would be another useful variable to look at which is not in the data set.
} 
Moving from individual integration to group level integration, this chapter hypothesizes that the more integrated the immigrant group as a whole, the more likely members of the group will be to use formal channels, and specifically banks due to familiarity with the host country and its infrastructure. Tubergen, Maas, \& Flap (2004) found that even after taking into account individual characteristics, immigrants' economic position differs among origin groups in the host country. Evidence from the United States (Borjas, 1999) also shows that migrants' origin matters for economic integration. Many other authors have also found that migrant origin matters for integration outcomes (Amuedo-Dorantes, 2007; Bevelander \& Nielsen, 2001; Borjas, 1985, 1995; Hartog \& Winkelmann, 2003; Longva \& Raaum, 2002; Schmidt, 1997; Schoeni, 1998; Wheatly, 1999). To measure integration empirically, this chapter first examines the many potential factors influencing immigrant integration and then develops a ranking of group integration in the Netherlands. The chapter then goes on to statistically test which remittance channels the different migrant groups are using and conclusions are drawn based on the integration of the group and other characteristics.

Section 2 gives more insight into the Dutch reality of immigration and remittances, as well as a more focused look at the immigrant groups studied in the analysis. Section 3 discusses the construction of the index of immigrant integration in the Netherlands. Section 4 gives some descriptive statistics and explains the remittance channels used by different groups. Section 5 empirically tests the remittance channel decision between formal and informal transfers and the decision between money transfer operators and banks using probit models. Section 6 gives concluding remarks.

\subsection{Immigration and remittances in the Netherlands}

The Netherland is a clear immigration country. The current stock of immigrants in the Netherlands is 1.6 million, which makes up $10 \%$ of the population (Ratha \& $\mathrm{Xu}$, 2008). Persons with a foreign background (including first and second generation immigrants) constitute $19 \%$ of the population (CBS Statline, 2005). Figure 5.1 shows the total population of people residing the Netherlands who have foreign nationality. The number of foreign nationals has risen considerable in the lat 50 years, although the largest increase was from the 1970s to the 1990s. The number of foreign nationals is lower than the previously stated immigrant stock since many immigrants gain Dutch nationality and are, therefore, not considered foreign nationals any longer. 
Figure 5.1:

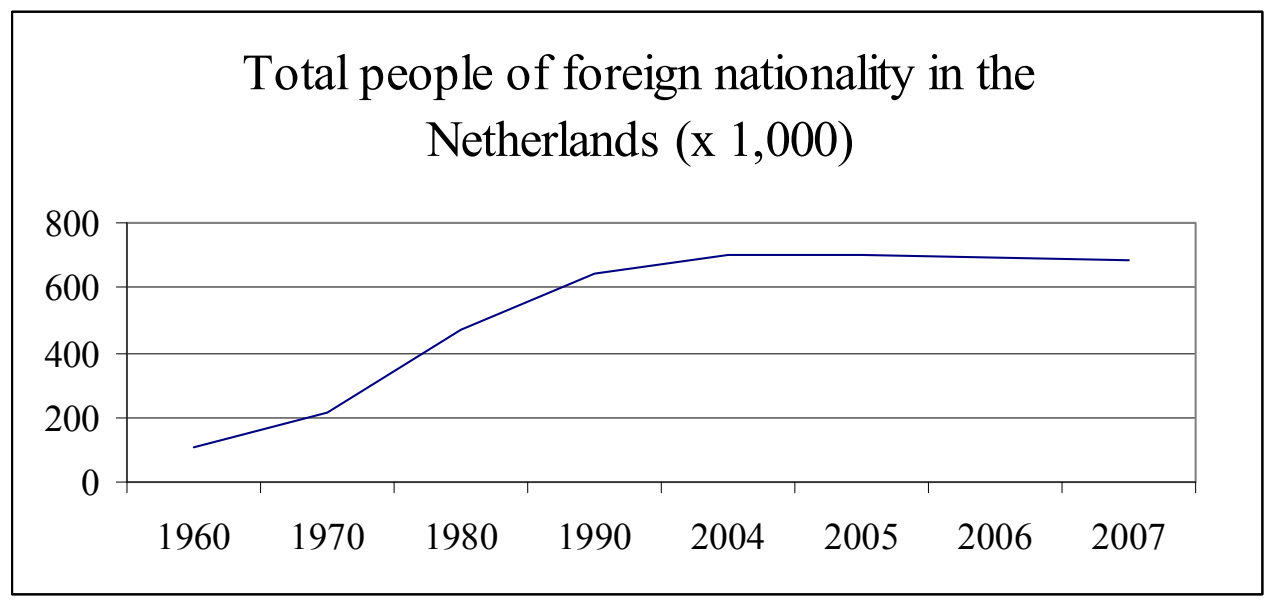

Source: CBS Statline (Dutch Central Bureau for Statistics)

With the increasing stock of migrants have also come increasing remittance flows. It has only been in the last years that remittances have come to the forefront in policy, which is why data is not available for earlier years. In Figure 5.2, there is an increasing trend in remittances between 2002 and 2006. This incredible increase in the remittances statistic can mainly be attributed to two things: (1) more remittance sending and (2) better data reporting. It is important to remember that these flows are those that are captured in the statistics, so this could very well be an underestimation since many informal remittances are not captured in official statistics. 
Figure 5.2:

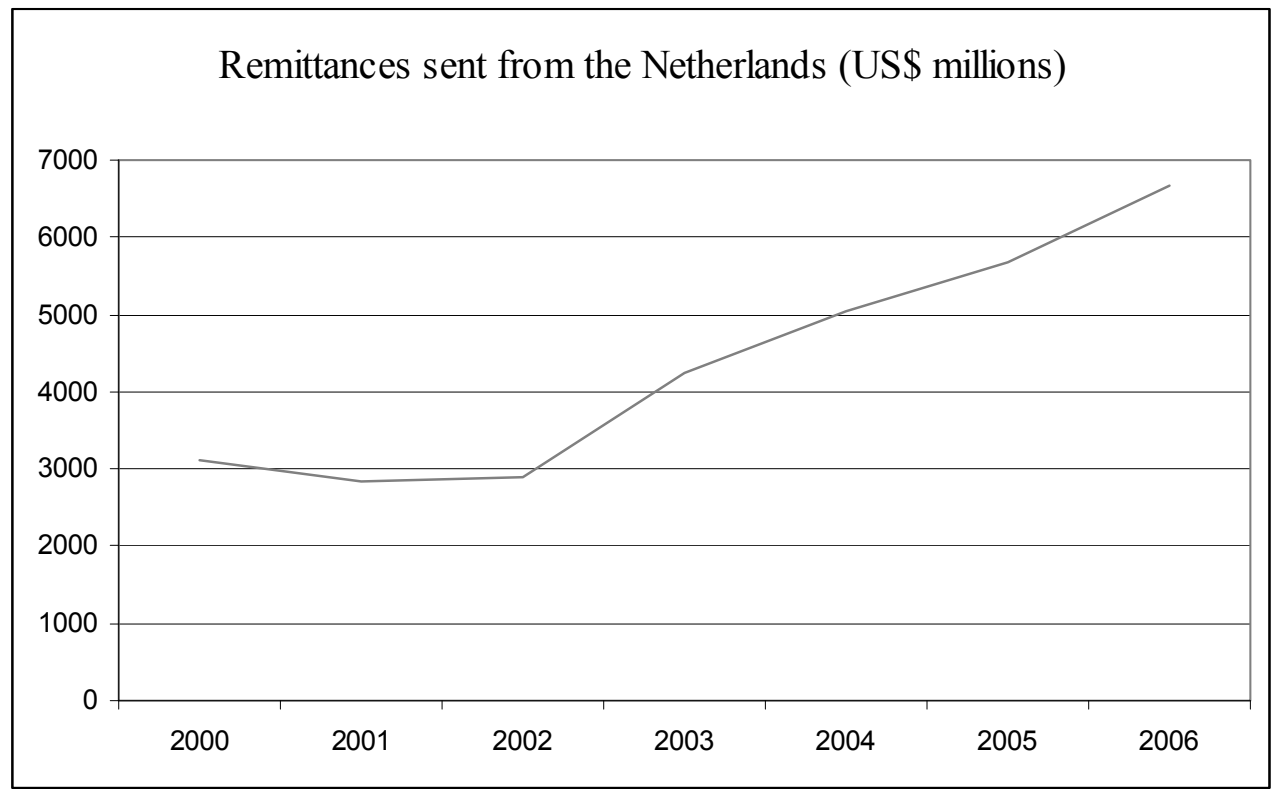

Source: Migration and Remittances Factbook 2008

For this study, we have access to data for six immigrant origin groups (Figure 5.3). Four are the major immigrant groups in the Netherlands (Surinamese, Antilleans, Turks and Moroccans) and the other two (Ghanaians and Somalis) are other migrant origin groups residing in the Netherlands. These six groups do not make up all of the immigrant groups in the Netherlands, but they do represent a majority of the non-western origin population in the Netherlands. The immigrant groups used in this study can be grouped into four different categories with regard to their migration history: colonial migration (Surinamese and Antilleans), guest worker economic migration (Turks and Moroccans), later unrecruited economic labor migration (Ghanaian) and asylum seeker migration (Somalis). The Surinamese, Turks and Moroccans make up the largest number of immigrants, each constituting close to $30 \%$ of the total immigrant origin population. 
Figure 5.3:

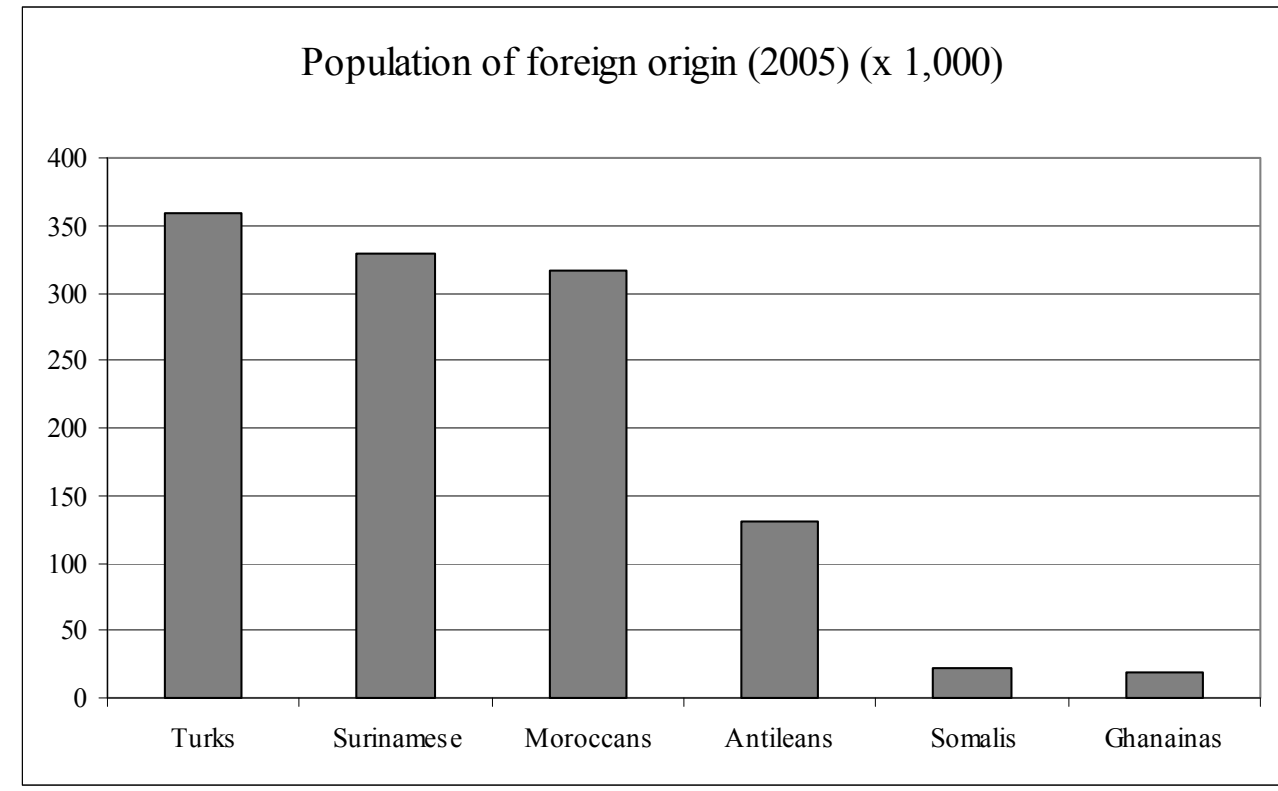

Source: CBS Statline (Dutch Central Bureau for Statistics)

*Foreign origin= at least one parent born in another country

The Netherlands first saw an influx of unskilled migrants from Turkey ${ }^{49}$ and Morocco when they were recruited as guest workers in the 1960s. The intent was that these workers would stay in the Netherlands only a short period of time and then return to their home countries (Guiraudon, Phalet, \& Wal, 2005). After the 1973 oil crisis, the stock of Turks and Moroccans grew due to family reunification which peaked in 1979 and 1980 since labor recruitment had ceased and most of those that had been previously recruited were not returning home. In the 1980s and 1990s, the number of Turkish and Moroccan migrants continued to increase due to marriage migration (a migrant marrying someone from the home country and bringing the spouse to the Netherlands) (Vermeulen \& Penninx, 2000). Today, the Turks and Moroccans make up two of the most populous immigrant origin groups in the Netherlands (Figure 5.3).

Although there was already an established history of immigration from Suriname to the Netherlands, starting mainly in the 1960s, immigration picked up drastically as a result of Surinamese independence in 1975. At that time, citizens of Suriname were given the option of Dutch or Surinamese citizenship. There was another

\footnotetext{
${ }^{49}$ For more background on Turks in the Netherlands and their labor market position, (Euwals, Dagevos, Gijsberts, \& Roodenburg, 2007)
} 
influx of immigrant to the Netherlands between 1979 and1980 when visa requirements were to be imposed on the Surinamese. Unskilled workers began migrated in 1965; those that had migrated previously were more highly skilled migrants (Vermeulen \& Penninx, 2000).

Immigration of Antilleans began in the same way as the Surinamese migration, but peaked in the 1980s (Gijsberts, 2004). Antillean migration in the 1960s was mainly limited to students. The sharp increase in the 1980s, however, was due to the economic conditions in the country after several oil plants on the islands shut down, creating a difficult economic situation and prompting many unskilled workers to migrate to the Netherlands (Vermeulen \& Penninx, 2000).

According to Mazzucato (2005), Ghanaian immigrants began their migration to the Netherlands in the 1980s when the economies of Ghana and Nigeria (the country to which Ghanaians had been historically migrating) began to falter. Immigration increased in intensity in the 1990s. Many Ghanaians view time in the Netherlands as temporary and plan to some day return to Ghana. The Ghanaians began as a small community of migrants in the Netherlands, which eventually grew. Much of the recent migration is due to family reunification and family formation (Kraan, 2001).

Somalis began migrating to the Netherlands in vast numbers during the 1990s; however, their reason for migration was quite different from the later migrant groups. The Somalis traveled to the Netherlands seeking asylum from their wartorn country (Vermeulen \& Penninx, 2000).

There is much less information on the Ghanaians and Somalis living in the Netherlands in the literature and statistics compared with the four major immigrant groups (Surinamese, Turks, Moroccans and Antillean). This chapter uses the sources available to create the most realistic picture possible of these six distinct immigrant origin groups and their remittance practices.

\subsection{An index of immigrant integration in the Netherlands}

In this section, immigrant integration of the six immigrant groups is ranked using several indicators of integration including labor market outcomes, educational attainment, social relations with the native population and social distance, legal rights and citizenship, political voting and representation, welfare dependency and language ability. These variables are indicators of both socio-economic and socio- 
cultural integration. The final outcomes are summarized in Table $2^{50}$, which indicates a rank order of integration with 1 representing the highest degree of integration in each category and 6 representing the lowest degree of integration. The lower the total number at the end, the more integrated the immigrant group relative to the others. This is an ordinal ranking, so it is the relative place that matters and not the size. The outcome of this ranking is then used to evaluate the effect of the immigrant integration on remittance channel choice.

Labor market participation and education are the two characteristics most cited as indicators of immigrant integration (albeit structural economic integration). Vermeulen and Penninx (2000) describe the labor market participation rate and employment rate in 1991 and 1998 for Turks, Moroccan, Surinamese and Antilleans. For both labor market participation and employment, the Surinamese had the best showing, with 66 percent participation in the labor force and a 58 percent employment rate in 1998. Antilleans were a close second with 62 percent and 53 percent respectively. Turks followed next with 47 percent and 37 percent whereas Moroccans trailed with only 44 percent and 34 percent respectively. In Graph 5.1 and Table 5.1 of the Appendix, we witness the same pattern over many years. Historically, the Ghanaians are relatively well educated but lack Dutch language skills and many are illegally living in the Netherlands. As a result, many have jobs below their skill level in the informal economy or no jobs at all (Kraan, 2001). Chiswick and Miller (2001) have shown that refugees are less prepared for the labor market due to the circumstance related to their migration (experiencing traumatic events and extreme stress). In the Netherlands, asylum seekers are not allowed to work while going through the formal procedure to gain refugee status. Therefore, Somalis would likely fall in last place in the labor market participation ranking.

When looking at educational attainment by immigrant group, we see a similar picture with regard to performance as in the previous case. The Antilleans score slightly above the Surinamese with Turks and Moroccans following respectively. Graph 5.2 of the Annex elaborates on the completion of each level of education and highest completion rates. Refugees from Somalia are very poorly educated when compared to Turks and Moroccans (Gijsberts, 2004). This low level of education has put Somalis at a major disadvantage with regard to their possibility of

\footnotetext{
50 This table is not meant to be an exhaustive indication of all the variables that go into immigrant integration but to be a good indication of the integration situation. Other factors that may matter are relative group size, political situation in origin country, immigration policy in destination country, occupation and residential segregation.
} 
obtaining employment. As previously stated, Ghanaians are relatively well educated.

Social relations with the native population are also important for integration. The more contact an immigrant group has with Dutch society, the more likely they will be able to understand each other. One way to measure social relations with the host society is by assesing mixed marriages. Surinamese and Antilleans have more integrated social circles than the other groups. Only $10 \%$ of Moroccans and Turks marry with Dutch natives, whereas $40 \%$ of Surinamese marry Dutch and $60 \%$ of Antilleans enter into marriages with the native population (Gijsberts, 2004). The majority of Turks and Moroccans, by contrast, married partners from their country of origin. In the period between 1990 and 2002, an estimated 60,000 marriage migrants entered the Netherlands from Turkey and Morocco (Gijsberts, 2004). Marriage migration is believed to hamper integration into Dutch society due to poor language skills and low education of the new migrants, as well as greater isolation of the immigrant group (Gijsberts, 2004). In general, Turks and Moroccans tend to have much more contact with people from their own migrant group than they have contact with the indigenous Dutch. This is even more pronounced for the Turks who have a large degree of social control from their group. Since we do not have access to data on intercultural marriage rates for the Ghanaians and Somalis we must look at other indicators of social relations with the native population. The Ghanaians are well organized in associations and organizations that focus on their ethnic identity and cultural habits (Kraan, 2001). Somalis also have a strong focus on their own ethnic group and are usually more segregated from Dutch society due to their migration status.

The notion of social distance, first put forth by Bogardus (1959), suggests that people feel closer to some groups than they do to others according to the degree of understanding between the two groups. According to Portes \& Rumbaut (2001), social distance depends to a great extent on culture, physical appearance and socioeconomic background. Religion is also plays a role in social distance. In this case, the Turks, Moroccans and Somalis would be the most culturally different from the Dutch because they come from a Muslim background, whereas the Surinamese and Antilleans have the closest social distance because they were historically affiliated with the Kingdom of the Netherlands and come from a Christian background. The Ghanaians fall in between these two groups.

Legal rights, citizenship and political participation in the host country are additional factors that must be considered. Heelsum (2001) gives a good overview of the legal rights and citizenship of the four major immigrant groups. Immigrants from the former Dutch colonies have Dutch passports and have legal rights to politically participate in Dutch society. They have a right to vote in elections and to 
become a local or provincial councilor, parliamentarian or governor. Since 1992, Turks and Moroccans have the option of dual nationality. About two thirds of Turks and half of Moroccans have taken advantage of dual citizenship. Those who are non-nationals but residing legally in the country for more than five years have voting rights at the municipal level. Asylum seekers have no voting rights, but those who have gained refugee status have municipal voting rights after five years. According to voter turnout rates at local elections in 1994 and 1998, Turks participated most with as high as 67\% turnout in Amsterdam in 1994. The Moroccans were second and the Surinamese and Antilleans trailed behind. Due to the status of Ghanaians (approximately half are illegal) and Somalis, these groups are much less likely to participate in elections. Additionally, Surinamese and Antilleans are more likely to hold political office.

Welfare dependency has also been cited as an indicator of integration. In this case, higher welfare dependency (the more welfare systems are used) means less integration. One third of the first generation Turkish and Moroccan migrants and one fourth of the Surinamese and Antillean migrants are benefiting from social welfare (Gijsberts, 2004). The Ghanaians are to a large extent not benefiting from social assistance, since legal status in the country would be required to be eligible for benefits. Somali refugees and asylum seekers, on the other hand, rely heavily on social welfare given that in many cases they have no other option because they are not allowed to work while awaiting their verdict as an asylum seeker.

Immigrants who have already been exposed to the host country language before coming to the country are in a better position to learn the language than those who have not been exposed (Tubergen, Maas, \& Flap, 2004). Language skills can be seen as a part of human capital which has a positive impact on immigrant earnings and opportunities in the labor market (Kossoudji, 1988). In addition, better language skills should improve immigrants' abilities to speak with the native population, making interethnic relations better (Espenshade \& Calhoun, 1993; Gordon, 1964). The likelihood of return migration also plays a role in the immigrant's willingness to learn the host language (Chiswick \& Miller, 2001). This may partially explain why the Turks and Moroccans did not put such a high importance on learning Dutch in the beginning as well as the current situation of the Ghanaians. A large number of Ghanaians plan to return to Ghana, and many speak English, which has made it easier for them to continue to not speak Dutch (Kraan, 2001). 
Table 5.1 Immigrant Integration Index

\begin{tabular}{|c|c|c|c|c|c|c|c|c|}
\hline & 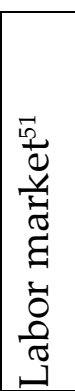 & 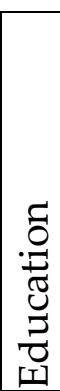 & 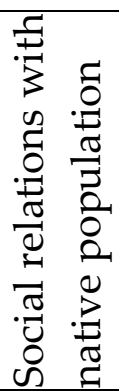 & 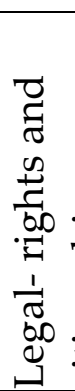 & 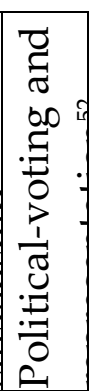 & $\frac{0}{\stackrel{0}{ \pm}}$ & 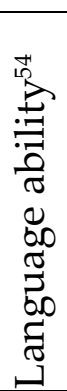 & 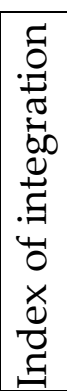 \\
\hline Surinamese & 1 & 2 & 2 & 1 & 2 & 2 & 1 & 11 \\
\hline Antilleans & 2 & 1 & 1 & 1 & 3 & 2 & 2 & 12 \\
\hline Turks & 3 & 3 & 3 & 2 & 1 & 4 & 4 & 20 \\
\hline Moroccans & 4 & 4 & 3 & 2 & 2 & 5 & 3 & 23 \\
\hline Ghanaians & 5 & 3 & 4 & 6 & 4 & 3 & 6 & 30 \\
\hline Somalis & 6 & 6 & 4 & 5 & 4 & 6 & 5 & 36 \\
\hline
\end{tabular}

From the results in Table 5.1 we see that the Surinamese and Antilleans emerge as most integrated with Dutch society, while the Ghanaians and Somalis are least integrated with the Turks and Moroccans falling in between. It is not unexpected to find the Surinamese as the most integrated group of immigrants. According to Gijsberts (2004), the Surinamese have progressed much more with regard to integration into Dutch society over the last several years than the Turks and Moroccans due to their education level, Dutch language ability, extent of family reunification and the size of the second and third generation among other factors. The Surinamese and Antilleans are, on average, socially and culturally closer to Dutch society than the Turks and the Moroccans which is due to differences in religious beliefs and values. While there may be some discussion about the specific indicators chosen here and the values assigned to each group, the ranking is robust and does not change with subtle shifts in values or variables.

${ }^{51}$ (Gijsberts, 2004)

${ }^{52}$ (Heelsum, 2001)

${ }_{54}^{53}$ (Gijsberts, 2004)

${ }^{54}$ The relative better language position of Moroccan to Turks is found in (Tubergen \& Kalmijn, 2005) 


\subsection{Remittance channel choice}

The survey data used in this chapter comes from the Dutch Consumentenbond survey conducted in 2005. It is a survey specifically designed to focus on remittances and interviews the four major immigrant populations in the Netherlands (Moroccans, Turks, Surinamese, Antilleans) and two other migrant groups (Somalis and Ghanaians). The data was collected by Foquz Etnomarketing in 2005 (with the Consumentenbond ${ }^{55}$ as the project manager for the consumer data collection) and was funded by the $\mathrm{NCDO}^{56}$. A sample of 1336 remittance senders $^{57}$ was used to collect data on remittance habits from a target of 240 interviews per immigrant group. The most interviews were done in the three largest Dutch cities: Amsterdam (24\%), The Hague (12\%) and Rotterdam (8\%). Interviews were conducted in March and April of 2005.

As can be seen in the Tables 5.2 and 5.3, banks are of great importance to Turkish migrants. In a paper by Köksal (2006) she gives an in-depth account of the importance of Turkish banks and the role the Central Bank of Turkey ${ }^{58}$ has played in "banking" Turks around the world. It is important to note that while Turkish migrants use banks to a large extent, they are using their native banks and not the banks of the host country.

Although the most important channel through which Moroccans send money is to carry it themselves, we also see that banks are an important channel for this migrant group, coming in as the second most important way to transfer money. This may be explained by the stable economic and political environment as well as particular policies the Moroccan government has set towards migrants (de Haas \& Plug, 2006). De Haas (2003) also finds similar results with regard to the little use of money transfer operators. Since the 1960s, the Moroccan government has encouraged the use of the formal financial sector with the creation of a network or consulates, bank branches and post offices to help assist money transfers. According to de Haas and Plug (2006), remittance transfers through banks already replaced postal transfers in the 1980s and since the end of the 1980s the restrictions on money exchange and the repatriation of money have been lifted. Currency devaluations and fiscal policy favoring migrants have added in bringing

\footnotetext{
${ }^{55}$ Dutch consumer advocacy group.

${ }^{56}$ NCDO stands for Nationale Commissie voor Internationale Samenwerking en Duurzame Ontwikkeling (National Committee for International Cooperation and Sustainable Development).

${ }^{57}$ The breakdown of respondents by ethnic group can be seen in Table 2 of the Annex.

${ }^{58}$ Turkish migrants abroad can open savings accounts at the Central Banks as well as having access to a range of other financial services (Köskal, 2006).
} 
remittances to Morocco through the banking sector. Moroccan banks have also increased their number of foreign offices because migrants are allowed to hold foreign exchange bank accounts with the Central Bank.

The Surinamese and Antilleans show similar remittance sending patterns. They both use money transfer operators (MTOs) as their primary method of sending money and send about 50 percent of remittances formally and the other 50 percent informally. Because of the difficult political situation in Somalia, there is very little access to formal means of sending money. Only 27 percent of transfers are sent formally. The majority of transfers go through hawala-type systems (which are informal money transfer operators), and through cash carried by the sender or someone else. The Ghanaians, on the other hand, are the greatest users of formal services, although they are the lowest users of banks. On average, transfers are slightly more informal than formal on average.

Table 5.2 Immigrant group and remittance channel usage in percentages

\begin{tabular}{|c|c|c|c|c|c|c|c|}
\hline & Turks & Moroccans & Surinamese & Antilleans & Somalis & Ghanaians & Total \\
\hline MTO & 10 & 13 & 31 & 31 & 17 & 51 & 25 \\
\hline Bank & 38 & 25 & 19 & 22 & 10 & 6 & 21 \\
\hline $\begin{array}{l}\text { Total } \\
\text { formal }\end{array}$ & 48 & 38 & 50 & 53 & 27 & 57 & 46 \\
\hline $\begin{array}{l}\text { Self } \\
\text { carried } \\
\text { cash }\end{array}$ & 25 & 30 & 18 & 14 & 17 & 15 & 20 \\
\hline $\begin{array}{l}\text { Call } \\
\text { house, } \\
\text { travel } \\
\text { agent, } \\
\text { other } \\
\text { shop, } \\
\text { hawala }\end{array}$ & 7 & 4 & 13 & 9 & 31 & 16 & 13 \\
\hline $\begin{array}{l}\text { Other } \\
\text { person } \\
\text { carried } \\
\text { cash }\end{array}$ & 8 & 16 & 10 & 12 & 15 & 9 & 12 \\
\hline $\begin{array}{l}\text { Post (in } \\
\text { letter or } \\
\text { package) }\end{array}$ & 4 & 4 & 8 & 9 & 3 & 2 & 5 \\
\hline $\begin{array}{l}\text { Mosque } \\
\text { or Church }\end{array}$ & 7 & 6 & 1 & 0 & 5 & 1 & 3 \\
\hline $\begin{array}{l}\text { Bank card } \\
\text { or credit } \\
\text { card }\end{array}$ & 2 & 3 & 1 & 1 & 0 & 1 & 1 \\
\hline Total & 100 & 100 & 100 & 100 & 100 & 100 & 100 \\
\hline
\end{tabular}

Source: own calculation based from 2005 Consumentenbond survey 
Table 5.3 shows that when banks are used to transfer money, different banks are chosen as the primary bank used for transferring money by different migrant groups. ABN AMRO stands out as the most used, with Postbank following close behind. Turks in particular use foreign (non-Dutch) banks to transfer money (usually Turkish Banks).

\section{Table 5.3: Immigrant group and bank usage in percentage}

\begin{tabular}{|l|c|c|c|c|c|c|c|}
\hline & Turks & Moroccans & Surinamese & Antilleans & Somalis & Ghanaians & Total \\
\hline ABN AMRO & 19 & 31 & 39 & 29 & 29 & 15 & 28 \\
\hline Postbank & 7 & 26 & 26 & 37 & 47 & 46 & 24 \\
\hline $\begin{array}{l}\text { Foreign } \\
\text { banks }\end{array}$ & 52 & 5 & 4 & 2 & 12 & 8 & 21 \\
\hline Rabobank & 5 & 28 & 9 & 16 & 6 & 0 & 12 \\
\hline ING Bank & 5 & 3 & 13 & 4 & 6 & 0 & 6 \\
\hline SNS Bank & 7 & 7 & 7 & 8 & 0 & 0 & 6 \\
\hline Fortis Bank & 6 & 2 & 2 & 4 & 0 & 31 & 5 \\
\hline Total percent & 100 & 100 & 100 & 100 & 100 & 100 & 100 \\
\hline $\begin{array}{l}\text { Total } \\
\text { number of } \\
\text { respondents } \\
\text { using banks }\end{array}$ & 88 & 58 & 46 & 51 & 17 & 13 & 273 \\
\hline
\end{tabular}

Source: own calculation based on 2005 Consumentenbond survey

\subsection{Empirics}

In this section, remittance channel choice is formally tested using a probit model for the decision to remit formally or informally and for the decision to remit through a bank or MTO. We fist look at the decision to remit formally. Once we know who remits formally, then we look at the determinants of remitting through a bank or money transfer operator. In both instances, we are concerned with key independent variables such as remitter characteristics, the integration index, remitter behaviour and political stability in the country of origin. We hypothesize that more integrated immigrants will use formal channels while less integrated will use informal channels. An even more clear differentiation is between banks and money transfer operators. We hypothesize that more integrated immigrants will choose banks more often since then should be the most familiar with banking services. 


\subsubsection{Formal vs. informal remittances}

First, the following equation is estimated using a probit model to explore the determinants of the choice between formal and informal transfers.

$$
F_{i}=\alpha+\beta_{1} I_{i}+\beta_{2} R_{i}+\beta_{3} C_{i}+\beta_{4} B_{i}+\varepsilon_{i}
$$

where $F_{i}$ is a dummy for formal channel choice. $I_{i}$ is the integration index, $R_{i}$ is remitter characteristics, $C_{i}$ is the country of origin characteristics and $B_{i}$ is remittance behavior.

Table 5.4 shows the results of the probit model. The integration index is significant at the $5 \%$ level but is not in line with out hypothesis. The results show that the less integrated the immigrant group, the greater the likelihood of remitting formally (recall higher values mean less integrated). It is possible that the Ghanaians are influencing this result since they use MTOs to a large extent but are not well integrated (recall the descriptive statistics above).

Two of the remitter characteristics are significant; one that is in line with our hypothesis and another that is not, although this can be explained. Having a college education is positive and significant, meaning that those immigrants with at least a college education are more likely to send remittances formally. The number of years a person has been in the Netherlands gives the opposite result. From this, we could extrapolate that those living in the Netherlands for a longer period of time are more likely to send informally while those people living in the Netherlands for a shorter period of time are more likely to send remittances formally. This would go against our hypothesis. One explanation for this could be that this is picking up a kind of "expat effect", meaning that highly skilled people in the Netherlands for a shorter period of time could be pushing this result. Expatriates for highly skilled migrants in the Netherlands for a shorter period of time are more likely to send money formally.

Moving on to remittance (or sending) behaviour, it is clear that those people that send money on a regular basis (between 2 and 12 times per year) are more likely to send remittances formally than those sending only one time per year. There is also a positive effect for those people that send more than 12 times per year, but it is not 
significant. This finding is in line with the idea that regular remittance senders are more likely to use the formal system, perhaps, because they are more familiar with their options. The amount of money sent has a very small but positive effect, so higher amounts of money are associated with formal transfers.

The last variable to concentrate on is political stability in the country of origin. The reason for using this variable is that it should affect the possibility (access) to send money in a formal way since formal providers are often wary of conflict zones or post conflict zones. The data for this variable was taken from the World Bank governance indications for political stability in 2005. The values for this variable can range between -2.5 and 2.5 with 2.5 being the most stable. Table 5.4 clearly shows a relationship between more stability and great formal transfers. Regressions were also run with country of origin dummies and variables for economic development and corruption, but were not used in the final regression due to concerns of collinearity.

Table 5.4 Probit for sending money formally

\begin{tabular}{|l|l|l|}
\hline Variable & Marginal effect & Robust standard error \\
\hline Integration index & .006 & $.003^{* *}$ \\
\hline Age & -.004 & .008 \\
\hline Age squared & .000 & .000 \\
\hline Years in the Netherlands & -.004 & $-.004^{*}$ \\
\hline Born in Netherlands & -.012 & .051 \\
\hline College education & .079 & $.048^{*}$ \\
\hline Sent money between 2 and 12 times & .147 & $.034^{* * *}$ \\
\hline Sent money more than 12 times & .123 & .034 \\
\hline Amount of money sent in year & .000 & $.000^{* * *}$ \\
\hline Political stability & .094 & $.018^{*}$ \\
\hline & & \\
& & \\
\hline Number of obs & 1006 & \\
\hline Wald chi2(10) & 74.71 & \\
\hline Prob > chi2 & 0.0000 & \\
\hline Pseudo R2 & 0.0606 & \\
\hline Log pseudolikelihood & -653.03 & \\
\hline Basicnt & \\
\hline
\end{tabular}

Bases: sent remittances once per year

*significant at the $10 \%$ level

** significant at the $5 \%$ level

*** significant at the $1 \%$ level 


\subsubsection{Bank vs. MTO remittances}

\subsubsection{Specific remittance channel}

The next part of the analysis uses a probit model to distinguish between the choice to send money through a bank or MTO, for those who remit formally. In Table 5.5, the same independent variables are presented as above, only now with bank or money transfer operator as the dependent variable. The choice of bank receives a 1 and MTO a 0 .

The integration index is significant again, but here the more integrated the group, the more likely they are to use Banks instead of MTOs, which is in line with our hypothesis. Age and age squared also becomes significant with opposite effects. So it seems that the younger senders and very old senders are more likely to use banks. This may be because younger people are more likely to have a good idea of the different services that are available while older people may have been around long enough to learn the different options. The greater the number of years in the Netherlands, the more likely it is to use formal services while being born in the Netherlands appears to be associated with greater usage of MTOs. Political stability is the most surprising variable. These result show that the less the political stability, the greater the likelihood of bank transfers. This is difficult to interpret unless there are more banks working in more unstable areas than MTOs. 
Table 5.5 Probit for the decision to transfer through a Bank compared with MTO

\begin{tabular}{|l|l|l|}
\hline Variable & Marginal effect & Robust standard error \\
\hline Integration index & -0.023 & $0.004^{* * *}$ \\
\hline Age & -0.041 & $0.014^{* * *}$ \\
\hline Age squared & 0.000 & $0.000^{* * *}$ \\
\hline Years in the Netherlands & 0.008 & $0.003^{* *}$ \\
\hline Born in Netherlands & -0.133 & $0.067^{*}$ \\
\hline College education & 0.084 & 0.070 \\
\hline Sent money between 2 and 12 times & -0.060 & 0.057 \\
\hline Amount of money sent in year & 0.000 & 0.000 \\
\hline Political stability & -0.143 & $0.029^{* * *}$ \\
\hline & & \\
\hline Number of obs & 468 & \\
\hline Wald chi2(10) & 70.72 & \\
\hline Prob > chi2 & 0.0000 & \\
\hline Pseudo R2 & 0.1070 & \\
\hline Log pseudolikelihood & -28.601 .582 & \\
\hline
\end{tabular}

Base: sent remittances 1 time per year

*significant at the $10 \%$ level

**significant at the $5 \%$ level

${ }^{* * *}$ significant at the $1 \%$ level

\subsection{Conclusions}

Immigrant integration is not the only factor in the remittance channel decision. Integration, as measured here in a rank order, gives mixed results for affecting the decision to remit. Institutional factors and policies may play a larger role in the remittance channel decision. Turkey appears to be a particular case. Turks remit, to a large extent, through banks in spite of the fact that they are one of the middle integrated migrant groups in the Netherlands. This can be explained by the fact that they are mostly served by their own native Turkish banks in the Netherlands. This finding implies that groups that are less integrated may still remit formally because the formal transfers are strongly embedded in their culture or society. There is also a Moroccan banking presence in the Netherlands, and the Moroccan Central Bank makes is attractive for Moroccans to use the formal banking system. Policies which promote migrant sending country involvement can increase the use of formal services, especially banks, and perhaps also facilitate banking the unbanked in the sending country since many migrant families back in the home country do not have bank accounts. 
It is important to keep in mind that immigrant integration is only one of the factors that influence remittance channel choice. In countries where there is little or no formal infrastructure for sending money, formalized remitting is not an option, regardless of how integrated the group is in Dutch society. This is blaringly obvious in the case of the Somalis. Political stability was a key factor in the decision to remit formally and was highly associated with MTO transfers. It is not clear why this is the case. Perhaps it is due to market factors that MTOs are more responsive to than banks.

The overall findings of the relationship between immigrant integration and remittances channel choice lend some evidence to policy makers with regard to immigrant integration in host countries as well as remittance sending. The financial sector may be incentivized to promote migrant integration by the prospect of additional users and consumers of their services. Policy makers interested in the formalization of remittances may first need to consider enabling forces which promote formal remittance sending, such as trust of financial institutions and cultural competency. In addition to all of the other social benefits of a socially cohesive society, we may see a shift from informal to formal remittance sending when thoughtful, culturally sensitive policies are put into place. Ideally, a combination of policies that involve institutional investment and improvements in infrastructure and cultural outreach to vulnerable populations, including immigrants, should be pursed by policy makers. 


\subsection{References}

Alesina, A. and P. Giuliano (2007). "The Power and the Family." National Bureau of Economic Research.

Amuedo-Dorantes, C. (2005). "On the use of Differing Money Transmission Methods by Mexican Immigrants." International Migration Review 39(3): 554-576.

Amuedo-Dorantes, C. (2007). "Labour Market Assimilation of Recent Immigrants in Spain." Journal of Industrial Relations 45(2).

Barro, R. and R. McCleary (2003). "Religion and Economic Growth." American Sociological Review 68: 760-781.

Bertrand, M. and A. Schoar (2006). "The Role of the Family in Firms." Journal of Economic Perspectives 20(2): 73-96.

Bevelander, P. and H. S. Nielsen (2001). "Declining employment success of immigrant males in Sweden: Observed or unobserved characteristics?" Journal of Population Economics 14(3): 455-472.

Bogardus, E. S. (1959). Social Distance. Los Angeles, CA, Antioch Press.

Borjas, G. (1985). "Assimilation, changes in cohort quality and the earnings of immigrants." Journal of Labor Economics 3: 463-469.

Borjas, G. (1995). "Assimilation and changes in cohort quality revisited: What happened to immigrant earnings in the 1980s?" Journal of Labor Economics 13: 201-245.

Borjas, G. (1999). Heaven's Door: Immigration Policy and the American Economy. Princeton, NJ, Princeton University Press.

Chiswick, B. R. and P. W. Miller (2001). "A Model of Destination Language Acquisition: Application to Male Immigrants in Canada." Demography 38: 391-409.

Espenshade, T. T. and C. A. Calhoun (1993). "An Analysis of Public Opinion toward Undocumented Immigration." Population Research and Policy Review 12: 189-224.

Euwals, R., J. Dagevos, et al. (2007). "The Labor Market Position of Turkish Immigrants in Germany and the Netherlands: Reasons for Migration, Naturalisation and Language Proficiency " CBS (Netherlands Bureau for Economic Policy Analysis) Discussion Paper.

Favell, A. (2005). Assimilation/Integration. Immigration and Asylum: From 1900 to the Present M. Gibney and R. Hansen. Santa Barbara, ABC-CLIO Ltd

Fernández, R. and A. Fogli (2005). "Culture: An Empirical Investigation of Beliefs, Work and Fertility." NBER Working Paper 11268.

Gijsberts, M. (2004). Ethnic Minorities and Integration: Outlook for the Future. The Hague, Social and Cultural Planning Office. 
Giuliano, P. (2007). "Living Arrangements in Western Europe: Does Cultural

Origin Matter?" Journal of the European Economic Association 5(5): 927952.

Gordon, M. M. (1964). Assimilation in American Life. New York, Oxford University Press.

Guiraudon, V., K. Phalet, et al. (2005). "Monitoring ethnic minorities in the Netherlands." UNESCO.

Guiso, L., P. Sapienza, et al. (2006). "Does Culture Affect Economic Outcomes?" Journal of Economic Perspectives 20(2): 23-48.

Haas, H. d. (2003). Migration and Development in Southern Morocco: The Disparate Socio-Economic Impacts of Out-Migration on the Todgha Oasis Valley. Nijmegen, Radboud University Nijmegen. PhD.

Haas, H. d. and R. Plug (2006). "Cherishing the Goose with the Golden Eggs: Trends in Migrant Remittances from Europe to Morocco 1970-2004." International Migration Review 40(3): 603-634.

Hartog, J. and R. Winkelmann (2003). "Comparing migrants to non-migrants: The case of Dutch migration in New Zealand." Journal of Population Economics 16: 683-705.

Heelsum, A. v. (2001). Political Participation of Migrants in the Netherlands. Metropolis Conference, Rotterdam.

Köksal, N. E. (2006). "Determinants and Impact on the Turkish Economy of Remittances." Working Paper.

Kossoudji, S. A. (1988). "English Language Ability and the Labor Market Opportunities of Hispanic and East Asian Immigrant Men " Journal of Labor Economics 6: 205-28.

Kraan, M. (2001). Blijven of teruggaan? En sociologische analyse van potenties en problemen van Ghanezen in Amsterdam Zuidoost, Vrije Universiteit Amsterdam.

Longva, P. and O. Raaum (2002). "Unemployment and earnings assimilation of immigrants." Labour 16: 469-89.

Mazzucato, V. (2005). "Ghanaian migrants' double engagement: a transnational view of development and integration policies." Global Migration Perspectives 48 .

McCleary, R. and R. Barro (2006). "Religion and Economy." Journal of Economic Perspectives 20(2): 49/72.

Portes, A. and R. G. Rumbaut (2001). Legacies: The Story of the Immigrant Second Generation. Berkeley, CA, University of California Press.

Ratha, D. and Z. Xu (2008). Migration and Remittances Factbook 2008 Washington. D.C. , World Bank.

Schmidt, C. M. (1997). "Immigrant performance in German: Labor earnings of ethnic German migrants ad foreign guest-workers." Quarterly Review of Economics and Finance 37: 379-397. 
Schoeni, R. F. (1998). "Labor market assimilation of immigrant women." Industrial and Labor Relations Review 51: 483-504.

Snel, E., G. Engbersen, et al. (2006). "Transnational involvement and social integration." Global Networks 6(3): 285-308.

Tabellini, G. (2006). "Culture and Institutions: Economic Development in the Regions of Europe." Working Paper.

Tubergen, F. v. and M. Kalmijn (2005). "Destination-Language Proficiency in CrossNational Perspectives: A Study of Immigrant Groups in Nine Western Countries." American Journal of Sociology 110(5): 1412-57.

Tubergen, F. v., I. Maas, et al. (2004). "The Economic Incorporation of Immigrants in 18 Western Societies: Origin, destination, and Community Effects." American Sociological Review 69: 704-727.

Vermeulen, H. and R. Penninx (2000). Immigrant Integration: The Dutch Case. Amsterdam, Het Spinhuis.

Wheatly, P. S. (1999). "The employment adjustment of male immigrants in England." Journal of Population Economics 14(1): 193-220.

World Bank (2005). Global Economic Prospects 2006: Economic Implications of Remittances and Migration. Washington, D.C., World Bank. 


\section{Appendix 5}

Figure A5.1:

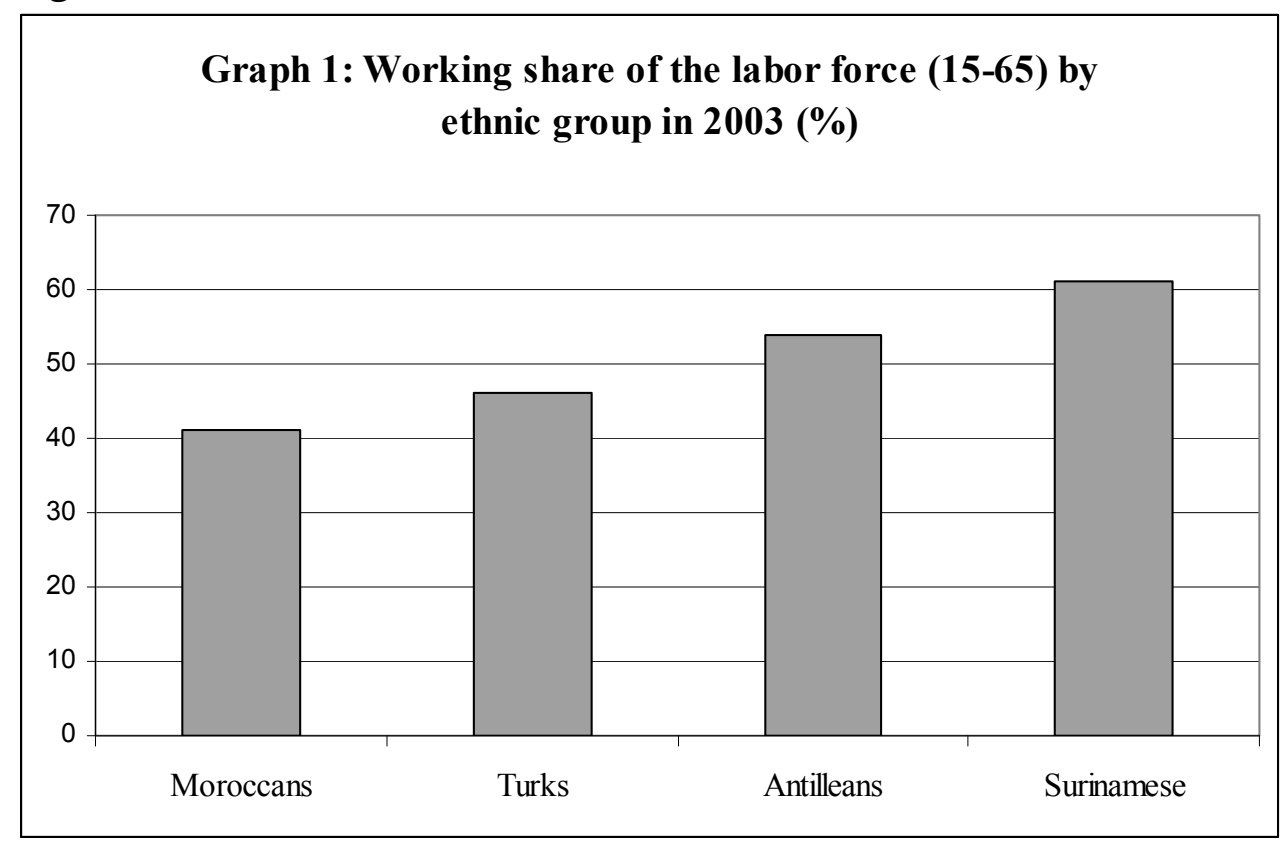

Source: SCP treatment (Dagevos et al. 2003) in (Gijsberts, 2004)

Table A5.1: Share of the total migrant population (including nonworkers) with a job of at least middle-ranking level, 1991-2002 (in percent)

\begin{tabular}{|l|c|c|c|c|}
\hline & 1991 & 1994 & 1998 & 2002 \\
\hline Turks & 7 & 10 & 9 & 13 \\
\hline Moroccans & 6 & 7 & 8 & 15 \\
\hline Surinamese & 19 & 21 & 28 & 32 \\
\hline Antilleans & 16 & 27 & 27 & 32 \\
\hline
\end{tabular}

Source: ISEO (SPVA'91 and '94); ISEO/SCP (SPVA '98 and '02); CBS (EBB '91,'02) in (Gijsberts 2004) 
Figure A5.2:

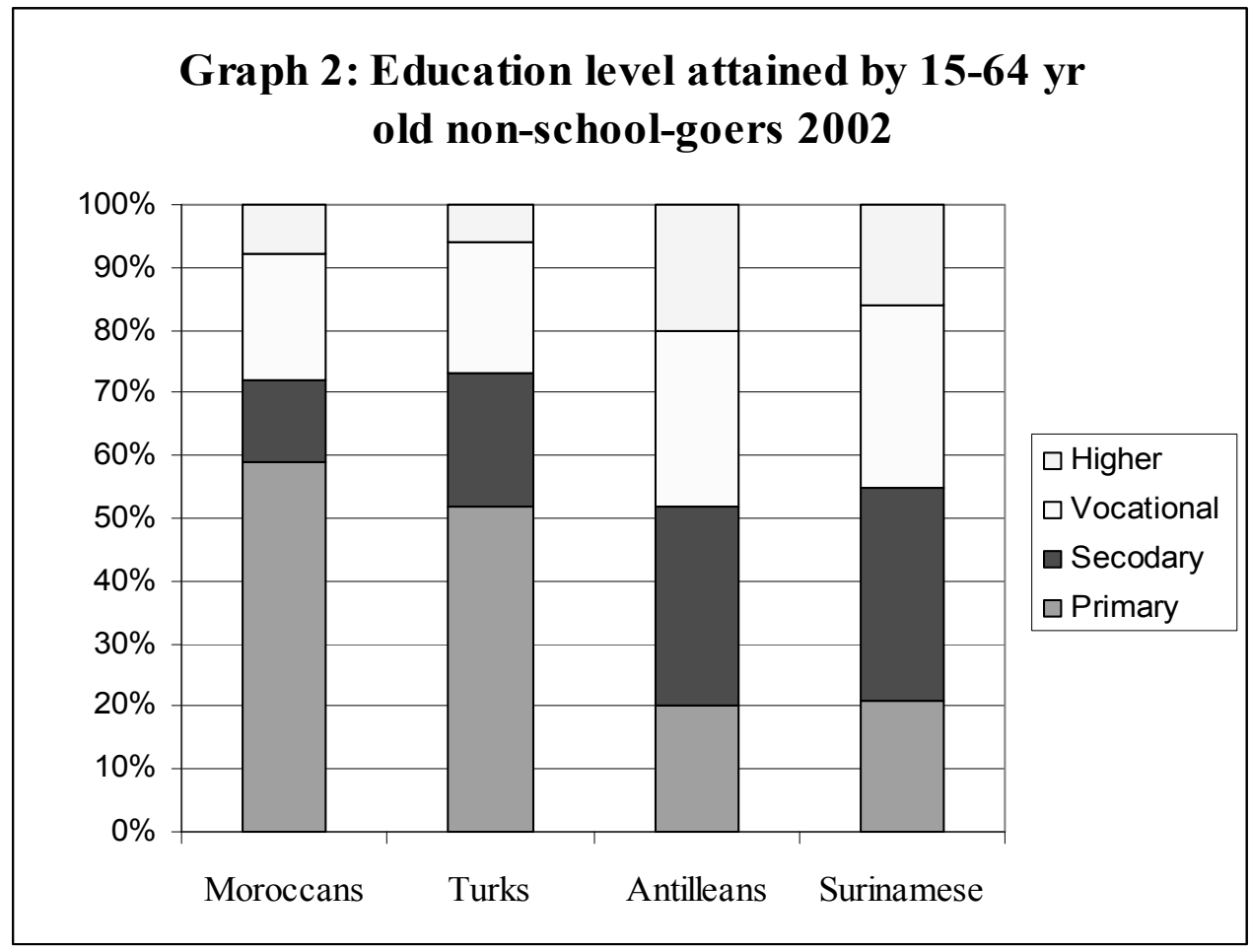

Source: ISEO/SCP (SPVA '02), CBS (EBB'02), SCP treatment (Degevos et al. 2003) in (Gijsberts, 2004)

Table A5.2: Respondent country of origin

\begin{tabular}{|l|c|c|}
\hline & Frequency & Percentage \\
\hline Moroccan & 224 & 18 \\
\hline Surinamese & 243 & 18 \\
\hline Antilleans & 234 & 18 \\
\hline Turks & 229 & 17 \\
\hline Ghanaians & 211 & 16 \\
\hline Somalis & 175 & 13 \\
\hline Total & 1136 & 100 \\
\hline
\end{tabular}

Source: own calculation based on 2005 Consumentenbond survey 
Chapter 6: Migration effects on health expenditure: The Moldovan Experience

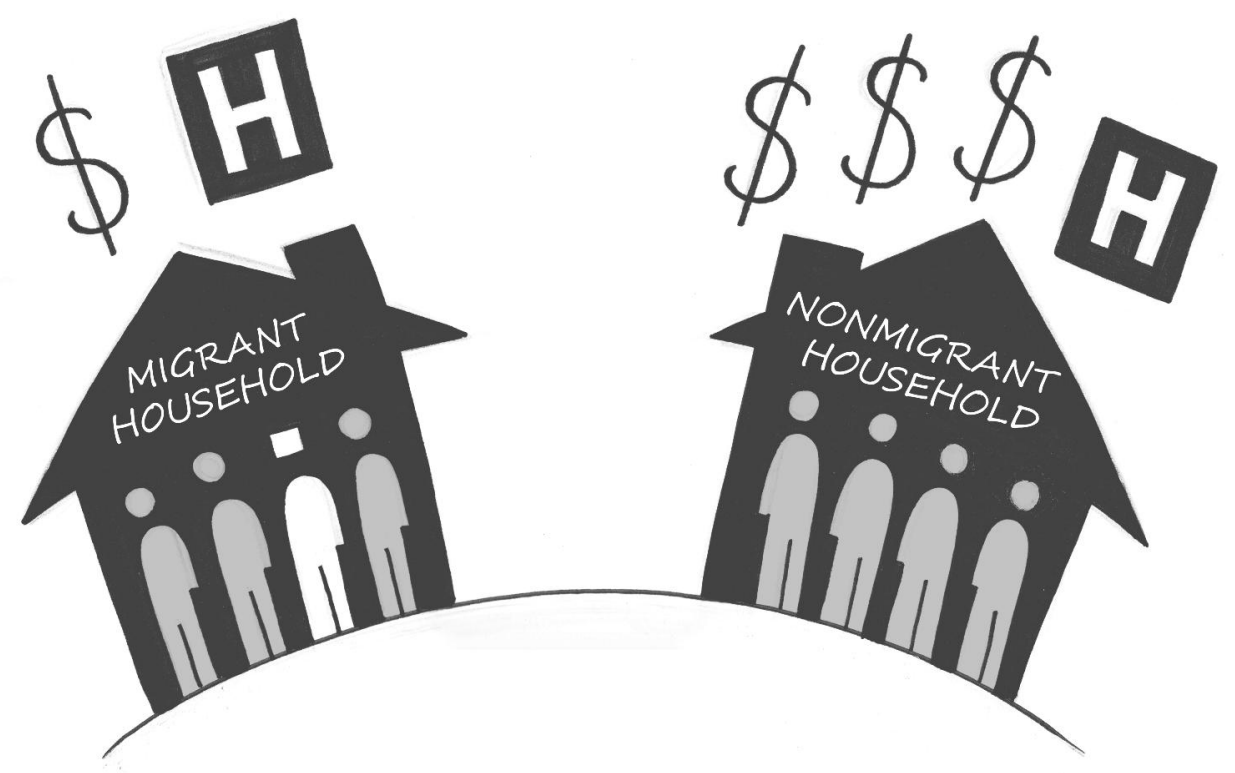




\subsection{Introduction ${ }^{59}$}

With the expansion of the global economy, economic migration and the associated income diversification for migrant households have become more common worldwide (López-Córdova \& Olmedo, 2007). Economic migration refers to temporary, seasonal, cyclical or permanent movement into another country or region within one's own country for the purpose of economic gain; economic migration may be international or intra-national. Although international and intranational migration can be quite similar in terms of motivating factors, opportunity to migrate and the overall economic impact on household welfare, this paper limits the analysis to international migration only. Generally, (international) economic migrants retain strong relationships with families and communities in their home country, hereafter referred to as the "sending country". Earnings from work abroad are remitted back to people in the sending country through various formal and informal channels. These remittances are impressive in magnitude and interesting from a policy perspective due to their potential impact on poverty alleviation, gains in human capital and economic development on the household level. Indeed, worldwide remittance flows to developing countries were estimated to be at least US \$ 318 billion in 2007 (Ratha \& Xu, 2008) and many argue that economic migration and remittance sending may be one of the most important mechanisms by which human welfare can be improved in resource-poor settings (Adams, 2005; López-Córdova, 2005; McKenzie \& Sasin, 2007). Evidence on the welfare effects of economic migration and the related remittances "back at home", that is, within migrant sending countries, is, however, very limited. Even scarcer is information about the relationship between economic migration and the health of household members in the sending country. Migration is believed to affect the health of sending country households in different ways; these effects are not necessarily unidirectional or predictable. Therefore, empirical research is necessary to describe and quantify the potential effect of economic migration and remittance sending on health indicators and household investment in health in the sending countries. The micro analysis in this chapter contributes to the literature by testing the effects of migration on healthcare expenditure in Moldovan households with at least one member who migrated internationally.

\footnotetext{
${ }^{59}$ This chapter is based on joint work with Stephanie Wheeler at the University of North Carolina, Chapel Hill.

* This paper has benefited from comments by the participants at the MGSoG 2008 Summer School, Joan Muysken and UNC Public Health researchers.
} 
Section 2 discusses the existing literature on migration, human capital accumulation, and health in general. In section 3, we narrow the discussion to trends in Moldova from the beginning of the massive migratory changes starting in 1999. In section 4, we describe our dataset and measurement of variables of interest, followed by a discussion of methodological challenges and the empirical models used to test relationships between migration and health expenditure in section 5. Our results are presented in section 6 and section 7 concludes with a discussion of the policy relevance, study limitations, and future research.

\subsection{Migration, human capital and health}

Most of the literature on globalization focuses on macroeconomic effects related to the expansion of global economic opportunities and increased exchange of goods and capital; migration of individuals for economic purposes, however, remains largely understudied (López-Córdova \& Olmedo, 2007). Migration of workers may have considerable macroeconomic and microeconomic effects. From a macroeconomic perspective, migrant remittance sending may overcome many of the problems of credit market failure, income inequality, currency devaluation, and lack of domestic employment that afflict underdeveloped countries (Acosta, 2007; López-Córdova \& Olmedo, 2007; Taylor \& Mora, 2006). From the household perspective, migrant remittance sending may alleviate immediate financial crises as well as increase both short and long-term consumption and investment/savings (Acosta, 2006). In particular, at the household level, remitted funds may be used to finance gains in human capital, including investment in education and health. Much of the literature is devoted to discussions of type of remittance spending (Taylor \& Mora, 2006). Some authors argue that the vast majority of remittances are spent on consumption and that historically, household investment/savings of remittance funds is rare and largely "unproductive" for the national economy (Chami, Jahjah, \& Fullenkamp, 2003). We would argue that remittance spending related to health and education is in many ways unique, in that both consumption of goods and services (e.g., purchase of nutritious food or school uniforms and books) and investment/savings (e.g., preventive health care utilization and human capital investment) may multiplicatively lead to improvements in social welfare of individuals. Therefore, discussions of whether remittances are (should be) used for consumption or investment seems strange in the context of health and education since they can be regarded as having both a consumption and investment effect. Improvements in health and education can be viewed as human capital gains. Moreover, it should be noted that it is difficult to trace the use of remittances in the consumption pattern of receiving households as the consumption financed out of remittances may substitute current expenditures of 
households out of other resources and may be saved (and thus remain largely unobserved).

Our analysis contributes to the rather thin literature on the effects of migration on human capital maintenance and accumulation, more specifically on health care expenditures within the receiving households. Educational aspects of migration and remittances on human capital formation are relatively often discussed compared to the health aspects of remittance sending (Acosta, 2006; Adams, 2005; Cox-Edwards \& Ureta, 2003; Mansuri, 2006a, 2006b; Yang, 2004). Several papers have examined the effect of migration or remittances on child schooling or educational attainment. Acosta (2006) found that children in El Salvador within migrant sending households were more likely to be enrolled in school, compared with households with no migrants. Previously, (Cox-Edwards \& Ureta, 2003) provided evidence that remittances reduced school dropout rates in the same country. Examining education in the Philippines, (Yang, 2004) found that currency appreciation, due to remittances, increased migrant children's schooling and decreased child labour participation. Hanson \& Woodruff (2003), in their study of household migration in the Mexican context, found that child educational attainment was positively related to having a family member living abroad. Finally, (López-Córdova, 2005) has demonstrated that in Mexico, remittances can increase school attendance within the sending household, while at the same time decreasing infant mortality and child illiteracy.

When health is addressed in the migration literature, it usually concentrates on the utilization and costs of healthcare for the migrant within the host country, as opposed to health status of household members left behind (Beckman et al., 2004; Burns \& Harrison, 2007; Cots et al., 2008; DeMaria, 2005; Miclutia, Junjan, Popescu, \& Tigan, 2007). Not surprisingly, evidence that focuses entirely on migrant health within the host country is wrought with political controversy, including concerns about migrant "burden" on the host country health system (irrespective of the health financing system in place) and apprehension with respect to communicable disease transmission from migrants - who often have poorer health and lower socioeconomic status than host country residents - to host country residents. Recent concern over transmission of multi-drug resistant tuberculosis by migrants is one notable example (Ellis et al, 1996 - Saudi Arabia; Villarino et al, 1992 - USA; Anh et al, 2000 - Vietnam; Weis et al, 2001 - USA).

Increasingly, policymakers and researchers are recognizing the potential importance of migrant sending household health as an outcome of labour force participation of its members abroad (economic migration). However, measurement of health indicators has been primarily limited to infant mortality (Hildebrandt \& McKenzie, 2005; Kanaiaupuni \& Donato, 1999; López-Córdova, 
2005) and infant birth weight (Frank \& Hummer, 2002; Hildebrandt \& McKenzie, 2005; McKenzie, 2005). Although these common health statistics are clearly valuable indicators of health status, they cannot assess investment in health, outof-pocket payments for preventive or treatment-focused healthcare or willingness to pay for health-related expenditures. Our analysis addresses this gap in our understanding of the effects of migration by assessing household level spending on healthcare using migrant sending household surveys. We compare healthcare spending of migrant sending households to that of non-migrant sending households, controlling for known covariates determined to be important in the migration literature. In focusing our study on Moldova, we examine a unique Eastern European setting which has experienced high levels of economic migration in part as a result of the collapse of the former Soviet Union. The influence of migration and remittance on household health expenditure has not been explored in this setting.

Existing research on migration and remittances is unfortunately plagued with many design and analytical controversies and issues (McKenzie \& Sasin, 2007). These include: (1) the inability to separate remittance sending from migration ${ }^{60}$, (2) selection biases in the decision to migrate, (3) possibility of reverse causality in cross-sectional surveys, and (4) lack of high quality household and individual-level data. The first three can essentially be thought of as problems of endogeneity, whereas the fourth problem is related to research design and data collection. Briefly, endogeneity in this context arises when unmeasured variation between individuals drives the decision to migrate and healthcare expenditures ("omitted variable bias"), or when healthcare expenditures or the demand for healthcare determines the decision to migrate ("reverse causality"). In the latter case, it is conceivable that households with sicker individuals have higher demand for healthcare, which may in turn motivate another member of the household to consider economic migration to defray healthcare costs. This issue is related to research design and data collection, in that experimental studies and panel data could potentially address directionality in causal analyses. However, conducting a randomized experiment - which would potentially eliminate concerns with both selection bias and direction of effect - would be nearly impossible in practice due to costs and ethical concerns. Natural experiments, in the form of visa lotteries, may be the closest we can come to the gold standard of randomized, controlled trials in migration and human capital research (McKenzie, Gibson, \& Stillman, 2006).

\footnotetext{
${ }^{60}$ It is not always clears if it is the money sent back or other outcomes of migration that are driving effects.
} 
Many authors have chosen to ignore selection bias and endogeneity, assuming that the magnitude of any resulting bias is small; these authors have estimated reduced form equations and interpreted their results causally, despite econometric concerns. However, in an interesting study comparing non-experimental methods to an experimental benchmark, McKenzie et al (2006) determined that nonexperimental techniques resulted in as much as $82 \%$ overestimation of the effect under consideration. Their analysis further showed that a good instrumental variable (IV) approach (with $\sim 9 \%$ bias) was preferable to a difference-in-difference estimator (20\% bias), a pre-post difference estimator ( $25 \%$ bias), propensity score matching (19-33\% bias), OLS (31\% bias), and badly designed instrumental variable approach (using a poor instrument) (82\% bias) (McKenzie, Gibson, \& Stillman, 2006). As such, in the absence of an experimental trial, and specifically a randomized experimental trial, the next best alternative is likely use of the instrumental variable technique, conditional upon selection of a good instrument. According to McKenzie \& Sasin (2007), "A powerful instrument can eliminate problems of endogeneity, omitted variables, and measurement error.

Instrumental variables used to correct for potential endogeneity in migration studies in the past include 'randomization allocation processes' (natural experiments in the form of visa lotteries), 'distance from national borders' (McKenzie, Gibson, \& Stillman, 2006), 'natural shocks such as rainfall' (Munshi, 2003), 'cultural and political factors' (Mansuri, 2006a, 2006b), 'the presence of social networks' (Acosta, 2006), 'historical factors' (McKenzie, 2005), and 'economic shocks' (Yang \& Martinez, 2006). Drawing upon this literature, we estimate potentially biased two-part models and compare the results to 'Instrumental Variable Estimation' using 'community-level migrant network' as the instrument.

\subsubsection{Demand for health}

In the Moldovan data base we observe health expenditures; it is the objective of the article to relate these health expenditures to remittances in order to analyse whether the remittance flows change the health care consumption of migrant sending households. The demand of health care facilities, however, is not just a normal consumption good; it shows specific peculiarities that have to be taken into account when estimating its relationship with remittances. Grossman (1972) seminal article was the first to construct a model for the demand for health. In this paper we do not look at the demand for health in the strict sense, but at actual health expenditures which in turn, are a manifestation of the demand for health services. Age and education are the two main determinants that Grossman discusses. Following from Grossman's model of the demand for health and health capital accumulation, Folland, Goodman, \& Stano, (2004a) show that elderly people purchase a greater amount of health care. Older people consume three to 
four times more health care than the young (Folland, Goodman, \& Stano, 2004b). Similarly, according to Grossman's theory, educated people will choose higher optimal health stock than less educated people. This may explain the widely observed correlation between health status and education (Folland, Goodman, \& Stano, 2004a), educated people being healthier. Gerdtham and Johannesson (1999) find that demand for health increases with income and education and decreases with age, urbanization, being over weight and being single. Folland et al.(2004b) explain that differences in health care usage also depend on whether individuals live in urban or rural settings. Often rural dwellers use health care less; whether this has to attributed to cultural and value differences between rural and urban areas or whether this is due to longer distances to health care facilities in rural areas, is not clear.

Demand for health and health expenditure do not necessarily coincide. Wealthy and educated people usually have a higher demand for health and may make lifestyles choices accordingly so that they do not get sick often and do not need to use medical services. On the other hand they may spend more on preventative care because of their high demand for good health. Those individuals with low demand for health may actually end up spending more on health care since they did not take preventative measures to avoid large problems in the future. These factors have to be taken into account when analysing the relationship between health care expenditures of households and the inflow of remittances from abroad.

\subsection{The Moldovan context}

The number of Moldovans who migrate to other countries for the purpose of economic gain has grown rapidly since 1999. Unsurprisingly, remittances have also grown with the increases in the number of migrants working outside the country. Currently, up to one quarter of Moldova's total economically active population is working abroad with incoming remittances constituting more than one third of GDP in 2006 (Lücke, Mahamoud, \& Pinger, 2007).

Historically, the late 1990s marked the lowest point in an economic decline in GDP following the disintegration of the former Soviet Union (Lücke, Mahamoud, \& Pinger, 2007). Previously, under the central planning system, Moldova was the diversified agricultural producer for the Soviet market (wine, wheat, sunflower, beet sugar, fresh fruits and vegetables). As a result, the Moldovan share of agricultural production was far higher than would be sustainable without the explicit and implicit subsidies that Moldova received under the central planning system. After the disintegration of the Soviet Union, Moldova's terms of trade 
were seriously damaged when world market prices were gradually introduced in trade between the former Soviet republics now independent countries. Export prices for agricultural products declined, while energy imports became far more expensive. The crisis in the Russian Federation of 1998 further caused the demand for Molodva's exports to collapse (Siegel \& Lücke, 2008). At the same time, two domestic developments intensified the pressure on household incomes: (1) the large government deficit became unsustainable, and the government implemented aggressive expenditure cuts in 1998 and 1999, and (2) collective agricultural operations were privatized at this time, leading to a loss of jobs at communal farms and a wide-spread return to small-scale and subsistence agriculture (Lücke, Mahamoud, \& Pinger, 2007).

\section{Figure 6.1. Labour migrants, 1999-2008 (thousands; 1999-2005}

\section{adjusted)}

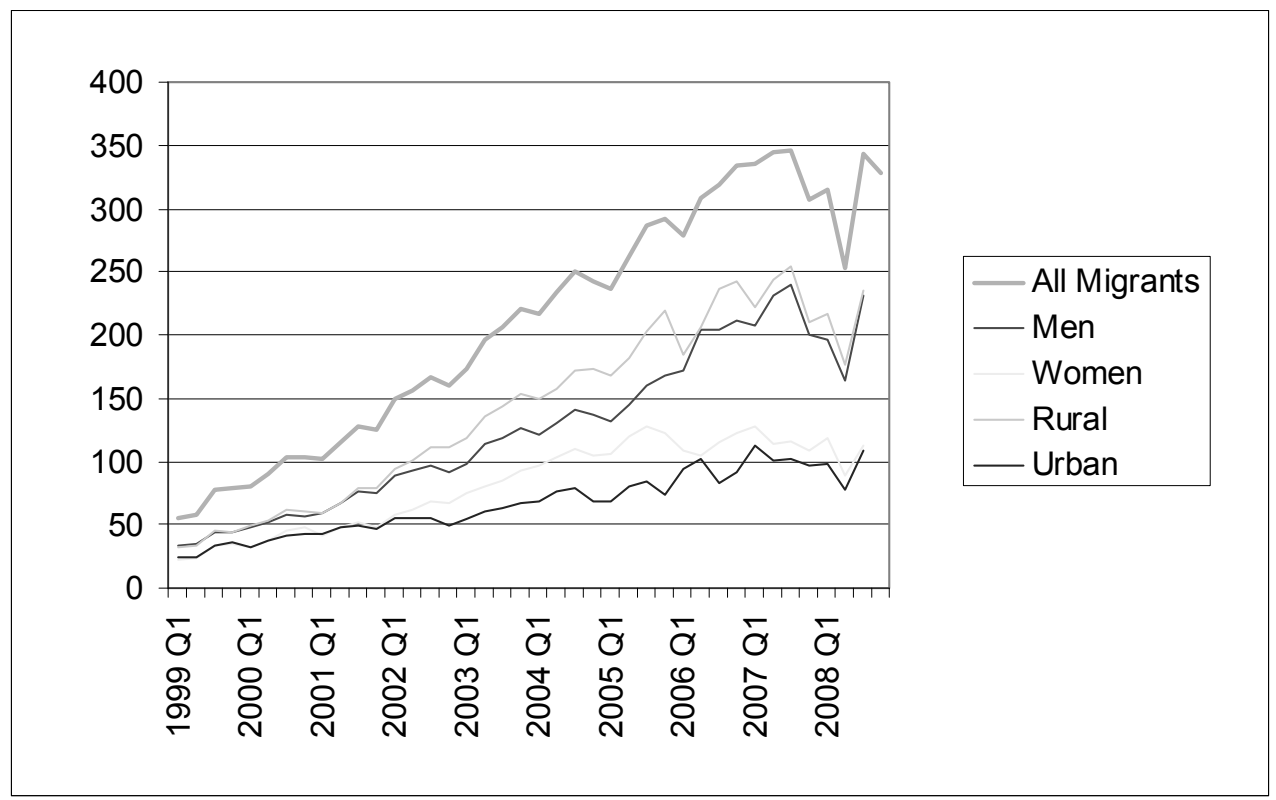

Due to the difficult economic position in Moldova, many people looked to international migration as a means to increase household income. Economic migration from Moldova began to noticeably increase in the late 1990s and early 2000s (Figure 6.1). Pull factors, such as higher incomes and a broader range of employment opportunities abroad made migration an attractive option for families. The growth in the number of labour migrants abroad has increased dramatically between 1999 and 2006 (Figure 6.1). By the end of 2006, the total migrant population amounted to approximately 350,000 individuals abroad; since migration is largely seasonal, the total number of individuals abroad for periods of time during the course of a calendar year may be at least one third higher (Siegel \& 
Lücke, 2008). These time series data are based on raw figures from the Labour Force Survey (LFS) for Moldova; however, they have been adjusted by Lücke, Mahamoud, \& Pinger (2007) for the substantial overestimate of the number of economic migrants under the "old" LFS methodology.

In line with increased economic migration, incoming remittances from Moldovan workers abroad have grown rapidly since 1999 and amounted to approximately US $\$ 1.2$ billion in 2006, or more than one third of GDP in that year (Figure 6.2). This number reflects electronic transfers through the banking system, including payments through money transfer operators (MTOs) according to the methodology of the National Bank of Moldova, as well as estimates of informally transmitted remittances. The latter are based on the turnover of foreign exchange offices (foreign exchange cash converted into Moldovan Lei) as well as estimates of the volume of important transactions typically conducted with foreign exchange cash (apartment purchases, car imports).

\section{Figure 6.2 Migrant remittances from National Bank estimates, electronic transfers and money transfer operators, 2000-2008 (US\$ million; 2008 estimated)}

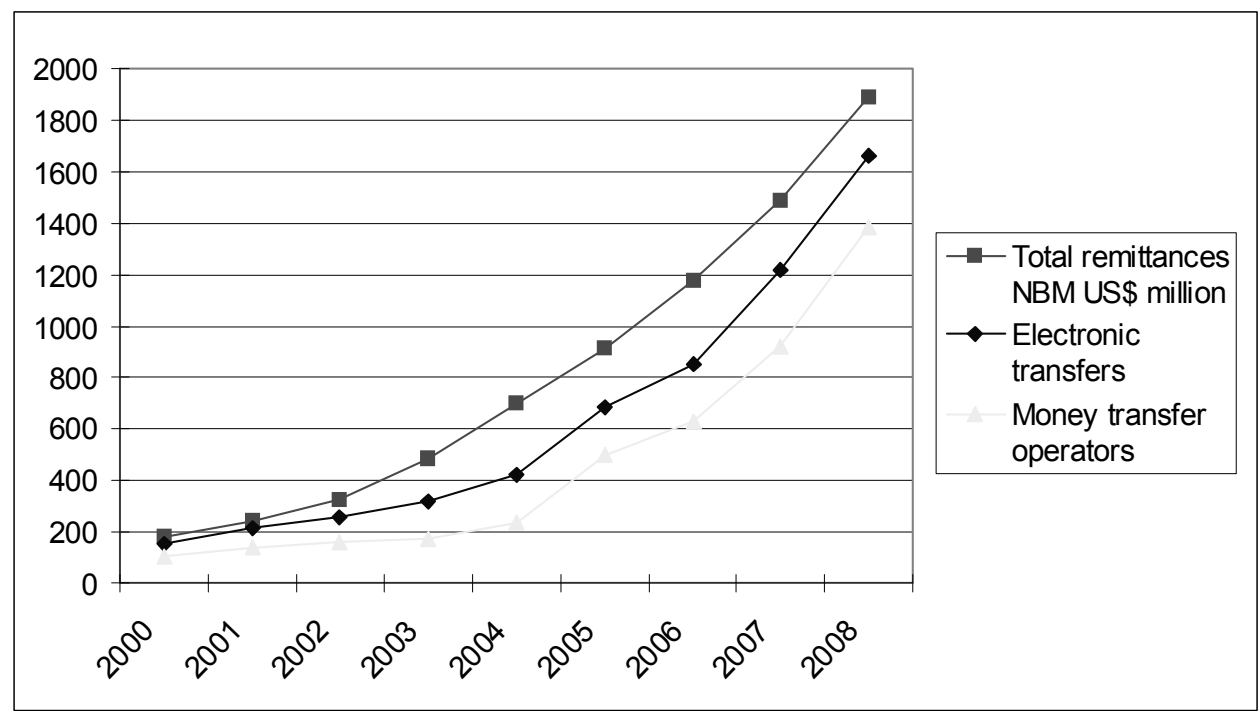

Like many underdeveloped countries experiencing advances in nutrition, housing, and economic growth, the overall health of Moldovan citizens has improved in the last decade (WHO, 2007). Infant mortality and maternal mortality rates have declined, and infant birth weight and life expectancy have gradually increased since 1997 - the period before extensive Moldovan labour migration (WHO, 2007). It is unclear to what we can attribute these advances in health, but part of the 
reason could be related to remittance sending and increased use of remittances to fund health-related goods and services. Although private, out-of-pocket health spending is not necessarily directly correlated with improvements in health status, health spending in theory leads to receipt of appropriate health care in a timelier manner, which is certainly an improvement over not being able to afford any health care at all. Consider the differences between spending on preventive care versus spending on emergencies (serious or crisis health procedures that could have been avoided, had health care been sought earlier). Increased capacity to afford preventive and/or management services earlier in time is likely to defray more serious health and financial costs in the future. In order to judge the effect of these mechanisms, panel data would be needed, but panel data on health expenditures over time are unfortunately not available in Moldova. For this reason, we use cross-sectional survey data on households' out-of-pocket health expenditures as a measure of current consumption and investment in health. This is a good measure, since despite the theoretically available government-provided universal health insurance in Moldova, in reality, people are not treated without additional out-of-pocket expenditures. This means that people must actually pay for their health care in Moldova. This turns out-of-pocket health expenditures into a good indicator given the Moldovan situation.

\subsection{Data}

The need for more reliable and richer data on migration and remittances in Moldova was widely perceived by national policymakers and the donor community. In response, the Moldova offices of several international organizations (IOM, EU Food Security Program, IMF) commissioned the CBS-AXA opinion research firm in 2004 to conduct a nationally representative household survey in order to establish a more solid information base on the determinants and the welfare effects of migration and remittances at the household level. A modified and more streamlined IOM/CBS-AXA survey was repeated in 2006; we use the 2006 survey data for this analysis.

A detailed analysis of household level characteristics and migration practices is necessary, since Moldovan migrants vary in terms of skills, education levels, regional background, and pre-migration family income. These socioeconomic and regional factors are likely similar within household. By contrast, we expect to observe greater between-household variation with respect to these factors, and these may affect both migration sending practices as well as consumption and investment trends within households over time. 
In terms of comparison, we aimed to examine health expenditures of migrant sending households compared to non-migrant households. Accordingly, the CBSAXA survey was designed to sample migrant sending and non-migrant households. The survey is representative of Moldovan households at the national level (excluding Transnistria), with weighted sampling for each major geographic region (North; Center; South; Chisinau) and for each major type of locality (large cities such as Chisinau and Balti; other towns; villages). The total number of households interviewed was close to 4,000. Households interviewed were selected in accordance with a quasi-random sampling scheme. Compared with a standard, stratified, random sampling scheme, the quasi-random approach ${ }^{61}$ has the advantage of being cheaper to implement while generating results that are normally very similar to true random sampling.

Our main dependent variable, health expenditure, was measured by asking household respondent how much was spent on healthcare and/or health-related goods and services in an average month. We examined several different specifications of health expenditure, including (1) whether or not households had any health expenditures (binary variable), (2) absolute household health expenditure per capita (continuous variable with no upper bound), and (3) the ratio of household health expenditure per capita over total household expenditure per capita (0-1 continuous variable).

Our main explanatory variable, migrant sending status, was measured by asking the household respondent whether a household member was currently abroad or has ever lived abroad for more than 3 months since 1991. We assessed the effect of migrant sending status in empirical estimations in two ways: (1) we included migration as a 0 or 1 variable reflecting whether a household has any current or past migrants, and (2) we included migration as a count variable reflecting how many migrants per household were sent abroad.

Socioeconomic and regional factors affect potential migrants' abilities to overcome access barriers to migrate, and hence, their potential earnings abroad and remittances (see chapter 2). It is plausible that because migration is not randomly allocated among households, certain factors, including the number of dependents in the household (e.g., children, elderly, and disabled), the number of working adults, household wealth, assets indices, urbanicity, education of adult members, and domestic employment status may all affect whether or not a household member is able to migrate (as discussed in Chapter 2). Additionally, these factors affect the outcome of interest - whether or not households spend money on healthcare. Each of these variables may confound the effect of migration on health

${ }^{61}$ See Box 1 at the end of the chapter for a full description of quasi-random sampling. 
expenditures as well as have a direct effect on health expenditures. For example, a higher number of dependent elderly individuals living in a household may prompt working adults to search for labour opportunities abroad, and these individuals may themselves require more health care, thereby increasing demand for - and associated spending on - health care. Because each of these variables may have such an effect on both the outcome of interest and the key explanatory variable, it is important to take these variables into account in our analysis.

\subsection{Methods}

Several econometric challenges previously discussed, including selection bias and omitted variable bias, need to be addressed. We estimate several models to test the relationship between migrant sending and non-sending household's health expenditures, controlling for a series of the aforementioned covariates. We were interested in testing differences between migrant sending and non-migrant households in terms of whether households had any health expenditures as well as the magnitude of health expenditures among households reporting any spending on health.

Financial data (e.g., expenditures and wealth) lead to questions about whether censoring and truncation exist and to what extent these affect estimation of effect size and significance. We are usually most concerned about censoring and truncation with respect to the main outcome variable. Censoring refers to observations that are included in the dataset as censored values (coded as zero, for example) despite the fact that other "real, non-zero" values for those data exist in reality. Many datasets censor wealth at zero, despite the fact that some people record negative earnings in financially difficult years; this would be an example of left censoring. Some datasets are subject to right-censoring; for example, some surveys "cut off" income measurement at certain values because some people would prefer not to report extraordinarily large earnings. Truncation, on the other hand, refers to data missing from the dataset that may bias our estimates and conclusions for certain populations. An example of right truncation would be a cohort study enrolling pregnant women at their first prenatal visit; women who had miscarriages or other pregnancy losses prior to a first prenatal visit would not be included in the study and would their data would thus be truncated. Censoring is usually more of a concern in econometric analyses, because it is often impossible to know anything about truncated data, i.e., those observations or individuals for which we have no data. Tobit model specifications are often used to deal with these problems. They are effectively hybrid logistic/OLS models that assume a certain distribution (normal distribution) of the censored dependent variable. 
In our data, while it is possible that truncation exists (entire families who migrate are not available for sampling - left truncation), it is difficult to think of a reason why left or right censoring would be a serious problem. With respect to left censoring, negative health expenditures seem to be an anomaly. The use of a tobit model in the context of this paper - using self-reported health expenditures - does not empirically make sense. Logically there are a large number of zero values recorded for health expenditures (if people are not ill, they do not need to spend money on health are). The data base also lacks good health status data. It is, therefore, necessary to consider models that would take account of variation between those people recording some health expenditures (non-zero values) and those recording no out-of-pocket health expenditures. These questions and concerns about specification and the endogeneity of migration led us to consider three alternate empirical approaches; estimation of a so-called "two-part" model, estimation of a Heckman selection model and an Instrumental Variable estimation.

A two-part model in this context is defined as two separate models that answer two different, but related research questions. The first part is a probit estimation modeling the effect of migration on a binary outcome variable (whether or not a household reported any out-of-pocket healthcare expenditure). The second part is an OLS estimation modeling the effect of migration on a continuous outcome variable (how much out-of-pocket healthcare expenditures are reported by the household), conditional on having reported some healthcare expenditure. This approach deals with the large number of zero values often recorded in selfreported health expenditure data by taking into account the fact that the factors that predict any expenditures could be different from those that predict the level of health spending. Particularly, in resource-poor settings, many people may report no healthcare spending, and they will likely be different from the population reporting health expenditure; therefore any model that did not take appropriately account of zero values would be biased. The general probit model is estimated as follows:

\section{$\operatorname{Pr}\left(H E_{h}\right)=\alpha+\beta_{1} M H_{h}+\beta_{2} U_{h}+\beta_{3} C D_{h}+\beta_{4} E D_{h}+\beta_{5} H S_{h}+\beta_{6} H A_{h}+\beta_{7}$ $H E_{h}+\beta_{8} E_{h}+\varepsilon_{h}$,}

where

$H E=$ health spending per household; $1=$ yes; $0=$ no;

$\boldsymbol{M H}=$ household with migrant; migrant household; $1=$ yes; $0=$ no;

$\boldsymbol{U}=$ urban household; $1=$ yes; $0=$ no;

$C D=$ ratio of children in the household to the total number of persons in the household 
$E D=$ ratio of elderly dependents in the household to the total number of persons in the household

$\boldsymbol{H} \boldsymbol{S}$ = a binary indicator (yes/no) of whether the household had savings of value greater than US $\$ 500$

$\boldsymbol{H} \boldsymbol{A}=$ weighted index of household-owned assets, as detailed by Morris,

Carletto, Haddinott, \& Christiaensen (1999)

$H E$ is a set of categorical dummy variables reflecting the highest level of education attained by the household head (primary, secondary, tertiary, and university)

$E=$ that includes members of the household employed abroad

The general OLS model is estimated as follows:

$H E_{h}=\alpha+\beta_{1} M H_{h}+\beta_{2} U_{h}+\beta_{3} C D_{h}+\beta_{4} E D_{h}+\beta_{5} H S_{h}+\beta_{6} H A s_{h}+\beta_{7} H E_{h}+$ $\beta_{8} E_{h}+\varepsilon \mathrm{h}$,

where

$H E=$ health expenditure of household among those households who spent $>\$ 0$ on healthcare;

$\mathbf{M H}=$ household with migrant; migrant household; 1 = yes; 0 = no;

$\boldsymbol{U}=$ urban household; $1=$ yes; $0=$ no;

$C D=$ ratio of children in the household to the total number of persons in the household

$E D=$ ratio of elderly dependents in the household to the total number of persons in the household

$H S$ = a binary indicator (yes/no) of whether the household had savings of value greater than US $\$ 500$

$\boldsymbol{H} \boldsymbol{A}=$ weighted index of household-owned assets, as detailed by Morris,

Carletto, Haddinott, \& Christiaensen (1999)

$H E$ is a set of categorical dummy variables reflecting the highest level of

education attained by the household head (primary, secondary, tertiary,

and university)

$E=$ that includes members of the household employed abroad

We also use an instrumental variable approach. Several previous studies have used migration prevalence from the surrounding community as an instrument for migration status. If the explanatory variable of interest is truly endogenous, a good instrument has two main criteria: (1) the instrument should be significantly predictive of the suspected endogenous variable and (2) the instrument should be 
validly excluded from the main equation, that is, the instrument should not be directly related to the outcome of interest (McKenzie \& Sasin, 2007). In our study, we believe migration prevalence in the sending community in Moldova has a strong effect on whether or not individual households decide to send workers abroad. Particularly, if sending communities' migrants tend to end up in the same host country, there may be especially strong ties, better information exchange, and more motivation to migrate when an existing network has experience with and understanding of such an experience (see chapter 2). We tested the validity of the instrument by assessing its predictive value on migration-sending status of households.

In terms of the second criterion of a good instrument, theoretically, it would seem that health expenditures are likely to be uncorrelated with the migrant community network on the sending end. It is however possible, as Mansuri suggests (2006), that migration prevalence rates as an instrument for migration motivation and opportunity could be influenced by unobserved community-level characteristics, including availability of, access to and quality of local health care services. In the presence of more than one instrument, one can test the exclusion validity of the inferior instrument. That is, under the assumption that one instrument is truly a valid instrument (good predictor and validly excluded from the main equation), we can test whether other instruments are unrelated to the outcome of interest. In our case, however, because we only have access to one reasonably valid instrument in the data available, we cannot test the exclusion validity of that instrument. Recognizing that other authors have questioned the use of community migration prevalence as an instrument for migration and in the absence of other good instrumental variables, we assume community migration network is validly excluded from the main equation and thus is an appropriate and valid instrument in this analysis.

We present results from the two-part probit and OLS estimation, an IV-probit and an IV-OLS estimation and Heckman selection estimation, using two alternate specifications of the main independent variable (any migrant in household and number of migrants in household) and two alternate specifications of the outcome of interest (absolute health expenditure per capita and the ratio of total household health expenditure to total household spending per capita). 


\subsection{Results}

Descriptive statistics are provided in Table 6.1 below. Of the households included in the survey, $19 \%$ overall were migrant-sending households. The total amount per capita spent on healthcare in the bivariate analyses varied significantly by migrant sending status with non-migrant sending households reporting higher health-related spending overall.

Table 6.1 Descriptive statistics among sampled households (from CBSAXA survey)

\begin{tabular}{|c|c|c|c|}
\hline Variable & $\begin{array}{c}\text { Non-migrant } \\
\text { sending } \\
\text { households } \\
\text { Mean or Percent }\end{array}$ & $\begin{array}{l}\text { Migrant sending } \\
\text { households }\end{array}$ & $\begin{array}{c}\text { Total } \\
\text { Mean or } \\
\text { Percent }\end{array}$ \\
\hline $\begin{array}{l}\text { Health expenditure per } \\
\text { capita (in lei) }\end{array}$ & $60.16^{* * *}$ & $42.88^{* * *}$ & 56.90 \\
\hline Migrant status (yes/no) & $0.0 \%$ & $100 \%$ & $19 \%$ \\
\hline Urban residence (yes/no) & $40 \% * * *$ & $30 \% * * *$ & $38 \%$ \\
\hline $\begin{array}{l}\text { Child dependency ratio } \\
\text { (\#child/\#household) }\end{array}$ & $0.51^{* * *}$ & $0.99^{* * *}$ & 0.6 \\
\hline $\begin{array}{l}\text { Elderly dependency ratio } \\
\text { (\#elderly/\#household) }\end{array}$ & $0.26^{* * *}$ & $0.15^{* * *}$ & 0.24 \\
\hline $\begin{array}{l}\text { Savings indicator (>500lei } \\
\text { saved; yes/no) }\end{array}$ & $11 \% * * *$ & $27 \% * * *$ & $14 \%$ \\
\hline $\begin{array}{l}\text { Asset index score } \\
\text { Highest education attained } \\
\text { by household head: }\end{array}$ & $59.20^{* * *}$ & $94.77^{* * *}$ & 65.88 \\
\hline Primary education & $20 \% * * *$ & $5 \% * * *$ & $18 \%$ \\
\hline Secondary education & $32 \% * *$ & $36 \% * *$ & $32 \%$ \\
\hline Tertiary education & $30 \% * * *$ & $45 \% * * *$ & $33 \%$ \\
\hline University degree & $18 \% * * *$ & $14 \% * * *$ & $17 \%$ \\
\hline $\begin{array}{l}\text { Head of household } \\
\text { formally employed }\end{array}$ & $10 \%$ & $11 \%$ & $10 \%$ \\
\hline $\begin{array}{l}\text { Community migration } \\
\text { network measure }\end{array}$ & $0.06^{* * *}$ & $0.09 * * *$ & 0.07 \\
\hline
\end{tabular}


There were also significant differences between migrant sending and non-migrant sending households with respect to urban residency, with a greater percentage of non-migrant sending households reporting living in urban areas. Migrant sending households tended to have a higher child dependency ratio, whereas non-migrant sending households tended to have a higher elderly dependency ratio. Financially, households sending migrants abroad were wealthier in terms of household savings accumulated and had more assets, according to the weighted asset index score. Generally, heads of migrant sending households were better educated compared to non-migrant sending households where $20 \%$ had less than or equal to a primary school education. Employment status for heads of households did not significantly vary by migrant sending status.

In terms of multivariate results, we first estimated the effect of migration on having any health expenditure (binary variable - yes/no). As shown in Table 6.2 below, probit estimation of the effect of migration status (binary variable - any migrant in household) indicated that on average, migrant sending households had a significantly lower likelihood of reporting any health spending during the time period $(\mathrm{p}=0.003)$. Additionally, on average, living in an urban area, having a higher childhood dependency ratio, having more assets, and living in a household with a formally employed head of household were significantly negatively correlated with reporting any healthcare spending. Having a higher elderly dependency ratio and having higher education were associated with greater likelihood of having any healthcare expenditure, adjusting for covariates. IVprobit estimation using community migrant network as an instrument yielded quite different results, suggesting that as anticipated, endogeneity and selection issues may be biasing probit results. 


\begin{tabular}{|c|c|c|c|c|}
\hline $\begin{array}{l}\text { Dependent Variable: Any } \\
\text { health exp (yes/no) }\end{array}$ & Model 1: PR & BIT & 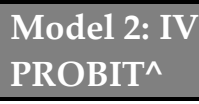 & \\
\hline Independent Variables & $\begin{array}{l}\text { Marg. } \\
\text { Effect }\end{array}$ & SE & $\begin{array}{l}\text { Marg. } \\
\text { Effect } ~\end{array}$ & SE \\
\hline Migrant status (yes/no) & $-0.056^{* *}$ & 0.019 & $-1.44^{* *}$ & 0.48 \\
\hline Urban residence (yes/no) & $-0.059^{* * *}$ & 0.015 & $-0.21^{* * *}$ & 0.046 \\
\hline $\begin{array}{l}\text { Child dependency ratio } \\
\text { (\#child/\#household) }\end{array}$ & $-0.032^{* * *}$ & 0.008 & -0.016 & 0.042 \\
\hline $\begin{array}{l}\text { Elderly dependency ratio } \\
\text { (\#elderly/\#household) }\end{array}$ & $0.026^{*}$ & 0.012 & 0.05 & 0.039 \\
\hline $\begin{array}{l}\text { Savings indicator (>500lei } \\
\text { saved; yes/no) }\end{array}$ & -0.028 & 0.021 & 0.073 & 0.089 \\
\hline $\begin{array}{l}\text { Asset index score } \\
\text { Highest education attained } \\
\text { by household head: }\end{array}$ & $-0.00018^{* *}$ & 0.000062 & -0.00024 & 0.00023 \\
\hline Primary education & Reference & & Reference & \\
\hline Secondary education & -0.009 & 0.022 & 0.042 & 0.069 \\
\hline Tertiary education & $0.048^{*}$ & 0.022 & $0.24^{* * *}$ & 0.072 \\
\hline University degree & $0.054^{*}$ & 0.026 & $0.19^{*}$ & 0.074 \\
\hline $\begin{array}{l}\text { Head of household formally } \\
\text { employed }\end{array}$ & -0.0024 & 0.024 & $0.563^{*}$ & 0.23 \\
\hline Constant & $0.25^{* * *}$ & 0.017 & $\mathrm{~N} / \mathrm{A}$ & $\mathrm{N} / \mathrm{A}$ \\
\hline
\end{tabular}

$\mathrm{N}=3810$

${ }^{*}$ significant at $10 \%$; ${ }^{* *}$ significant at $5 \%$; ***

significant at $1 \%$

$\wedge$ Instrument $=$ Community

migrant network

$\sim$ Marginal effect evaluated using probality

of averages method

Ordinary least squares multivariate models estimate of the effect of migration status (binary variable - any migrant in household) within the sub-sample of households reporting any expenditure $(\mathrm{N}=2810)$. The results presented in Table 6.3 below demonstrate that among those reporting some healthcare spending, there 
were no significant differences by migration status (binary variable - yes/no). However, education was a significant positive predictor of health expenditure in all levels of higher education comparead to primary school education. Additionally, child and elderly dependency were important predictors of amount of health spending. A higher child dependency ratio corresponded to lower overall health spending $(p<0.0001)$, whereas a higher elderly dependency ratio corresponded to higher overall health spending $(\mathrm{p}<0.0001)$ (both effects in the direction as predicted by Grossman's theory (Grossman, 1972).

\section{Table 6.3: OLS and IV Two-stage least squares estimation results for predictors of amount of health expenditure, among households reporting any health expenditure}

\begin{tabular}{|c|c|c|c|c|}
\hline $\begin{array}{l}\text { Dependent Variable: Health } \\
\text { expenditure per capita }\end{array}$ & \multicolumn{2}{|c|}{$\begin{array}{l}\text { Model 1: OLS in } \\
\text { the sub-sample }\end{array}$} & \multicolumn{2}{|c|}{$\begin{array}{l}\text { Model 2: IV 2SLS } \\
\text { in the sub-sample^ }\end{array}$} \\
\hline Independent Variables & $\begin{array}{c}\text { Marginal } \\
\text { Effect }\end{array}$ & SE & $\begin{array}{c}\text { Marginal } \\
\text { Effect } ~\end{array}$ & SE \\
\hline Migrant status (yes/no) & -7.97 & 5.19 & -92.58 & 60.52 \\
\hline Urban residence (yes/no) & -5.28 & 4.13 & $-9.17^{*}$ & 4.75 \\
\hline $\begin{array}{l}\text { Child dependency ratio } \\
\text { (\#child/\#household) }\end{array}$ & $-20.42^{* * *}$ & 2.24 & $-15.08^{* *}$ & 4.52 \\
\hline $\begin{array}{l}\text { Elderly dependency ratio } \\
\text { (\#elderly/\#household) }\end{array}$ & $17.88^{* * *}$ & 4.24 & $16.31^{* * *}$ & 4.47 \\
\hline $\begin{array}{l}\text { Savings indicator (>500lei saved; } \\
\text { yes/no) }\end{array}$ & 0.72 & 6.37 & 11.81 & 9.92 \\
\hline Asset index score & 0.0033 & 0.015 & 0.012 & 0.027 \\
\hline $\begin{array}{l}\text { Highest education attained } \\
\text { by household head: }\end{array}$ & & & & \\
\hline Primary education & Reference & & Reference & \\
\hline Secondary education & $18.60^{* *}$ & 5.97 & $23.64^{* * *}$ & 6.30 \\
\hline Tertiary education & $11.81^{* *}$ & 4.28 & $20.29^{* *}$ & 7.22 \\
\hline University degree & 10.84 & 0.072 & $12.61^{*}$ & 6.32 \\
\hline $\begin{array}{l}\text { Head of household formally } \\
\text { employed }\end{array}$ & -6.78 & 7.41 & 30.30 & 27.03 \\
\hline Constant & $76.47^{* * *}$ & 3.36 & $76.50^{* * *}$ & 3.43 \\
\hline
\end{tabular}


Significance and direction of results between OLS regression and two-stage least squares regression were generally similar, with the notable exceptions of urban residence and university degree becoming statistically significant when an IVapproach was used, with community migrant network as an instrument. In both the OLS and the two-stage least squares regressions, household migrant status was not significantly predictive of the total amount of health expenditure per capita.

We also estimated two-part probit and OLS regressions using different specifications for the dependent and independent variable (results not shown). We examined whether overall results changed when health expenditure was coded as: (1) whether or not households had any health expenditures (binary variable), (2) absolute household health expenditure per capita (continuous variable with no upper bound), and (3) the ratio of household health expenditure per capita over total household expenditure per capita (0-1 continuous variable). We also considered whether results changed when our main independent variable, migrant sending status, was measured as: (1) including migration as a 0 or 1 variable reflecting whether a household has any current or past migrants, and (2) including migration as a count variable reflecting how many migrants per household were sent abroad. Results did not vary widely across models; thus, we reported the most straightforward regressions here.

\subsection{Conclusion}

Quite surprisingly, migrant sending households in Moldova had a lower likelihood of reporting any healthcare spending, compared to non-migrant sending households. Moreover, there are no significant differences in terms of total amount spent by migrant status, among those households reporting any healthcare expenditure. Education, ratio of child and elderly dependents living in the household, urbanicity, and household assets were found to be strong predictors of having any healthcare expenditure, controlling for other covariates. Equally, education, ratio of child- and elderly dependents, and urbanicity were the only significant predictors of the magnitude of healthcare expenditures observed in this study. We argue that two-part estimation (probit and OLS) and two-part IV estimation (IV probit estimation followed by two-stage least squares among the sub-sample reporting any health expenditure) are the best empirical approaches to answer the research question.

These results are somewhat surprising and may be counter-intuitive. One may expect that remittances, and thus the availability of better and more funding, would lead to more frequent and higher health care expenditures. The results do not confirm these expectations; migrant sending households may report lower 
likelihood of having any health expenditure for a number of reasons; due to (1) better health status, (2) perceived lack of need of healthcare, (3) greater elasticity in decision-making about health spending, (4) less willingness or capability to pay out-of-pocket for health care, or (5) less motivation to invest in health. Any number of these possibilities is plausible. Particularly, given the descriptive differences between migrant sending and non-migrant sending households, the issue of selection bias is particularly poignant. For example, we know that migrant-sending households in this sample were wealthier, more educated, more likely to live in non-urban areas, and more likely to have more migrants within their community network; these factors surely affect ability, motivation, and confidence with respect to economic migration. Households who send migrant workers abroad may also be healthier in general and thus need less health care; the data did not allow us to take this factor empirically into consideration since we were unable to measure health status in this survey. Although we have tried to account for selection by migration status by using an instrumental variable approach, IV estimation has limited usefulness when the exogeneity of the instrument cannot be tested. Because we only have one instrument as opposed to being "overidentified", we cannot test the exogeneity of community migration network. Rather, we must rely on theory to argue that this instrument is validly excluded from the main equation, that is, that community migration network is not related to health spending. Although use of community migration prevalence has previously been used in the migration literature as a suitable instrument, it is conceivable that in some cases, general health, demand for healthcare, and costs of/spending related to healthcare may prompt some people in the community to migrate (for example, if a household member's healthcare expenses exhaust household savings and assets and require a healthier member of the household to work abroad and send remittances back to the household to help pay for healthcare). At least two instruments should ideally be identified to test exogeneity, and one of these must be assumed to be a "good instrument" at baseline. With limited data available at the household level, finding two good instruments, however, is considerably difficult.

The relationships between education, dependency ratios, and urbanicity were related to healthcare expenditure in expected ways. Particularly, with respect to dependency, we would expect that households with greater elderly dependency would likely have greater need for health services because elderly individuals typically have worse overall health status compared to the general population. Similarly, children tend to be healthier than the general population, so we would expect that a higher child dependency ratio would correspond with lower overall health expenditure. 
There are several limitations to this study. First, because we use cross-sectional data, causation cannot be inferred; we cannot surmise about the directionality of the association between migration and health spending with confidence. As has been previously noted in the literature, an absence of high quality migration data makes studies of this nature difficult. Longitudinal studies with household followup over a lengthy period, for example, ten years, would be an excellent contribution to the dearth of available data for analyses of interest to the Moldovan government and to economic and development interest groups. With longitudinal data, we could use fixed effects estimation to control for unobserved, timeinvariant community/household characteristics that otherwise might bias study results. Additionally, improving the number and validity of instrumental variables would be useful. Truly randomly assigned instruments are best. As such, taking advantage of natural experiments that exist, including government visa lotteries, may be an ideal approach to dealing with econometric concerns of endogeneity. As social welfare and health policy researchers, identifying such opportunities proves to be a challenge but can provide an invaluable unbiased and rigorous examination of migration effects on human welfare. Finally, there are several important unobserved variables that were unavailable in the dataset, the most important of which may be health status. Knowing household health status could provide a wealth of information related to intrinsic demand for healthcare, willingness to pay for necessary versus auxiliary health services, and agestructured health-related need. Other variables that would likely be important in quantifying the relationship between health spending and migration include: amount and frequency of remittances sent to the household, house structure/living environment, access to and quality of local health care in migrant sending communities, the purchase of private health insurance and community socioeconomic status. 


\subsection{References}

Acosta, P. (2006). "Labor Supply, School Attendance, and Remittances from International Migration: The Case of El Salvador." World Bank Policy Research Working Paper 3903.

Acosta, P. (2007). Entrepreneurship, Labor Markets, and International Remittances: Evidence from El Salvador. International Migration, Economic Development and Policy. Ç. Özden and M. Schiff. Washington, D.C., World Bank.

Adams, R. H. (2005). "Remittances, Household Expenditure and Investment in Guatemala." World Bank Policy Research Working Paper 3532.

Beckman, A., J. Merlo, et al. (2004). "Country of birth, socioeconomic position, and healthcare expenditure: a multilevel analysis of Malmö, Sweden " Journal of Epidemiology and Community Health 58: 145-49.

Burns, A. D. and A. C. Harrison (2007). "Costs of investigating and managing nonresidents with possible tuberculosis: New Zealand experience of an international problem." Respirology 12: 262-266.

Chami, R., S. Jahjah, et al. (2003). "Are Immigrant Remittance Flows a Source of Capital for Development." IMF Working Paper 03/189.

Cots, F., X. Castells, et al. (2008). "Impact of immigration on the cost of emergency visits in Barcelona." BMC Health Services Research 7(9).

Cox-Edwards, A. and M. Ureta (2003). "International Migration, Remittances, and Schooling: Evidence from El Salvador." Journal of Development Economics 72: 429-461.

DeMaria, A. N. (2005). "Immigration policy and health care." Journal of the American College of Cardiology 15(10): 1729-1730.

Folland, S., A. C. Goodman, et al. (2004). Chapter 6: Demand for Health Capital. The Economics of Health and Healht Care 4th Edition. S. Folland, A. C. Goodman and M. Stano. Upper Saddle River, NJ, Pearson Prentice Hall.

Folland, S., A. C. Goodman, et al. (2004). Chapter 8:Consumer Choice and Demand. The Economics of Health and Health Care 4th Edition. S. Folland, A. C. Goodman and M. Stano. Upper Saddle River, NJ, Pearson Prentice Hall.

Frank, R. and R. A. Hummer (2002). "The other side of the paradox: the risk of low birth weight among infants of migrant and nonmigrant households within Mexico " International Migration Review 36(3): 746-765.

Gerdtham, U.-G. and M. Johannesson (1999). "New Estimates of the Demand for Health: Results Based on a Categorical Health Measure and Swedish Micro Data." Social Science and Medicine 49: 1325-1332. 
Grossman, M. (1972). "On the Concept of Health Capital and the Demand for Health." The Journal of Political Economy 80(2): 223-255.

Hanson, G. and C. Woodruff (2003). "Emigration and Educational Attainment in Mexico." Working Paper University of California, San Diego.

Hildebrandt, N. and D. McKenzie (2005). "The Effects of Migration on Child Health in Mexico." Journal of Latin American and Caribbean Economic Association.

Kanaiaupuni, S. M. and K. M. Donato (1999). "Migradollars and Mortality: The Effects of Migration on Infant Survival in Mexico " Demography 36(3): 339353.

López-Córdova, J. E. (2005). "Globalization, Migration and Development: The Role of Mexican Migrant Remittances." Journal of Latin American and Caribbean Economic Association.

López-Córdova, J. E. and A. Olmedo (2007). "International Migration, Remittances and Development: An Overview." Integration and Trade 27.

Lücke, M., T. O. Mahamoud, et al. (2007). Patterns and Trends of Migration and Remittances in Moldova. International Organization for Migration. Chisinau.

Mansuri, G. (2006). "Migration, School Attainment and Child Labor: Evidence from Rural Pakistan." World Bank Policy Research Working Paper 3945.

Mansuri, G. (2006). "Migration, Sex Bias, and Child Growth in Rural Pakistan." World Bank Policy Research Working Paper 3946.

McKenzie, D. (2005). Beyond Remittances: The Effects of Migration on Mexican Households. International Migration, Remittances and the Brain Drain. Ç. Özden and M. Schiff. Washington, D.C., World Bank.

McKenzie, D., J. Gibson, et al. (2006). "How Important Is Selection? Experimental vs. Non-Experimental Measures of the Income Gains from Migration." IZA Discussion Papers 2087.

McKenzie, D. and M. J. Sasin (2007). "Migration, Remittances, Poverty, and Human Capital: Conceptual and empirical challenges." World Bank Policy Research Working Paper 4272.

Miclutia, I., V. Junjan, et al. (2007). "Migration, mental health, and costs consequences in Romania." Journal of Mental Health Policy and Economics 10(1): 43-50.

Morris, S., C. Carletto, et al. (1999). "Validity of Rapid Estimates of Household Wealth and Income for Health Surveys in Rural Africa." FCND Discussion Paper 72 .

Munshi, K. (2003). "Networks in the Modern Economy: Mexican Migrants in the United States Labor Market." Quarterly Journal of Economics 118(2): 549597.

Ratha, D. and Z. Xu (2008). Migration and Remittances Factbook 2008. Washington, D.C., The World Bank. 
Siegel, M. and M. Lücke (2008). "What Determines the Choice of Transfer Channel for Migrant Remittances? The Case of Moldova." Kiel Institute for World Economy Working Paper.

Taylor, J. E. and J. Mora (2006). "Does Migration Reshape Expenditure in Rural Households? Evidence from Mexico." World Bank Policy Research Working Paper 3842.

Yang, D. (2004). "International Migration, Human Capital, and Entrepreneurship: Evidence from Philippine Migrants' Exchange Rate Shocks." University of Michigan Working Paper.

Yang, D. and C. A. Martinez (2006). Remittances and Poverty in Migrants' Home Areas: Evidence from the Philippines. International Migration, Remittances and the Brain Drain. Ç. Özden and M. Schiff. Washington, D.C., World Bank. 


\section{Box 1: Procedure used in quasi-random sampling \\ (CBSAXA consultancy, 2006)}

(1) Determine the total number of households to be interviewed (henceforth: "questionnaires") based on the required sampling error. For the 2006 survey: three percent sampling error for the share of households with migrants nationwide; 3940 households.

(2) Allocate questionnaires to the four regional strata (rural areas, towns, Balti, urban parts of Chisinau) according to their share in total population according to 2004 population census.

(3) For rural areas, allocate questionnaires (according to rural population share) to each of the 12 economic areas corresponding to the former judets.

(4) Within each judet, establish a list of small villages $(<1000$ population) and large villages ( $>1000$ population). Allocate questionnaires to each list according to population shares of small and large villages in given judet.

(5) Every village is a potential primary sampling unit. Separately determine the number of small villages and large villages to be selected in each judet such that every selected small village is allocated 10 questionnaires and every large village 15 questionnaires.

(6) From each list of villages for every judet, select the the appropriate number of villages randomly (by reference to a list of random numbers).

(7) Within each selected small (large) village, the coordinator assigns two streets (three streets) randomly according to a map of the village or other relevant criteria (e.g. take the street with the school and the first parallel street, etc.).

(8) Interviewers select the houses to be interviewed according to the statistical step method: count the number of households in the relevant street leaving out nonresidential buildings; divide by number of interviews in street, typically five, to obtain the step size s; interview every s-th house in the given street; return three times during the interview day if no one is at home, with more than two hours between return visits; if still no response, create new statistical step (based on number of questionnaires plus 1) and add an extra house at the end of the street.

(9) For towns, allocate number of questionnaires within each judet according to population share in this stratum; select towns randomly such that minimum number of questionnaires is 15 per town (according to population share if this results in a higher number than 15). In the 2006 survey, all towns in Moldova were in fact selected.

(10) Determine number of streets to be sampled such that five questionnaires are allocated per street; select streets randomly from phonebook.

(11) Within every street, use statistical step method. For single-level houses, same procedure as in villages. For every block of flats, only one questionnaire.

(12) 2 largest cities (Chisinau/Balti): determine number of questionnaires in each raion/sector according to population; select streets such that there are five questionnaires per street (in fact, all streets were selected in the 2006 survey). In applying statistical step method, count each entrance (korpus) in a block of flats as one unit. Within every korpus, follow predetermined rule for choosing apartment (e.g. third floor, right-hand side, second apartment if more than one). 


\section{Chapter 7: Concluding Remarks}

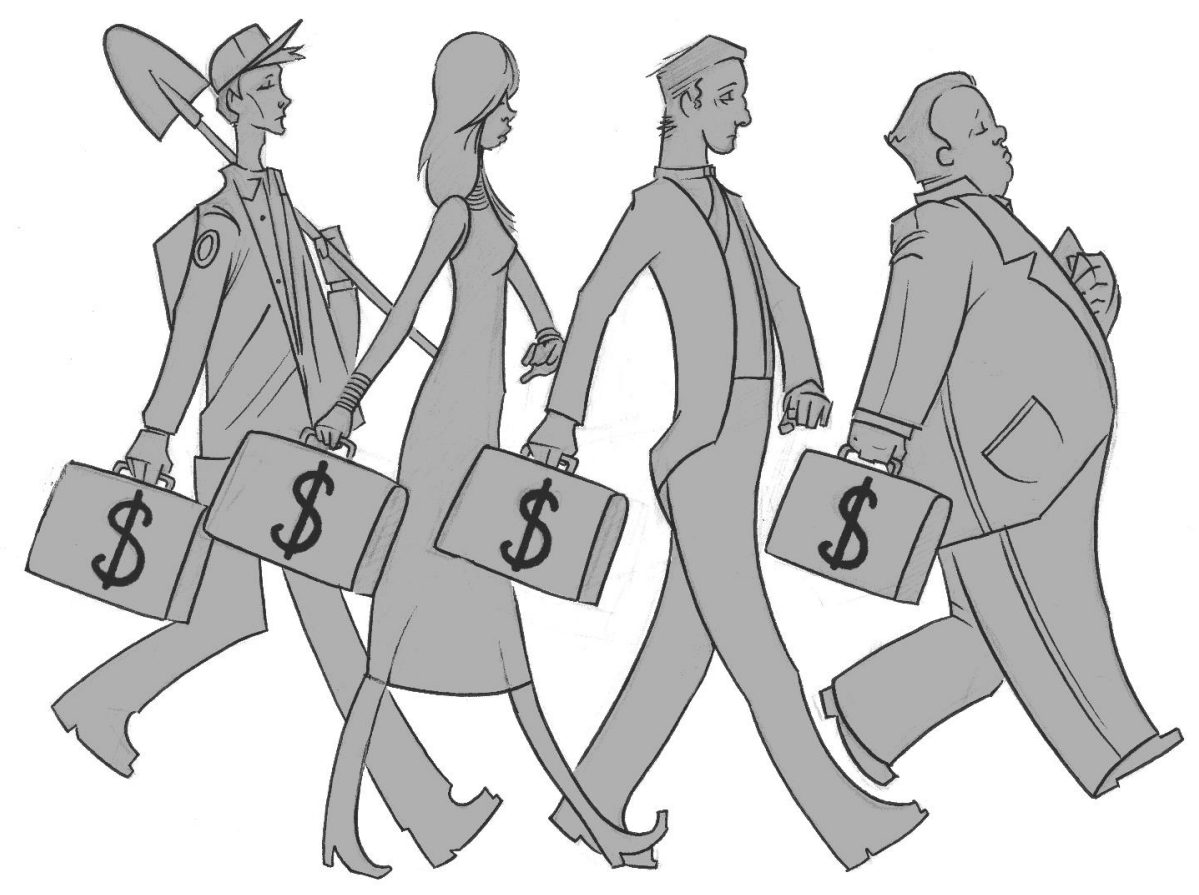




\subsection{Summary of main findings}

\subsubsection{Migration decision}

Despite the potential gains that migration can offer to many people across the world, relatively few individuals actually migrate. This limited propensity to migrate is influenced by both a preference for home and the ability to move. Consumption smoothing behaviour or livelihood strategies combined with a Welfare Pentagon framework-mapping the institutions and assets (capital) that are needed to use the smoothing strategies-can explain why certain people migrate.

Some people are actually restrained from migration by their age (too young, too old), their health, or their care responsibilities for the old, the young and the ill. It has been argued that the migration behaviour of people with a free will to migrate is constrained by the lack of access to the Welfare Pentagon channels, resources and assets that are necessary for considering and actually implementing migration as a livelihood strategy. The differences in the degree of access to the Welfare Pentagon channels and the related assets in both the sending country Welfare Pentagon and the receiving country Welfare Pentagon are the crucial variables in explaining why some people migrate and others do not. The sunk costs of being rooted in the Welfare Pentagon of the sending country explain the preference of most people for staying in the country they live in.

Households that lack possibilities in the home country (due to, for instance, low education or limited access to labour market) would gain from migration. This very lack of access to some institutions of the Welfare Pentagon, however, also restrains the households from migrating. The very poor and unattached households are stuck in a poverty trap in which their advancement is just as pivotally constrained at home as abroad. The development prospects for these groups in society seem bleak, but for some individuals, the lack of access to certain institutions (markets and families) of the Welfare Pentagon can be compensated by access to other institutions, such as public institutions or social networks that give information about migration. It has been posited that households need access to different institutions both to prosper at home and to migrate. These institutions overlap and government intervention could strengthen those institutions that allow people to make a free choice between remaining in the country of origin or migrating. In the end, however, it is ultimately the individual's choice to decide whether to break the strings and migrate or to stay at home.

There are three main mechanisms that influence the decision to migrate: (1) the individual (household) is constrained in its ability to generate income and to 
smooth consumption below a level that it deems necessary to fulfill its needs in the sending country; (2) the individual (household) has access to the Welfare Pentagon institutions and assets that allows it to consider migration and to overcome the costs related to leaving the sending country, and; (3)the individual (household) perceives adequate access to the Welfare Pentagon institutions and assets in the receiving country that will enable it to generate income and smooth consumption following migration. The combination of these mechanisms can explain why some (members of) households migrate while others do not.

The degree of embeddedness in the Welfare Pentagon of the receiving country and the related sunk costs will act as impediments to remigration while the degree of embeddedness in the home country Welfare Pentagon will act as an incentive to return. The net outcome of the two counteracting forces is an empirical question, and its answer depends on the public policies and economic prospects in both the receiving and the home country, as well as on the investment behavior of migrants in the sending and the receiving country. Policy makers who believe that controlling migration is a real possibility implicitly believe that public policy can change the incentives in all or some of the stages of the migration process. At the stage of the initial migration from the sending country, an optimistic policy maker envisioning selective migration into the receiving country assumes that public policy in the receiving country imposes appropriate incentives to encourage the migration of specific groups from the sending country, while discouraging unwanted groups with the proper disincentives. The equally-optimistic policy maker in the receiving country, wishing to stimulate return and circular migration assumes that the incentives can be set to stimulate people to emigrate out of the receiving country back to the home country. Whether this policy view is overoptimistic depends not only on the economic incentives offered to the migrants (including the relevant economic prosperity of the two countries involved $\left.{ }^{62}\right)$, but also on the relative degrees of embeddedness of the migrants in the four relevant welfare pentagons: the pentagon in the sending country prior to the initial migration, the pentagon in the receiving country at the time of the initial migration decision, the pentagon of the receiving country after the initial

\footnotetext{
${ }^{62}$ It should be noted that the theoretical framework can and should be studied in its dynamic properties. It is clear that over time, economies grow, and it is likely that the economy of some of the sending countries will catch up. This implies that economic growth prospects in the sending country may become relatively better than in the receiving country, thus providing an incentive for migrants to return. It is also clear that migrants' relative positions in the (income) distribution in the Welfare Pentagon institutions of the receiving countries gets better with the migrants' length of stay and integration position. This may act as a disincentive to re-migrate. On the other hand, however, higher income in the receiving country would mean an even higher relative position in the sending country after return, and this thus acts as incentive to move back to the country of origin. As stated above, the net effect of these forces is an empirical question that deserves further research.
} 
migration, and the pentagon of the home (sending) country at the time of the eventual re-migration decision.

\subsubsection{Remittance decision (in Albania and Moldova)}

One of the most central findings derived from the chapter on remittance decisions is that a great deal of care must be taken in interpreting migrants' motives to remit based upon empirical finds, many of which are reliant upon a small range of variables that can be interpreted in different ways. It is not possible to give a satisfying empirical answer to the question of the motives to remit. Not only do theories on the motivations to remit overlap, but the dichotomy of altruism versus self-interest in real-life remittance behaviour is not as straightforwardly expressed as it is in theory. The way in which motivations to remit are understood must be revisited and revised to incorporate the social context and the full complexity of factors influencing a migrant's decision to remit.

While it has been shown that migration and remittances are important for both Albania and Moldova, the two countries and their experiences differ in terms of the migration and remittance patterns. Men constitute the majority of migrants in both countries, and remittances are sent to all income groups. To investigate the different motives to remit more closely, three different econometric models were applied following assessment of the theoretical and empirical literature on the motivations to remit. While some evidence was found for some motivation, the analysis resulted in inconclusive results, which is very much in line with existing literature on the topic.

It is clear that the causes and patterns of migration in Albania and Moldova influence subsequent remittance behaviour. Geographical location, economic possibilities, and family situations determine where, for how long, and under what circumstances a migrant can migrate and send remittances. Migrating and remitting are, in many cases, joint decisions made on a household level, and to look exclusively at the motivations to remit biases the results and omits vital explanatory factors. Furthermore, it is necessary to differentiate between the desire and the capacity to remit.

\subsubsection{Remittance channels}

This dissertation dedicates two chapters to the remittance channel decision: one chapter focuses on the Moldovan situation from the remittance-receiving perspective while the other focuses on channel choice through study of the Netherlands as a remittance-sending country. Both chapters have enabled the formulation of recommendations for policies to enhance remittance sending through formal channels. From both chapters it becomes evident that the clearest 
ways to promote formal sending are by reducing costs, increasing access to channels, and supporting information dissemination on formal sending methods.

\subsubsection{The Moldovan experience}

The regression analysis conducted identified several important reasons why approximately one-half of the Moldovan migrants and their families in the sample do not use formal transfer channels. Migrants who primarily use informal services are more likely to be in high-income countries (mostly the EU), reside in the host country illegally, remain abroad for periods longer than one year, do not have a bank account, and are primarily concerned about the cost of the transfer (rather than speed, convenience, security, or familiarity with the method). Migrants who rely on personal transfers are more likely to be in CIS countries, remain abroad for less than one year, send remittances irregularly, and do consider cost of the transfer (rather than speed, convenience, or security of the service) as the primary deciding factor.

Some of these determinants suggest the presence of distortions that can potentially be reduced through appropriate policy measures. Other determinants reflect migration patterns such as seasonal or irregular migration that will likely cause some migrants to use personal transfers or informal services regardless of the wider institutional and policy environment. Policy interventions can thus be launched by addressing costs of money transfers, the treatment of irregular migrants in host countries, and the linkage between remittances and financial sector development.

Although fees for international money transfers have declined substantially in recent years, transfer costs continue to play a large role in the choice of the transfer channel. According to Sander et al. (2005), fees paid by Moldovan migrants varied widely between one and 20 percent of the total transfer amount, and in many cases, substantially lower fees were associated with the use of informal channels. As fees often include a fixed per-transaction component, smaller amounts incur a relatively higher fee. The IOM-CBS AXA survey reports the fees actually paid for the selected transfer channel but provides only limited information on the wider range of options that might be available to the particular migrant-recipient pair.

The recently-established World Bank database "Remittance Prices Worldwide" lists mid-2008 fees that include exchange rate premiums for many remittance corridors, including Russia to Moldova; this database does not report any other flows to Moldova, however. Fees for transfers from Italy and elsewhere in Western Europe to Eastern Europe may be broadly representative of the options available to Moldovan migrants, which enables further assessment of channel availability to Moldova. Typically, transfer fees from Western Europe to Moldova are much higher than fees from Russia to Moldova (five to 15 percent versus 1.5 to five 
percent). This observation may explain why informal channels are used widely from high-income countries to Moldova but not from CIS countries.

Furthermore, across corridors originating in Western Europe, the fee level seems to be lower if specialised service providers (for example, those active only in a particular region) compete with the established market leaders (Western Union and MoneyGram). Competition appears to be even more active in the market for transfers from Russia. Even though information in the World Bank database is not fully representative, the reported fee differences across providers within and across particular corridors with (presumably) similar cost structures are astonishing. These observations suggest that by fostering competition in high-cost locations, transfer fees could be reduced, and the recipients' welfare gains from remittances could thus be enhanced. Recent initiatives in several remittancesending countries to increase the transparency of fee structures and enhance competition are, therefore, highly appropriate.

Within Moldova the large number of active money transfer operators (MTOs) suggests that there is a fair degree of competition in the market for international transfers, which has helped to reduce transfer fees. MTOs are obligated to operate through commercial banks. While this rule makes it easier to offer other banking services to recipients of remittances and may thereby facilitate financial sector development, there is an inherent risk that it may limit competition in the market for international transfers.

That risk is enhanced by the fact that the commercial bank that controls more than half of the banking presence in the country (via branches, representative offices, and agencies) cooperates with only one MTO, while most other commercial banks cooperate with several. Presumably the restrictions on the independent conduct of international transactions by non-bank entities such as MTOs, or even credit unions, reflect a desire for tight prudential control in a country where financial markets are not yet mature and legal order is only emerging. This desire for close oversight should be balanced, however, against the need to enhance competition in the oligopolistic commercial banking sector and in the market for international transfers in particular.

The regression analysis has demonstrated that irregular residence status makes it less likely that migrants will use formal transfer channels. While it is now an established principle that financial institutions have to "know their customers", it is not clear that this should prevent institutions from serving irregular immigrants whose presence is nevertheless tolerated by host country authorities (to the point that many such migrants may qualify for legal residence after a few years in the host country). Regulations that allow irregular migrants to identify themselves using home-country documentation without fear of deportation may detract from the appeal of informal transfer services that are, by their very nature, less 
transparent than formal channels. This has been highly successful in the US and Mexico, where the upgrading of the Matrícula Consular de Alta Seguridad (MCAS) card as an official identity document issued by Mexican Consulates for their nationals living abroad has made the card a legitimate source of identification, even for undocumented migrants (Hernández-Coss, 2005).

Regarding the linkage between remittances and financial development, Rios-Avila and Schlarb (2008) show through an econometric analysis based on the 2006 IOMCBS AXA survey that remittances provide an incentive to use more banking services; in particular, households with migrants are significantly more likely to own a bank account. At the same time, the share of "banked" households (constituting 11 percent of all households) is much lower than the share of households that receive remittances. As remittances will often not be spent immediately, and many migrant households have considerable amounts of savings, there would appear to be a significant demand from households for more financial services, starting with current and savings accounts. The fact that money transfer operators in Moldova have to work exclusively through commercial banks should make it easier for banks to reach migrants and their families. As recipients must enter a bank to pick up their remittances, they become more familiar with the bank and are exposed to the marketing of banking services. While internationally comparable data are scarce, the limited information available (Claessens, 2006) suggests that in many developing and transition countries, the share of households using formal financial institutions is similarly low.

While more can and should be done to promote formal transfer services for remittances both in remittance-sending countries and in Moldova, the fact that just under half of all migrant-recipient pairs use formal channels represents an important achievement. In value terms, the market share of formal services is perhaps even higher because formal channels are more likely to be used for the transfer of higher payment amounts (a fact that is not fully reflected in the dataset because higher remittances in particular are under-reported). The wide-spread use of formal transfer services is mirrored by the financial deepening that has occurred in Moldova since 1999. Although the aftermath of the dissolution of the Soviet Union resulted in the liquidation of most Moldovans' savings and the level of financial literacy remains low, confidence in banks is returning. The ratio of bank account balances to GDP has quadrupled from 1999 to 2008, with especially strong increases for individual (rather than business) accounts. 


\subsubsection{The Dutch experience}

Following the investigation into remittance channel choice from the receivingcountry perspective, Chapter 5 examines the remittance channel decision from the remittance-sending country. This chapter considers the influence that other factors play in determining remittance channel choice, and it directs particular attention to immigrant integration (measured by both socio-economic and socio-cultural indicators), as integration may affect migrants' comfort level with and knowledge of formal remittance services (especially banks). The analysis does yield some evidence for the immigrant integration hypothesis, but the analysis confirms that immigrant integration is not the only factor in the remittance channel decision, as has been mentioned in the previous chapter on remittance channel choice. Integration, as measured here in a rank order, gives mixed results for affecting the decision to remit. Institutional factors and policies may play a larger role in the remittance channel decision than integration does. Turkey appears to be a particular case to this point. Turks remit to a large extent through banks in spite of the fact that they are one of the middle-integrated migrant groups in the Netherlands. This can be explained by the fact that they are mostly served by Turkish banks operating in the Netherlands. This finding implies that groups that are less integrated may still remit formally because the formal transfers are strongly embedded in their culture or society. There is also a Moroccan banking presence in the Netherlands, and the Moroccan Central Bank makes it attractive for Moroccans to use the formal banking system. Policies that promote migrantsending country involvement can increase the use of formal services, especially banks, and perhaps also facilitate inclusion of the "unbanked" in the sending country by engaging migrant families without bank accounts in formal financial systems linked to remittance receipt.

It is important to keep in mind that immigrant integration is only one of the factors that influence remittance channel choice. In countries where there is little or no formal infrastructure for sending money, formalized remitting is not an option, regardless of how integrated the group is in Dutch society. This is obvious in the case of Somalia. Political stability was a key factor in the decision to remit formally and was highly associated with MTO transfers. It is not entirely clear why this is the case, but it can be projected that this trend is due to market factors that make MTOs more responsive in high-risk environments than banks.

The overall findings of the relationship between immigrant integration and remittance channel choice lend some limited evidence to policy makers regarding means of increasing the use of formal remittance channels. The financial sector may be incentivized to promote migrant integration by the prospect of additional users and consumers of their services. Policy makers interested in the 
formalization of remittances may first need to consider enabling forces that promote formal remittance sending, such as trust of financial institutions and cultural competency. Thoughtful, culturally sensitive policies will also encourage use of formal channels. Ideally, a combination of policies that involve institutional investment, improvements in financial infrastructure and connectedness, and cultural outreach to vulnerable populations, including migrants, should be pursed by policy makers to encourage the abandonment of informal transfer channels.

\subsubsection{Migration and remittance effects}

In the last empirical chapter, one particular aspect of the effects of migration and remittances on households in Moldova (healthcare spending) is evaluated. Migrant-sending households in Moldova had a lower likelihood of reporting any healthcare spending than non-migrant-sending households. Among households reporting any healthcare expenditure, there were no significant differences observed in terms of total expenditure amount. When controlling for other covariates, education, ratio of child and elderly dependents living in the household, urban orientation, and household assets were strong predictors of the household having any healthcare expenditure. Education, ratio of child and elderly dependents, and urban orientation were the only significant predictors of the magnitude of healthcare expenditures observed in this study.

Migrant-sending households may report a lower likelihood of having any health expenditure for a number of reasons, namely: (1) general better health status of household members; (2) perceived lack of need of healthcare; (3) greater elasticity in decision-making about health spending; (4) less willingness or capability to pay out-of-pocket for health care, or; (5) less motivation to invest in health. Any combination of these possibilities is reasonable. Given the descriptive differences between migrant-sending and non-migrant-sending households, the issue of selection bias is particularly poignant. For example, it is known that migrantsending households in this sample were wealthier, more educated, more likely to live in non-urban areas, and more likely to have more migrants within their community networks; these factors surely affect ability, motivation, and confidence with respect to economic migration. Households that send migrant workers abroad may also be healthier in general, but this conclusion would be premature to draw as health status was not measured in this survey.

Education, dependency ratios, and urban orientation were related to healthcare expenditure in expected ways. For example, it would be expected that households with greater elderly dependency ratios would likely have greater need for health services because elderly individuals typically have worse overall health status 
compared to the general population. Similarly, children tend to be healthier than the general population, so it could be expected that a higher child dependency ratio would correspond with lower overall health expenditure.

\subsection{Next steps in research}

This dissertation deals with four main issues: the migration decision, the remittance decision, the remittance channel decision, and the effects of migration. In all of these areas, better data would be extremely useful: data collection and surveys are increasingly important for the future of migration and remittances research. Carling (2008) states that "the ideal [remittance] survey would be a very complex one, with multi-level information about potential senders and receivers...surveys should, to a greater extent, take into account the two-sidedness of determinants". In the last ten years, much more attention has been given to data collection for migration and remittances, but significant data gaps persist in these areas. Many countries neglect to collect sound data if they collect any data at all. Migration research would also benefit from mixed-method data collection approaches in which both quantitative and qualitative tools are used to yield rich and multilevel data. With the launch of new programs (such as NORFACE) and increased dedication of research money to migration and remittance data collection, the coming years will see many of the identified gaps in migration research breached, resulting in broader understanding of migration processes and the policy responses they inspire. In the next few years, the Maastricht Graduate School of Governance will collect rich migration and remittances data in at least five countries that will observe trends and characteristics from both sides of the migration process. The study will focus on the processes of migration and remittances, the rise of transnationalism, migrant investment, return migration, and highly-skilled migration trends, among other topics. The resulting data will help answer many of the open questions left lingering in this dissertation and other research.

\subsubsection{Migration}

In addition to broad data collection needs, the chapter on the migration decision with its discussion of the preliminary evidence for the Welfare Pentagon framework points to the needs for more in-depth research on the application of the Welfare Pentagon to the migration context. The empirics in the chapter are only exploratory, and more work needs to be done in testing the Welfare Pentagon hypothesis using identical datasets for different countries, including both the sending and receiving country. More work should also be done to investigate the role of policies in promoting or deterring migration in migration sending and receiving countries. More studies to examine the impact of government policies of 
migration decisions would be extremely helpful to policy makers, particularly for the highly-skilled, as many developed countries claim to want to attract this type of labour.

\subsubsection{Remittances}

There has been much research into why people send remittances, a great deal of which has focused on testing the theoretical motives to remit with empirical research. As was illustrated and argued in Chapter Three, the process of using empirical research to prove remittance motivation has thus far provided to be an extremely difficult prospect. More research should be focused on disaggregating motives in empirical research. More qualitative research should be used in this area to complement econometric analyses in uncovering the root causes for sending within specific communities. Economists are particularly susceptible to using only quantitative methods to conduct research, without acknowledging the role that qualitative methods can play in offering helpful and innovative insights before, during and after quantitative research.

\subsubsection{Remittance channels}

Little research has been conducted in the area of remittance channel choice, so any research that can be done, especially across countries, to increase the body of knowledge on this topic is vital. It is essential to conduct research to collect evidence for or against the assumption that remittances flowing through the formal sector helps increase the development of the financial sector. Further, it must be investigated whether this process translates to higher economic growth. There is currently only one paper on Mexico that attempts to look at this. ${ }^{63}$

There is an extreme lack of data on the remittance channel decision. Much more longitudinal data, spanning many years must be collected to fill this gap. This of course suggests that more time is needed to know the real situation, as goodquality remittance data has only become available in the last 10 years. In many countries, good data collection is a recent phenomenon, while in others remittance data is still hard to come by.

${ }^{63}$ Demirgüç-Kunt Asli, Lopez-Cordova Ernesto, Martinez Peria Maria Soledad, Woodruff Christopher. Remittances and Banking Services: Evidence from Mexico. (2007) Washington, D.C: World Bank, Development Research Group. 


\subsubsection{Migration and remittance effects}

Longitudinal studies with household follow-up over a significant period would be an excellent contribution to the library of data available for analyses, specifically in terms of substantiating the effects of migration and remittances on affected households. Most research on the effects of migration and remittances singles out specific aspects (usually economic) for study, but it is imperative that more research looks at combined effects of migration and remittances on economic and social indicators. Only when such data has been made available will it be possible to see the true costs and benefits of migration, and only then can sound policy be formed to increase the positive effects while mitigating the negative ones.

All in all, the research presented in this dissertation has enriched our understanding of decisions to migrate, to remit and to remit through certain channels and explored the effect of remittances on the health care behaviour of sending households. The empirical analyses and theoretical explorations, however, have also illustrated that sophisticated migration research still leaves many interesting questions unanswered or answered in an inconclusive way. The future availability of new and more encompassing databases and the constant progress that the academic migration debate is producing, inspires us to keep involved in new research projects on the many migration issues that need more clarification. Our engagement in this research area is not only motivated by the genuine desire to better understand, but also by the wish to contribute to more comprehensive policy initiatives that aim at stimulating the positive impact of migration for the sending - often relatively poor - countries, for the receiving countries and for the migrating individuals and families. 


\subsection{References}

Carling, J. (2008) "The Determinants of Migrant Remittances", Oxford Review of Economic Policy.

Claessens, S. (2006). "Access to Financial Services: A Review of the Issues and Public Policy Objectives." World Bank Research Observer 21: 207-240.

Demirgüç-Kunt, López Córdova, Martinez Pería and Woodruff (2008) "Remittances and banking services: evidence from Mexico," Working paper.

Hernándes-Coss, R. (2005) “ The U.S.-Mexico Remittance Corridor: Lessons on Shifting from Informal to Formal Transfer Systems", World Bank Working Paper 47.

Rios-Avila, F. and E. Schlarb (2008). "Bank Account and Savings - The Impact of Remittances and Migration: A Case Study of Moldova." Kiel Advanced Studies Working Paper 448.

Sander, C., D. Nistor, et al. (2005). Migrant Remittances and the Financial Market in Moldova. BASIS CRSP, Madison: University of Wisconsin 


\title{
Monetaire Middelen en Mobiliteit: Migratie en Geldoverboekingen
}

\author{
Nederlandse Samenvatting
}

\section{Samenvatting}

Dit proefschrift richt zich op economische migratieprocessen en de consequenties hiervan. In het bijzonder wordt aandacht besteed aan geldoverboekingen ten gevolge van economische migratie, en de consequenties van het zenden en ontvangen van deze overboekingen voor de migranten en hun thuislanden. Door de focus op economische migratie gaan we in dit proefschrift grotendeels voorbij aan vluchtelingenstromen en gedwongen migratie. Echter, migratiestromen bestaan nog steeds voor het grootste gedeelte uit mensen die migreren vanuit economische overwegingen. Deze economische migratie kan zich uiteindelijk ook manifesteren in de vorm van gezinshereniging, huwelijksmigratie en andere vormen van economische migratie, zoals arbeidsmigratie.

Om inzicht te krijgen in economische migratie en de geldoverboekingen die hieruit voortvloeien, zal een reeks van factoren die ten grondslag ligt aan deze processen aan bod komen in dit proefschrift. Door middel van case studies, waarin theoretische kaders en concepten getoetst worden, worden in dit proefschrift de verklarende factoren van migratie processen en geldoverboekingen geanalyseerd. Op deze manier wordt de bruikbaarheid en toepasbaarheid van deze factoren in het voorspellen van toekomstige migratie stromen en trends in geldoverboekingen aangetoond.

Dit proefschrift richt zich voornamelijk op de geldoverboekingen van migranten. Migratie als geheel proces wordt echter ook besproken, met name in de eerste twee hoofdstukken. In hoofdstuk twee wordt gekeken naar de determinanten van economische migratie. Dit hoofdstuk richt zich vooral op de vraag waarom mensen migreren en welke factoren een rol spelen in de mogelijkheden van mensen om te migreren. Een innovatieve benadering ten opzichte van migratiepatronen is gekozen door het toepassen van het Welzijns Pentagon theoretisch kader. Het Welzijns Pentagon, wanneer toegepast op migratie, brengt de potentiële migrant toegang tot de vijf verschillende delen van het Welzijns Pentagon, zijnde de financiële markt, de staat, familie, sociale netwerken en lidmaatschappen van instituties, in kaart. De toegang tot deze vijf factoren wordt gebruikt om te verklaren in hoeverre personen de mogelijkheid hebben om te 
migreren als ze dit wensen. Het theoretische kader van het Welzijns Pentagon wordt vervolgens getoetst in Albanië en Moldavië, twee landen gekenmerkt door hoge emigratie cijfers. In beide gevallen blijkt het Welzijns Pentagon een goed theoretisch model om economische migratie te voorspellen. Uit de analyse blijkt dat niet alleen toegang tot monetaire middelen een belangrijke voorspeller van migratie is, maar dat alle factoren van het Welzijn Pentagon een belangrijke rol spelen in het migratieproces.

In de volgende hoofdstukken worden de financiële overboekingen besproken die migranten doen naar hun thuisland nadat ze zijn gemigreerd. Hoofdstuk drie richt zicht op de determinanten van geldoverboekingen, hoe geldoverboekingen over het algemeen gemeten worden, en in hoeverre deze meetinstrumenten geschikt zijn voor huidige geldoverboekingen. Geldoverboekingen naar familie in het thuisland komen vaak voor na migratie, maar de factoren die ten grondslag liggen aan deze geldoverboekingen zijn nog niet voldoende onderzocht. Om deze factoren te onderzoeken wordt allereerst naar bestaande theorieën gekeken die verklaren waarom mensen geld naar huis sturen, zoals altruïsme theorieën en theorieën met betrekking tot zelfinteresse. Vervolgens worden deze theorieën getoetst met data uit Albanië en Moldavië. Dit onderzoek toont aan hoe moeilijk het is om de motivaties van migranten empirisch te toetsen, en geeft een verklaring voor het feit dat voorafgaande studies vaak wisselende resultaten op hebben geleverd. Dit hoofdstuk eindigt daarom met een kritische noot wat betreft het empirisch toetsen en het interpreteren van de factoren die ten grondslag liggen aan geldoverboekingen van migranten.

In hoofdstuk vier wordt gekeken naar hoe migranten geld overboeken zodra zij besloten hebben geld naar huis te sturen. Dit hoofdstuk gaat over de keuze van een migrant voor een bepaalde wijze van geld sturen, en welke factoren hierbij een rol spelen. Het is belangrijk om de wijzen van geld sturen te onderzoeken, omdat geld gestuurd wordt naar alle delen van de wereld, en dus naar gebieden die sterk variëren wat betreft financiële infrastructuur. Hierdoor zijn de kanalen die migranten gebruiken om geld te sturen ook variabel. Om de impact van migratie en geldoverboekingen op ontwikkelingsprocessen in het thuisland te vergroten is het belangrijk om te weten hoe het voor migranten makkelijker, sneller en goedkoper kan worden gemaakt om geld te sturen. Ook is er een groeiende lobby van regeringen en international organisaties, zoals het Internationaal Monetair Fonds (IMF) en de Wereld Bank, om geldoverboekingen meer door formele kanalen, zoals banken, te laten gaan. Hierdoor ontstaat er een verscherpte controle op internationale geldstromen, en wordt de financiële sector in het ontvangende land versterkt. 
In hoofdstuk 4 wordt Moldavië opnieuw als een case studie gebruikt. De motivaties voor Moldavische migranten om te kiezen voor een bepaalde manier van geld overboeken, zoals kosten, snelheid, veiligheid, toegang, bekendheid met de wijze van overboeking, en vertrouwen dat de migrant heeft in de overboeking, worden empirisch onderzocht. Verder worden verklarende variabelen meegenomen in de analyse. Er wordt onder andere gekeken naar het land waar migranten het geld naar toe sturen, maar ook naar persoonlijke kenmerken van migranten, zoals hun educatie niveau en migratie geschiedenis. De resultaten laten zien dat ongeveer de helft van de Moldavische migranten informele kanalen gebruikt om geld naar hun thuisland te sturen. De migranten die informele kanalen gebruiken hebben een grotere kans om in rijkere (vooral EU) landen te wonen, om illegaal te zijn, om langer dan een jaar weg te zijn uit hun thuisland, om geen bankrekening te hebben, en om vooral op de kosten te letten bij het kiezen van de wijze van overboeking. Een aantal van deze determinanten kunnen aangepakt worden met behulp van passend beleid. Andere factoren reflecteren echter geldoverboekingen die voortkomen uit bepaalde migratiepatronen, zoals seizoen- of onregelmatige migratie, welke moeilijk te beïnvloeden zijn.

Hoofdstuk vijf richt zich op geldoverboekingen van migranten vanuit Nederland, en opnieuw wordt gekeken naar de keuze voor bepaalde wijzen van geldoverboeken. Echter, dit hoofdstuk richt zich met name op de vraag hoe de integratie van de migrant in het gastland de keuze voor de wijze van geldoverboeken beïnvloedt en welke andere factoren hierbij van belang zijn. De groepen die onderzocht worden zijn Turkse, Marokkaanse, Surinaamse, Antilliaanse, Ghanese en Somalische bevolkingsgroepen in Nederland. De analyses geven een gemixt resultaat voor de hypothese dat migranten die beter geïntegreerd zijn in de Nederlandse samenleving vaker geld sturen door formele kanalen. In plaats van de mate van integratie spelen juist beleid en instituties een belangrijke rol voor Nederlandse migranten. Landen die gebaat zijn bij het ontvangen van geldoverboekingen en geïnvesteerd hebben in de benodigde financiële infrastructuur, zoals Turkije, ontvangen meer geldoverboekingen door deze formele kanalen dan landen die geen financiële infrastructuur opgezet hebben.

Vanuit de determinanten van migratie, via de determinanten van geldoverboekingen, naar de wijzen van geld overmaken, gaat hoofdstuk zes over de effecten van migratie op de landen die het geld ontvangen. Wanneer de geldoverboekingen hun bestemming bereiken, kunnen er verschillende effecten optreden in de huishoudens die het geld ontvangen. In dit hoofdstuk wordt weer teruggegrepen op Moldavië als case studie om te bepalen wat het effect is van geldoverboekingen, in dit geval op gezondheidszorguitgaven binnen het ontvangende huishouden. Uitgaven aan gezondheidszorg is een belangrijke indicator voor de ontwikkelingsimpact die geldoverboekingen kunnen hebben. 
Echter, deze indicator is niet vaak onderzocht in studies over de link tussen migratie en ontwikkeling. Een vergelijking wordt gemaakt tussen migranten en niet-migranten huishoudens om te bepalen wat het verschil is in gezondheidszorguitgaven tussen deze twee typen huishoudens. Verrassend is dat huishoudens die geen geldoverboekingen ontvangen van familieleden in het buitenland meer geld uitgeven aan gezondheidszorg, dan huishoudens die wel geldoverboekingen ontvangen.

Dit proefschrift levert een bijdrage aan bestaand onderzoek naar economische migratie en geldoverboekingen. Ieder hoofdstuk bevat een kritische analyse van de algemeen aanvaarde benaderingen van migratie en geldoverboeking theorieën, en toetst de toepasbaarheid van deze benaderingen op de case studies geselecteerd voor dit proefschrift. In hoofdstuk twee wordt een nieuw en innovatief kader geïntroduceerd om de oorzaken van migratie te beschrijven en te verklaren. Vervolgens wordt dit theoretisch kader getoetst. Het kader verschaft een uitbreiding van bestaande literatuur en biedt een nieuw perspectief ten opzichte van motivaties voor migratie. In hoofdstuk drie wordt kritisch gekeken naar bestaande literatuur waarin de motivaties voor geldoverboekingen empirisch worden getoetst, en wordt de betrouwbaarheid van de resultaten van deze literatuur bediscussieerd. Hoofdstuk vier en vijf bieden een aanvulling tot de schaarse literatuur over hoe migranten geld overboeken naar hun thuisland. Hoewel het onderzoek naar geldoverboekingen van migranten gestegen is de laatste jaren, is er nog geen systematisch onderzoek verricht naar de verschillende manieren van geld overboeken en de impact van deze verschillende manieren op ontwikkelingsprocessen in het ontvangende land. Ten slotte wordt in hoofdstuk zes het effect van migratie en geldoverboekingen op uitgaven voor gezondheidszorg onderzocht. Dit is een relatie waar nog niet voldoende aandacht aan is besteed in eerdere studies die keken naar het potentiële ontwikkelingseffect van migratie.

De hoofdstukken in dit proefschrift zijn geschreven als aparte artikelen en de meesten van hen zijn inmiddels gepubliceerd, of in behandeling ten behoeve van publicatie, in wetenschappelijke vaktijdschriften. Dit betekent dat sommige delen van de hoofdstukken enige overlap kunnen vertonen. 


\section{Curriculum Vitae}

Melissa Siegel was born April 8, 1981 in Illinois, United States. She received her Bachelor's degree in Economics from the College of Charleston, United States in 2003. During her Bachelors Degree she studied in both The Netherlands and Sweden. She then went on to complete two Master's degrees at Utrecht University in the Netherlands in Law and Economics (MSc) in 2004 and Policy and Organization (MA) in 2005.

Melissa currently works as a Post Doctoral Researcher and Migration Studies Program Manager at the Maastricht Graduate School of Governance where she manages several migration research projects and coordinates the Migration Studies Specialization.

She previously worked for Utrecht School of Economics, Utrecht University as a Junior Researcher before starting her PhD in 2005 and working as a Research Fellow at the Maastricht Graduate School of Governance. During her PhD, she had a Visiting Research Fellowship at The Wiener Center for Social Policy at the Kennedy School of Government, Harvard University and spent a short visiting period at the Kiel Institute for the World Economy. She has worked on projects for the Dutch Ministry of Social Affairs, the Dutch Ministry of Finance, the Dutch Ministry of Foreign Affairs and Oxfam Novib. She has conducted research for the Dutch Ministry of Finance on money laundering and the remittance corridor between The Netherlands and Suriname. She has recently finished the remittance corridor study between the Netherlands and Afghanistan for the Ministry of Foreign Affairs and is also currently managing the IS Academy on Migration and Development for the Ministry. 


\section{Maastricht Graduate School of Governance Dissertation Series}

Jessica S. Hagen-Zanker

Modest expectations: Causes and effects of migration on migrant households in source countries

Maastricht Graduate School of Governance Dissertation Series, nr. 5 (2010)

Mirtha R. Muniz Castillo

Human Development and Autonomy in Project Aid: Experiences from four bilateral projects in Nicaragua and El Salvador

Maastricht Graduate School of Governance Dissertation Series, nr. 4 (2009)

Christiane Arndt

Governance Indicators

Maastricht Graduate School of Governance Dissertation Series, nr. 3 (2009)

Britta Augsburg

Microfinance - Greater Good or Lesser Evil?

Maastricht Graduate School of Governance Dissertation Series, nr. 2 (2009)

Geranda Notten

Measuring and Managing Poverty Risks

Maastricht Graduate School of Governance Dissertation Series, nr. 1 (2008)

www.maastrichtuniversity.nl/governance 